\title{
MOTIVOS QUE LEVAM À ESCOLHA DA ESTERILIZAÇÃO ENTRE MULHERES USUÁRIAS DO SUS - FEIRA DE SANTANA - BA
}

\section{NEUZA TEIXEIRA DE CARVALHO}

Tese apresentada ao Departamento de Práticas de Saúde Pública da Faculdade de Saúde Pública da Universidade de São Paulo para obtenção do Título de Doutor.

Área de concentração: Serviços de Saúde Pública ORIENTADOR: Prof. Dr. Paulo Antonio de Carvalho Fortes.

São Paulo

2003 


\section{DEDICATÓRIA}

A minha mãe, Antonia Teixeira de Carvalho, pelo afeto, apoio e compreensão que me deram suporte para realização deste trabalho.

Ao meu pai, Lelino Avelino de Carvalho, que partiu para outra dimensão durante a realização deste trabalho e que sempre estará comigo. 


\section{AGRADECIMENTOS}

À Universidade Estadual de Feira de Santana, em especial à Reitora Prof ${ }^{a}$ Anaci Bispo Paim, por ter proporcionado a oportunidade de realização deste doutorado.

À Profa. Elma Lígia Pires Leal Liberal, que muito me incentivou para participar do curso, oferecendo-me todo apoio.

À Prof ${ }^{a} D r^{a}$. Maria Lúcia Silva Servo, diretora do Departamento de Saúde, pela imensa compreensão e amizade, proporcionando- me tranqüilidade durante todo o tempo de realização do curso.

Ao Prof. Dr. Paulo Antonio Carvalho Fortes, meu orientador, por ter investido em mim. $\mathrm{O}$ seu apoio, compreensão e amizade, contribuíram substancialmente, para o meu crescimento.

A todos os professores que participaram do curso, pela cordialidade e incentivo, em especial a $\operatorname{Prof}^{a} \mathrm{Dr}^{a}$ Márcia Furquim de Almeida, que sempre colaborou e me incentivou para realização desse estudo, e a Prof ${ }^{a}$. Dr ${ }^{a}$. Evilin Naked de Castro Sá pelas palavras de carinho e estímulo.

À Prof ${ }^{2}$. Dr ${ }^{2}$. Ana Cristina D'Andretta Tanaka e Prof ${ }^{a}$. Dr ${ }^{2}$.Isilia Aparecida Silva, pelas sugestões valiosas, quando da qualificação.

À Prof ${ }^{a}$. Évila Oliveira, pela cuidadosa revisão ortográfica.

As queridas Letícia M. Teixeira Rocha, Nora Ney Alves Santos e Lúcia $H$. Lessa e Silva, irmãs que me "seguraram" nos momentos mais difíceis.

Aos meus queridos tios Maria Célia Teixeira M. Santos e William Moura Santos, pelo estimulo, afeto e suporte emocional em São Paulo.

A colega e amiga Robéria Lúcia Prates Santos, pelo estímulo muito próprio, e companheirismo nos deslocamentos para São Paulo. 
A Erenilde Marques Cerqueira, pela amizade, disponibilidade, e bom humor, incansável na tarefa de levantar o meu "astral” nos momentos difíceis.

A Maria Margarethe Pizzani, amiga que abriu sua casa e seu coração em São Paulo, pela inesquecível ajuda no momento tão estressante da qualificação.

Às queridas Elisangela Souza e Tânia Lago, pelo profissionalismo, constante colaboração, e disposição em me auxiliar na procura de soluções.

$\mathrm{Na}$ pessoa de Marivaldina Bulcão, agradeço a todas as bibliotecárias da Biblioteca Julieta Carteado da UEFS, que sempre pude contar por ocasião da busca bibliográfica. E a Graça Maria Dutra Simões, pela correção da revisão da bibliografia.

A direção do Hospital Inácia Pinto - Hospital da Mulher, e do Hospital MaterDei por ter permitido acesso às enfermarias, para o contato com as mulheres.

Ao grupo de Agentes Comunitários de Saúde da Região 21 do Pacs, por toda ajuda que dispensou para a localização das mulheres na comunidade, e pela alegria com que me receberam.

As Enfermeira Vera Gardênia Leite, da Unidade de Saúde do Feira X, Rosana de Melo, do Hospital Mater Dei, e ao grupo de enfermagem da Enfermaria B do Hospital da Mulher pela acolhida e inestimável ajuda.

A todas as mulheres entrevistadas, sujeitos desse estudo, pela colaboração, e por me receber em suas residências com muito carinho.

Aos funcionários da Biblioteca de Saúde pública da USP, em especial a bibliotecária Maria Lúcia Ferraz, pela gentileza e disponibilidade.

As colegas da disciplina Saúde da Mulher Criança e Adolescente I, pela compreensão da ausência necessária.

Ao funcionário Nivaldo de Assis Silva Filho, pela solidariedade e atenção dispensada quando da reprodução deste trabalho. 


\section{RESUMO}

CARVALHO, N. T. Motivos que levam à escolha da esterilização entre mulheres usuárias do SUS - Feira de Santana - BA. São Paulo, 2002. [Tese de Doutorado Faculdade de Saúde Pública da Universidade de São Paulo].

Objetivo. Conhecer os motivos que levam mulheres residentes em Feira de Santana BA a buscar a esterilização como método contraceptivo, ao tempo em que se pretende avaliar informações dessas mulheres esterilizadas a respeito das implicações da esterilização. Método. Estudo qualitativo, utilizando a técnica de entrevista semiestruturada, com vinte mulheres. As entrevistas, realizadas a partir de perguntas norteadoras, foram gravadas e transcritas. Procedeu-se a uma análise, a qual foi realizada segundo a técnica de análise de conteúdo. Resultados. Dentre os motivos apontados pelas mulheres para escolha da esterilização estão a dificuldade no uso da pílula, rejeição ao DIU, inadequação com outros métodos, satisfação com a prole por ter atingido o número desejado de filhos e situação socioeconômica. A dificuldade na utilização de métodos reversíveis é baseada em representações formadas a partir de informações recebidas nos serviços de saúde e, principalmente, no meio social e vivências anteriores com os métodos. A falta de informação sobre esterilização é uma constante entre as mulheres entrevistadas, assim como sobre métodos contraceptivos em geral, o que dificulta seu uso. Conclusões. A esterilização como método contraceptivo entre mulheres de baixa renda não se traduz, na maioria das vezes, em uma escolha ou opção, mas em uma absoluta falta de escolha a elas imposta pelas circunstâncias vividas. Os resultados alcançados apontam para a necessidade de se ter serviços de saúde melhor estruturados e de se promover o desenvolvimento de ações educativas em saúde reprodutiva, proporcionando assim a escolha livre e informada sobre a regulação da fecundidade.

Descritores. Esterilização feminina. Fecundidade. Contracepção. Planejamento familiar. Ligadura tubária. Métodos reversíveis. 


\section{SUMMARY}

CARVALHO, N. T. Reasons that guide women who use the public medical service SUS - Feira de Santana - BA to the choice of sterilization. São Paulo, 2002. [Doctorate Thesis - Faculdade de Saúde Pública da Universidade de São Paulo].

Objective. The research aims at knowing the reasons that guide resident women of Feira de Santana City, in the State of Bahia, Brazil, to choose sterilization as a contraceptive method, and, in addition, aims at making an evaluation of the comments among them concerning the sterilization consequences. Method. Qualitative research, using the semistructured interview technic, with twenty women. The interviews, made upon directed questions, were recorded and transcript. Then, an analysis was made according to the content technic analysis. Results. Among the reasons pointed out by the women for choosing a sterilization procedure are the difficulty in the use of pills, rejection to the IUD, inadequacy with other methods, desired number of sons already achieved and their particular socioeconomical situation. The difficulty in the use of reversible methods is based upon conclusions that were taken from information collected in several medical service places and, mainly, in their neighborhood and experiences with contraceptive methods. Lack of information on sterilization as well as on contraceptive methods in general is frequent among the women who took part of the research, thus creating difficulties to their use. Conclusions. Sterilization as a contraceptive method among women of low purchasing power doesn't mean, in most cases, just a choice or an option, but a true lack of choice possibility due to their livelihood. The results point out to the need of a better-organized public medical service and the promotion of educational actions in reproductive health, in order to permit a well-informed and free choice of a desired fecundity planning.

Descriptors: Women's sterilization. Fecundity. Contraception. Family planning. Tubal sterilization. Reversible methods. 


\section{ÍNDICE}

1 INTRODUÇÃO .................................................................................................. 1

1.1 Queda da Fecundidade e Esterilização ................................................................. 4

1.2 História e Política Pública do Planejamento ………………………………........ 8

1.3 Aspectos Jurídicos da Esterilização ……………………………………..... 16

1.4 A mulher e a Cultura da Esterilização............................................................ 20

1.5 Esterilização por Ligadura Tubária .............................................................. 22

1.6 As Opções de Métodos Contraceptivos ........................................................ 25

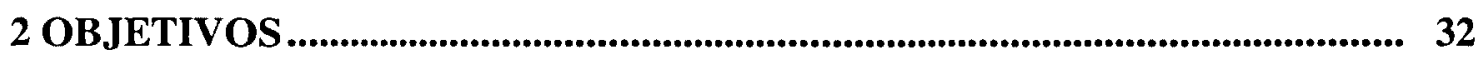

3 PROCEDIMENTOS METODOLÓGICOS …............................................... 33

3.1 Estratégia de Pesquisa ....................................................................................... 33

3.2 As representações Sociais ........................................................................ 34

3.3 Cenário do Estudo ................................................................................ 40

3.4 Sujeitos do Estudo ................................................................................... 41

3.5 Instrumento de Pesquisa e Coleta de Informações............................................ 43

3.6 Procedimentos de Análise ............................................................................... 45

4 MOTIVOS QUE LEVARAM A ESCOLHA DA ESTERILIZAÇÃO.............. 49

4.1 Dificuldade no Uso da Pílula ........................................................................ 49

4.2 Medo do DIU ……….................................................................... 58

4.3 Dificuldade com Outros Métodos ................................................................. 62

4.4 Satisfação com a Prole …........................................................................... 68

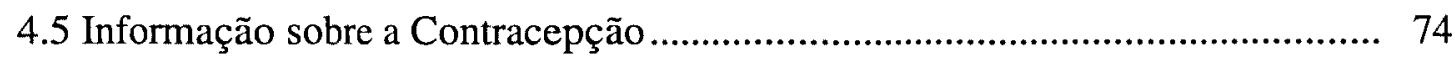

4.6 Informação sobre Esterilização ...................................................................... 86

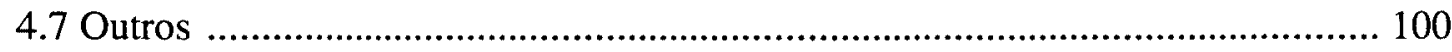

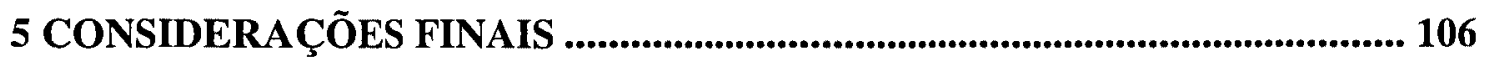




\section{ANEXOS}

Anexo 1 - Ficha de Identificação................................................................. A2

Anexo 2 - Termo de responsabilidade do pesquisador...................................... A3

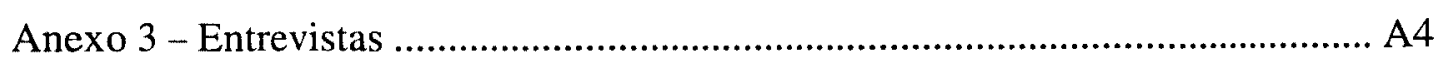

Anexo 4 - Unidade de Registro categorias e temas construídos a partir das entrevistas ........................................................................ 25

Anexo 5-Temas e Categorias construídos a partir das unidades de registro .........A51 


\section{INTRODUÇÃO}

O planejamento familiar é uma política de saúde que prevê ações médicas sociais com o objetivo de promover a saúde do binômio mãe-filho, a qualidade de vida familiar, a saúde reprodutiva da mulher e o intervalo entre uma concepção e outra. Um dos objetivos básicos do planejamento familiar é oferecer aos casais a possibilidade de decidir sobre o número de filhos que terão. Entretanto, a tomada de decisão é feita de forma mais consciente quando há o conhecimento respaldado em informações técnicas oferecidas pelos profissionais de saúde.

Por planificação familiar entende-se como, um modo de pensar e viver adotado voluntariamente por pessoas e casais baseando-se em conhecimentos, atitudes e decisões, tomadas no sentido responsável, a fim de promover a saúde e o bem-estar e contribuir assim eficazmente para o desenvolvimento social do país. Neste contexto, a planificação familiar supõe conhecimentos e ações, que ajudam a pessoa a alcançar os objetivos fixados a respeito de sua família para melhorar suas condições de vida. Supõe, também, a difusão de informações pertinentes à educação do povo e a organização de serviços sanitários, que permitam às pessoas e aos casais, independentemente de sua situação econômica e social, adotar decisões com conhecimento de causa. (OMS 1971).

Em diversos países o planejamento familiar já é adotado. No Brasil é uma prática comum nas classes altas e médias. Todavia é ainda preciso que também se ofereçam aos casais de baixa renda os meios necessários para planejar suas famílias.

O processo decisório é posterior à informação e ao conhecimento. Não pode haver decisão sem conhecimento de opções. Portanto, para exercer o direito de decidir sobre a prole o casal deve ter acesso a informações (CARNEIRO e RODRIGUES 1987). A oferta de informações sobre os diferentes métodos de contracepção é uma atividade da equipe de saúde que deverá ajudar o casal a acolher o método mais adequado, o momento mais apropriado para gravidez, definir o tamanho da família e prevenir situações de alto risco. As tarefas educativas devem ser realizadas por todos os profissionais que atuem nos serviços de atendimento à 
saúde da mulher. Sem dúvida este investimento, em longo prazo, é que permitirá aos casais mais segurança na tomada de decisões.

Para que haja eficiência de qualquer método contraceptivo é necessário que a escolha seja livre, mas com pleno conhecimento de todos as suas conseqüências, sob pena de comprometer sua eficácia e gerar possíveis arrependimentos. Para ZEIGEL (1985), o maior perigo de fracasso, talvez, seja a tentativa da equipe de saúde em influenciar a decisão do cliente com base em seus próprios valores. O principal problema ético encontrado no planejamento familiar, segundo FAUNDES e HARDY (1999), é a possibilidade que o médico tem de impor este ou aquele método, seja por ação direta, seja por omissão de informar e oferecer métodos que a mulher ou o homem poderia preferir a aqueles que o médico recomenda.

As falhas que se registram nos métodos anticoncepcionais são, geralmente, causadas por defeitos dos próprios métodos, erros dos usuários, ou associação desses dois aspectos. A irregularidade do uso de um método constitui-se na principal razão de falha por erro humano. Outro motivo para a falha é o uso inadequado da técnica empregada. Isso pode advir de um conhecimento inadequado de anatomia, fisiologia de reprodução, compreensão incorreta do método e seu modo de ação ou dificuldade para dominar a técnica.

Nos países em que a esterilização feminina apresenta alta prevalência, além de ser de extrema importância conhecer os motivos que levam à adoção desse método, é também importante saber se a idade da mulher, à época da cirurgia, vem diminuindo, assim como se a esterilização tem sido realizada prioritariamente durante o parto do último filho ou não (BEMFAM/ DHS/MACRO 1997).

A significativa popularidade da ligadura de trompas no Brasil é incontestável. Entretanto, não existem muitos estudos que expliquem esta preferência. Para FAUNDES e cols. (1998), o que se argumenta é que este recurso anticonceptivo esteja associado ao fato de ter realização acessível, seja juntamente com cesáreas pagas pelo Sistema Único de Saúde (SUS), ou como parte de campanhas eleitorais de candidatos a cargos eletivos políticos. 
Já que a esterilização está sendo adotada, substancialmente, apresentando, inclusive, percentuais mais altos quando o nível de escolaridade é menor, e, por se tratar de uma prática contraceptiva recente, na perspectiva da preferência das mulheres por esse método, pretendemos com este estudo identificar os motivos, que levam a mulher a preferir a esterilização como método anticoncepcional e avaliar as informações que têm a respeito da esterilização.

Nosso estudo pretende, portanto, conhecer os motivos pelos quais mulheres, residentes na cidade de Feira de Santana/BA, recorreram ao procedimento de esterilização por ligadura tubárea em serviços do Sistema Único de Saúde.

A realidade em Feira de Santana, cidade situada no semi-árido baiano, não difere muito da situação nacional, podendo, dessa forma, inseri-la como parte dos dados da região nordeste. As unidades básicas, em sua maioria, desenvolvem programas de planejamento familiar no conjunto de ações de atuação na Saúde da Mulher. Entretanto, em nossa experiência de atuação junto ao pré-natal, quando acompanhamos estágio, dos alunos do curso de enfermagem, notamos que a maioria das gestantes não observa o período mínimo de dois anos para voltar a engravidar. Muitas delas relatam ter engravidado sem desejar, e há ainda, aquelas que engravidam mesmo usando algum método contraceptivo. Quando orientadas a buscar os serviços de planejamento familiar a resposta, em sua grande maioria, é o desejo de realizar laqueadura de trompas, mesmo aquelas muito jovens, e com número pequeno de filhos e sem indicação clínica para a esterilização.Também se registraram casos de gestantes com indicação para laqueadura, mas que não conseguem realizá-la, embora deseje.

Há indícios, nessas observações, de que os serviços de planejamento familiar não estão dando respostas à necessidade de saúde reprodutiva das mulheres que deles necessitam, tanto do pronto de vista da acessibilidade ou da metodologia de informação e educação.

A partir destes registros levantamos os seguintes questionamentos:

- As mulheres que escolhem a esterilização como método anticoncepcional conhecem outros métodos, já fizeram uso e têm informações necessárias a respeito do método escolhido? 
- Ao escolher a esterilização a mulher é informada dos aspectos negativos que envolvem esta escolha

Optar pela esterilização, como método contraceptivo, é uma decisão que qualquer mulher pode tomar, e que consideramos justa. Todavia é imperativo que ela tenha o direito à informação necessária, tanto no tange aos riscos e efeitos colaterais, quanto às vantagens de cada método. Assim procedendo, fica resguardado o direito de exercer a sua cidadania com relação ao número de filhos que deseja ter, e à sua saúde reprodutiva.

Acreditamos que a contribuição deste estudo, ao identificarmos os fatores que levam a mulher a optar pela esterilização, seja oferecer subsídios aos administradores de saúde visando à implantação do PAISM - Programa de Assistência Integral à Saúde da Mulher, promovendo mudanças benéficas na forma de oferta de esterilização, principalmente a nível regional. Poderá também contribuir com equipes de saúde que orientam mulheres nos serviços de Planejamento Familiar, como um meio de melhorar a qualidade da informação para escolha dos métodos anticoncepcionais.

Duas razões, acreditamos, justificam a realização deste estudo: a prática indiscriminada da esterilização feminina, principalmente em mulheres jovens, e a falta de assistência e orientação na área de contracepção. Fatores que, reunidos, podem redundar em riscos à saúde da mulher.

\subsection{Queda da Fecundidade e Esterilização}

A queda da fecundidade é uma realidade para a maioria dos países. Considerando-se esse fenômeno como um marco do século XX.

No intuito de procurar explicações para o declínio da mortalidade e fecundidade, fenômeno que vem ocorrendo desde o final do século XIX, nos países europeus é que surgiu a Teoria da Transição Demográfica. Esta teoria difunde a idéia da passagem de um ponto de estabilidade demográfica a outro, também, de estabilidade. O primeiro ponto seria caracterizado como de alta mortalidade e 
fecundidade e, o segundo, como de baixa mortalidade e fecundidade. O período precedente ao da "desestabilização" seria a fase em que seriam buscadas as dimensões explicativas do fenômeno (PATARRA e CARVALHO, 1988).

Outra teoria, que tenta explicar o fenômeno da queda da fecundidade, é a chamada Teoria da Difusão, segundo a qual o peso atribuído, às determinações sócio-econômicas, diminui e vincula-se à idéia da difusão de ideologias de camadas mais elevadas da sociedade para outras (MARTINS 1999).

Dos fatores apontados para esta difusão destacam-se a socialização dos meios de comunicação de massa e o rápido processo de urbanização da população brasileira a partir da década de 60 .

MORELL (1992), considera que três fatores são determinantes na diminuição da fecundidade: a difusão da necessidade de controle do tamanho da família, a incidência de aborto provocado e o acesso a métodos anticoncepcionais (MACs) tecnologicamente eficazes.

De acordo com ARILHA (2000), a fecundidade, no Brasil, reduziu consideravelmente de 4,5 filhos em 1980 para 3,5 em 1984 chegando a 2,5 em 1991. Ocorre, no entanto que tal redução foi obtida pelo elevado uso de esterilização feminina e da pílula utilizada no Brasil respectivamente por $44 \%$ e $41 \%$ das mulheres unidas de 15 a 54 anos.

Segundo dados da Pesquisa Nacional sobre Demografia e Saúde (PNDS), a taxa de fecundidade nacional se mantém em 2,5. Todavia na região nordeste, a taxa de fecundidade total apresenta uma ligeira oscilação com relação à média nacional chegando a 3,1 filhos por mulher ( BEMFAM/ DSH/ MACRO 1997). Para BERQUÓ (1993), a taxa de esterilização entre mulheres unidas, na região nordeste do país cresceu 47,2\% em 1986 para 62,9\% em 1991, em detrimento da pílula que teve a sua presença reduzida de $32,1 \%$ para $22,0 \%$. Para a autora, na região mais pobre do país fechou-se mais ainda o leque de alternativas contraceptivas.

Ao lado da queda da fecundidade, que ocorre em todo o país, com leves oscilações regionais, pelas diferentes classes sociais, e tanto na zona urbana quanto da zona rural encontramos a alta prevalência da opção pela esterilização entre a população feminina. No início dos anos 90 chegou-se, mesmo, a falar em 
"esterilização em massa" das mulheres brasileiras. E poucas não foram as denúncias veiculadas pela mídia de casos de esterilização indiscriminada, suscitando, até, instauração de comissões parlamentares de inquérito em diferentes níveis para apurar possíveis abusos (SEMPREVIVA 1994).

Em Feira de Santana e região, a partir da década de 80, a cada campanha eleitoral é desencadeada uma oferta indiscriminada de esterilização, patrocinada por concorrentes a cargos eletivos, fato esse observável por toda população.

A esterilização feminina é o método anticoncepcional mais usado pelas mulheres brasileiras. Em 1986, 27,0\% de todas as mulheres em união sexual de 15 a 44 anos estavam esterilizadas (Arruda et al 1987 Apud VIEIRA 1998). A última pesquisa nacional sobre demografia e saúde de 1996, mostra uma prevalência de $40,0 \%$ de esterilização para mulheres unidas de 15 a 49 anos (BEMFAM / DHS / MACRO, 1997). Na região nordeste, também cresceu o número de esterilização entre 1986 e 1991; segundo dados da BEMFAM (1991) em 1986, as mulheres esterilizadas na zona urbana perfaziam um total de 43,4\%. Fato que, em 1991, já representava $65,4 \%$. Foi observado, também, um aumento significativo nas mulheres residentes na zona rural, aumentando de 32,3\% em 1986 para 60,1\% em 1991 .

A grande preferência pela esterilização, tem sido apontada por alguns autores como uma resposta das mulheres à falta de alternativas anticoncepcionais e aos perigos do aborto provocado (BERQUÓ 1989).

O aumento da gravidez na adolescência, nos últimos anos, leva a mulher brasileira a iniciar sua vida reprodutiva muito cedo e, muitas vezes, esta é encerrada através da esterilização em idades que, também, podem ser consideradas muito precoces. Os dados divulgados pela PNDS demonstram que 21,0\% das mulheres recorreram à esterilização com menos de 25 anos, 36,6\% entre 25 e 29 anos, 27,9\% entre 30 e 34 anos. A idade média para esta realização é de 28,9 anos.(BEMFAM /DSH/ MACRO 1997)

A esterilização é realizada, na grande maioria dos casos $(74,0 \%)$, por ocasião do parto. Nos países latino-americanos que dispõem deste tipo de informação sabe-se que, efetivamente, uma proporção elevada de esterilização ocorre por ocasião do último parto. Este é o caso, por exemplo, para o México em 1987, e República 
Dominicana em 1991. Mas o que diferencia o Brasil desses países é a prática da cesariana. Enquanto que na República Dominicana, metade das esterilizações ocorre por cesárea, no Brasil a grande maioria, quatro em cada cinco, è procedida durante a cesariana (BEMFAM/ DSH/ MACRO 1997).

Segundo MINELLA (1998), os dados sobre o tipo de esterilização, em termos gerais, demonstraram que predomina a laparotomia ampla (feita durante cesariana). $O$ alto índice representado pela laparotomia ampla realizada durante cesariana, confirma uma tendência nacional.

Para VIEIRA (1998 p.60), na prática a esterilização é realizada de forma clandestina, através de cesarianas, e o pagamento tem sido considerado como um fator importante na obtenção do procedimento. Ainda, segundo a autora, "a clandestinidade em que é realizada essa cirurgia não propicia que a candidata à esterilização seja orientada e devidamente informada. Por razões éticas e para evitar o arrependimento, a orientação e aconselhamento como posse total das informações pertinentes à esterilização, são fundamentais durante o processo de decisão sobre a esterilização".

FAUNDES e HARDY (1999), afirmam que, frequientemente, ligaduras são realizadas sem a necessária informação e que o desconhecimento sobre outros métodos e a falta de informação sobre a cirurgia, estão entre os fatores mais importantes que se associam ao arrependimento posterior.

Para GIFFIN e COSTA (1999), dada à ambigüidade legal da esterilização, a intervenção durante o parto permite esconder o procedimento que é cobrado "por fora". Existe, no país, um ciclo vicioso perfeito entre o aumento do parto cesariano e o aumento da esterilização. Todavia o efeito das cesáreas desnecessárias, sobre a saúde da mãe e filho é, um assunto sobre o qual não há dado epidemiológico.

Um registro que chama a atenção é que a esterilização é obtida, fundamentalmente, via setor público (71\%) sendo que 48,9 ocorrem em Hospitais Públicos e 22\% em hospitais conveniados ao SUS (BEMFAM 1997).

Um dos fatores que podem estar contribuindo, para o estabelecimento desse padrão, é a ausência de ações efetivas do Estado, em relação à Saúde 
reprodutiva e ao planejamento familiar, deixando a esterilização a cargo de iniciativas privadas de diversas naturezas como organizações filantrópicas, os profissionais de Saúde e as mulheres isoladamente ( PIROTTA 1998).

\subsection{História e Políticas Públicas do Planejamento Familiar}

O Planejamento familiar transcende a questão saúde. Os discursos sobre planejamento familiar já se expressam nos primórdios do Brasil colonial, e perduram até início da República.

No período colonial a intensa participação da Igreja na vida dos cidadãos notadamente das mulheres, incentivando a sua obediência e servidão dos homens incluindo a procriação de tantos filhos quanto Deus ou a natureza determinassem. De forma particular e decisiva a Igreja tem como grande aliada a medicina. Os médicos e padres tinham acesso à intimidade das mulheres mesmo que com objetivos distintos enquanto um voltado ao cuidado do corpo outro ao cuidado da alma. Desta forma estava-se garantindo o ideário social que se pretendia: português e cristão (COSTA AM 1999).

$\mathrm{Na}$ época do Brasil Colônia ao início da República, já se observa uma política pró-natalista. O desenvolvimentismo pós-guerra explicita mais claramente essa tendência, por parte do Estado Novo de Getúlio, e se efetiva a partir da criação do Salário Família e do Auxílio Natalidade.

Ao mesmo tempo, no cenário internacional, são revisitadas as teses de Thomas Robert Malthus (1766-1834), economista e demógrafo inglês que descreveu a teoria de contenção demográfica até hoje conhecida com o nome de neo maltusianismo. Segundo esta tese, é impossível alcançar o bem estar geral sem a contenção demográfica, pois o crescimento demográfico é sempre maior que a produção de bens: a produção de bens cresce em proporção aritmética; a população em proporção geométrica (PESSINI 2000).

Em 1952, Margaret Sanger criou, com sede em Londres, o International Planed Parenthood Federation (IPPF), que contava com o apoio de diversas instituições interessadas em planejamento familiar. O IPPF financiou, nos anos 
sessenta entidades e instituições que, no Brasil, realizaram planejamento familiar (COSTA A M. 1999).

Na década de 60, acirra-se a polêmica entre os políticos de controle demográfico e os anticontrolistas. $\mathrm{O}$ argumento favorável ao controle demográfico sustentava-se no principio de que o crescimento econômico, e o próprio desenvolvimento só seriam possíveis com a redução do ritmo demográfico. Os anticontrolistas, fundamentados nas denúncias do avanço imperialista, na nossa extensão territorial, na baixa densidade demográfica e na estratégia de sua ocupação, como forma de proteger a nossa economia e soberania nacional.

O debate persistiu durante as décadas de 60 e 70 . Mas na ausência de vida democrática, pouco se evoluiu no âmbito institucional na discussão da questão do ponto de vista do diretor da unidade ou das opiniões da sociedade. Entre pressões de natureza doutrinária e econômica, o governo brasileiro mantinha rigorosamente seu imobilismo (VALADÃO 1990).

A Igreja, naturalmente, sempre participava do debate com os argumentos de ordem moral e doutrinária, e relacionando o sexo à procriação. Essa posição passa a ser flexibilizada, na década de 70, quando passa a admitir o controle da fecundidade, através do treinamento para o uso de métodos naturais, o que representava um grande avanço.

No Brasil o movimento de mulheres por saúde, guardando vínculos com as manifestações feministas internacionais, foi de grande efervescência na década de 70, ampliando o debate sobre as questões de cidadania, sexo, saúde da mulher e mais adiante na década de 80 a saúde reprodutiva mereça grande atenção e investimento do movimento feminista. (ÁVILA e CORRÊA 1999) e (FORMIGA FILHO 1999) corroboram dizendo: em 1975 o movimento de mulheres, engessado durante os governos militares, reorganizou-se abrindo intensos debates sobre todas as formas de discriminação, a que estavam submetidos, com denúncias especiais da precariedade do quadro de saúde da mulher exigindo respostas governamentais.

No campo das políticas públicas surgiam estratégias, mesmo que não muito claras, para o controle da fecundidade, e que às vezes recuavam diante das reações sociais e da fragilidade política da época. 
A Conferência Mundial da População, realizada em 1974 no México, levantou debate sobre a questão demográfica. Aspectos, ali discutidos, foram levados em consideração pelo Conselho de Desenvolvimento Social, resultando em 1977, na criação do Programa de Saúde Materno Infantil (PSMI) e a ele foi incorporando o termo Paternidade responsável. Também em 1977 no mesmo contexto do PSMI foi elaborado o Programa de Prevenção da Gravidez de Alto Risco (PPGAR), que previa a oferta de contracepção à mulher em risco gestacional. A utilização de critérios pouco claros suscitou grandes polêmicas. A iniciativa perdeu de vista os seus reais objetivos, passando a ser vista e entendida como estratégia de controle de nascimento das populações pobres e negras (COSTA A M. 1999; FORMIGA FILHO 1999).

A falta de políticas claras, e a fragilidade, com que, à época, o Ministro da Saúde enfrentou a situação, deram lugar ao aparecimento de um vácuo institucional. Assim, o não delineamento desta política acabou por favorecer o surgimento, a implantação e o crescimento, no país, de instituições que ofereciam planejamento familiar. Dentre estas, a Sociedade Civil de Bem Estar Familiar no Brasil BEMFAM e o Centro de Pesquisa da Assistência Integrada à Mulher e a Criança (CPAIMC) foram as de maior relevância ( COSTA 1996).

A BEMFAM foi criada em novembro de 1965, como uma entidade privada sem fins lucrativos, com sede no Rio de Janeiro, financiada por capital internacional e filiada ao IPPF. As principais estratégias por ela empregadas foram o treinamento de profissionais de saúde para a prática de planejamento familiar, e a prestação de assistência exclusiva em ações contraceptivas. Estas ações realizaram-se por meio de Unidades próprias ou conveniadas com prefeituras, sindicatos, Secretarias de Saúde e Universidades (COSTA A M.1999).

A BENFAM estendeu sua rede privada de Serviços de planejamento familiar com intervenção, em quase todo território nacional, principalmente na região Nordeste.Suas atividades constituíam-se da oferta de serviços gratuitos de planejamento familiar, por meio da distribuição de pílulas e da instalação de Clínicas, estas totalmente financiadas pela instituição. Em 1973, começou a fazer adeptos no setor público, através da celebração de acordos e parcerias com estados e municípios (SILVA 1986). 
Pesquisas realizadas pelo Conselho Estadual de Condição Feminina, em São Paulo, revelaram que este serviço contava com a esterilização como alternativa importante na contracepção. (VALADÃO 1990).

Talvez, esta atuação tão efetiva, tenha colaborado para alterar o comportamento reprodutivo da população feminina em todo território nacional, e conseqüentemente, a queda da fecundidade à partir da década de setenta.

Na visão de CANESQUI (1984), a BEMFAM apresentou um modelo de assistência inspirada em uma visão ideológica que privilegiava os aspectos biológicos da reprodução. Este posicionamento difundia métodos anticoncepcionais, de alta tecnologia, e pretendia fazer com que o planejamento familiar assumisse um caráter de medida de Saúde Pública, ao usá-lo como arma na cruzada contra o aborto provocado.

No que diz respeito ao CPAIMC, o financiamento de suas atividades provinha de instituições vinculadas ao Sistema USAID (United Sates Agency for International Development) - pela Family Planning International Assitence FPIA, Pathfind Fundation e outras. Sua estratégia contribuiu para consolidação da cultura contraceptiva entre os Profissionais de Saúde especialmente os médicos. Para tanto, financiou treinamento de profissionais vinculados ao ensino da medicina, da enfermagem, e outras áreas afins, além de sustentar os profissionais - treinando-os, dando o equipamento e subsidiando as suas atividades. Uma verdadeira rede de médicos, que realizavam esterilizações cirúrgicas por meio da técnica da laparoscopia ( COSTA A M. 1999).

$\mathrm{Na}$ verdade, a oferta de meios anticoncepcionais havia-se difundido no país. As mulheres queriam meios de regularização da fecundidade, mas o estado não os oferecia. Nos programas não governamentais, a falta de informação adequada e a má qualidade dos serviços oferecidos fizeram com que mulheres vivessem experiências trágicas, ao usar os métodos oferecidos, terminando por desacreditar na anticoncepção reversível e se orientado gradativamente para a opção preferencial da esterilização (ÁVILA e CORREA 1999). 
A posição Brasileira na Conferência Internacional de Bucareste, em 1974, era ainda a de que não havia necessidade de estabelecer uma política para o setor, pois o país podia absorver o seu crescimento populacional.

A questão demográfica foi discutida na Conferência Mundial de População, realizada em 1974 no México, e resultou no anúncio, proferido pelo Conselho de Desenvolvimento Social em 1977, da criação do Programa de Saúde Materno Infantil que contempla a prevenção da gestação de alto risco. Sem a clareza necessária, vez que, os critérios apresentados eram pouco claros, grandes polêmicas foram suscitadas pela esquerda, por feministas e difusores do planejamento familiar, o que culminou por inviabilizar a sua aplicação (MINISTÉRIO DA SAÚDE 19851997).

Desde a década de 60, inspiradas pelo movimento feminista internacional e no clima de liberdade sexual conferida pela pílula contraceptiva, as mulheres brasileiras vinham processando uma ruptura com o clássico papel social que thes eram atribuídos: de mãe e de dona de casa. O movimento feminino brasileiro é de crucial importância ao direcionamento de políticas públicas da saúde da mulher.

Em 1975 o movimento de mulheres, engessado durante os governos militares, organizou-se abrindo intensos debates sobre todas as formas de discriminação a que estavam submetidas as brasileiras.Levantaram-se denúncias especiais da precariedade do quadro de saúde da mulher, exigindo respostas governamentais (MINISTÉRIO DA SAÚDE 1985-1997).

Os estudos realizados, pelas feministas, também revelaram vieses de classe e raça na relação entre profissionais médicos e usuárias. E no âmbito das análises, sobre a oferta e acesso ao procedimento de esterilização feminina, o momento tornou visível a lógica de mercado que orientava a prática de alguns setores médicos, assim como os seus vínculos com o clientelismo político (CPI da Esterilização Nacional e CPI da Assembléia Legislativa do estado de Pernambuco) (ÁVILA e CORREA 1999).

A partir dos meados da década de 80 , as feministas condensariam suas discussões ao redor de dois temas: as tecnologias contraceptivas e a crescente incidência da esterilização. Com base em pesquisas e reflexões, firmou-se, naquele 
momento, a premissa de que o acesso, à anticoncepção, era direito básico da cidadania das mulheres e deveria ser oferecida na rede pública de saúde como componente de uma política mais ampla de saúde reprodutiva, que incluiria assistência de qualidade no pré-natal, parto e puerpério; prevenção da DST e do câncer cervical e de mama; atenção ao adolescente e à mulher no climatério, ou seja, a implantação do PAISM (ÁVILA e CORREA 1999).

O Programa de Assistência Integral à Saúde da Mulher (PAISM) MINISTÉRIO DA SAÚDE (1984), concebido, em 1983 e regulamentado em 1986, resultou do empenho de profissionais de saúde do movimento das mulheres e dos técnicos do próprio Ministério da Saúde, no sentido de preconizar ações que ampliassem, significativamente, a atenção à saúde da mulher.

O PAISM tem, em sua fórmula teórica, o marco de sua força, representando um modelo de política pública de saúde, constituindo-se de um conjunto de diretrizes e princípios destinados a orientar todas as assistências oferecidas às mulheres de distintas faixas etárias ou classes sociais, nas suas necessidades epidemiologicamente detectáveis - incluindo a demanda específica do processo reprodutivo. Em 1987, o Ministério da Saúde, através do PAISM, incorporou definitivamente as atividades de planejamento familiar como uma prioridade no atendimento às pessoas (COSTA A M 1999; FORMIGA FILHO 1999; MARCOLINO 2000). As premissas básicas que fundamentam o PAISM, no que se refere ao planejamento familiar, são de que:

- A decisão sobre o número e espaçamento de filhos é direito inalienável do indivíduo.

- O governo brasileiro não impõe conotação demográfica que use o aumento, manutenção ou redução do número de nascimentos, mas tão somente deseja a diminuição da morbi-mortalidade materno-infantil.

- A ação do estado restringe-se a garantir a todos os brasileiros, informação e acesso necessários à prática de planejamento familiar entendido como tal, assistência à infertilidade conjugal ou decisão consciente na escolha de metodologia contraceptiva. 
- O planejamento familiar não deve ser implantado isoladamente, mas sim oferecido à população dentro do conjunto de ações que visam a assistência integral à saúde.

- O estado deve exercer rigorosa vigilância sanitária sobre o uso de metodologia contraceptiva (fertilização assistida) ou contraceptiva no sentido de anular possíveis repercussões ominosas aos usuários desta técnica, com procedimentos integrados ao Ministério, Secretarias Estaduais e Municipais de Saúde.

- O estado deve analisar e acompanhar, cuidadosamente, os protocolos de pesquisa em tecnologia na área de reprodução humana, evitando a possibilidade de comprometimento à saúde da população.

- Nenhum procedimento na área de planejamento familiar é totalmente inócuo, existindo sempre a necessidade de avaliação técnica adequada que garanta o acompanhamento dos usuários por pessoal capacitado, com qualidade e resolubilidade.

Apesar do PAISM ter sido formulado objetivando a saúde das mulheres, no campo da contracepção, BERQUÓ (1999), afirma que dramaticamente, com relação à esterilização, o PAISM não foi capaz de reverter as tendências de utilização no País.

A Constituição Federal de 1988 (BRASIL 1988), vem proteger o direito à saúde da mulher no seu artigo 226, parágrafo $7^{\circ}$ : "Fundado nos princípios da dignidade da pessoa humana e da paternidade responsável, o planejamento familiar e de livre decisão do casal, competindo ao estado propiciar recursos educacionais e científicos para o exercício desse direito, vedada qualquer forma coercitiva por parte das instituições oficiais ou privadas."

No plano dos conceitos e políticas para a saúde da mulher o PAISM satisfaz inteiramente. O grande dilema é a sua efetiva implantação, visto que ainda é preocupante o nível de saúde evidenciado pelos indicadores epidemiológicos, bem como a insatisfação das usuárias do Serviço de Saúde (Costa 1992 Apud COSTA AM 1999). 
A autora aponta a mortalidade materna e as altas taxas de esterilização cirúrgica feminina como indícios da falta de impacto na população feminina dos programas do PAISM. Sugere, ainda, que as mulheres não estão dispondo de outras alternativas contraceptivas para a necessidade ou desejo de regulação da fertilidade.

Apesar de haver a atitude oficial, sobre o planejamento e a reprodução humana, a acessibilidade aos métodos não é concreta. O sistema público de saúde não oferece muitas opções para a maioria da população. Por outro lado, o nível de informação impede o exercício pleno do direito ao planejamento familiar, pois as mulheres, na maioria das vezes, conhecendo, apenas, a ligadura tubária e a pílula não utilizando outros métodos.Ao lado disso há o problema de, muitas vezes, esse conhecimento ser adquirido através da conversa com outras mulheres que já fizeram uso do método. Esta realidade mostra a necessidade, cada vez mais urgente, de se proceder a uma avaliação detalhada da qualidade dos serviços de planejamento familiar que estão sendo oferecidos na rede pública de saúde.

Para BARBIERI (1996), as mulheres deveriam contar com serviços em que recebessem informação sobre todos os métodos contraceptivos existentes, seguindo a própria filosofia do planejamento familiar, através de práticas educativas, a fim de estarem habilitadas a escolher um método adequado e apropriada assistência no período reprodutivo.

Na visão de MÉDICI e BELTRÃO (1995), a esterilização parece ser o resultado da ausência de política governamental definida para o planejamento familiar como corolário deste processo, a demanda espontânea e não orientada acaba por levar à opção por soluções definitivas que, nem sempre, são as mais adequadas caso sejam considerados o futuro da família e o direito de as mesmas escolherem livremente a dimensão da prole.

Mesmo que reconheçamos o direito que a mulher tem ao método definitivo cirúrgico, fica o questionamento sobre as condições nas quais essa escolha se processa. 


\subsection{Aspectos Jurídicos da Esterilização}

Até recentemente a situação legal da esterilização era pouco definida. Considerou-se por muito tempo, a prática enquanto delito de lesão corporal. Todavia, a ilegalidade da ligadura tubária não se constituiu em impedimento para a sua realização de forma extensa.

Do ponto de vista jurídico a esterilização perpassa por três ramos do direito: o constitucional, o penal e o civil. Para compreender o tratamento jurídico destinado a esterilização é preciso observar estes três aspectos.

A Constituição Federal em seu artigo $226 \S 7^{\circ}$ (BRASIL 1998) declara que:

"Fundado nos princípios da dignidade da pessoa humana, e da paternidade responsável, o planejamento familiar é livre decisão do casal, competindo ao estado propiciar recursos educacionais e científicos para o exercício desse direito, vedada qualquer forma coercitiva por parte de instituições oficiais ou privadas".

A regulamentação dos direitos reprodutivos, a partir do referido artigo, constitui-se em um processo demorado e tumultuado. Depois de seis anos de tramitação no Congresso Nacional, o Projeto de Lei, que regulamentava esse parágrafo, foi finalmente aprovado com o texto da lei $\mathrm{n}^{\circ} 9263$ de 12 de janeiro de 1996.(BRASIL1998).

Esta Lei trata do planejamento familiar, estabelece penalidades e dá outras providências.

É BASTED (1999) que comenta: “Quando submetida à apreciação presidencial para ser sancionada, surpreendentemente teve vários artigos vetados. Essa lei, apesar de incorreções (fruto das negociações necessárias a sua tramitação no Congresso), incorporou propostas do movimento das mulheres. Este movimento, após o veto presidencial, teve que manter ativa sua mobilização para conseguir após mais de um ano, que o Congresso rejeitasse o veto e considerasse aprovado o texto integral da Lei.." 
Dentre os vetos da primeira versão da Lei, que só foi aprovada em 19 de agosto de 1997 , encontrava-se o Artigo $10^{\circ}$ que trata da esterilização. E está assim descrito.

Art. 10: "Somente é permitida a Esterilização voluntária nas seguintes situações:"

Parágrafo I - "em homens e mulheres com capacidade civil plena e maiores de vinte e cinco anos de idade, ou pelo menos, com dois filhos, vivos, desde que observando o prazo mínimo de sessenta dias entre a manifestação da vontade e o ato cirúrgico, período no qual será propiciado à pessoa interessada acesso a serviços de regulação da fecundidade, incluindo aconselhamento por equipe multidisciplinar, visando a desencorajar a esterilização precoce."

Parágrafo II - "risco à vida ou a saúde da mulher ou do futuro concepto, testemunhado em relatório escrito e assinado por dois médicos.(BRASIL1998)

A esterilização, quando efetuada sem o consentimento da mulher, enquadra-se no campo do direito penal caracterizando-se como lesão corporal, de natureza gravíssima, contida nos termos do artigo $129 \S 2^{\circ}$, inciso III do Código Penal Brasileiro. Por outro lado, quando a indicação é terapêutica, fica clara a exclusão da ilicitude do ato, como se observa no artigo 23 do referido código.(BRASIL 1998).

A Lei veta a esterilização cirúrgica em mulher durante o parto ou aborto, exceto em caso de comprovada necessidade de ordem clínica. Não reconhece validade à manifestação de vontade expressa durante ocorrência de alteração na capacidade de discernimento por influência do álcool, drogas, estados emocionais alterados, ou incapacidade mental temporária ou permanente.

Veta, ainda, a esterilização através da histerectomia e ooforectomia, e somente deverá ser executada através de laqueadura tubária, vasectomia, ou outro método cientificamente aceito. E que na vigência da sociedade conjugal a 
esterilização de um dos cônjuges depende do consentimento expresso de ambos os cônjuges.

Prevê, também, a necessidade de autorização judicial para a realização de esterilização cirúrgica em pessoas absolutamente incapazes.

Segundo a Lei, a autorização, para realização de esterilização cirúrgica somente será dada às instituições que ofereçam todas as opções de métodos contraceptivos reversíveis. Lembra a pena prevista no art. 129, § $2^{\circ}$ do Código Penal para esterilização cirúrgica realizada em desacordo com o previsto por ela. Além disso, aumenta a pena nos casos em que a esterilização é realizada durante o parto, ou aborto, e, ainda, através de cesárea indicada, unicamente, para a realização da esterilização (BRASIL 1998).

Até 1997 a esterilização não era recomendada pelo Ministério da Saúde, e só podia ser feita em casos em que houvesse risco de vida para a mãe, exigindo uma autorização consubstanciada que demonstrasse a necessidade de sua realização.

Em 1997 o Ministério da Saúde, através da Portaria n 144 de 20 de novembro de 1997, que regula a Lei ${ }^{\circ} 9263$, inclui a laqueadura tubária e a vasectomia no grupo de procedimentos cirúrgicos do Sistema Único de Saúde (SUS), nos termos que esta Lei prevê (MINISTÉRIO DA SAÚDE 1997).

Visando a desencorajar a esterilização precoce, a portaria institui critérios para o credenciamento de hospitais que farão os procedimentos de laqueadura de trompas e vasectomia. Estes hospitais deverão oferecer todas as opções de meios e métodos contraceptivos reversíveis, bem como devem comprovar a existência de médico capacitado para realização destas cirurgias.

A Portaria estabelece, ainda, que deverão constar, no prontuário da paciente as informações dos riscos da cirurgia, possíveis efeitos colaterais, dificuldade de reversão e as opções de contracepção reversíveis existentes. Preconiza, também, que a laqueadura tubária e a vasectomia são de notificação compulsória e fazem parte do Banco de Dados do Sistema Nacional de Agravos Notificáveis (SINAN). 
Ainda, no que diz respeito às penalidades da lei, está expresso no art. 21 do capítulo II da seguinte forma:

"Os agentes do ilícito e, se for o caso, as instituições a quem pertencem ficam obrigada a reparar os danos morais e materiais decorrentes da esterilização não autorizada na forma desta Lei, observados nesse caso, dispostos nos artigos 159, 1.518 e 1.521, e seu parágrafo único do código civil, combinados com o artigo 63 do Código de processo penal." (BRASIL1998).

Embora a Lei trate a esterilização com uma das penalidades previstas no Código Penal e Civil, há autores que têm um outro olhar sobre a questão. PIROTTA (1998) cita Parreira (1985), que sugere que a “esterilização voluntária deva ser colocada juridicamente no capítulo sobre Direitos Privados da Personalidade". Sujeita apenas à decisão do titular de tais direitos. Ou seja: aquele que deseja esterilizar-se tem o direito de fazê-lo sem infringir nenhuma norma de direito.

Ainda, PIROTTA (1998), ao refletir sobre a questão, acredita que a mais moderna doutrina do direito é unânime em localizar a esterilização no rol do direito reprodutivo, à medida que se mostra como meio de regulação da própria fecundidade.

Apesar da Lei se apresentar protecionista e paternalista, determinando alguns aspectos em relação à idade das mulheres, e ao número de filhos, é muito mais severa com o profissional e com as instituições que praticam a esterilização fora das normas preconizadas.

Aceitamos e aprovamos o direito da mulher em regular sua fecundidade, entretanto, acreditamos que há muitos "Brasis", como podemos observar na notícia veiculada em um jornal de grande circulação na Bahia, no dia 21 de abril de 2002. "Exatamente no dia do Índio - 19 de abril - a plenária da $4^{a}$ Câmara do Conselho Regional de Medicina do Estado da Bahia (Cremeb) suspendeu o registro do médico Roland Lavigne, deputado federal do PMDB, por 30 dias. As acusações que pesam sobre o médico-parlamentar são as de praticar ilegalmente a ligadura de trompas em índias, tornando-as inférteis sem o total conhecimento delas."( ANONYMUS 2002). 


\subsection{A Mulher e a Cultura da Esterilização}

A cultura da esterilização passou a fazer parte do processo reprodutivo das mulheres. Hoje podemos dizer que o ciclo reprodutivo da mulher é menstruar, engravidar, parir e esterilizar-se. Está incorporada às necessidades de parcela significativa de mulheres.

Segundo BERQUÓ (1993), no caso brasileiro pode-se constatar que está em curso a consolidação de uma verdadeira "cultura da esterilização", pela qual este procedimento passou a ser transmitido, de mãe para filha.E ainda BERQUÓ (1999), que faz referência a uma pesquisa, por ela realizada em 1996, quando constatou que, $52 \%$ das mulheres esterilizadas, eram filhas ou irmãs de esterilizadas, o que segundo a autora reflete uma propagação familiar inter e intrageracional.

Numa pesquisa realizada em uma comunidade quilombola de Pernambuco ANDRADE (1997), valida essa tendência ao relatar: entre as mulheres esterilizadas as duas duplas eram mãe e filha: uma mãe tinha 44 anos e sua filha 23 ; a primeira fora operada aos 37 anos, em 1989, a segunda em 1994, aos 19 anos. Comparando outra dupla, a mãe de 41 anos, e a filha de 25 anos; a primeira esterilizada em 1984 com 29 anos e a segunda em 1994, com 25 anos.

Observando os dados do PNDS de 1996 para o Nordeste, comparando-os aos de 1986 , o incremento da esterilização foi de $25 \%$ para $44 \%$. É importante ressaltar que $21 \%$ das mulheres recorreram à esterilização com menos de 25 anos.

Quanto à idade da esterilização, em todo o País, mais de um terço das mulheres esterilizadas apresentavam entre 25 e 29 anos à época da operação, e mais de um quarto tinha entre 30 e 34 anos de idade.

A mesma pesquisa refere-se ao nível da instrução como tendo bastante influência no uso de métodos. A esterilização feminina apresenta percentuais mais altos entre os de nenhum ou baixo nível de instrução o que vai diminuindo com o aumento do número de anos de estudo.(BEMFAM/DHS /MACRO 1997).

A precocidade da idade da esterilização é um motivo de preocupação com o uso do método, MINELLA (1998), afirma que mulheres que se esterilizam 
mais jovens, reclamam mais de problemas de saúde atribuindo-os à esterilização, cujo desdobramento repercute tanto na vida social quanto na afetiva. $O$ arrependimento possui um forte apelo emocional, acarretando consequiências no âmbito físico e psicológico da vida dessas mulheres.

Pesquisa, realizada no Recôncavo baiano mostrou que a laqueadura de trompas era o método anticonceptivo mais utilizado por $62 \%$ das mulheres até 39 anos. No caso das mulheres de mais de 40 anos esse percentual chegava a $89,5 \%$ (DALTRO et al 1992).

PINOTTI et al (1986), em estudo realizado com clientes de um hospital de Campinas São Paulo, em 1985, apontou a idade de esterilizar-se como um dos principais fatores associados ao arrependimento. Entre as mulheres que haviam se esterilizado, antes dos 25 anos, 50,0\% arrependeram-se de ter se submetido à cirurgia. OSSIS (1990), chega à conclusão de que o principal problema da laqueadura, realizada prematuramente, é a possibilidade de arrependimento, o que acontece quando, anos depois da cirurgia, a mulher passa por mudanças familiares, sociais e, até, econômicas em sua vida.

ANDRADE (1997), refletindo sobre a questão da ideologia da esterilização afirma que ao longo dos últimos trinta anos, a cirurgia para esterilização foi colocada no varejo e a oferta sofre algumas variações: ora depende do nível de instrução da mulher e de sua situação sócio-econômica, ora de conjunturas com o período eleitoral. Ocorre, ainda a sedução do bônus: a mulher encerra a carreira reprodutiva, e será feliz para sempre - considerações estas subentendida da apologia em torno dos estímulos existente para esterilizar-se.

Para MINELLA (1998), a laqueadura passou a ser tida como parte natural da experiência reprodutiva, sendo vista no mesmo patamar de outros eventos do ciclo biológico feminino, constituindo seu ponto de chegada.

OSSIS (2001), acredita que esse fenômeno requer um aprofundamento das motivações das mulheres para se esterilizarem. Segundo a autora, ao analisar trabalhos anteriores, a resposta mais frequente é: "Não queria ter mais filhos" e outras variações como: "Não podia mais ter filhos", "Não tinha como criar mais filhos," "Já tinha o número ideal/suficiente de filhos". E, que, embora reconheça esse 
direito, legítimo da mulher, em controlar o número de filhos, tal direito não precisa ser exercido apenas através da esterilização cirúrgica.

\subsection{Esterilização por Ligadura Tubária}

O método mais comum de esterilização feminina é a ligadura tubária. Consiste na oclusão ou seccionamento das Trompas de Falópio, de modo que o óvulo não fíca acessível à fecundação. Existem várias técnicas para laqueadura tubária. Segundo HATCHER et al (1983), foram desenvolvidas mais de cem técnicas de laqueadura tubária abdominal.

A laqueadura é usualmente realizada ocluindo as trompas com ligadura, com clips, anéis ou eletrocoagulação. Alguns métodos são mais danosos que outros. MOLINA (1999).

As vias de acesso mais utilizadas são a minilaparotomia e a laparoscopia. Os métodos de oclusão tubária mais empregados são os de Pomeroy, Madlener, Uchida e Irving, cuja técnica mais usada é a de Pomeroy. No que tange às complicações, as mais comuns da minilaparotomia são: infecção de incisão, hematoma, dano à bexiga e falha da cirurgia. A maior vantagem dessa técnica é ser pouco destrutiva, dando oportunidade a uma possível reversão (HATCHER et al. 1883; BRUNETT 1990; DIAS et al.1998).

A popularidade da ligadura tubária aumentou consideravelmente com o advento da técnica da laparoscopia, tornando-se um método mais largamente utilizado em todo mundo. É uma técnica que apresenta menor desconforto e rapidez cirúrgica, podendo, em alguns casos, ser utilizada anestesia local. As complicações mais comuns, ao uso desta técnica, dependem muito da experiência do cirurgião. Dentre elas encontramos lesões intestinais e hemorragias que podem ocorrer imediatamente, e mais tardiamente poderão acontecer varizes pélvicas, que podem causar dismenorreia, dispareunia e metrorragia ( HATCHER et al 1983).

Para BRUNETT (1990), as técnicas mais utilizadas para esterilização laparoscópicas são: 
- Eletrocoagulação unipolar: esta técnica produz coagulação da trompa e mesosalping adjacente.

- Eletrocagulação bipolar: técnica mais recente. Ela reduz significativamente o risco de todos os tipos de lesão térmica.

- Oclusão por anel tubário: primeiramente descrita por Yoon et al em 1974, utiliza uma tira de borracha de silicone para oclusão imediatamente pra fora do corno uterino.Apresenta a vantagem de eliminar a lesão térmica inadivertida.O desconforto pélvico pós-operatório é mínimo.

- Clipe tubário: o clipe tubário de mola é uma das modalidades mais recente. Esta técnica acarreta a destruição mínima ás trompas.

A ligadura tubária como método de esterilização feminina foi proposta em 1823, por James Blundell em Londres, objetivando evitar as cesarianas para esse fim, técnica muito perigosa na época. O registro da primeira ligadura, no entanto, data de 1881 e foi realizada por Samuel Lungren um médico de Ohio (BORDHAL 1985).

Embora a esterilização seja relacionada como método contraceptivo, este não é um entendimento unânime. De acordo com JONES e JONES (1990), anticoncepção é a abstinência temporária da fecundidade, enquanto que a esterilização, a despeito das mais modernas tecnologias, é considerada um método irreversível e definitivo.

A esterilização por laqueadura tubária é um procedimento que pode levar a complicações imediatas e seqüelas tardias. PERDIGÃO (1996), diz que entre as complicações mais comuns estão as hemorragias, roturas de intestino ou bexiga e infecções pélvicas. Cada um desses incidentes podendo levar a cirurgias posteriores mais ou menos extensas e mutiladoras. Entre as seqüelas tardias destacam-se as alterações menstruais com dor, alterações de sangramento e tensão pré- menstrual.

Estes distúrbios foram nomeados como "Síndrome pós-laqueadura", expressão que tem sido utilizada para um conjunto de sintomas que surgem após a esterilização cirúrgica e incluem: desordens menstruais, dor pélvica, mudança do 
comportamento sexual, manifestações endócrinas anormais, a exemplo de alterações nos níveis hormonais devido à menor irrigação sangüínea nos ovários.

O problema vem sendo estudado há mais de cinqüenta anos.A ocorrência de sintomatologia anormal após a esterilização tubária foi descrita pela primeira vez em 1951 por Willim et al (GENTLLE e cols 1998).

Para DIAS et al (1998), a síndrome pós laqueadura seria caracterizada por desarmonia menstrual ( metrorragia, sangramento inter-menstrual, spotting e amenorréia) algia pélvica, dismenorreia, dispareunia, tensão pré menstrual e manifestações psicológicas.

ESPIN (1981), define a síndrome pós laqueadura (ou síndrome de resíduos tubários), como sendo manifestações dolorosas endopélvicas, transtornos menstruais hemorrágicos e perturbações psíquicas, isto é, alterações que podem surgir depois da esterilização tubária por métodos habituais (Madlena, Pomeroy, Irving, Kroener, Uchida etc).

Para alguns autores as alterações podem estar ligadas às técnicas utilizadas na realização da laqueadura. No estudo de DIAS et al (1998), as técnicas mais utilisadas, em nosso meio foram as de minilaparotomia (Pomeroy), e o uso de "anel de yoon" (anel de silastic) perfazendo um total de 74,7\% dos casos.

É PERDIGÃo (1996) que aponta a "causa vascular" como uma das hipóteses que tenta explicar os mecanismos envolvidos nessas alterações. Segundo a qual no momento da laqueadura pode ocorrer comprometimento dos ramos ovarianos, por insuficiente irrigação dos ovários, e, conseqüentemente, perturbação da estriodogênese gonodal.

Embora existam controvérsias quanto aos efeitos colaterais, desta natureza, em mulheres que se submeteram a laqueadura, em estudo realizado sobre a síndrome pós-laqueadura, notadamente no que diz respeito a alterações menstruais, MINELLA (1998), e OSSIS (2001), encontraram associações significativas da queixa dos distúrbios menstruais das mulheres, segundo a percepção das mesmas após a ligadura tubária. 
Outro problema que hoje afeta, cada vez mais, mulheres em nosso País que optaram por esta forma de contracepção é o arrependimento que surge, em algum momento, após a esterilização, como já foi abordado anteriormente.

\subsection{As Opções de Métodos Contraceptivos}

A opção por um método contraceptivo sempre traz conflito. Os métodos reversíveis oferecidos às mulheres, que apresentam melhor eficácia, não são isentos de efeitos colaterais. Por outro lado, aqueles menos inócuos, como os chamados de barreira e comportamentais, são os que apresentam maiores riscos de engravidar.

Para CARVALHO (2001), as mulheres, que vão em busca da contracepção, têm dois tipos de demanda: as que desejam esparçar ou evitar o nascimento de filhos; e aquelas que já atingiram o número desejado de filhos. Para o grupo que já atingiu o número desejado de filhos, a esterilização tem sido mais utilizada do que os métodos reversíveis.

O MINISTÉRIO DA SAÚDE (1996), preconiza que se deve indicar e/ou fornecer todos os métodos anticoncepcionais disponíveis no Brasil, uma vez amparadas por normas éticas e legais. No âmbito da Assistência Integral à Saúde, a assistência ao planejamento familiar deve ser organizada para atender às reais necessidades da população feminina e masculina, em idade fértil, através da utilização dos conhecimentos técnicos e científicos existentes e dos meios e recursos mais adequados e disponíveis para tal. Faz, ainda, referência à indicação de anticoncepção em fases específicas, como no pós- parto e pós- abortamento, na adolescência, na pré menopausa, e na anticoncepção de emergência.

Os métodos preconizados pelo MINISTÉRIO DA SAÚDE (1996), são distribuídos em várias classes: os chamados Métodos Naturais ou Comportamentais, os Métodos de Barreira, os Despositivos Intra Uterinos (DIU), os Anticonepcionais Hormonais (orais, injetáveis, e implantes) e a Anticoncepção Cirúrgica Voluntária.

A seguir, faremos um breve relato sobre as classificações, definições, tipo de método em cada categoria, e mecanismo de ação. 
$>$ Métodos Naturais ou Comportamentais

- Método de Ogino-Knaus ou calendário ou tabelinha

- Método da temperatura Basal corporal

- Método da Ovulação ou Billings

- Método Sintotérmico

- Coito Interrompido

Os métodos naturais, ou comportamentais, são meios utilizados para possibilitar ou evitar a gravidez, mediante a observação das modificações fisiológicas que ocorrem no organismo feminino durante o ciclo menstrual. Estes métodos exigem do casal abster-se das relações sexuais durante o período fértil da mulher.

Embora sejam métodos que não ofereçam risco à saúde, não têm ampla aceitação pelos casais devido, entre outros aspectos a baixa eficácia quando as técnicas de cada um deles não são rigorosamente observadas.

$>$ Métodos de Barreira

- Preservativos

- Diafragma

- Espermaticida

São métodos que colocam obstáculos físicos ou químicos à penetração dos espermatozóides no canal cervical, com a finalidade de impedir a gravidez.

Uma de suas vantagens é que não apresentam efeitos colaterais sistêmicos. Mas, enquanto os preservativos necessitam da colaboração masculina, o diafragma necessita de manuseio, o que dificulta o uso, como também necessita de motivação para o uso a cada relação sexual. Quanto aos espermicidas há queixas de irritação tanto vaginal quanto peniana, e, também, a sensação de calor na vagina. Outro agravante se constitui na baixa eficácia que oferece, visto que devem ser usados de 10 a 15 minutos antes das relações sexuais, e só tem ação efetiva durante 1 a 2 horas. 


\section{Dispositivo Intra Uterino (DIU)}

Os primeiros DIUs modernos (alça de Lippis e espiral Margules) surgiram no princípio dos anos sessenta, sendo que no final da década se agregou-se cobre ao plástico, o que aumentou sua eficácia e diminuiu os efeitos colaterais surgindo, então, os DIUs TCu 200, Cu 7 e Multiload Cu 250.

Estes dispositivos causavam menos efeitos colaterais, eram mais eficazes, e deram origem a uma outra geração de DIUs de cobre, mais eficazes e de maior duração.

O Tcu $350^{\mathrm{A}}$ já foi liberado para uso durante 10 anos. Seu índice de falha é de menos de 01 por 100 mulheres/ano (SECRETARIA DE SAÚDE DA BAHIA1998).

Outro DIU existente no mercado internacional é o liberador de progesterona. É de alto custo e tem durabilidade de apenas um ano. Sua eficácia é alta, e é o único que reduz a perda sangüínea durante o período menstrual. Para substitui-lo surgiu o DIU de Levonorgestrel (LNG 20) com duração prevista de cinco anos e, também, de elevada eficácia.

O mecanismo de ação do DIU é tornar o muco cervical hostil à penetração dos espermatozóides, interferir na capacidade de os espermatozóides atravessarem a cavidade uterina. Intervir no processo reprodutivo, antes da fecundação, e causar alteração no endometrio.

Embora seja um método, altamente eficaz, que não interfere nas relações sexuais, e possibilita retorno imediato da fertilidade, apresenta efeitos colaterais tais como: aumento do fluxo menstrual, cólicas, e pode ser expulso espontaneamente. Uma mulher com tendência à anemia poderá ter agravado esse quadro, assim como levar a complicações mais graves como as doenças pélvicas inflamatórias. Alie-se a isso, o fato do DIU não proteger a mulher de uma gravidez ectópica.

$>$ Anticoncepcional Hormonal:

- Pílulas combinadas

- Minipílulas 
Os anticoncepcionais orais combinados, também chamados pílulas anticoncepcionais, são esteróides, estrógenos, associados ao progestágeno, utilizados com a finalidade de impedir a concepção.

As pílulas combinadas atuam basicamente inibindo a ovulação, além de provocar alterações nas características do muco cervical do endométrio e na motilidade das trompas dificultando, assim, o acesso do espermatozóide.

Quanto aos tipos de pílulas, existem as monofásicas, com 21 pílulas ativas que contém a mesma quantidade de estrógeno e progestágeno, e as trifásicas com três combinados diferentes de estrógeno e progestágeno E/P (6/5/10) com 21 pílulas ativas. Existem algumas cartelas, com 28 pílulas, sendo que as últimas sete não contêm hormônios e sim placebo.

Os anticoncepcionais orais são altamente eficazes, convenientes e fáceis de usar: reduzem fluxos menstruais, e cólicas. Os efeitos colaterais mais comuns que apresentam, são: amenorréias, náuseas, tonturas e vômitos, cefaléias e sensibilidade nas mamas. Contra-indicadas no caso das fumantes, cardíacas, hipertensas e mulheres com varizes. É o método de maior aceitação pelas mulheres, e, atualmente, concorre em aceitação diretamente com a esterilização.

Anticoncepcional Hormonal Injetável

Os anticoncepcionais injetáveis combinados são compostos de estrógeno associado a um progestágeno. Têm como finalidade básica impedir a gravidez.

O mecanismo de ação é o mesmo que se emprega aos anticoncepcionais orais. Os efeitos colaterais relatados são: cefaléia, tensão, trombose, flebites, mudança no padrão de sangramento menstrual e aumento de peso.

Apesar de apresentar a mesma eficácia e os mesmos efeitos colaterais que o anticoncepcional hormonal oral, é de aceitação bem menor do que este.

Os anticoncepcionais orais e injetáveis podem, ainda, se apresentar contendo, exclusivamente, progestágeno, embora apresente o mesmo mecanismo de ação e as mesmas indicações gerais. Tem, apenas a vantagem de não interferir na amamentação, podendo ser usado seis semanas após o parto. 
Quanto aos efeitos colaterais e as contra-indicações, estes são idênticos aos produzidos pelas pílulas e aos injetáveis combinados. Outro aspecto importante, no que tange aos anticoncepcionais hormonais injetáveis, é que os combinados são usados, a cada 30 dias, enquanto que as só de progestágeno são usadas a cada três meses (Depo-provera), ou a cada dois meses como é o caso do Noristrat.

Implantes exclusivamente de Progestágeno

São anticoncepcionais hormonais exclusivamente de progestágeno. Apresentados sob a forma de seis cápsulas finas flexíveis contendo Levonorgestrel, que são inseridas no tecido subcutâneo da parte superior interna no braço da mulher. O tipo existente é o Norplant. O mecanismo de ação é idêntico aos demais anticoncepcionais hormonais, assim como sua eficácia. Não afetam a amamentação e o efeito contraceptivo é de 05 anos. Além dos efeitos colaterais, serem semelhantes aos dos demais anticoncepcionais hormonais pode haver infecção no local da inserção da cápsula assim como esta sair do local implantado.

Anticoncepção cirúrgica voluntária

- Ligadura Tubária

- Vasectomia

São procedimentos cirúrgicos de caráter voluntário com vistas ao término da fertilidade.

O mecanismo de ação, no caso da ligadura tubária se dá através do bloqueio tubário que impede o encontro do óvulo com o espermatozóide. Constituise, portanto, de um método permanente, operacionalizado através da obstrução do lúmen tubário impedindo, desta forma, o transporte e a união dos gametas .

A vasectomia consiste na secção e/ou oclusão dos canais deferentes. Bloqueia-se o ducto deferente (ducto ejaculatório) o que resulta na ausência de espermatozóide na ejaculação. Trata-se de um método seguro, eficaz e de fácil execução.

Tanto a ligadura tubária como a vasectomia, são métodos permanentes e de difícil reversibilidade. 
O fato do Programa de Atenção à Saúde da Mulher preconizar a disponibilização de todos os métodos acima referidos, ás vezes, o acesso a todos os métodos não é uma realidade; como também às vezes ocorre a descontinuidade no fornecimento dos mesmos nas Unidades Básicas de Saúde. O que podemos registrar no nosso dia - a - dia nas Unidades Básicas de Saúde ou, mesmo, durante a execução das investigações para este estudo.

Ao analisarmos os dados do PNDS (BEMFAM/DHS/MACRO1997), referentes ao conhecimento e uso dos métodos contraceptivos no Brasil (Quadro 1) fica destacada a grande preferência das mulheres por apenas dois métodos: a pílula e a esterilização. Embora, quando se reportam ao conhecimento de algum método, há maior homogeneidade nas respostas, no sentido de conhecer os métodos existentes.

Quadro 1 - Porcentagem de todas as mulheres em idade reprodutiva, e mulheres unidas, que conhecem métodos contraceptivos e que estão usando, atualmente, algum método, segundo o tipo de método. Brasil, 1996.

\begin{tabular}{lcccc}
\hline \multicolumn{1}{c}{ Modas as Mulheres } & \multicolumn{2}{c}{ Mulheres Unidas } \\
\hline Algum método & Conhecem & Usam atualmente & Conhecem & Usam atualmente \\
\hline Esterilização feminina & 99,6 & 55,4 & 99,9 & 76,2 \\
\hline Pílula & 94,1 & 27,3 & 96,8 & 40,1 \\
\hline Condom & 98,8 & 15,8 & 99,4 & 20,7 \\
\hline Esterilização Masculina & 76,2 & 4,3 & 98,9 & 4,4 \\
\hline Injetáveis & 84,3 & 1,6 & 79,5 & 2,6 \\
\hline DIU & 73,6 & 0,8 & 88,5 & 1,2 \\
\hline Métodos Vaginais $(*)$ & 44,5 & 0,1 & 76,5 & 1,1 \\
\hline Abstinência Periódica(**) & 85,2 & 2,0 & 87,5 & 0,1 \\
\hline Coito interrompido & 64,1 & 2,1 & 68,0 & 3,0 \\
\hline Outros (***) & 2,6 & 0,2 & 3,0 & 0,3 \\
\hline (*) inclui dafagma, espuma & & 1,1 & 3,1 \\
\hline
\end{tabular}

$\left({ }^{*}\right)$ inclui diafragma, espuma tabletes. $\left({ }^{* *}\right)$ inclui tabela, billings, temperatura nasal $\left({ }^{* * *}\right)$ inclui ervas, chás, etc.

Fonte: Pesquisa Nacional sobre Demografia e Saúde/BEMFAM /DHS/ MACRO1997. 
Para BERQUÓ (1993), esta concentração nos dois métodos: pílula anticoncepcional e esterilização,deve-se à falta de alternativa anticoncepcionais para a maioria das mulheres brasileiras que buscam a pílula, geralmente comprada em farmácia, e sem acompanhamento médico, e ser o método reversível mais eficaz. $\mathrm{E}$ sem o recurso do aborto legal (em caso de falha da pílula), a esterilização aparece como a tábua de salvação, contra o desamparo em que as mulheres vivenciam a saúde reprodutiva.

DIAZ e DIAZ (1999), analisando a livre escolha dos métodos, afirmam existir muitas restrições á livre escolha, derivados da falta de opções anticoncepcionais, e pela atitude dos provedores. O acesso a alguns métodos é quase inexistente, como no caso do diafragma, estendendo-se a outros métodos como o DIU e os injetáveis. É importante salientar que a falta de acesso a alguns métodos pode dever-se à falhas estruturais de alguns serviços, como falta de pessoal treinado ou de suprimentos, ou falha no sistema de distribuição, quer porque estes não são comprados ou quer pela falta real deles.

E continuam: Embora tenha sido feito importante esforço para difundir o conceito de que o planejamento familiar é um direito que envolve livre escolha de métodos, poucos são os provedores que realmente possibilitam tal escolha. 


\section{OBJETIVOS}

- Conhecer os motivos que levam mulheres residentes em Feira de Santana a buscar a esterilização como método contraceptivo

- Avaliar a informação de mulheres esterilizadas, a respeito das implicações da esterilização. 


\section{PROCEDIMENTOS METODOLÓGICOS}

\subsection{Estratégia da Pesquisa}

Ao se ter a definição do problema que se desejava investigar, começou-se a pensar o caminho metodológico mais adequado para obter as respostas desejadas. Optou-se então pela pesquisa qualitativa como uma abordagem adequada para a condução desse estudo.

Para TRIVIÑOS (1992), a pesquisa qualitativa permite compreender a situação crítica onde a mesma ocorre, sem criar situações simuladas que distorcem a realidade ou levam a interpretação ou generalidades equivocadas. Conforme a visão de MINAYO (1994), "a investigação qualitativa requer como atitudes fundamentais a abertura, a flexibilidade, a capacidade de observação e de interação com o grupo de investigadores e com os atores sociais envolvidos. Seus instrumentos costumam ser facilmente corrigidos e readaptados durante o processo de trabalho de campo, visando às finalidades da investigação"(p.101).

Nosso estudo procurou identificar os motivos que levam mulheres a escolher a esterilização como método contraceptivo, as informações que têm a respeito desse procedimento, e sua trajetória no uso dos métodos contraceptivos até a esterilização.

A abordagem qualitativa permite melhor compreender estas questões quando, segundo MINAYO (1994), trabalha-se com o universo de significados, motivos, aspirações, crenças, valores e atitudes, correspondendo a um espaço das relações onde a ênfase maior está no processo de como ocorrem essas relações, e, não somente, no resultado do produto.

É desta forma, portanto, que serão focalizadas as experiências e vivências das mulheres que decidiram pela esterilização cirúrgica feminina.

A análise da fala dos atores sociais representados pelas mulheres esterilizadas, será resgatada através do método da análise de conteúdo, que de acordo com o que diz BARDIN (1977), é um método que se presta para o estudo das motivações, atitudes, valores crenças e tendências. 


\subsection{As Representações Sociais}

Elegemos a Teoria das Representações Sociais, como base teórica deste trabalho, tendo em vista que os sujeitos trazem à tona, através de suas falas, as representações que possuem acerca de determinado problema investigado.As representações sociais são manifestadas em palavras e condutas, que se sedimentam nas instituições, grupos sociais e indivíduos.

A Teoria das Representações Sociais foi introduzida pelo psicólogo francês, Serge Moscovici através do seu estudo A psicanálise, sua imagem e seu público, tomando como objeto de pesquisa a apropriação da psicanálise, pelo grande público francês dos anos 50. Este estudo difunde esse saber cientifico inédito, transformando-o numa forma de conhecimento socialmente elaborado e partilhado, enquanto saber prático do senso comum (NOBREGA 1990).

Vários foram os estudiosos e pesquisadores que aprofundaram os estudos das representações sociais, para as quais apresentam facetas conceituais diversas.

O conceito original foi proposto pelo sociólogo francês Emile Durkheim, elaborado como conceito de "representação coletiva", ou seja: uma espécie de guarda-chuva que reúne larga gama de diferentes formas de pensamento e saberes partilhados coletivamente (crenças, mitos, ciências, religiões, opiniões), cuja característica consiste em revelar o que há de irredutível à experiência individual e que se estende no tempo é no espaço social. (NOBREGA 1990, p.03).

MOSCOVICI (1981), afirma que é inquestionável que devemos a Durkheim, o conceito de "representações sociais". Todavia, ele o aborda de um ângulo diferente, porque: enquanto do ponto de vista de Durkhim, as "representações coletivas," articulam uma vasta classe de formas intelectuais; ele adicionou a esse conceito, duas modificações importantes: que as "representações sociais" precisam, por um lado, ser compreendida como uma forma particular de adquirir conhecimento, e por outro, comunicar o conhecimento que já tem sido adquirido.

Na visão de GUARESCHI (1995), Moscovici preferiu preservar o conceito de representação e substituir o conceito "coletivo" segundo ele, carregado 
de conotação mais estática e positivista, por social: daí o conceito de Representações Sociais.( p.196).

\section{Para Moscovici:}

A representação social "é uma instância intermediária entre conceito e percepção; que ela se situa sobre as dimensões de atitudes, informações e de imagens; que ela contribui para formação das condutas e a orientação das comunicações sociais; que ela conduz a processos de objetivação, de classificação e ancoragem; que ela se caracteriza por uma focalização sobre uma relação social e uma pressão à inferência; e, sobretudo, que ela se elabora nas diferentes modalidades de comunicação: a difusão, a propagação e a propaganda" (DOISE apud NOBREGA 1990, p. 11).

Para Jordelet:

"É um conhecimento socialmente elaborado e partilhado, com que se pode pretender dominar essencialmente o nosso entorno, compreender e explicar os fatos e idéias que povoam nosso universo de vida ou que surgem nele, atuar com e sobre outras pessoas, situar-nos em relação a elas, responder a questões que nos coloca o mundo, saber o que significam os descobrimentos da ciência e o dever histórico para a condução de nossas vidas, ou seja, trata-se de um conhecimento prático" (JORDELET 1986, p. 473).

MINAYO (1994) entende este conceito como "um termo filosófico que significa a reprodução de uma percepção anterior ou do conteúdo do pensamento. Nas ciências sociais, são definidas como categorias de pensamento, de ação e de sentimento que expressam a realidade, explicam-na justificando-a ou questionandoa"(p. 158).

Abric apud OLIVEIRA ( 2000), entende as representações sociais como um conjunto organizado de informações, atitudes e crenças em que um indivíduo ou um grupo, elabora a propósito de um objeto, de uma situação, de um conceito, de outros indivíduos ou grupos, apresentando-se portanto, como uma visão subjetiva e social da realidade (p.55). 
A representação social, entre as mulheres que fazem uso de métodos contraceptivos, pode ser entendida como um conhecimento prático que direciona suas ações e atitudes frente à regulação da sua fecundidade. Essas atitudes podem ser elaboradas, a partir das informações adquiridas junto aos profissionais de saúde; o conhecimento já existente do senso comum, fruto da sua própria vivência, ou informação e observação do grupo familiar; e finalmente através das trocas com seu grupo social, onde as informações circulam e sempre surgem novas formas de conhecimento.

MOSCOVICI (1985), diz que o senso comum corresponde à ciência como uma aparência do quotidiano. Não há como negarmos; cada evidência, cada afirmação do dia-a-dia esconde em sua própria banalidade, uma imensa quantidade de conhecimento, uma cultura condensada e um mistério, que constitui sua força motriz e atração.

Segundo SPINK (1993), os diversos autores, que lidam com as representaç̃̃es sociais, destacam algumas funções, enquanto fenômeno psico- social:

- Orientação das condutas e das comunicações (função social)

- Proteção e legitimação de identidades sociais (função afetiva)

- Familiarização com a novidade (função cognitiva)

$\mathrm{Na}$ função social é evidenciado o processo de negociação construtiva das relações sociais. O indivíduo, nessa perspectiva é sempre uma entidade social e, como tal, um símbolo vivo do grupo que ele representa. É ela, portanto, que propicia a abertura para se trabalhar o particular como expressão universal, através de estudos de caso social e historicamente contextualizado.

A função afetiva privilegia a interação social, mais especificamente, a elaboração de estratégias coletivas ou individuais.Esta interação se constitui na manutenção das identidades ameaçadas, em algo familiar, e torna o invisível em perceptível. 
A função cognitiva de familiarização com a novidade. Transforma o estranho- potencialmente ameaçador- em algo familiar, e permite evidenciar os processos de ancoragem e objetivação.

As representações sociais são elaboradas através e nas dinâmicas de comunicação. A comunicação é o veículo que permite a formação das representações, de modo que estas se exercem na regulação da dinâmica relacional entre os atores sociais.

NOBREGA (1990) e SPINK (1993) evidenciam os dois principais processos envolvidos na elaboração das representações, postuladas por Moscovici em 1961, a ancoragem e a objetivação, que compreendem a imbiricação e articulação entre a atividade cognitiva e as condições sociais em que são forjadas as representações.

A ancoragem refere-se à inserção orgânica do pensamento já construído, é a maneira na qual as informações novas são integradas e transformadas em conjunto de conhecimento socialmente estabelecido, ou seja: ancoramos o desconhecido em representações já existentes. A ancoragem é organizada sobre três condições estruturantes: o enraizamento no sistema de pensamento, a atribuição do sentido e a instrumentalização do saber. A ancoragem, portanto constrói-se na realidade social vivida, não sendo, por conseguinte, concebida como processo cognitivo intra- individual.

Para que o estranho seja familiarizado e dominado, os sistemas de pensamento, já estabelecidos, ou mesmo os mais arcaicos, tendem a predominar através dos mecanismos de classificação, de comparação e de categorização do novo objeto em julgamento.

A objetivação, por sua vez, é uma operação formadora de imagens, o processo através do qual noções abstratas são transformadas em algo concreto, quase tangível. A objetivação consiste em materializar as abstrações, corporificar os pensamentos, tornar físico e visível o impalpável, enfim, transformar em objeto o que é representado. Este processo também implica em três processos estruturantes: a descontextualização da informação, através de critérios normativos e culturais; a 
formação de um núcleo figurativo, e de uma estrutura conceitual; e a naturalização, isto é, a transformação destas imagens em elementos da realidade.

É ainda NOBREGA (1990), que cita Doise, dizendo que as duas dinâmicas, de objetivação e de ancoragem, são, aparentemente opostas: uma visa a criar as verdades evidentes para todos e independentes de todo determinismo social e psicológico, a outra designa, ao contrário, a intervenção de tais determinismos na sua gênese e transformação.

As mulheres elaboram suas representações sobre a esterilização, assim como de outros métodos, a partir das informações recebidas -função cognitiva - pois, para muitas, é a maneira de familiarizar-se com a novidade. Estas informações, por outro lado são recebidas do grupo social em que convive -função social - no sentido da orientação da conduta e das comunicações, que perpassam por este grupo social. $\mathrm{E}$, finalmente, a função afetiva - que privilegia a interação social. Estes fatores e que poderão figurar como marcos para a decisão de optar pela esterilização.

As representações sociais são produzidas pelas interações e comunicações no interior dos grupos sociais. Refletem a situação dos indivíduos no que diz respeito aos assuntos objetos do seu cotidiano. Uma representação, quando formada, influencia os comportamentos individuais face ao objeto representado.

Segundo MOSCOVICI (1985), quando estudamos representações sociais, o que estamos investigando são seres humanos que pensam, e não apenas manipulam informações ou agem de determinada maneira. Os indivíduos e grupos são qualquer coisa, menos receptores passivos, e que pensam de forma autônoma, constantemente produzindo e comunicando representações. As pessoas estão sempre fazendo colocações críticas, comentando e fermentando "filosofias" não oficias e espontâneas que têm influência decisiva sobre suas relações, suas escolhas, sua forma de educar as crianças, fazer planos e assim por diante.

Entretanto não podemos negar que as representações são imersas em um movimento contínuo das incessantes e infatigáveis ondas de comunicação. Elas circulam nos discursos e se materializam nas condutas. NÓBREGA (1990), enfoca a classificação de Moscovici, como três sistemas de indução das representações: a 
difusão, a propagação e a propaganda, que correspondem, respectivamente, à edificação das condutas de opinião, atitude e estereótipo.

Os meios de comunicação em massa tem sido de grande importância no processo de formação das representações. A difusão do modelo de família ideal baseada em posturas maltusianas, assim como as transformações ocorridas, oriundas da industrialização e difusão do modelo de vida urbana, que traz imbutido a idéia de família pequena - projeta a paridade por volta de dois filhos. O modelo de família pequena se disseminou, também, devido à urbanização ocorrida no Brasil nas últimas décadas, o que foi reforçado pela queda do poder aquisitivo das famílias.

Essas representações, propagadas pela mídia, certamente irão influenciar as mulheres no momento de fazer suas opções na área contraceptiva.

MINELLA (1998), analisa a representação da esterilização na fala de uma de suas entrevistadas: "Uma das investigadas, esterilizadas aos 32 anos e atualmente com 46 e três filhos, incorporou de tal forma a cultura da esterilização que defende que esse procedimento devia ser realizado nas mulheres pobres para diminuir a miséria e a pobreza e também os bandidos, e conclui, absolutamente convicta do seu ponto de vista, ela parece não se dá conta de que a diminuição da prole, por si só, não representa uma garantia de melhoria do padrão de vida se quer para si própria”(p.75)

A formação das representações sociais, no que diz respeito à contracepção, se dá a partir das informações recebidas do grupo social, da família, dos serviços de saúde, da mídia (principalmente televisa, acessível a todos os grupos sociais) e, também, dos sentimentos e valores individuais.

No nosso estudo, o objeto da representação -contracepção- é representado pelas mulheres, considerando que estas possuem informações e vivência sobre o referido objeto. A partir dessas representações, acontecerão as escolhas dessas mulheres quanto ao método contraceptivo, dentro do leque de opções que lhes são oferecidas, das quais tiverem acesso mais fácil, ou que considerarem mais seguro. 


\subsection{Cenário do estudo.}

O estudo ocorreu na cidade de Feira de Santana Bahia, com mulheres que fizeram ligadura de trompas em dois hospitais: o Hospital Público de Municipal e um Hospital Particular conveniado ao SUS, e também na Área 21 do Programa de Agentes Comunitários de Saúde (PACS).

Denominada "Princesa do Sertão", Feira de Santana, foi originada de uma rota de boiadeiros que vinham do alto Sertão da Bahia, Piauí e de Goiás. Localiza-se na divisa do recôncavo com o Sertão, ao leste do Estado, sendo ponto de passagem obrigatório da rota norte-sul do País, por se encontrar em um entroncamento de estradas.

Conforme o último Censo, o município possui uma população de 480 . 692 habitantes sendo 251.183 mulheres e 229.509 homens. Apresenta densidade demográfica de 359, $23 \mathrm{hab} / \mathrm{km}^{2}$ e taxa de crescimento anual de 1,64 (IBGE 2000).

A maioria da população está concentrada na zona urbana com 431.458 habitantes contra somente 49.239 habitantes da zona rural. É, por isso, o segundo município mais populoso do estado da Bahia.

Possui uma área geográfica de $1338.1 \mathrm{~km}^{2}$ e dista $108 \mathrm{~km}$. da capital do Estado, Salvador. Está situada na região centro-norte baiana à $12^{\circ} 16^{\prime}$ de latitude Sul e $38^{\circ} 59^{\prime}$ de longitude Oeste. Limita-se ao Norte com Candeal, Tanquinho e Santa Bárbara, ao Sul com São Gonçalo dos Campos e Antônio Cardoso; ao Leste com Santanopólis, Coração de Maria, Conceição do Jacuípe e Santo Amaro, e, a Oeste com Ipecaetá, Serra Preta e Angüera.

O Clima é sub-tropical, quente e úmido, com temperatura média anual de $27^{\circ}$ e umidade relativa do ar até $80 \%$ em alguns meses do ano. O período de chuvas vai de abril a setembro.

O perfil epidemiológico não difere muito da maioria dos municípios do nordeste brasileiro, onde encontramos doenças infecciosas, parasitárias e crônicodegenerativa (hipertensão, arterial, diabetes e neoplasias), assim como as de causas externas (homicídios e acidentes de veículos). 
A partir de 1997, segundo a determinação da Norma Operacional Básica (NOB-SUS 96), o município habilitou-se na Gestão Plena de Atenção Básica, tornando-se responsável pela gestão de assistência, bem como pelo atendimento básico à Saúde de sua população. Neste contexto, o gestor da saúde do município é o Secretário de Saúde que tem como responsabilidades organizar e desenvolver o Sistema Municipal de Saúde, identificando e priorizando as reais necessidades de saúde da população.

O município dispõe de uma rede de serviços de saúde composta por 37 unidades básicas de saúde, sendo 23 na zona urbana e 14 na zona rural. Dispõe ainda, de 101 políclínicas médico-odontológicas, 38 laboratórios de análises clínicas, 11 hospitais, incluindo 1 hospital geral, 1 hospital filantrópico, e 2 hospitais especializados. Dentre estes o Hospital Inácia Pinto dos Santos, também conhecido como "Hospital da Mulher".

\subsection{Sujeitos do Estudo}

Quando definimos quem seriam os sujeitos da pesquisa, delimitamos a mulher na faixa etária de 21 a 49 anos. O limite inferior foi estabelecido levando-se em consideração a maior idade civil da mulher. Quanto ao limite superior, consideramos a idade fértil da mulher. As mulheres, sujeitos da pesquisa, deveriam ser residentes em Feira de Santana, e terem realizado a ligadura de trompas em hospitais públicos e conveniados ao SUS.

Para viabilizar a coleta de dados foram encaminhados ofícios aos diretores dos hospitais da cidade explicando os objetivos do estudo e solicitando permissão para utilização do campo para o contato inicial com os sujeitos, alvo do estudo.Os Hospitais, Inácia Pinto( Hospital da Mulher) e Mater Dei, imediatamente permitiram a realização do estudo, facilitando o nosso acesso.

O Hospital da Mulher é uma instituição municipal e mantém convênios como setor privado. Presta atendimento às mulheres procedentes do município e da micro região de Feira se Santana, ofertando serviços ambulatoriais e hospitalares, e 
constituiu se em um dos campos de estudo. O Hospital Mater Dei é particular conveniado ao SUS. É um hospital geral com tradição de atendimento na área de ginecologia e obstetrícia contando, ainda, com ambulatório para atendimento de prénatal..

Ao iniciarmos a coleta de dados, tivemos alguma dificuldade em encontrar mulheres que tivessem realizado ligadura de trompas $O$ que muito nos intrigou. Se há tantas mulheres que optam pela esterilização na cidade, por que encontramos tão poucas? Foram as próprias entrevistas iniciais que nos esclareceram esta incógnita. As mulheres estavam migrando para duas cidades vizinhas onde as ligaduras são realizadas sem maiores dificuldades. Tentamos, então, fazer contatos com esses hospitais das cidades vizinhas. Todavia, não foi aceita a nossa presença para realização da coleta de dados, mesmo tendo informado de todo o anonimato e as questões éticas que seriam observadas. Resolvemos, então, realizar visita domiciliar direta, e buscamos ajuda junto ao PACS. Elegemos a unidade de saúde do bairro do Feira $\mathrm{X}$, onde já trabalhamos como campo de estágio dos alunos do Curso de Enfermagem. Entramos em contato com a enfermeira, gerente da unidade, e pedimos a colaboração dos agentes do PACS, que se constitui na área 21.

A área 21 do PACS é composta pelos bairros de Feira X, Mochila I e II, Viveiros, Três Riachos, Jussara e Loteamento São José. Abrange uma área bastante extensa, com população estimada em 13.828. habitantes, segundo dados da gerência do PACS.

Reunimo-nos com os agentes do PACS, onde fomos muito bem recebidos. Explicamos o objetivo do estudo, e solicitamos que, quando das visitas de rotina, caso verificassem que ali existiam mulheres que tivesse sido esterilizada há menos de 06 meses, falassem do estudo, e solicitassem a permissão e o consentimento para realização da entrevista. $O$ endereço daquelas que aceitassem, deveriam ser entregue na Unidade de Saúde, com ponto de referência. Ficou acordado que passaríamos periodicamente para recolhê-los e realizar a visita para realização da entrevista. 
Assim sendo, as mulheres, sujeitos da pesquisa, foram contatadas no Hospital conveniado, Hospital público municipal e nos bairros que fazem parte da região 21 do PACS na cidade de Feira de Santana.

As vinte entrevistas foram realizadas no período de setembro a dezembro de 2001. O número de entrevistas baseou-se no critério de saturação que segundo SÁ (1998), é entendido como o momento em que as informações obtidas começam a se repetir.

Como estabelecemos anteriormente que as mulheres deveriam estar com idade acima de 21 anos; no que diz respeito à faixa etária das mulheres entrevistadas encontramos: 02 entre 20 e 25 anos de idade (10\%); 06 com idade entre 25 e 30 anos (30\%); 09 na faixa etária entre 30 e 35 anos de idade (45\%); e 03 mulheres com idade entre 35 e 40 anos (15\%); considerando que a idade máxima das entrevistadas foi 37 anos de idade.

No que se refere à escolaridade das mulheres, encontramos: 04

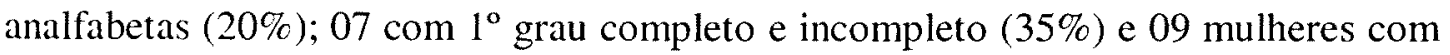
$2^{\circ}$ grau completo e incompleto $(45 \%)$.

\subsection{Instrumento de Pesquisa e Coleta de Informações.}

Para coleta de informações fizemos opção pela entrevista semiestruturada, por acreditarmos que é a técnica que melhor se adequa para alcançar o objetivo proposto pela pesquisa, por que de acordo com MINAYO (1994), a fala tem a possibilidade de ser reveladora de condições estruturais, de sistema de valores, normas e símbolos e ao mesmo tempo ter a magia de transmitir, através de um portavoz das representações de grupos determinados, em condições históricas, sócioeconômicas e culturais específicas (p. 111).

TRIVIÑOS (1992), privilegia a entrevista semi-estruturada porque, ao mesmo tempo que valoriza a presença do investigador, oferece todas as perspectivas possíveis para que o informante alcance a liberdade e a espontaneidade necessárias, enriquecendo a investigação. MINAYO (1994), entende que é onde se combinam 
perguntas fechadas (ou estreitar rodas) e abertas, onde o entrevistado tem a possibilidade de discorrer sobre o tema proposto sem repostas ou condições préfixadas pelo pesquisador.

As informações foram coletadas através de entrevistas realizadas pela própria pesquisadora.

As participantes da pesquisa foram contatadas nos hospitais, pela própria pesquisadora, e pelos agentes do PACS quando em seus domicílios. Quando consentidas, as entrevistas foram realizadas em domicílio, agendadas previamente. $\mathrm{E}$ quando as condições permitiam, foram realizadas no próprio hospital.

Em todas os contatos preenchia-se uma ficha de identificação (Anexo 1) contendo dados de identificação, endereço e algumas informações que julgávamos importantes.Este primeiro contato, que se deu com o preenchimento da ficha, serviu também como "quebra-gelo", uma abordagem inicial.

A todas as participantes do estudo foi apresentado o termo de responsabilidade do pesquisador (Anexo 2), e, assim, foi obtido o consentimento livre e esclarecido sendo asseguradas as condições de anonimato e sigilo, obedecendo aos critérios éticos, das Diretrizes e Normas Regulamentadoras da Pesquisa Envolvendo Seres Humanos, estabelecidos na Resolução 196/96 do Conselho Nacional de Saúde/Ministério da Saúde

Considerou-se que, em virtude da prática da esterilização comportar possibilidade de estigmatização e manifestação de preconceitos contra mulheres que realizam tal procedimento, assim como revelação de possíveis atos fora legalidade, não seja adequada a obtenção, neste tipo de pesquisa, do consentimento por escrito, mantendo-se o anonimato da entrevistada.

Foi elaborado um roteiro de três perguntas norteadoras para a realização das entrevistas.

1. Poderia me contar sobre sua história com as formas de evitar filhos?

2. Quando decidiu realizar a ligadura de trompas?

3. Você teve alguma informação sobre as vantagens e desvantagens da esterilização, por algum profissional de saúde? 
As entrevistas foram gravadas em fita cassete evitando, assim, a perda de informações importantes. A transcrição foi feita logo após a realização de cada entrevista, procurando, dessa forma, evitar perdas, e proporcionar familiarização com o texto. Cada entrevista recebeu um número, como uma forma de não identificar a entrevistada (Anexo 3 ).

\subsection{Procedimentos de Análise}

A análise dos depoimentos obtidos, a partir da transcrição das entrevistas, foi realizada com base no método da análise de conteúdo(BARDIN 1977).

Para BARDIN (1977), a análise de conteúdo é um conjunto de técnicas de análise das comunicações, e concrdando com Henry e Moscovici, considera que tudo que é dito ou escrito é susceptível de ser submetido a uma análise de conteúdo.Para o autor, o método se presta para o estudo das motivações, atitudes, valores, crenças e tendências. Seria, portanto, a análise do comportamento das pessoas contido em um texto, como no caso desse estudo, o texto das entrevistas obtidas com mulheres esterilizadas.

Ao conceituar a análise de conteúdo, o autor afirma ser:

Um conjunto de técnicas de análise das comunicações, visando obter, por procedimentos sistemáticos e objetivos de descrição do contelído das mensagens, indicadores (quantitativos ou não), que permitam a inferência de conhecimentos relativos às condições de produção/recepção (variáveis inferidas) destas mensagens (BARDIN 1977, p.42).

O objetivo da análise de conteúdo não se limita a observação da frequiência de que determinada idéia ocorre nos discursos, mas prevê o entendimento a partir do contexto em que as idéias foram geradas. Para VALA (1986), a finalidade da análise de conteúdo será, pois, efetuar inferências, com base em uma lógica explicitada, sobre as mensagens cujas características foram inventariadas e sistematizadas. Na visão de BARDIN (1977), a intenção da análise de conteúdo é a 
inferência de conhecimentos relativos às condições de produção (ou, eventualmente, de recepção) inferência esta que recorre a indicadores.

BARDIN (1977), assinala três etapas básicas no trabalho com a análise de conteúdo: pré-análise, descrição analítica, e interpretação inferencial.

Na fase de pré-análise, inicialmente fizemos várias leituras do material das entrevistas, tentando angariar familiaridade com os textos, buscando apreender seu conteúdo. Num segundo momento, a leitura do texto se deu de forma sistemática, assinalando ocorrências pertinentes à pesquisa. Constituindo-se assim, a fase analítica, em que o "corpus" é submetido a um estudo mais aprofundado (Anexo 4). Os procedimentos de unidades de registros, codificação e categorização são básicos neste momento. O passo seguinte se constituiu na formação dos temas que, de alguma forma, sintetizam as categorias e unidades de registro das entrevistas. E, finalmente procedeu-se à síntese das unidades de registro agrupando-as e categorizando-as.

Categorização é uma operação de classificação de elementos constitutivos de um conjunto. As categorias são rubricas ou classes as quais reúne-se um grupo de elementos (unidades de registro) sob um título genérico, agrupamento esse, efetuado em razão dos caracteres, como pertencentes a estes elementos (BARDIN 1977).

Para VALA (1986), a construção do sistema de categorias pode ser feita, a priori ou a posteriori ou, ainda, através da combinação desses dois processos.

No caso deste trabalho, as categorias foram estabelecidas com base nas entrevistas realizadas. Portanto, são categorias empíricas, realizadas a posteriori.

Categorias empíricas são construídas a partir do trabalho de campo. Elas têm a propriedade de apreender as determinações e especificidades que se expressam na realidade empírica (MINAYO 1994).

A interpretação das informações foi elaborada pela inferência, que se constitui na terceira etapa. Neste momento, as deduções obtidas, através das entrevistas, vão estabelecer uma relação com o conhecimento já acumulado 
anteriormente, com o referencial teórico que embasa a pesquisa, os objetivos e idéias norteadoras do trabalho.

Finalmente, a análise dos dados coletados com o objetivo de identificar os motivos que levam as mulheres a buscar a esterilização como método contraceptivo, foi realizada segundo a técnica de análise categorial, que funciona por desdobramento do texto em categorias, e unidades temáticas definidas empiricamente.

Os temas e categorias foram listados da seguinte forma (Anexo 5)

\begin{tabular}{|c|c|}
\hline TEMAS & CATEGORIAS \\
\hline $\begin{array}{l}\text { Tema I - Dificuldade no uso da } \\
\text { pílula. }\end{array}$ & $\begin{array}{l}\text { - Pílula inadequada } \\
\text { - Falta de confiança na pílula } \\
\text { - Uso incorreto da pílula } \\
\text { - Efeitos colaterais da pílula } \\
\text { - Falta de informação sobre o uso da pílula } \\
\text { - Impossibilidade no uso da pílula }\end{array}$ \\
\hline Tema II - Medo do DIU & $\begin{array}{l}\text { - Efeitos colaterais do DIU } \\
\text { - Insegurança no uso do DIU } \\
\text { - Falta de informaçóes no uso do DIU }\end{array}$ \\
\hline $\begin{array}{l}\text { Tema III - Dificuldade com } \\
\text { outros métodos }\end{array}$ & $\begin{array}{l}\text { - Inadequação com a camisinha } \\
\text { - Inadequação com o coito interrompido } \\
\text { - Inadequação com a tabela } \\
\text { - Efeitos colaterais dos injetáveis } \\
\text { - Irregularidade na distribuição de métodos }\end{array}$ \\
\hline $\begin{array}{l}\text { Tema IV - Satisfação com a } \\
\text { prole }\end{array}$ & $\begin{array}{l}\text { - Número de filhos } \\
\text { - Condições sócio-econômicas }\end{array}$ \\
\hline $\begin{array}{l}\text { Tema } V \text { - Informação sobre } \\
\text { contracepção }\end{array}$ & $\begin{array}{l}\text { - Falta de acesso ao planejamento familiar } \\
\text { - Informação equivocada } \\
\text { - Acesso à esterilização } \\
\text { - Segurança na esterilização }\end{array}$ \\
\hline
\end{tabular}




\begin{tabular}{|c|c|}
\hline $\begin{array}{l}\text { Tema VI - Informação sobre } \\
\text { esterilização }\end{array}$ & $\begin{array}{l}\text { - Falta de informação sobre esterilização } \\
\text { - Número de cesáreas } \\
\text { - Fonte de informação sobre esterilização } \\
\text { - Sintomas após esterilização } \\
\text { - Insegurança com a técnica de esterilização }\end{array}$ \\
\hline Tema VII-Outros & $\begin{array}{l}\text { - Parto difícil } \\
\text { - Falta de colaboração do companheiro } \\
\text { - Pressão Familiar } \\
\text { - Pressão Social } \\
\text { - Aborto provocado }\end{array}$ \\
\hline
\end{tabular}

A apresentação das categorias de respostas será acompanhada dos trechos das entrevistas. Partindo do princípio de que todas as falas são importantes, estas foram categorizadas, mesmo quando apresentavam baixa freqüência.

Os textos extraídos das transcrições das entrevistas, ao final, foram numerados entre parênteses. Isso permitirá a recuperação no texto da unidade de registro (Anexo 4) assim como no texto de temas e categorizações (Anexo 5). 


\section{OS MOTIVOS QUE LEVARAM À ESCOLHA DA ESTERILIZAÇÃO COMO MÉTODO ANTICONCEPCIONAL}

\subsection{Dificuldade no Uso da Pílula}

A pílula, por estar entre os métodos com maior freqüência de uso para contracepção entre as mulheres, apresenta, ainda dificuldades no uso, às vezes por falta de orientação, e às vezes por apresentar problemas quanto à falta de inocuidade.

As principais dificuldades, quanto ao uso desse método, e sua rejeição pelas mulheres que optaram pela ligadura tubária, serão relatados a seguir:

\section{Pílula Inadequada.}

Algumas entrevistadas fazem referência de ter engravidado com uso da pílula, e alegam que o fato ocorreu devido à pílula ser "fraca". Essa mesma queixa pode ser observada em alguns relatos:

"O anticoncepcional eu tomei, passei três anos tomando e por uma falha eu engravidei, acho que foi o remédio mesmo que já estava fraco" (1.2)

"Eu estava amamentando a menina e tomando o micronor, só que o micronor estava ficando fraco, e eu não mudei e aí engravidei." (2.1)

As chamadas micro-pílulas, com dosagens cada vez menores de hormônio ou, mesmo, as pílulas exclusivamente de progestágeno que, aparentemente, eram utilizadas nos dois casos, exigem maior regularidade no seu uso, para que o hormônio se mantenha em níveis compatíveis com vistas à maior eficácia no efeito contraceptivo. Carece, também, de orientação específica no seu uso, pelos profissionais de saúde, visto que diferem dos outros anticoncepcionais quanto ao início de uso $\left(1^{\circ}\right.$ dia do ciclo menstrual), quanto a cuidados mais específicos no sentido de horários mais rigorosos. (SECRETARIA DE SAÚDE DO ESTADO DA BAHIA 1998). 
O acompanhamento profissional, para as devidas orientações e avaliação da saúde da mulher, é uma forma de evitar o uso da pílula de forma inadequada. $\mathrm{O}$ MINISTÉRIO DA SAÚDE (1992) recomenda que no manejo da pílula, um primeiro retorno deveria ser feito após o primeiro mês de uso, e, depois, de três em três meses para avaliação das repercussões do medicamento no organismo da mulher.

\section{Falta de Confiança na Pílula}

A Pílula apresenta taxa de falha muito baixa, quando se considera seu uso correto, é de 0.1 a 0.8 gravidezes por 100 mulheres durante o primeiro ano de uso (SECRETARIA DE SAÚDE DO ESRADO DA BAHIA - 1998).

Mesmo considerado um dos métodos anticoncepcionais de maior eficácia, algumas mulheres demonstram falta de confiança na pilula:

\footnotetext{
"Eu penso assim, se eu continuar tomando remédio um dia vai falhar" (1.8)
}

"Era para eu ficar com dois filhos, o último eu peguei com remédio, esse neovular, a menstruação estava vindo antes de acabar o comprimido... Quando fica assim é que não estava dando mais". (5.6)

Aparentemente estamos, outra vez, diante da questão da falta de orientação, o que se percebe, nessa fala, é que a mulher usa um determinado anticoncepcional, sofre alguns efeitos colaterais, e não lhe é oferecida a opção de troca do medicamento.Esta ocorrência faz com que ela passe a acreditar que não há mais condição para o uso da pílula. Isso mostra a necessidade de maiores esclarecimentos para que o método seja encarado com mais segurança. O que fica muito claro na fala da entrevistada:

"Aí eu decidi ligar, porque evitar com remédio podia falhar, né?" (17.4) 
A falta de confiança na pílula, geralmente, é referida pela entrevistada quando da ocorrência de gravidez indesejada (dela mesma), ou de informações recebidas, por meio do seu grupo social, de fatos semelhantes ocorridos com mulheres em uso de pílula. Conceitos tais, fundamentados no senso comum, é que contribuem na formação de uma representação negativa do método.

\section{Uso Incorreto da Pílula.}

A referência mais constante, da forma incorreta no uso da pílula, é o esquecimento. Como já foi dito, anteriormente, a regularidade é um fator preponderante para a eficácia contraceptiva. O esquecimento, por sua vez, compromete essa eficácia, principalmente nas pílulas com baixos teores hormonais. São freqüentes os relatos de esquecimento, ou de uso incorreto como podemos verificar:

"Depois eu comecei a usar a pílula, só que eu era muito esquecida, eu tenho quatro filhos, e todos são fruto do esquecimento, eu esquecia mesmo. A gente tem costume de dizer Ah! A pílula falhou, mas não era que falhava era que eu realmente esquecia" (3.2)

"Eu tomava comprimido desde o primeiro, eu errava o horário ou o dia... a gente se esquece, aí aparece grávida sem querer. Aí eu engravidei de cinco filhos, mesmo tomando pílula" (10.1)

"Eu tomava pílula. Aí, eu tomei anticoncepcional e sempre parava quando a menstruação chegava. Aí eu não sei se eu esquecia de tomar alguns comprimidos, só que eu muito fértil... eu fiquei grávida tomando, isso aí eu tenho absoluta certeza" (19.1)

A falta de orientação, no uso da pílula, leva ao uso incorreto do método. SILVA e cols (1990) concluíram, em seu estudo, que entre mulheres que faziam uso do método hormonal, uma grande parte o fazia, por mais de cinco anos, sem receber 
informação, sem o devido acompanhamento profissional. A falta de orientação sobre o uso da pílula se reflete nas falas das entrevistadas da seguinte maneira:

"Tomava remédio: sempre tomei. Eu engravidava por que não tomava o remédio certo..." (14.1)

"Eu tomava remédio, mas não me dava e aí tomava dia sim, dia não, até quando engravidei da primeira filha" (16.1)

Para CARVALHO (2001), o esquecimento constitui-se em uma estratégia utilizada pelas mulheres para lidar com o conflito, entre interromper o uso da pílula e o medo de engravidar. Este esquecimento pode estar diretamente ligado à não tolerância aos efeitos colaterais.

\section{Efeitos Colaterais da Pílula}

Embora o anticoncepcional hormonal oral,seja o que apresenta uso mais frequente entre as mulheres, apresente uma excelente eficácia e baixa probabilidade de falha, a referência de efeitos colaterais compromete, muitas vezes, o uso e a eficácia do método.

Para HOGA (1996) as mulheres que tomam pílula anticoncepcional e acabam deixando de usar esse recurso para evitar filhos, fazem-no em razão de vários sintomas orgânicos que aparecem, que as próprias mulheres avaliam como sendo prejudicial a sua saúde, ou lhes representam um sinal de alerta, de que algo em seu organismo não está bem.É quando tomam a decisão de abandonar o uso do recurso anticoncepcional. Esta questão fica bem evidente nestas falas:

"Eu logo quando casei, comecei a tomar anticoncepcional Aí com dois anos e meio por ai eu parei porque tive um problema de inflamação, essas coisas, aí eu parei o remédio”. (4.1) 
"Tive[um filho] em novembro. Quando foi em janeiro fiz revisão, aí já pedi o anticoncepcional prá tomar. Tomei durante onze anos. Só que durante esse tempo começou a sair uma mancha vermelha no corpo" (4.3)

"Sempre usei pílula, aí comecei a usar aquele microvilar; aí fiquei muito mal: comecei a emagrecer, perder apetite, aí passei a usar o Nordete não senti bem também, aí passei..." (5.1)

"Eu usava tabelinha, depois comecei usar anticoncepcional, mas começou a me dar dor no estômago... O médico suspendeu e me falou para usar a camisinha, e fazer exame prá saber, e se é com todos os anticoncepcionais, por que algum anticoncepcional poderia não dar." (13.1)

"No começo eu tomei pílula durante três anos, depois do primeiro filho. O filho mais velho tem 09 anos, o outro 8 e o outro 7, depois do de sete anos eu coloquei o DIU. Com a pílula eu sentia enjôo." (15.1)

"Tomava hoje amanhã não tomava por que vomitava, enjoava, com dor de cabeça e sentia mal, parecendo que ia desmaiar, ai fazia assim um dia tomava e outro não, ficava tomando assim achando que evitava filho... com a segunda foi a mesma coisa, ai engravidei da segunda e disse: dessa daqui agora vou ter que ligar." (16.2)

"Porque o anticoncepcional mesmo só me dava dor de cabeça, Até hoje eu tenho problema de nervoso e acho que causado por ele. Sempre eu trocava de remédio."(19.4)

O MINISTÉRIO DA SAÚDE (1996), propõe a rotina para o atendimento no uso de todos os métodos contraceptivos e preconiza que, no caso de interrupção de um método outro método deve ser garantido para evitar a gravidez indesejada. 
Na visão de CARVALHO (2001) o atendimento recebido por algumas mulheres parece evidenciar algum grau de despreparo técnico de profissionais para o manejo da pílula, o que acaba por determinar a sua suspensão, sem a substituição por outro método alternativo, e a questão devidamente discutida, e principalmente viabilizada.

“O médico falou para eu mudar, que o remédio estava fraco. Mas só que eu fiquei com medo, porque os anticoncepcionais têm muito hormônio $e$ eu fiquei com medo de passar para menina." (2.6)

"De um filho para o outro foram quase 12 anos tomando anticoncepcional... Agora o problema apareceu e eu fiquei quase 3 anos com esse problema tentando descobrir..." (4.8)

"[...] antes de engravidar do primeiro menino, eu nunca tomei nada. Tive ela e fiquei amamentando... Fui ao médico e ele passou um remédio e disse que, mesmo amamentando eu ia menstruar,.... Depois comecei a tomar remédio de novo. Quando parei, eu tomava a "femina" ai comecei a sentir mal, pressão baixa, aí o médico mandou parar um pouco, (6.1)

“Ele sugeriu, ir evitando, tomar o remédio mesmo, usar a camisinha, mas no meu caso não comecei a passar bem com as pílulas." (6.9)

"Eu sempre usei remédio de evitar, o microvilar ai comecei sentir enjôo... suspendi porque o médico disse que minha pressão estava subindo muito." (12.1)

"Aí eu mudei para um outro que era importado, e tinha lá no posto. Eu não sentia dor, mas optei por não mais usar, porque não gosto, $e$ também por problema de pele, eu já tenho uma pele ruim (manchas) e o anticoncepcional é uma maravilha para manchar a pele ai parei e fiquei com a tabelinha." (13.2) 
"[...]a médica, que até faleceu, ela proibiu eu tomar anticoncepcional porque sempre tive varizes e me incomoda muito: até hoje me incomoda." (19.2)

Alguns estudos demonstram a preocupação de seus autores no que se refere aos efeitos colaterais da pílula, assim como a sua absoluta contra indicação (HARDY e cols. 1991; CESAR e cols. 1993; CASANI e cols. 1994).

Os efeitos colaterais mais observados ou referidos, pelos entrevistados no estudo de CASANI e cols (1994), foram: aumento de peso, seguido de cefaléia, alterações do humor, náuseas e vômitos. Ainda foram referidos sangramento intermitente e diminuição da libido.

No estudo de CARVALHO (2001), os efeitos colaterais referidos, pelas 31 mulheres entrevistadas, foram: náuseas e vômitos, dor de cabeça e enxaqueca, dor de estômago e azia, mal estar, tonturas, irritação e nervosismo, alterações hormonais, aumento de peso, pressão alta, varizes, dor nas pernas e diminuição da libido.

A assistência preconizada pelo MINISTÉRIO DA SAÚDE (1992), prevê, para o início do uso da pílula que se faça a análise de contra indicação do uso do método, e de interação com outros medicamentos que a mulher esteja em uso. Estabelece, também, que se proceda a orientação sobre os possíveis efeitos colaterais de maior gravidade como: trombose, hipertensão arterial e hepatopatias.

Como se pôde observar, nos trechos das entrevistas, o abandono do método acontece por aparecimento de efeitos colaterais considerados pelos profissionais de saúde como sendo de menor gravidade, mas que devem ser informados à mulher que deseja fazer uso de pílulas. Os efeitos mais referidos na literatura são: irritabilidade, náuseas, vômitos, mal-estar gástrico, dor de cabeça, tonturas, dor nas mamas, sangramento intermenstrual, manchas na pele entre outros.

Importante, portanto, é o acompanhamento e atendimento individualizado dessas mulheres nos serviços de saúde, a fim de identificar e discutir com a mulher, esses desconfortos, na tentativa de adequação ao método.

Mas, a realidade parece se apresentar de outra forma CORREA e PETCHESKY (1996) acreditam que há uma postura comum de profissionais de saúde que desconsideram a queixa das mulheres quanto aos efeitos colaterais da 
pílula, como se estes fossem "esperados" ou de pouca importância. Talvez esse desrespeito esteja sendo enfrentado com igual desconsideração das mulheres, em relação às orientações fornecidas por esses profissionais.

HARDY e cols (1991), chamam a atenção dizendo que só algumas pesquisas mais recentes têm-se preocupado em verificar se as usuárias apresentam algum fator que contra indique o uso da pílula, e concluem: o que seria de se esperar, já que a maior parte delas, não está sob controle dos serviços de saúde, limitando-se a adquirir a pílula diretamente na farmácia.

\section{Falta de Informação sobre o Uso da Pílula}

Como vimos, anteriormente, a falta de informação segura, sobre o uso de pílula, e a simples aquisição sem orientação, aumentam a incidência de efeitos colaterais. Da mesma forma, a falta de avaliação dos fatores de risco que possam existir, quando da opção do uso de anticoncepcional hormonal e a falta de informação, ficam claras nas falas das entrevistadas:

"Sempre usei por minha cabeça mesmo... Quando sentia que estava mais fraco, o remédio, eu ia trocando por minha cabeça mesmo." (5.2)

"O remédio, eu comprava na farmácia, não era passado por médico" (14.4)

"Tomava remédio por minha cabeça não tive orientação de ninguém" (16.5)

Embora tenha uma tendência a acreditar que as mulheres, que adquirem a pílula anticoncepcional diretamente na farmácia, tenham maior chance de apresentar efeitos colaterais com o seu uso, HARDY e cols (1991) encontram, em seu estudo, 40\% das usuárias de pílulas que apresentavam fatores de risco para o uso do método. E afirmam: a primeira reação, ao constatar essa situação, é atribuir a má indicação do método ao fato de que, como já se disse, a principal fonte de prescrição e obtenção 
de pílula é a farmácia. Foi, porém, desencorajador observar que nem a indicação inicial do método por um serviço de saúde, nem o fato de obtê-lo nesse local faziam alguma diferença quanto à porcentagem de usuários com fatores de risco.

\section{Impossibilidade no Uso da Pilula.}

Para BACHA (2001) muitos dos medicamentos anticonvulsivantes aumentam o metabolismo hepático dos anticoncepcionais orais, restando duas possíveis soluções quando esse foi o método escolhido: optar por drogas, que não afetam o nível sérico dos anticoncepcionais orais, ou utilizar anticoncepcionais com $50 \mathrm{mg}$ de etinil-estrodiol ou mais.

O que não é observado na fala da entrevistada:

“[...] E a pílula eu não posso tomar, porque tomo gardenal. Aí engravidei do neném..." (9.2)

Portanto, quando bem orientada, embora faça parte do grupo de risco, a mulher que faz uso de medicamentos anticonvulsivante não está impedida de usar pílula ou adotar outros métodos anticoncepcionais.

É, ainda, BACHA (2001), quem recomenda que as pacientes, com crise epilépticas de difícil controle, poderão, se beneficiar da utilização de progestágenos de depósito. Parece que esse medicamento atuaria aumentando o limiar de convulsão, facilitando o controle da doença.

As conclusões do estudo de MELO et al.(1999), é de que, os contraceptivos orais, devem ser usados com bastante cuidado, nas mulheres epilépticas por apresentar maior número de falhas, pela interação medicamentosa; já os injetáveis trimestrais, representa alternativa benéfica, devido ao tempo de ação prolongada e por diminuir a ocorrência das crises convulsivas.

Ao analisarmos o método mais conhecido, e referido como método contraceptivo de mais frequente uso entre as mulheres, as várias falas revelam uma gama significativa de motivos que causaram a interrupção. Estes motivos vão desde a dificuldade no uso, por falta de entendimento de como usá-las; à falta de confiança 
no método, por ouvir de outras ou vivenciar, em algum momento a falha do mesmo; à falta de orientação segura para que o seu uso não caia em incorreções, como as citadas nas falas das mulheres entrevistadas, e os efeitos colaterais que dificultam o uso, às vezes, por ter sido mal indicado, desde o início. A reunião desses motivos, podem levar a mulher a buscar métodos mais definitivos.

MARCOLINO (1994) ao analisar a fala de suas entrevistadas, chega à conclusão a respeito do uso da pílula, que, a difícil convivência com a pílula verbalizada pelas mulheres, possibilitou entender como a ação diária da contracepção é uma experiência difícil para mulher levando-a ao abandono da pílula, partindo para um método mais radical como a esterilização cirúrgica.

\subsection{Medo do DIU.}

O Dispositivo Intra Uterino é um dos métodos que apresentam pouca aceitabilidade entre as mulheres. Este fato foi, também, observado e expresso nos estudos de MARCOLINO (1994); HOGA (1996) e CARVALHO (2001).

A representação negativa, que as mulheres têm do DIU, vão sendo captadas no decorrer de suas vidas, por informações recebidas através do seu meio social, da imprensa, e dos profissionais de saúde; provoca um sentimento de rejeição que são por elas expressado e avaliados sobre o aspecto de:

\section{Efeitos Colaterais do DIU.}

Os efeitos colaterais ou complicações clínicas são revelados nas falas. Com relação ás complicações que podem advir de sua utilização, existe o temor de que, de alguma forma, ou em algum momento venha a prejudicar sua saúde. $O$ que às vezes nem é explicitado:

“[...] Falou também que eu podia usar o DIU, mas fiquei com medo porque, geralmente, as mulheres não se dão bem com o DIU e aí eu achei melhor não colocar..." (2.10) 
"Ah! Eu conheço o DIU, mas minha irmã teve problema com o DIU e não quis" (3.13)

"Depois que eu tive a primeira filha minha mãe queria botar o DIU. Só que minha mãe, depois, ficou com medo de botar o DIU e sair do lugar, e dá problema no meu útero..."(8.5)

“Eu casei com 16 anos, logo engravidei do primeiro. Ai eu usei o DIU por 05 anos, aí o DIU ficou fora, ai minha família mandou botar de novo, ai eu não pude colocar por que eu estava perdendo muito sangue..." (9.1)

“Botei o DIU... comecei a sentir também a menstruação vinha e saia os bolos, ai eu voltei ao ginecologista de novo e ele disse que eu não poderia usar o DIU, que estava inchando o meu útero, ai eu peguei e tirei o DIU." (12.2)

"[...] tem gente que se não se dá. Aí eu não quis botar também” (14.9)

“Aí botei o DIU, depois não me dei também tirei, eu estava sangrando demais no período que botei o DIU, foram quatro anos, e quatro anos de sangramento." (15.2)

Os efeitos colaterais mais comuns que são relatados com o uso do DIU são: o aumento do fluxo menstrual, cólicas, amenorréia, fios perdidos e corrimento vaginal (com suspeita de DIP - Doença Inflamatória Pélvica).

A hemorragia é uma das queixas mais comuns e pode ser indicada a retirada do DIU, no caso de sangramento excessivo que possa comprometer a saúde da mulher (MINISTÉRIO DA SAÚDE1992).

A presença anterior de anemia contra-indica o uso do DIU, assim como também o aparecimento da anemia, após um período de uso do DIU, e é recomendada a sua remoção e conseqüente utilização de outro método. 
MARCOLINO (1994), citando Connell, afirma serem as cólicas, e aumento do sangramento, os dois efeitos colaterais mais comuns que ocorrem com o uso do DIU. São também, os responsáveis pelo maior número de remoções que varia de $4,0 \%$ a $14,7 \%$.

Para CARVALHO (2001) há uma certa subjetividade na avaliação deste efeito colateral, uma vez que o profissional de saúde depende, principalmente, do padrão da própria mulher para avaliar uma possível hemorragia (fluxo e duração aumentada).

Além do medo, as mulheres elaboram um imaginário sobre o DIU como sendo algo que elas não conhecem. Esta representação acaba por promover a insegurança, uma vez que acreditam que vão se sentirem invadidas por algo que não conhecem, o que, de alguma forma as perturba.

\section{Insegurança no Uso do DIU.}

A diversidade de referência negativas, associadas à absoluta falta de exemplo de mulheres que se sintam satisfeitas, utilizando o DIU, leva as mulheres à não querer optar por esse recurso para evitar filhos (HOGA, 1996). As nossas entrevistadas, também apresentam resistência ao uso do DIU.

“Eu não queria usar o DIU” (1.9)

“Uma médica falou, porque você não para os remédios e faz o DIU prá ver?Mas eu já estava no pensamento de parar o remédio, e quando engravidei resolvi ligar...." (4.9)

"Quando tive a menina, quiseram colocar o DIU..., só que me senti tão mal que eu fiquei com medo, mais uma dor... não quero não, e já colocava no outro dia mesmo, aí não quis, ai depois tinha que ir para o planejamento familiar eu fui relaxando e passou. Mas já estava decidido se a médica não ligar eu vou colocar o DIU. (6.10) 
"Ofereceram pra mim o DIU, mas eu tinha cisma, sei lá, sinto que tenho uma aparelho diferente dentro de mim, e nunca usei não...." (10.3)

"DIU? Eu tenho medo" (16.7)

"Eu não quis botar o DIU, me dava medo botar o DIU, sei lá, Acho que ia me prejudicar e tinha gente que falava que o DIU faz correr muito".(19.5)

A representação do DIU, como um corpo estranho, é um dos argumentos de que as mulheres se valem para rejeição do método. Talvez seja este um dos motivos que estimulam o medo do DIU por algumas mulheres. Um outro aspecto, a ser valorizado, é que as informações são mais efetivas, por parte do grupo de convivência do que aquelas recebidas dos profissionais de saúde. Há, ainda, a circulação das informações como a saída não percebida do DIU: considerada como "sumiço" no corpo, assim como de engravidar em uso do DIU. Com tantas representações negativas, o método acaba tendo um alto índice de rejeição, em nossa realidade.

SUDBRACK (1994) revela, em seu estudo, que há uma unanimidade, entre as mulheres, em recusar o DIU. Na vila onde se realizou o referido estudo, foi muito raro que aparecesse uma mulher que utiliza ou tenha utilizado o DIU.

\section{Falta de Informação no Uso do DIU}

Uma das causas responsáveis, pela pouca utilização do DIU, é a falta de informação sobre a frequiência que se deve voltar ao Serviço de Saúde para acompanhamento do método. Vejamos estes discursos:

"O DIU, eu vou ter que controlar, é aquela coisa de exame de seis em seis meses" (13.12) 
"Ouvi falar em DIU, botar o DIU tem que estar todo mês no hospital" (14.8)

$\mathrm{Na}$ visão das mulheres entrevistadas, a necessidade de retornos constantes, que demandam em espera de consultas, pode ser considerada como obstáculo para uso do método, principalmente quando o atendimento se traduz na perda de um período do dia, seja para marcação de consulta, por falta de vaga ou atendimento que não satisfaz as suas expectativas. Principalmente para aquelas que trabalham, isso se traduz em transtorno para sua vida. Acabam, portanto, optando pelo uso da pílula, até a espera do método mais definitivo - a ligadura de trompas.

Não se pode esquecer que, quando do uso do DIU, o controle não é só da alçada da mulher. É uma tarefa que envolve terceiros, pois, o DIU, só é colocado no Serviço de Saúde, por médicos. A colocação, normalmente, requer que a mulher esteja no seu período menstrual o que acarreta certa inibição. A retirada também não está sob controle só da mulher: ela necessita voltar ao Serviço de Saúde para fazê-lo. Durante o tempo de uso ela não o visualizava, não o controla, talvez esse fato contribua para tantas informações distorcidas, e para uma representação tão negativa do método.

\subsection{Dificuldades com Outros Métodos}

Se, por um lado, a pílula anticoncepcional acarreta, às mulheres, efeitos colaterais e sintomas que perturbam o seu bem estar e dificuldade no seu manejo, por outro, sendo, o DIU o método rejeitado por muitas mulheres, elas partem em busca de opções diversas que, na maioria das vezes, decorrem do conhecimento de experiência de outras mulheres no seu próprio meio. Este quadro acaba provocando muitas restrições, e também, abandono desses métodos pelas dificuldades que se apresentam. 


\section{Inadequação com a "Camisinha"}

Geralmente, a dificuldade no uso da condom (camisinha) é do homem. Vários autores relatam essa rejeição, por parte da maioria dos homens; principalmente quando se trata de utilização com parceira fixa (SUDBRACK 1994; MARCOLINO 1994; OSSIS 2001 e CARVALHO 2001).

No caso de nossas entrevistadas, a rejeição observada é das próprias mulheres: Podemos inferir que, ao assumir essa rejeição a mulher esteja tentando preservar o companheiro já que, habitualmente, o homem se coloca na posição de não usar. Aparentemente o uso do condom se dá como um recurso que é utilizado para ir contornando a situação enquanto não se pode fazer uso de outros métodos.

"Primeiro usei camisinha, achava muito chato" (3.1)

"[...] e fiquei usando camisinha, acho que nesse usar de camisinha deve ter falhado." (6.2)

"Ai levei três meses usando camisinha ai eu vi que não dava certo, ai eu fui e fiz o tratamento e liguci." (12.3)

"Eu sabia de outros métodos e não gostava e não gostava. Camisinha eu não quis,..."(16.6)

CARVALHO (2001) comenta também, em seu estudo, a questão da rejeição à "camisinha" quando diz ter observado que a rejeição do condom, não é monopólio masculino. Entende, ser devido à representação de que o uso do preservativo é definido como uma modalidade de relação sexual que pode ser considerada como "diferente do normal".

O receio de falha, abordado pelas entrevistadas, é também uma das causas da rejeição, o que sempre é possível devido à possibilidade de rompimento, ou incorreção do uso. 
Para SUDBRACK (1994), não há, tradicionalmente, o hábito de utilização do preservativo em uniões estáveis. No imaginário social, esta prática existe mais em função do sexo praticado "fora de casa," no intuito de prevenir doenças, ou impedir gestações indesejadas.

\section{Inadequação com o Coito Interrompido}

$\mathrm{O}$ método do coito interrompido é muito conhecido e adotado pelas mulheres.

Popularmente é conhecido como "método normal", o de "gozar fora", "tirar pra fora na hora" ou "não deixar o homem deixar dentro" (HOGA 1996).

CARVALHO (2001) informa que o coito interrompido é um dos métodos temporários mais usados no mundo, sendo adotado por $13 \%$ dos usuários de métodos. No estudo da referida autora a freqüência foi bastante alta $(55 \%)$, no intervalo de uso entre outros métodos como, pílulas, injetáveis ou DIU.

Em nossa pesquisa houve apenas uma referencia ao coito interrompido, mas que já tinha sido rejeitado:

"Cheguei a fazer coito interrompido, mas não deu." (3.14)

Talvez a maior rejeição a esse método seja por sua baixa eficácia e desconforto dos parceiros. Toda a responsabilidade do controle recai sobre o homem, e quando não há a sua colaboração, o uso do método fica impossibilitado, pela absoluta falta de controle da mulher.

\section{Inadequação com a Tabela}

O método da tabela é muito conhecido, mas de pouca utilização entre as mulheres entrevistadas. A procura por este método restringe-se a poucas mulheres que lhe dão crédito. 
Para HOGA (1996) a recusa na utilização do método da tabelinha relaciona-se à dificuldade de acesso a informações corretas sobre o seu modo de funcionamento. Isso acarreta a falta de compreensão sobre o seu uso.

A pouca facilidade de uso do método aliado a suas constantes falhas, leva a uma representação negativa do mesmo.

Para CARVALHO (2001), vários são os motivos que levam à baixa eficácia do método de tabela. A margem de falha que o próprio método apresenta, a falta ou a orientação inadequada sobre o uso, são alguns exemplos.Aliem-se a isso, a terapia hormonal, que altera o ciclo ou simplesmente a dificuldade do casal, em manter a abstinência nos dias férteis, são fatores que, isolados ou reunidos, contribuem para ineficiência do método.

Encontramos apenas uma referência ao uso da tabela.

“ fiz tabela também, mas fazia errado também." (14.2)

E, ainda, HOGA (1996) que acredita ser a insegurança demonstrada pelas mulheres em sua própria capacidade de aprendizado, que facilita à falta de credibilidade na eficácia do método.

Embora pareça simples, o método da tabela necessita que a mulher conheça a sua fisiologia reprodutiva, observação do seu ritmo corporal, e ciclo menstrual. Como este desconhecimento é mais verificado entre mulheres, com escolaridade e nível sócio-econômico baixos, aparentemente, estes aspectos fazem com que a dificuldade, quanto ao uso do método, seja aumentada.

Outro dificultador, para o uso do método é a necessidade da abstinência sexual nos dias férteis, exigindo o uso de outros métodos combinados.

\section{Efeitos Colaterais dos Injetáveis}

Os anticoncepcionais hormonais injetáveis têm uma vantagem de substituir a dose diária de anticoncepcional hormonal oral, facilitando, dessa forma, o seu uso. Entretanto, podem, apresentar efeitos colaterais, dentre eles a irregularidade 
do ciclo menstrual, que se manifesta, desde o aumento do fluxo ao quadro de amenorréia (MINISTÉRIO DA SAÚDE 1996)

A resistência ao uso do anticoncepcional injetável, ocorre, principalmente em função das complicações e efeitos colaterais que seu uso pode causar.

“[...] também, não queria usar a injeção; porque a minhas colegas lá tem umas três que usam injeção... E minha prima usa a injeção direto $e$ sempre tem problema. Eu fiquei com medo, ela sempre tem problema." $(1.10)$

"Camisinha eu nunca usei, tentei a injeção de 01 mês, mas eu menstruava duas no mês, aí tentei com a de 06 meses, custava até 20 e poucos reais, ainda tomei umas 03 , mas menstruava no primeiro mês. Aí, voltei a tomar comprimido, aí foi que decidi ligar." (10.4)

A associação de alterações orgânicas, ou menstruais, reforça a representação de que usar a injeção "dá problemas", que muitas vezes é identificada com o método. Outro aspecto interessante é o medo de não poder mais suspendê-lo, visto que a duração de um ou três meses forçaria a mulher, que apresentasse efeitos colaterais, a suportá-lo até o fim do seu efeito. Diferentemente do anticoncepcional oral que a suspensão pode ser imediata.

Além dessa representação, este método apresenta dois outros agravantes: é um medicamento caro, e de distribuição irregular pelos serviços de saúde. Estes aspectos afastam a mulher, desta opção, pela falta de recursos, caso seja necessária a compra.

\section{Irregularidade na Distribuição dos Métodos}

A grande maioria da população de baixa renda não dispõe de poder aquisitivo para a compra de métodos anticoncepcionais. O ideal seria que todos os 
métodos fossem fornecidos gratuita e regularmente, pelos serviços de saúde, para que houvesse plena liberdade de escolha.

O que se observa, entretanto, é que, a irregularidade de distribuição de métodos pelos serviços de saúde é uma realidade, levando as mulheres a abandonálos por não dispor de dinheiro para comprá-los.

A irregularidade da distribuição de métodos nos serviços públicos como fator de abandono do método foi também abordado por SUDBRACK (1994) e CARVALHO (2001).

Outro aspecto, digno de nota, é a falta de um leque mais abrangente de tipo de contraceptivos orais nos serviços de saúde. No caso de mulheres que apresentam efeitos colaterais com um determinado produto, elas encontram dificuldade de optar por outro na rede pública, levando-a a aquisição nas farmácias, na tentativa de adequação ao método.

Em Feira de Santana, durante um determinado período, houve a centralização de distribuição de métodos anticoncepcionais. Aquelas mulheres que moravam mais distantes, o valor gasto com transporte, para chegar ao local da distribuição, era, às vezes, mais alto do que o valor de anticoncepcionais mais baratos na farmácia. Mesmo as mulheres que tenham, eventualmente, dinheiro para comprar a cartela de pílulas, acabam tendo acesso só às marcas mais baratas. São essas que possuem uma alta dosagem de hormônios, trazendo, com isso, efeitos colaterais mais sérios; o que leva, portanto, as mulheres abandonam mais rapidamente o uso do método (SUDBRACK 1994).

Duas entrevistadas fazem referência a esta situação.

"Ao planejamento familiar eu fui quando usava anticoncepcional: eu fazia no posto de saúde, eu pegava o comprimido, e quando não tinha, eles davam um, pra substituir o microvilar. Foi quando eu comecei a sentir mal foi aí, por que começou a variar, e dizer que faz mesmo efeito, não se dava bem de jeito nenhum, aí eu que não tinha condições de comprar..." (12.10) 
"Eu sempre falava para ela olhe Dr". está me prejudicando muito pra todo dia tá tomando anticoncepcional. Ela disse pra eu pensar o que eu ia fazer: se eu queria ligar ou se eu queria ou se eu ia botar o DIU, ou se eu ia tomar a pílula; por que antes disso eu cheguei a tomar a injeção a "Deprovera", ... mas sempre faltava, a coisa mais difícil era ter ela ai no Posto." (19.6)

Os trâmites burocráticos dos serviços, e o descaso na aquisição de métodos contraceptivos são entraves, que devem ser analisados pelos gestores de saúde, para que não haja interrupção na sua distribuição, quando propõem atendimento à saúde da mulher, principalmente na área contraceptiva. Às vezes o atraso no atendimento por, apenas, alguns dias, implica no aparecimento de gravidez indesejada ou abortos provocados.

\subsection{Satisfação com a Prole}

Há muito tempo que a cultura da família numerosa deixou de existir no Brasil. ANDRADE (1997) lembra que nas famílias abastadas, o número de filhos garantia o poder político e econômico, cada um ocupava uma posição chave. Nas famílias pobres a meninada era uma riqueza, tinha com certo que contribuiria com o sustento da casa o mais cedo possível.

A mudança no nível de fecundidade no Brasil iniciou-se entre as décadas de 60 e 70, influenciada por vários fatores, entre eles, a crescente urbanização, e a criação do parque industrial. MARTINS (1999), cita Camarano que acredita que o desenvolvimento de uma sociedade urbana - industrial traria melhoramentos no padrão de vida e a veiculação do valor da família pequena.

A entrada da mulher no mercado de trabalho não deixa de influenciar no tamanho da família, pela dificuldade de se manter a família numerosa.

Analisando a taxa de fecundidade total (TFT) no Brasil, MARTINS (1999) cita (Campanario e Yazaki; Carvalho e Wong e Monteiro e cols) que também estudaram o assunto e afirma que, em 1960, a TFT era de 6,0 filhos por mulher com idade fértil. Depois de 25 anos a TFT alcançava 3,5 filhos por mulher, em idade 
fértil, e, em 1996, estimava-se uma taxa de 2,3 filhos por mulher. Consideram, ainda, que o declínio da taxa de fecundidade está relacionado ao rápido processo de urbanização, e à importância das cidades e da comunicação em massa (Rádio, TV), para difusão e assimilação de valores e novas idéias.

Não podemos esquecer que, as técnicas de contracepção modernas, que tiveram o seu auge na década de sessenta, levaram a mulher a exercer algum controle sobre a sua fecundidade e planejar a sua família.

\section{Número de Filhos}

Uma das justificativas das mulheres entrevistadas para realizar a esterilização diz respeito ao número de filhos desejados. A esterilização seria, portanto, o método de escolha pela segurança de que assim elas não teriam mais filhos:

\footnotetext{
"[...] Ai quando aconteceu eu deixei e pensei: quando eu ter o segundo eu ligo." (1.3)
}

“[...] Ai pensei: do terceiro eu ligo, não quero nenhum filho a mais.” (1.5)

"Eu sempre pensava comigo, depois que - eu ter três filhos eu ligo." (1.6)

“Eu queria ligar por que eu só queria três filhos.” (1.7)

"Ai eu resolvi que devia ligar: eu já tenho dois filhos, crio um menino $e$ aí eu falei três está bom demais." (2.8)

Para algumas mulheres ter ultrapassado a prole, que idealizava, é uma situação, às vezes, vivida com resignação. As duas primeiras falas são da mesma entrevistada; entretanto, o fato de ter ultrapassado o número idealizado de filhos não 
a impulsiona para a busca de um método reversível mais efetivo. Ela vai aguardando o dia em que possa realizar o sonho de encerrar definitivamente sua vida reprodutiva.

Na tentativa de se livrarem dos grilhões impostos pela pílula, e com um leque muito restrito de opções, o que almejam mesmo, é encontrar uma solução definitiva quando atingem o número de filhos que consideram ideal.

"Eu comecei minha vida sexual eu tinha 14 anos, minha filha tem 17 anos, quando ela nasceu eu comecei a tomar comprimido, eu evitei 03 anos; aí veio a $2^{a}$ que tem 14 anos. Passei mais três anos evitando. Aí veio a de 11 anos. Evitei mais quatro anos e meio. $O$ menino que tem 06 anos veio e continuei com a pílula. Aí depois de 06 anos, e continuei a pílula, ai depois de 06 anos veio esse :nasceu está com 04 meses. Aí eu resolvi ligar por que já estava com 05 filhos." (11.1)

"A ligadura, eu decidi porque sei não ficar só parindo, parindo. Aí disseram que aqui no hospital da mulher ligava, que o doutor ligava." (14.5)

"Por que eu tenho já quatro filhos e já estava demais, né?" (15.5)

"O que me levou a ligar, mesmo, foi a quantidade de filhos" (15.10)

"Foi pelo número de filho, que a situação está difícil e a educação em primeiro lugar, e a vida hoje tá que tá, a gente tenta educar..." (16.8)

"Porque muito filho e as condições, né?" (17.3)

“Eu fiz, porque já tinha filhos demais. O remédio pesou também, mas foi mais o número de filhos..." (19.9)

A satisfação com o número de filhos, expressada pelas mulheres entrevistadas, e a necessidade de limitar o número desses, está, geralmente associada 
às necessidades materiais e ao desejo de oferecer melhor qualidade de vida aos seus filhos, e a sua família.

\section{Condições Sócio-econômicas}

Quando informam da necessidade da limitação de número de filhos, o argumento que mais aparece é a falta de recursos financeiros. Ao lado disso, alegam algumas questões sociais que as impedem de ter número maior de filhos. Das mulheres entrevistadas o número de filhos variou de 1 a 12 , com o predomínio de 2 a 3 filhos.

"O meu marido gostou de eu ter feito porque ele é luma pessoa casada e tem mais três filhos." (1.14)

"Eu fiquei muito preocupada para tomar a vacina. Na época meu marido estava praticamente desempregado, e ell criei medo de acontecer a mesma coisa com este. Quando eu tivesse esse de tomar vacina que custa um salário minimo ou mais, na época o salário era 131,00 e a injeção 143,00: mais de um salário né?" (2.7)(fazendo referência a $R h$ negativo)

"Decidi por causa de minhas condições financeiras. Meu marido bebe, eu não tinha condições nenhuma de ter, eu já estava desempregada."(4.5)

A necessidade de trabalhar fora, ou colaborar com o sustento da casa, também é referido como motivo para limitar o número de filhos.

“... porque as coisas estão tão difíceis não é brincadeira prá gente pagar escola do jeito que as coisas estão e também hoje em dia com muitos filhos você não pode trabalhar." (3.12) 
“E tudo isso, a vida está tão difícil, prá três filhos. Quando eu engravidei dela eu parei de trabalhar por que eu trabalhava autônoma vendendo cosméticos." (6.6)

“[...] porque quando entrei logo para o PACS, disseram: Ah! Se engravidar você perde o emprego. Ai eu fiquei com medo, porque era recente e o que eu mais queria era esse trabalho." (12.5)

“Minha preocupação era não perder o emprego. Aí eu peguei logo e liguei. Eu tinha medo de perder emprego. Eu queria muito esse trabalho porque eu lutei tanto para ter ele e perder assim através de um filho, eu peguei e liguei." (12.7)

"Ah, porque eu trabalho... minha mãe já fica com a menina. Aí, com mais esse agora, é muito trabalho pra ela. Aí eu disse: é melhor eu ligar porque não tem condições de estar pagando ninguém pra tomar conta." (18.3)

Algumas mulheres argumentam que o menor número de filhos oferece melhor condição de educá-los e proporcionar uma melhor escolarização. As dificuldades que enfrentam "no mundo de hoje", também respondem como impossibilidade de suprir as necessidades básicas dos seus filhos:

"Porque não queria mais filho, sei lá por causa das condições também, não é? Com muito filho não dá, também as condições hoje são muito precária... Eu não queria mais filho mesmo, o sofrimento é muito grande."(7.3)

"Ah eu pensei que eu tinha muitos filhos e eu não tinha condições de criar mais de cinco e já estava na idade avançada prá eu ainda ter mais filhos. Eu tenho três filhos indesejados, eu não planejei." (10.6) 
“[...] Pensei que já tinha 05 filhos e não valia mais a pena engravidar. E hoje em dia está tão difícil da conta de 05 filhos pra dar estudo, pra dar de tudo. Pensei: acho que não estou pecando não por que eu vou ligar não." (11.6)

"Como eu já tinha 3 filhos eu achei que eu poderia fazer, por que prá que mais de três filhos no mundo de hoje né?... eu não tenho situação tão equilibrada assim, eu faço da vida gato e sapato prá conseguir." (13.5)

"[...] porque já tem dois com ele (marido) e mais dois só dele, inteirava quatro, e as condições de vida, a educação do filho é coisa muito difícil pra poder criar os filhos, então foi desse jeito que eu arrumei um jeito de ligar logo, pagar prá poder ligar." (16.3)

As questões sócio-econômicas e financeiras, principalmente na população de baixa renda, traduzem-se como impedimento para que algumas mulheres, tenha maior número de filhos.

Este aspecto também foi encontrado por OSSIS (2001), na altura em que registra que, de modo geral, mulheres laqueadas disseram que sua decisão de parar de ter filhos começou a ser tomada em função das condições financeiras da família.

A percepção de CARVALHO (2001), ao analisar a fala de suas entrevistadas, é que o poder aquisitivo, muito baixo, da maioria da população, poderia ser apontado como um dos pontos importantes na discussão sobre a queda da fecundidade no Brasil.

MARCOLINO (1994), também faz referência a condição sócioeconômica e ao número de filhos, como sendo aspectos que emergiram com bastante ênfase nos depoimentos por ela coletados.

A representação que a mulheres entrevistadas demonstram a respeito do menor número de filhos, e que circula em sua comunidade e é veiculada pela mídia, como pelos profissionais de saúde, é que cada casal deve ter o número de filhos que possa criar e educar com dignidade. 
Assim, a satisfação com a prole, de alguma forma, está estreitamente relacionada às condições sociais, econômicas e financeiras, em que vivem as mulheres entrevistadas.

Fazendo contraponto a essas idéias MINELLA (1998) analisando a fala de uma de suas entrevistadas que defende a esterilização em mulheres pobres como forma de diminuir a miséria, afirma que a diminuição da prole, por si só, não representa uma garantia de melhora no padrão de vida. E que a renúncia radical à maternidade, observável nos setores populares, estrutura-se de modo que não se lute para ter mais. Em lugar disto, a meta se desloca no sentido de assegurar que o pouco que se tem seja suficiente para alimentar poucos, transformando-se, nestes casos, a esterilização num poderoso instrumento de acomodação.

\subsection{Informação sobre a Contracepção}

O PAISM tem, em sua formulação teórica, o marco de sua força, representando um modelo de política pública de saúde que, deve ser adequadamente estabelecido, segundo o processo de descentralização, regionalismo e hierarquização do SUS (FORMIGA FILHO 1999).

Dentre as ações do PAISM, de assistência integral a saúde da mulher, encontra-se a atenção à saúde reprodutiva. Entretanto, a atenção integral e o conceito de saúde reprodutiva, ainda se encontram no campo teórico e têm sido efetivado em poucos serviços.

Como um dos componentes fundamentais do atendimento integral à saúde da mulher, o planejamento familiar é considerado, pelo PAISM, como parte indispensável e importante, assim como são o pré-natal, a prevenção do câncer ginecológico, e a prevenção das doenças sexualmente transmissíveis (DST).

O que se observa, na prática, é que os serviços dão prioridade à atenção materno-infantil, mantendo o planejamento familiar em segundo plano.

Dentre as ações básicas do planejamento familiar, estão o aconselhamento e informação. Estes deverão ser prestados ao casal que deseja regular a sua fecundidade, e, assim, propiciar a livre escolha de métodos. Estes 
esclarecimentos que deverão ser fornecidos, regularmente, ao maior número de pessoas possível.

A filosofia básica, do programa de planejamento familiar, é oferecer educação, informação, aconselhamento e orientação à mulher ou ao casal para que possa haver uma escolha consciente do método que deseja usar.

Na visão de DIAZ e DIAZ (1999), a grande maioria dos serviços indica ou prescreve os métodos de acordo com a preferência dos provedores, ou da disponibilidade dos mesmos. Existe, entre os médicos, a tendência de considerar que a população está muito mal informada e não tem capacidade para entender os métodos, razão pela qual eles devem escolher pelas usuárias.

$\mathrm{O}$ acesso das mulheres a diferentes métodos é restrito. Em muitos serviços não são oferecidos todos os métodos. Os de percepção da fertilidade ou de barreira, quase não são trabalhados. Talvez por isso é que se verifica que o uso da pílula e da laqueadura tubária, como método contraceptivo, é quase exclusivo entre as mulheres.

\section{Falta de Acesso ao Planejamento Familiar}

Acessibilidade pode ser entendida, no âmbito da saúde pública, como a relação existente entre as necessidades da população, em termos de ação de saúde, e a oferta de recursos para satisfazê-la. Os obstáculos ao acesso se traduzem na combinação de fatores de ordem geográfica, organizacional, sócio-cultural e econômico. Compete, portanto, aos gestores de saúde a eliminação desses obstáculos que se interpõem entre a população e os recursos de saúde.

A maioria das entrevistadas faz referência a nunca ter freqüentado o serviço de planejamento familiar:

"Eu já tinha conversado com o médico para ele fazer e depois que tive o neném fui lá ele marcou prá fazer... não passei no planejamento do hospital." (1.13) 
"Nunca freqüentei o Serviço de planejamento familiar. Às vezes o médico passava as pílulas e as vezes eu comprava na farmácia." (2.5)

"Eu fui no médico e ele passou, mas nunca freqüentei o planejamento familiar não." (6.3)

"Nunca fui ao planejamento. Conhecia outros métodos mas confiava mais no comprimido por que nunca senti nada." (11.7)

"Nunca fui ao planejamento familiar." (14.3)

"Nunca fui ao planejamento familiar" (17.2)

"Eu nunca evitei filhos, nunca tomei remédio pra evitar, e nunca fiz nada. Desde o primeiro marido, o meu primeiro filho está com 12 anos, nunca fiz nada o outro filho está com 05 anos e este que nasceu agora." (20.1)

"Nunca fui ao Posto de Saúde. Fui fazer um pré-natal do menino de 05 anos. Desse eu fiz no hospital." (20.2)

As falas das entrevistadas deixam claro que as ligaduras tubárias são realizadas em mulheres que não freqüentaram serviços de planejamento familiar. Mesmo aqueles que dizem "conhecer," todos os métodos, afirmam que as informações recebidas, aparentemente, não foram recebidas de profissionais da equipe de planejamento familiar. Tudo leva a crer que as ligaduras tubárias são combinadas durante o pré-natal ou, mesmo, no momento anterior ao parto.

A acessibilidade organizacional, também é abordada pelas mulheres. Isso se dá quando falam da falta de tempo em freqüentar o planejamento familiar. Para mulher que trabalha, os horários de atendimento dos serviços de saúde não permitem que ela participe de reuniões educativas, nem mesmo da consulta, pois, na maioria das vezes o tempo dispensado para esse fim, traduz-se na perda de um período de 
trabalho. Para outras, os afazeres domésticos também se tornam um dificultador, no que tange à frequiência ao planejamento familiar. Os depoimentos que se seguem mostram esta realidade:

"Só fui duas vezes no planejamento familiar, e não fui mais. Também não tinha tempo: eu trabalhava."(3.5)

"Teve uma época que eu freqüentei o planejamento, no posto, mas como tinha menino pequeno era difícil de ir, eu passei a comprar o remédio." (10.2).

No estudo de MERRIGHI e cols.(1997), das 31 mulheres que não compareceram para as atividades agendadas(no total de 54 mulheres), as justificativas citadas, para o não comparecimento foram: problemas de saúde com o filho, esquecimento ou equívoco quanto à data marcada,dificuldade de acesso à instituição por residir em local distante, ou por dificuldade com meio de transporte.

Mesmo entre aquelas entrevistadas que disseram ter freqüentado o planejamento, algumas para lá se dirigiram desejando colocar o DIU. Como antes dito, este método que depende, exclusivamente, do profissional de saúde para sua utilização. Talvez este se constitua em um dos motivos mais significativo para que frequientem o programa de planejamento familiar. Outras, no entanto, buscavam obter a ligadura de trompas. Estes fatos não apontam a frequiência como sendo uma forma de obter aconselhamento ou informação, mas para atingir objetivos específicos.

"Há muito tempo atrás, eu fui ao planejamento familiar. Uma vez, no posto, assisti uma palestra: era para colocar o DIU, mas eu desisti e não voltei mais." (3.5)

"Teve uma época que eu freqüentei o planejamento, no posto, mas como tinha menino pequeno era difícil de ir eu passei a comprar o remédio" (9.6) 
"Fui ao Planejamento Familiar uma vez no posto. Lá onde eu trabalhava também tinha sempre palestra. Aí eu achava melhor ligar porque não queria filho mesmo. Eu conhecia todos os métodos, da camisinha, injeção, DIU, isso tudo. Mas eu achava melhor pra mim o remédio." (18.2)

“No Hospital da Mulher fui a algumas palestras, sei dos métodos mas só queria ligar." (19.3)

Na visão de HOGA (1996), a falta de motivação das mulheres, para ir em busca de assistência anticonceptiva, associa-se a muitos fatores. Um deles está associado à atitude defensiva, de que as mulheres tomam, ante a possibilidade de invasão de sua vida privada, querendo manter reservada sua condição de existência.

Outros aspectos levantados pela autora, a partir da fala de suas entrevistadas são: receio de ser discriminada pela sua condição sócio-econômica, considerar que buscar serviço de saúde sem estar doente é "coisa prá rico"; vergonha de se expor fisicamente a profissionais de saúde; dificuldade de acesso; frustração com o tipo de assistência recebida; dificuldade de comparecer às reuniões e, também, dificuldade de exporem seus problemas pessoais nas sessões de grupo. Alie-se a isso o fato de as entrevistas individuais ser consideradas muito rápidas não dando tempo para expor seus problemas de forma satisfatória.

A falta de motivação, para freqüentar o planejamento familiar a partir de todos aos aspectos levantados per HOGA (1996), pode ser estendida a nossa realidade, vez que as condições de atendimento, e as demais questões, levantadas pelas mulheres nos presentes depoimentos, em nada diferem das encontradas por esta autora.

\section{Informações Equivocadas}

A desinformação, a respeito da necessidade premente da ligadura tubária, referida pelas entrevistadas, remete a equívocos importantes. Como fonte dessas informações foram citados os profissionais de saúde. Talvez a distância estabelecida 
entre profissionais de saúde e cliente não permitam que o entendimento seja possível entre eles.

É comum que as usuárias recebam enorme quantidade de informações, às vezes, até, detalhadas, sobre coisas que não precisam ou desejam saber, e não têm oportunidade de perguntar aspectos que são realmente importantes para elas. Além disso, são poucos os profissionais que investigam e desconstroem os mitos, crenças e informações equivocadas (DIAZ e DIAZ 1999).

As representações a respeito da necessidade de ligadura tubária como único caminho para regulação da fecundidade, podem ser originadas da informação recebida pelos profissionais de saúde. Mas não devidamente decodificada pelas mulheres devido ao vocabulário utilizado na interação profissional de saúde e cliente:

"Eu tomava anticoncepcional, e ai eu parei para engravidar. Engravidei duas vezes e perdi por causa do meu tipo de sangue que é negativo, eu não sabia..." (2.1)

"[...] Resolvi ligar foi justamente por causa do sangue. Cada vez que eu tivesse um filho tem que tomar a vacina, né?" (2.4)

"Conversei com a enfermeira que fazia o meu pré natal, ela achou que, justamente, por causa do meu tipo de sangue, a melhor maneira de evitar era ligando." (2.9)

“... No ano passado eu tive uma dor... Era que os comprimidos acumularam na trompa. Então foi preciso tirar... Tiraram a trompa esquerda e o ovário esquerdo... No início, na ultra, suspeitaram de gravidez nas trompas, mas quando o médico abriu e tirou não foi filho não. Agora como eles ficaram lá dentro eu não sei." (4.4)

"A ligadura eu decidi por que desde que eu tive a primeira menina, a médica disse que eu não tinha condições, de ter parto normal porque 
tinha o colo muito fechado... Aí também eu tenho sangue negativo..." (6.4)

"Por que o médico do pré-natal disse que eu já devia ter ligado, que eu não podia ficar engravidando não por causa dos meus problemas... Que é melhor ligar do que fica parindo todo ano..Fez cesária e ligou."(9.3)

"[...] o médico veio e aí falou que eu não podia mais ter filho, e me explicou que eu tinha tido eclâmpsia e se eu tentasse engravidar de novo, se não perdesse o bebê no começo da gravidez, eu não chegaria aos 7. E, se chegasse eu teria crises e quando o bebê nascesse ia nascer com problema. Aquilo deu muito medo." (11.4)

"[...] eu fiquei com medo do bebê morrer e ficar sempre com aquele sonho. E se eu ficasse como eu estava, tinha chance de fazer um tratamento e ter outro filho; aí sim: eu poderia ligar e assim fiz..." (11.5)

\section{Acesso à Esterilização}

Embora, atualmente, as mulheres estejam evitando filhos, da maneira como podem, ficam aguardando o dia em que possam realizar o desejo de encontrar a solução definitiva na regulação de sua fecundidade: a ligadura tubária (HOGA 1996).

Dentre os fatores que dificultam, para a mulher, a realização da ligadura de trompas, está o acesso aos serviços de planejamento familiar que, quando existem, não têm disponível a cirurgia de esterilização feminina gratuitamente.

As mulheres às vezes se deparam com barreiras burocráticas existentes nas instituições de saúde, que estabelecem, na sua visão, algumas dificuldades.

"Desde a $2^{a}$ filha eu pensei em ligar, mas sempre que eu procurava o posto de saúde, tinha aquela dificuldade... Não podia ligar, por que ainda estava cedo e sempre aquela dificuldade... então falei com o 
médico: "ô Dr. Eu preciso eu já tenho a quarta filha e eu preciso ligar" e ai eu conversei com uma amiga que trabalha no hospital que eu liguei, e ai ela ajeitou lá, e eu fui na palestra duas vezes lá, e o termo de responsabilidade meu marido assinou"(3.6)

"Só que ai era muita dificuldade prá ligar não sei se ainda está. Quando eu estava grávida e ia lá no médico e falava prá ligar. E eles sempre botava dificuldade. E eu falava que já tinha muitos filhos que não tinha condições aí eles me tapeavam muito"(19.7)

Às vezes a barreira é econômica, mesmo em serviços que atendem pelo SUS. A remuneração, cobrada para o procedimento, umas vezes facilita, outras dificulta $\mathrm{o}$ acesso das mulheres à ligadura:

"Aí fiz cesárea pelo SUS, e paguei prá ligar." (16.9)

"Acertei tudo na hora... Eu pedi ao médico até pelo amor de Deus prá me ligar. Aí ele disse: seu marido já acertou tudo comigo." (16.10)

"Durante o pré-natal, eu vinha mas não tinha coragem de pedir a ele, porque o povo dizia que era pago e eu tinha medo." (20.6)

Em alguns casos a realização da cesárea é a via de acesso para a realização da ligadura tubária. Estes também foram os achados de (VIEIRA 1998; MINELLA 1998; OSSIS e cols 1999; PIROTTA \& SCHOR 1999; OLIVEIRA 2000).E é o que se registra neste depoimento:

"Aí a menina veio aqui comigo marcou, eu assinei. E aí vim me internar, aí fizeram a cesárea e ligaram. "(14.6)

Existe, ainda, um aspecto levantado por CECATTI (1999), que é importante ser investigado: segundo o autor existem indícios, corroborados pela 
observação clínica de muitos profissionais, de um contigente de mulheres que, não desejando mais gravidezes e acreditando ser a esterilização cirúrgica a única opção viável para solução definitiva de seus problemas, decidem engravidar única e exclusivamente com o propósito de, ao fim da gravidez realizar laqueadura tubária.

Um outro aspecto, muito freqüente na nossa realidade, é o patrocínio de candidatos a cargos eletivos, que oferecem a ligadura de trompas em troca de votos.

ANDRADE (1997), faz referência à intervenção de políticos na realização de ligadura de trompas. Como exemplo cita a instalação de uma CPI, no ano de 1991 em Recife, para investigar o assunto. Segundo a autora uma exvereadora e um ex-deputado, notoriamente conhecidos pela prática de troca de votos pela ligadura, confirmaram, perante aos membros da CPI, a sua "boa intenção", no intuito de ajudar mulheres carentes. Houve denúncia de mulheres esterilizadas aos 15 anos de idade.

Em Feira de Santana é de domínio público a prática de troca de votos por esterilização. Tentando diminuir a visibilidade do fato, os candidatos, transferem sua ação para cidades vizinhas, e mantêm um sistema de transporte gratuito, para o deslocamento das clientes usuárias dos serviços. As informações foram confirmadas pelas próprias entrevistadas.

“[...] Agora se fosse pra fazer com os políticos eu não fazia não, é tudo nas carreiras..."(1.15)

"[...] aí falei: vou ligar. Aí o pessoal veio, e falou: se você quiser ir, você vai ligar, ai eu encaminhei os exames e fiz a ligadura. Fui, viajei e me liguei lá em São Gonçalo." (12.6)

"Aí ele [o marido] chegou e pegou meus exames e fez essa surpresa pra mim, e eu fui fazer lá em São Gonçalo."(19.8)

"Olha, eu fui fazer em São Gonçalo, a besta leva 16 pessoas, ...Faz todos os dias. Entrava de duas em duas. O quarto fica com oito camas, é muita gente." (19.16) 
VIEIRA (1994), também faz referência a este assunto quando diz que vários "setores" da sociedade têm estimulado o uso da esterilização feminina. Entre estes estão os políticos em campanhas eleitorais que oferecem esterilização gratuita em troca de votos e apoio popular.

Ainda, foram encontradas várias bibliografias que fazem referências a esta questão (Assembléia Legislativa do Estado do Rio de Janeiro, 1991; HARDY e cols, 1992; Assembléia Legislativa do Estado de Goiás, 1992; ANDRADE 1997; ANONYMUS 2002).

\section{Segurança na Esterilização}

A representação que as mulheres possuem a respeito de método anticoncepcional, cem por cento seguro, é a ligadura de trompas. Às vezes essa representação é reforçada pelos próprios profissionais de saúde.

Para COSTA e cols. (1995), a idéia é a de que: se não se deseja mais filhos, não há motivo para continuar se preocupando em evitá-los, quando é possível resolver o problema definitivamente. A capacidade reprodutiva aparece como um problema, um estorvo ou uma ameaça. A laqueadura aparece, então, como uma solução:

“[...] voltei a usar a camisinha novamente, e aí disse: "olha é melhor eu ligar porque, pelo menos eu ligo e fico livre, e não fica essa preocupação de tomei não tomei, e ai resolvi ligar". (3.3)

“[...] e, também pelo medo. Eu já estava com esse problema e não sabia se eu ia continuar tomando remédio... Aí, conversei com o meu médico e resolvi ligar por causa disso." (4.6)

"[...] não ia esperar para ter mais filho não. E ficar tomando comprimido, eu não ia querer mais nem botar DIU: queria ligar mesmo." (5.4) 
"Mesmo tendo usado pílula 11 anos, eu queria ter certeza que não ia engravidar mesmo. Só ligada que eu tinha certeza." (7.5)

"A ligadura eu acho mais seguro."(14.10)

"Só queria ligar, porque dois filhos pra gente educar é mais fácil... O único método que me dava certeza que eu não ia ter mais filho era ligar." (18.4)

"E quis ligar porque ligar é mais seguro." (20.4)

No estudo de PIROTTA e SCHOR (1999), foi encontrado pela autora que $10,7 \%$ das mulheres referem optar pelo método definitivo, em virtude da segurança que oferece.

Segundo MARCOLINO (1994), as mulheres compreendem a esterilização como um meio mais seguro e mais eficaz para limitar o número de filhos. A cirurgia passa ser vista como uma solução para vários problemas, na expectativa mais íntima das mulheres. A esterilização cirúrgica tem o sentido de ser recurso definitivo, eliminando a insegurança de uma gestação indesejada e a não mais necessidade de se preocupar com a contracepção no seu dia-a-dia.

Há, ainda, o caso de mulheres que, mesmo não estando seguras da decisão, incorporam a indicação médica no seu discurso:

“[...] Desde que eu tive o menino [2] que eu já ia ligar... Também na época eu estava muito nova, agora eu acho que ainda estou nova, prá ligar, mas a médica optou, porque não tenho mais condições de ter mais outro, e prá não correr o risco, ela achou melhor ligar." (6.7)

Outras tomam a decisão a partir da informação, durante o pré-natal, de que serão submetidas a uma cesárea. O que aparece como o momento de aproveitar a oportunidade para realizar a esterilização: 
"No início do pré-natal, eu nem pensava que ia ligar. Só no final, mesmo quando fiquei certa que ia fazer cesárea, foi que ficou definido, é que eu decidi. Eu vou ligar por que também acaba essa história de controle, que eu não posso tomar comprimido..." (13.11)

O estudo de VIEIRA (1998), demonstra que grande parte das mulheres (70\%) concorda que o único método confiável é a esterilização.Consideram, ainda, que a melhor maneira de obtê-lo é através de cesariana (82\%).

A esterilização, realizada durante a cesariana, é uma tendência nacional. Esta premissa ficou confirmada em diversos outros estudos a exemplo de (OSSIS et al 1990; HARDY e cols 1993 BURSZTYN 1997; MINELLA 1998; CECATTI e cols 1999).

Algumas mulheres, mesmo sem experiência prévia com outros métodos contraceptivos, manifestam a representação de que depositam confiança na segurança da esterilização. E isso está, de tal maneira, internalizado, que rejeitam, sem querer discutir, outros métodos.

"Aí eu falei: o certo vai ser ligar mesmo. Nunca usei remédio, mas achei que podia falhar; e ligar é mais seguro." (17.5)

"O meu marido falou: se você não operar, vai botar o DIU ou pegar remédio no Posto mas eu sempre preferi ligar... Eu sempre disse: a tomar remédio eu prefiro ligar." (20.8)

A desinformação das mulheres a respeito dos métodos contraceptivos reversíveis. As barreiras encontradas para o acesso ao planejamento familiar, o atendimento deficiente dos serviços de saúde, incapazes de atender à demanda das mulheres por saúde reprodutiva. A representação que as mulheres têm a respeito da segurança dos métodos, os mitos, crenças e informações equivocadas, aliados ao desejo de encerrar a fecundidade são ingredientes que empurram a mulher para a ligadura de trompas, como a solução de seus problemas para regular a fecundidade. 


\subsection{Informação sobre Esterilização}

A informação é um dos principais recursos utilizados para o aconselhamento quando a respeito da laqueadura tubária. Uma das principais finalidades, da informação, é facilitar o entendimento do processo.Esta deve ser sempre completa, exata, e imparcial objetivando o entendimento da mulher sobre o procedimento que deseja realizar.

As palestras educativas, ou a orientação individual, sobre métodos contraceptivos ou planejamento familiar, devem sempre levar em conta que a sua finalidade principal é ajudar a mulher a tomar uma decisão, livre e esclarecida, a respeito do método contraceptivo que deseja utilizar.

Para MARCOLINO (2000), esclarecer a mulher, quanto a assumir os riscos e consequência da cirurgia esterilizadora, depois que ela já está informada e orientada, parece ser a palavra de ordem no trabalho da equipe envolvida com a esterilização cirúrgica. $\mathrm{O}$ aconselhamento é a atividade que garante um suporte para a tomada de decisão desta mulher.

\section{Falta de Informação sobre Esterilização}

A ligadura tubária é um método legítimo de contracepção. É o segundo método de escolha entre as mulheres. Por ser um método definitivo, que pode levar a complicações à saúde da mulher e ao arrependimento tardio, a sua escolha deveria se dar após informações e conhecimento de todos esses aspectos que envolvem o procedimento. Afinal, não se trata de apenas uma cirurgia simples, mas de uma intervenção cirúrgica que inclui uma série de considerações sobre a mulher, as quais vão interferir no seu contexto de vida social, sexual, e fisiológica.

A falta de informação, sobre a esterilização está presente em várias falas das entrevistadas, e em alguns casos, a responsabilidade fica totalmente com a mulher: 
"Aí o médico disse: é uma decisão sua e aí programou para fazer o parto"(2.11)

"Não, a única coisa que eles me perguntaram é se eu tinha consciência do que eu estava fazendo, se meu marido concordava, que eu tinha de assinar um termo de responsabilidade, e meu marido também. E só poderia ligar se meu marido assinasse."(3.7)

"Se tinha assim algum perigo, alguma coisa, não foi passado prá mim, as conseqüências, eles não passaram." (3.8)

Em outro momento, a mulher chega a se sentir culpada por não ter acesso a informações suficientes, antes da realização da ligadura.

"Porque também eu nem culpo ninguém lá, eu culpo a mim mesmo, porque eu não fui fazer o planejamento. Só fui a duas palestras a pulso, com certeza eles dizem tudo nas palestras."(3.9)

Mesmo já tendo tomado a decisão, a falta de informação, tanto do procedimento quanto das conseqüências de ligadura, leva a mulher a enfrentar a cirurgia mesmo sentindo medo de tudo que a ela é desconhecido.

"[...] Ai no dia da ligação eu fiquei com medo. Todo mundo diz que dá mioma, que dá problema na cabeça no lugar que liga. Aì, eu fiquei com medo, ai eu falei: não vou ligar, não vou, não vou." (8.2)

"Eu fui com bastante medo, tinha medo de morrer...! Porque o pessoal me metia medo também, que muitas morriam, que a anestesia "raque," se não tomasse cuidado ia ficar paraplégica. Eu ficava com medo, mas, eu fui (risos) mas aí eu fui mesmo!" (12.12) 
"Eu só tinha medo da anestesia eu tinha medo de ficar aleijada. Todos os meus partos foram normais." (15.8)

"Porque o anticoncepcional mesmo só me dava dor de cabeça. Até hoje eu tenho problema de nervoso e acho que causado por ele. Sempre eu trocava de remédio." (19.14)

"Eu tinha muito medo de ligar, porque eu nunca fiz uma cirurgia e tinha muito medo da anestesia. Aí eu ainda marquei com o político em 92, do $2^{\circ}$ menino. Ai quando o carro me pegou aqui prá levar pra São Gonçalo eu fiquei com medo, não fui." (10.5)

"Mas eu tinha muito medo da cirurgia e anestesia. Tinha medo de morrer ou ficar aleijada. Tem horas que fico pensando que nem liguei porque a coragem, eu digo, que foi Deus que me preparou para não ficar nessa preocupação por que já ter cinco filhos e sem condições boas." (10.9)

Alguns relatos chegam a ser chocantes, principalmente na altura em que fica patente o total descaso com a saúde da mulher:

“Não perguntei nada, ninguém falou nada. Aí eu liguei. Não senti nada: só dor de cabeça, porque fiquei muito nervosa. Eu tomei muito soro, porque eu estava de anemia."(8.4)

A representação que perpassa pelo extrato social, de convívio da mulher, é que a única maneira que dispõe para evitar a gravidez, é através da ligadura. Isto fica evidente na fala de algumas mulheres, que tomaram a decisão porque outras mulheres da sua comunidade, assim procederam:

“Não, não tinha orientação de ninguém... Eu via as outras fazendo e não paria e eu também queria parar de parir..." (10.7) 
"Ninguém falou de arrependimento. Todas minhas amigas que já tinha feito me incentivou." (15.7)

"Conversei no hospital. Antes não conversei com ninguém, não fiz prénatal não, só na hora de parir é que decidi. Eu cheguei no hospital aí uma moça falou assim: Por que você não liga, você já tem filho demais, eu falei: não vou ligar não."(17.6)

A necessidade de maior informação, expressada por entrevistadas que, mesmo tendo realizado a ligadura há pouco tempo, falam que gostariam de ter mais informações e, mesmo assim, a decisão foi mantida:

"Mas eu queria que um profissional chegasse pra mim e explicasse como é esse negócio de ligação" (1.12)

"Agora, com relação a ligadura eu acho que devia ter, existir, uma diálogo maior do médico e a paciente porque é uma decisão pra sempre, né? Eu acho que o médico deveria, assim, antes de levar o paciente prá o soro, deveria sentar um pouco, conversar... perguntar..." (13.6)

"Mas, continuo achando que é pouca informação à respeito da ligadura. Mas tem gente que liga com dois filhos e até com um não é? É perigoso, eu que tenho três depois que eu liguei deu, tipo assim, quase um arrependimento." (13.8)

"A maioria das pessoas que conheço, que fizeram ligaduras, eu acho elas muito pouco esclarecidas. São donas de casa, pessoas assim, de mais idade não são pessoas assim que poderiam conversar. Elas só falavam assim: a injeção da coluna dói muito, e depois dói demais, dói demais e nem sequer falam que pode arrepender de querer ter filhos." (13.10) 
A importância do aconselhamento e informação, no caso da laqueadura de trompas, por ser um método definitivo, fica muito mais clara quando analisamos as ambigüidades e contradições, tão presentes em todos os processos humanos. A entrevista individualizada, ocasião em que a mulher pode colocar seus sentimentos e conhecimentos a respeito do método, é de vital importância. Aparentemente as mulheres de nossa realidade, não estão tendo acesso a esse procedimento que, inclusive lhes é de direito.

A Lei $n^{\circ} 9263$ no seu artigo 10,é clara quando determina que "será propiciado à pessoa interessada acesso a serviços de regulação da fecundidade, incluindo aconselhamento por equipe multidisciplinar, visando desencorajar a esterilização precoce." (BRASIL 1998).

O MINISTÉRIO DA SAÚDE (1996), instrui que a atuação dos profissionais de saúde na assistência à anticoncepção envolve, necessariamente, dois tipos de atividades: as educativas e as clínicas, as quais deverão ser desenvolvidas, de forma integrada e promovendo a interação dos membros da equipe de forma a permitir a participação dos agentes da equipe, em ambas as atividades, de acordo com o nível de responsabilidade adquirido.

A importância da equipe multidisciplinar, envolvida na assistência, é evidenciada por MARCOLINO (2000), que ao participar, como observadora, de uma ação educativa conduzida por uma psicóloga, junto à uma mulher que queria submeter-se à cirurgia esterilizadora, verificou que após a atividade educativa esclarecedora, a mulher abandonou a idéia de cirurgia.

ESTEVES e CAMARGO (1991), consideram que a decisão consciente, pela esterilização, é um privilégio de uma minoria abastada da população, que tem acesso a todas as informações e aos meios adequados para realizá-la.

\section{Número de Cesáreas}

A frequiência de cesáreas impulsiona as mulheres a recorrer à esterilização. O desejo de limitar o número de filhos, as experiências das cirurgias, o intervalo interpartal nem sempre observados, e as informações clínicas da 
impossibilidade de repetição de cesáreas, são motivações para a decisão de esterilizar-se.

"Porque com três partos cesariano, né? eu não ia tentar, que é mais perigoso." (5.3)

"Decidi, também por que três cesarianas... depois de três, ninguém tem condições de fazer mais uma cesariana." (6.5)

"Porque não queria parir mais não, os meus partos são meio complicados tudo com anestesia e ai eu resolvi ligar logo. Os três foram cesárea e eu já estava com medo de anestesia." (20.3)

Muitas vezes, no último parto, já é programada a cesárea com antecedência para a realização da esterilização. Neste caso, a mulher aproveita-se da cesárea para fazer uma só cirurgia. Isso, na visão da mulher, se torna bem mais cômodo, por não precisar retornar ao hospital, nem sofrer uma segunda intervenção cirúrgica.

A justificativa para realização de cesárea em gestantes com uma cesárea prévia é antiga. O receio de complicações obstétricas, diretamente relacionado à presença de uma cicatriz uterina, foi durante muito tempo justificativa para a cesárea eletiva em mulheres. A tentativa de conseguir parto vaginal após uma cesárea prévia, parece ser boa alternativa, e é adotada por países desenvolvidos, nas políticas de contenção de cesarianas (CECATTI et al 1999).

\section{Fonte de Informação sobre Esterilização}

As informações, sobre a esterilização, que mais predominam, entre as mulheres entrevistadas, são prestadas por pessoas da sua própria comunidade, familiares, "colegas" e profissionais de saúde. Quando se referem a informações dadas por profissionais de saúde, predomina a figura do médico. Mesmo assim, o que se revela, é que não poderíamos chamar de "informação", são perguntas formuladas, 
pelo cirurgião, momentos antes do procedimento, como uma forma de se certificar se este é, realmente, o desejo da mulher.

"Minhas duas colegas e duas primas e duas irmãs que ligaram não sentem nada, já outras disse que tinha problemas depois que ligo: dor nas pernas, dor na barriga tantas coisas..." (1.11)

"Não, ninguém conversou não, sempre os colegas, né? E o doutor quando foi me ligar falou: "você tem 50\% de pegar cisto no ovário"... “ Cisto no ovário e ter menstruação demais." (12.8)

"As colegas falavam que prá ligar tinha que fazer cesárea, que se não fizesse cesárea eles não ligavam. Tinha que fazer outros exames prá poder ligar. Ninguém mais conversou." (14.7)

"E aí, as "meninas" que iam ligar lá, em São Gonçalo eu sempre perguntava e lá eles faz como? Elas disse: lá ele estrangula mesmo... porque tem uns médicos aí que dá nó. Eu disse: então não quero, eu quero uma coisa bem feita."(19.12)

"Meu marido, que ficava dizendo que conversasse com o médico que se ele me ligasse era uma boa. Não conversei com ninguém. Falei com o médico na hora do parto, que se ele queria me ligar que era uma boa. Antes eu não conversei nada." (20.5)

"Só conversei com o meu marido, com mais ninguém, mas eu já tenho três filhos, trabalho, é muito ruim." (20.7)

PIROTTA e SCHOR (1999), encontraram, em seu estudo, que a maioria das mulheres pesquisadas $(56,4 \%)$, referem que as principais fontes de informações sobre a esterilização, foram "parentes e amigas." Fica demonstrada a participação do grupo doméstico, formado por outras mulheres, na divulgação e consolidação da 
"cultura da esterilização". Notou-se nessas respostas, a ausência de menção às instituições de saúde, o que indicaria a necessidade de aprimoramento dos programas de saúde voltados para a orientação sobre uso de métodos anticoncepcionais e prevenção da gravidez indesejada.

Ao médico e às enfermeiras, referidas como fonte de informações sobre esterilização, as falas foram as seguintes:

"O médico me disse que eu podia me arrepender. E eu disse a ele Jesus não ia deixar eu me arrepender."(2.12)

“[...] durante a gravidez eu conversei muito com minha médica, sobre os problemas que enfrento..." (4.7)

“Tomei a decisão e quis ligar. O médico, que fez meu parto, na hora perguntou quantos filhos eu tinha. Eu disse que tinha três cesarianas $e$ não queria filho mais não. Ele me perguntou se eu não queria esperar o menino, eu disse não... Fez a cesárea prá poder ligar, poderia, até, ser normal, mas eu ia ligar por que é um resguardo só." (5.7)

“.... Ele não falou de arrependimento, só falou se agente queria mesmo ligar, se era aquilo que a gente queria." (12.9)

“Não, eu vim fazer a cesárea e disse que ia fazer a cesárea e ligar também. O médico só me perguntou quantos filhos eu já tinha, que idade eu já tinha, e por que eu queria fazer." (13.7)

"Através do médico. Mas a decisão foi minha mesmo, porque pensei que ia ficar engravidando direto, prá que?" (15.4) 
"Conversei com minha comadre que é"enfermeira" e com o próprio médico... Só que ele marcou quatro vezes e eu fiquei com medo,. Só que depois... tinha medo da anestesia...Eu fiz parto normal e depois liguei pelo umbigo." (15.6)

"Fiz pré-natal com o médico, eu conversei com ele e ele disse: já que você quer ligar vamos." (15.9)

"Quando entrei que o médico foi fazer o toque eu falei assim: eu queria sair daqui ligada. Ele falou assim: "com um mês a senhora volta. E eu disse: eu não quero com um mês não, pode ser que eu não venha. Então, ele disse: quando a senhora sair daqui a senhora já sai ligada. Aí eu liguei. Decidi e fiz." (17.7)

"No Hospital da Mulher fui a algumas palestras. Sei dos métodos mas só queria ligar." (19.3)

Um dos aspectos da opção pela esterilização, que refletem o processo de medicalização social, é o fato de que os procedimentos, e as consequiências da realização da cirurgia são pouco discutidos pelas mulheres e os médicos (SERRUYA, 1996).

Alguns profissionais de saúde têm uma aproximação maior com a mulher, e se preocupam em informar. Este procedimento propicia mais tempo para que a mulher reflita e amadureça a idéia sobre o método:

"Desde que eu tive o menino o médico me falou, aquele doutor... do CEPARH. Ele falou: olha mãe, prá ligar devido ao seu problema de não ter normal, pode ser só que você está muito nova, e se você ligar agora 
corre de, mais tarde, você ter problema de hemorragia, e outras coisas. Então, é melhor você espere mais um pouco para chegar aos 29 ou 30 anos." (6.8)

"A médica me explicou, perguntou se eu queria isso mesmo. Falei que queria." (7.2)

“[...] a médica disse prá eu pensar bem prá não me arrepender, prá conversar com meu marido. Mas ele aceitou tudo e a médica me explicou tudo. Também disse que depois de ligar não tem mais condições de ter filho... toda vez que eu vinha ela falava e perguntava se era isso mesmo que eu queria, que eu só tinha um filho. Acho que ela estava meio assim sem querer fazer." (7.4)

"Conversei lá na firma com a enfermeira... Ela também falou no caso de um dia se eu quisesse mais filho: já sabe que não vai poder ter mais. Mas eu não me arrependo não, eu queria ligar mesmo." (18.5).

O estudo de VIEIRA (1994), demonstra que a maioria das mulheres soube da esterilização através de alguém de suas relações: amigas ou parentes, que fizeram a cirurgia (37.7\%), um terço (32\%), soube através de alguém, como parentes ou amigas, que informou sobre a cirurgia, $20 \%$ foram informadas pelo médico, menos de $3 \%$ souberam através da mídia (imprensa e televisão) e $7 \%$ através de palestras, reuniões ou aulas sobre o assunto.

\section{Sintomas após a Esterilização}

Apesar de termos feito a maioria das entrevistas, com mulheres recém laqueadas, por estabelecermos o intervalo de até seis meses para entrevista.Mesmo assim, encontramos uma entrevistada com referência a sintomas surgidos, após a cirurgia, compatíveis com a sintomatologia mais referida na bibliografia como a 
síndrome pós ligadura (POLLACK 1993; PERDIGÃO 1996; DIAS et al 1998; OSSIS, 2001)

“ Só sinto mesmo que eu não sentia é cólica. Eu não sentia cólica... Hoje quando está perto de vir,03 dias antes é uma cólica... e quando está perto de ir embora é uma cólica, muita cólica mesmo, e a minha menstruação redobrou, corre demais, corre demais mesmo, parece até que é hemorragia" (12.13)

Embora os estudos clínicos apresentem controvérsias a respeito da síndrome pós-laqueadura, a queixa dos distúrbios menstruais é um dado freqüente nos depoimentos fornecidos por mulheres que passaram pela ligadura de trompas.

GEBER e CAETANO (1999), descrevem a síndrome como anormalidades, que ocorrem após a esterilização cirúrgica. Nestas estão incluídas irregularidade menstrual, ciclo menstruais curtos, sangramento menstruais prolongado, aumento do fluxo menstrual, sangramento intermenstrual, oligomenorréia ou dismenorréia.

Para ALBUQUERQUE (1985), estes sintomas que podem ser imediatos ou tardios e levam muitas mulheres a cirurgias, principalmente as histerectomias.

O estudo de ESPÍN (1981), realizado em um hospital da Venezuela demonstra que os motivos de consulta de mulheres, em que se atribuía à síndrome pós laqueadura, é de, 6\%. Diz, ainda, que este percentual vem crescendo paulatinamente. Segundo o autor, as queixas são de mulheres laqueadas pelas técnicas mais usuais como: Madlener, Pomeroy, Irving, Kroener, Uchida, e outras...

FAGUNDES (1993), considera que a aparente ausência dos efeitos colaterais tem tornado esse método bastante atrativo para as mulheres que experimentam efeitos colaterais com outros métodos contraceptivos.Entretanto, este procedimento e também apresenta efeitos colaterais, considerados de significativo risco para a mulher.

DIAS et al (1998), fizeram um esboço tentando explicar os eventos possíveis após a esterilização tubária. 


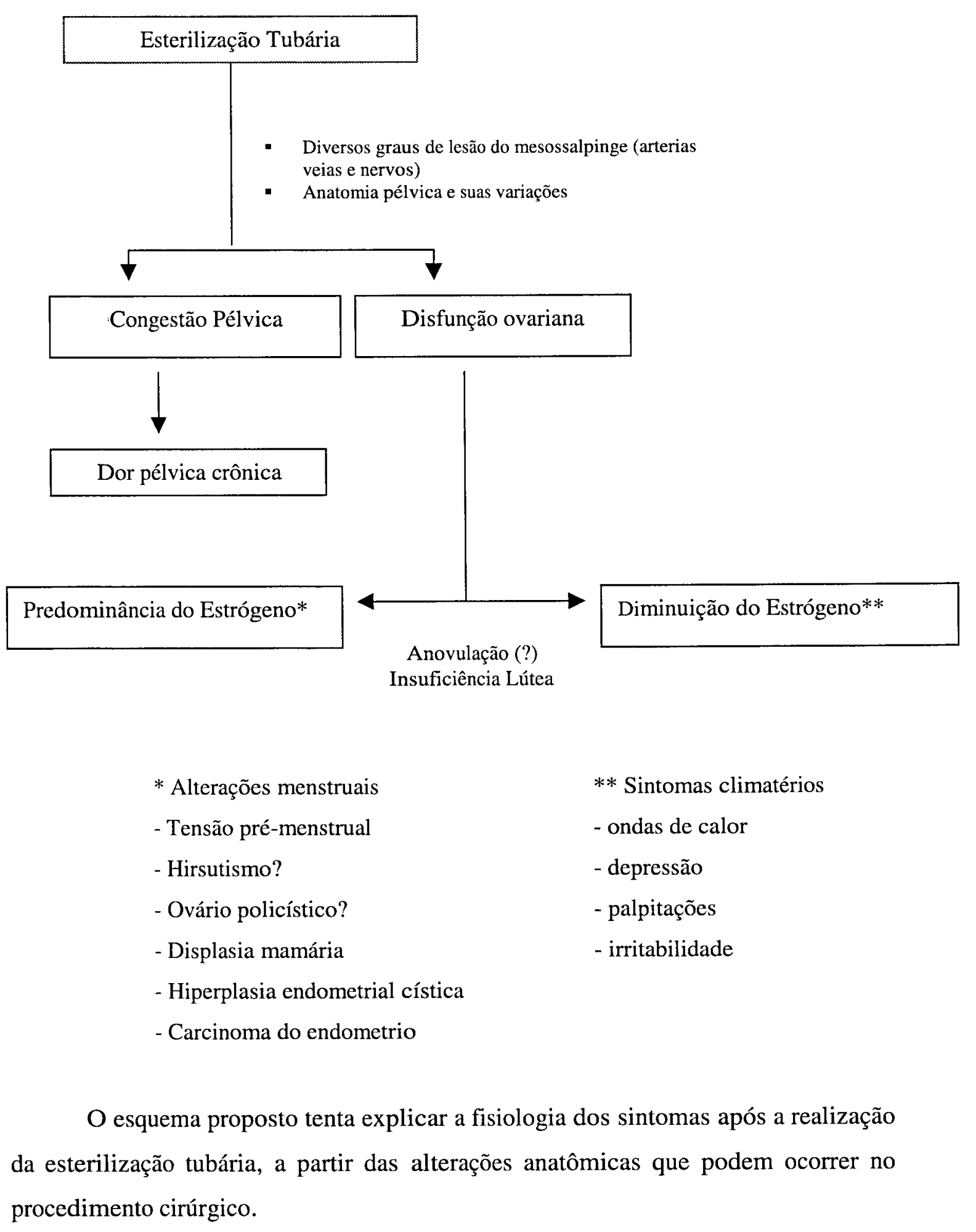




\section{Insegurança com a Técnica da Esterilização}

A falta de comunicação entre a mulher e os profissionais de saúde, gera insegurança quanto à técnica que será utilizada para a realização da laqueadura tubária.

VIEIRA (1994), acredita que, provavelmente, a distância entre médico e paciente não permite que o entendimento seja possível entre eles.

As representações das mulheres a respeito da técnica utilizada, é que algumas são mais seguras do que outras. Esta é a razão pela qual se sentem inseguras quanto à técnica que foi utilizada, no seu caso, porque não recebeu informação à respeito:

"[...]" Eu também achei condição de ligar fora mas eu não queria porque tenho muito medo dessa ligação. E aquele negócio de um monte de gente rápido e de repente todo mundo já ligou e já voltou, e eu ficava pensando: será que essa ligadura é segura?"(3.10)

“Eu não quero mais engravidar. Eu conheço pessoas que... no dia mesmo que eu fui, tinha 2 mulheres lá que eram ligadas e que estavam grávidas." (3.11)

"[...] eu até falei com o médico na hora: eu quero "estrangular"; ele, até, não gostou. Disse que o médico era ele e que era para não ficar perguntando nada não, se ligou não... Mas eu tenho minhas dúvidas ainda se ele estrangulou viu? Ele não mostrou nada... Se eu voltar a ter outro filho o negócio vai pegar, viu?" (5.5)

"Eu sempre falava que eu não queria estar amarrada, queria que tirasse as trompas, por que não queria mais filho." (19.11) 
“[...] Mesmo assim tenho, sei lá porque as vezes muita gente, não sei se fez assim como eu fiz, mas muita gente que engravidou depois. Ainda tenho medo a menstruação não chegou ainda... Fico muito nervosa... Olha, eu fui fazer em São Gonçalo, a besta leva 16 pessoas ...faz todos os dias. Entrava de duas em duas. O quarto fica com oito camas: é muita gente." (19.15)

A desinformação deixa a mulher apreensiva com a possibilidade de gravidez, principalmente quando alguém, no seu grupo social já vivenciou o problema. Importante, destacar a parte da fala da entrevistada na altura em que revela que, ao tentar receber do médico, mais informações, recebe como resposta: "Disse que o médico era ele e que era pra ficar perguntando nada não, se ligou, não...".

$\mathrm{Na}$ visão de SERRUYA (1996), estes fatos acontecem porque, no decorrer de um longo processo histórico, estabeleceu-se uma relação assimétrica entre médico e paciente. Segundo ela, esta relação fundamenta-se no reconhecimento social da autoridade conferida ao médico, na sujeição dos indivíduos ao saber médico e na "docilização dos corpos".

VIEIRA (1998) discorrendo sobre a desinformação das mulheres, a respeito da esterilização, afirma que algumas desinformações são referentes ao modo como a técnica cirúrgica da laqueadura é interpretada pelas clientes. De acordo com as suas entrevistadas, as técnicas cirúrgicas podem ser descritas de duas maneiras: Uma operação que "corta" e outra que "amarra" as trompas. Muitas entrevistadas acreditam que a primeira é irreversível (definitiva), e a segunda pode ser revertida. A reversão poderia também acontecer espontaneamente em algumas situações especiais, como, por exemplo, após aumento de peso ou pela passagem dos anos. $\mathrm{O}$ médico foi citado como fonte dessas informações.

Esta autora, ainda, analisa a complexidade dessas informações, tendo em vista que envolvem idéias diferentes tais como: a falha da cirurgia, que pode ser considerada como auto reversão, e a comunicação, pouco efetiva, dos médicos com os clientes.

As representações que nossas entrevistadas fazem a respeito da técnica cirúrgica é que "estrangular" é sempre mais seguro do que "amarrar", uma vez que, 
no seu imaginário, este ultimo procedimento oferece, sempre, a possibilidade de falhas.

Para VIEIRA (1994) o problema é agravado pelo fato da esterilização ser identificada sob vários nomes diferentes: ligação, laqueadura, operação, e amarração de trompas para evitar filhos. Essas interpretações revelam ausência do direito de obter a laqueadura, corretamente informada sobre suas conseqüências.

\subsection{Outros}

Alguns outros motivos foram levantados pelas mulheres como impulsionadores para a decisão pela esterilização.

\section{Parto Difícil}

A experiência de partos difíceis e prematuros, da dor física, morte fetal, e mau atendimento hospitalar, notadamente, durante o pré-parto, parto e puerpério, foram colocados como motivos para pensar na interrupção da fecundidade.

"A gravidez foi ótima, mas o parto..." (4.2)

"Resolvi ligar por que já tinha 05 filhos,...Tive três partos complicados, o outro eu quase morro." (11.3)

"Como eu tinha tido um parto muito dificil, que ele quase morreu... nasceu todo laçado, a médica quebrou a clavícula... Eu, aí fiquei traumatizada de ter filho natural. Aí, eu decidi que outro filho, que eu tivesse, eu ia fazer cesárea: nesse período eu pensei, já que eu vou fazer cesárea, eu vou ligar." (13.4)

“[...] eu acho minha gravidez muito ruim, pois logo, no começo da gravidez, eu fico sangrando: esse mesmo foi de oito meses. O primeiro 
filho, que morreu, foi de sete meses... Eu tinha muito medo de parir a hora da dor, o medo de não parir logo de sofrer muito..." (18.6)

"[...] eu demorei muito de ter o menino. Eu sofri muito: me colocaram no soro, eu pensei que ia morrer, eu gritava tanto ... Eu sofri demais, demais! foi tanto que tive até problema respiratório." (18.7)

"E, também, eu não gostei do atendimento; acho que lá eles maltratam muito as pessoas; por isso tinha medo de ter filho, por causa disso. Ai, eu pensei: não quero mais filho, eu vou ligar. Aí, eu fui e liguei." (18.8)

ANDRADE (1997), encontrou também, referência ao parto difícil como motivo principal para decisão de esterilizar-se.

Para CECATTI e cols (1999), um aspecto importante, a se considerar, é a dor no trabalho de parto e parto e seu controle. Ainda que a falta de disponibilidade de recursos de analgesia sempre tenha sido apontada, como uma das responsáveis pelo número de cesáreas no País, pelo despreparo das mulheres em suportarem as dores, associadas ao processo, na verdade nunca se estudou verdadeiramente o assunto.

\section{Falta de Colaboração do Companheiro}

Apesar de somente uma entrevistada ter feito referência à falta de colaboração do companheiro na regulação da fecundidade, a literatura aponta para este comportamento masculino (OLINTO e GALVÃO 1999; HOGA 1996; CARVALHO e cols 2001).Vejamos o que diz esta fala:

"Depois a gente viu, o meu marido disse que ia fazer a vasectomia, mas aquela coisa de homem sabe como é, não é?" (6.11)

Para OLINTO e GALVÃO (1999), a baixa participação masculina não causa surpresa. O uso dos métodos anticoncepcionais masculinos (condom, coito 
interrompido, abstinência periódica e vasectomia), tem sido muito baixo, e, provavelmente, é menor agora quando as opções anticoncepcionais femininas são mais amplas do que no passado.

A percepção de CARVALHO e cols (2001), é que a menor participação do parceiro, na contracepção, pode indicar que a falta de participação masculina, no processo, é elemento relevante na opção por esterilização.

\section{Pressão Familiar}

A ocorrência de pressão familiar, no caso de uma das entrevistadas aconteceu porque aparentemente a família considerava que ela "aprontava" muito, não seguindo o comportamento idealizado pelo grupo social. O fato de "aparecer de barriga," por acaso, à margem das informações, e sem a devida consciência das questões na área reprodutiva, leva à tomada de decisão da família, à revelia da vontade da entrevistada:

“Eu nunca tomei remédio, eu tive a primeira menina, e teve muita confusão com meus pais... Aí apareci de barriga dessa menina (que tem 4 meses)...Aí minha mãe acertou a ligação prá mim." (8.1)

"Aí minha mãe falou: se tu não ligar, tu pega a menina e vai pró meio da rua. E eu disse: vou prá rua mais não vou ligar. Aí ela falou assim: é bom prá tu, porque tu pode trabalhar e não vai parir mais. A minha mãe acertou, e eu liguei." (8.3)

A mulher que tem algum problema de saúde, mesmo que construa sua própria família, pode acontecer de ter familiares (mãe, irmãos), que se sentem no direito de intervir na sua vida reprodutiva, mesmo que algumas patologias possam não intervir no seu poder decisório. A entrevistada até recebeu orientação de profissionais de saúde, mas tinha dúvida a respeito do procedimento, por medo de agravar a sua doença. Porém a família exerceu uma ascendência sobre seus atos, e ela, por insegurança obedeceu. 
“A minha família que mandou. E eu não podia falar nada, fiquei quieta. o meu marido aceitou. Eu só pensei que o meu problema ia piorar ligada." (9.4)

"A médica conversou. Ela disse que se eu ligasse, nova demais, mais tarde poderia ter problemas disse que eu podia usar o DIU de novo. Aí minha família me botou pra ligar e eu não podia fazer nada, fiquei quieta" (9.5)

BURSZTYN (1997) em inquérito domiciliar, realizado na Rocinha - Rio de Janeiro, encontrou 3,0\% das mulheres cuja decisão de se esterilizarem foi tomada pela família.

\section{Pressãa Social}

A representação de tamanho ideal de família, ocorre através da difusão de valores veiculada pelos meios de comunicação. Estas informações, às vezes, levam a mulher a se achar "diferente" por não está vivendo de acordo com os padrões estabelecidos. Começa, então a se sentir excluída do grupo social, por não estar vivendo de acordo com o esperado por aquele grupo. Desta forma, enfrenta o medo do processo cirúrgico, e parte para esterilização, como uma forma de ser aceita pelo grupo.Por exemplo: o número de gestações e filhos passou a ser, para esta entrevistada motivo de vergonha e humilhação:

"Também as pessoas diziam Ah! Hoje em dia pare quem quer: tem ligadura, tem como evitar tem tudo. A gente fica parindo fica com vergonha. Mas dizem assim: "existe remédio pare porque quer. Eu não, eu não tenho pena de uma mãe cheia de filho." Aí, a gente se sente humilhada." (10.8) 


\section{Aborto Provocado}

Muitas mulheres ficam grávidas sem ter desejado. A maioria dos casos, de gravidez indesejada, ocorreu por uso inadequado de métodos. Para MORAES FILHO e cols (1997), o desconhecimento e a falta de uso, de métodos anticoncepcionais de alta eficácia, associados à motivação de limitar o tamanho da família ou de espaçar o nascimento dos filhos, são, provavelmente, as principais causas do aborto provocado.

Antes da decisão do aborto, as mulheres tendem a considerar fatos financeiros, o relacionamento com o companheiro, e o número de filhos:

"Só tenho um filho. Tive um e um aborto, depois do aborto que eu liguei. Meu tem seis anos." (12.4)

“... durante o primeiro casamento eu tive um aborto... Eu não estava bem com meu marido e não queria o filho... Aí tomei o citotec... Aí, acabei abortando. Fui parar no balão de oxigênio e fiz a curetagem. Depois disso eu passei a me cuidar mais a ter mais cuidado."(13.3)

“Então, eu fiz três abortos... Eu estava tomando a injeção.” (19.10)

O aborto induzido é uma das causas de mortalidade materna. Segundo COSTA S H (1999), as mortes relacionadas com o aborto correspondem a $11 \%$ da mortalidade materna no Brasil, no período entre 1991 e 1993.

No estudo de MORAES FILHO e cols.( 1997), foi encontrado que a maioria das mulheres com aborto provocado, estava usando pílula, injetável, condom, tabela e coito interrompido. Deduz que, ao usar esses métodos, a mulher recebe aconselhamento $60 \%$ das vezes do balconista da farmácia, do marido ou da vizinha. E conclui, informando que há poucos estudos a respeito do conhecimento e uso de métodos anticoncepcionais, por mulheres hospitalizadas com aborto. E, quando estudos, desta natureza, são realizados, limitam-se apenas a indagar se as 
mulheres conhecem ou não conhecem, ou seja, "se já ouviram falar", não se obtendo informações se essas mulheres possuem um grau de conhecimento capaz de proporcionar uso seguro e correto desses métodos.

As mulheres se expõem ao risco do aborto, geralmente, por não contarem com serviços básicos de educação em saúde reprodutiva, problemas associados à baixa renda, e à estabilidade na relação com o companheiro. Enfim a gravidez indesejada, ocorre por falha dos métodos, geralmente por automedicação, ou por falta de informação correta sobre o uso dos mesmos. Estes motivos também foram encontrados no estudo de (HOGA 1996; COSTA S H1999).

COSTA S H (1999), faz referência a um estudo sobre razões para abortar, realizado no Rio de Janeiro em 1991, quando 39\% das entrevistadas relataram, que elas ou seus companheiros, simplesmente não queriam um filho naquele momento ou mais filhos no futuro. Outras $27 \%$ falaram que não tinham condições econômicas para criar outro filho. Concluiu então, que, mulheres no auge do período reprodutivo, ao abortarem, mais freqüentemente citaram, razões econômicas ou o desejo de não ter filhos. Sugerindo que suas preocupações variavam de acordo com a etapa de sua vida reprodutiva. 


\section{CONSIDERAÇÕES FINAIS}

Durante a elaboração deste estudo, deparamo-nos com vários aspectos que envolvem o tema da esterilização cirúrgica feminina. Inicialmente, encontramos a questão da queda da fecundidade, em grande parte, devido à realização da laqueadura tubária, fato que se registra em todas as regiões do País, com leves oscilações regionais. Um aspecto importante que se revela, é que a maioria dessas laqueaduras é realizada através da laparotomia ampla (feita durante a cesariana),o que, conseqüentemente, aumenta o número de cesarianas desnecessárias.

A história de políticas públicas do planejamento familiar leva-nos a refletir sobre o caráter progressista dos programas de saúde, como o PAISM, e a realidade da atenção à saúde da mulher. A falta de impacto desse programa, na população feminina, fica evidenciada tanto pelos indicadores epidemiológicos, quanto pela insatisfação dos usuários dos serviços de saúde. (COSTA A M 1999; BERQUÓ 1999; FORMIGA FILHO 1999; MARCOLINO 2000)

Os aspectos jurídicos, da esterilização regulamentada por lei, demonstram um avanço, considerando que, até antes da promulgação da Lei, a esterilização se realizava de forma clandestina, trazendo mais riscos à saúde da mulher. Embora a Lei no 9263 de 12 de janeiro de 1996 (BRASIL1998), vete alguns procedimentos, como a realização da esterilização no momento do parto, essa prática é, ainda, adotada em larga escala, principalmente entre as nossas entrevistadas.

A questão da esterilização se mantém como assunto largamente abordado junto aos setores progressistas os quais trazem à tona discussões sobre este assunto, sob a ótica do reconhecimento do direito da mulher ao seu próprio corpo, considerando que aquele que deseja esterilizar-se tem o direito de fazê-lo sem estar infringindo nenhuma norma ou direito (PIROTTA 1998).

A “cultura da esterilização," termo utilizado por BERQUÓ (1993), foi analisada sob a ótica da representação do método ideal, entendido pelas mulheres como solução para seu problema na área de reprodução. Trata-se de uma representação formada a partir das informações que receberam do meio social em que vivem, da mídia, principalmente a televisivas, e dos profissionais de saúde. 
Estes aspectos foram relevantes na compreensão dos motivos que levam as mulheres a escolha da esterilização, como forma de regular a sua fecundidade, $\mathrm{e}$ também, na proposição de uma discussão a respeito da importância dos serviços de saúde, no sentido que estes respondam às reais necessidades das mulheres na área de reprodução.

No presente estudo entrevistamos vinte mulheres que se submeteram ao método da esterilização. As informações colhidas, no que tange á contracepção, levaram-nos a pontuar algumas das representações, sobre os métodos contraceptivos reversíveis, que oferecem à mulher o suporte para a atitude de descartá-los como métodos anticoncepcionais.

- A pílula é representada como "fraca."A micropílula, quando em uso no pós-parto, "pode falhar", quando utilizada incorretamente, ou se esquece de tomar. E "dá muito mal-estar" por apresentar muitos efeitos colaterais.

- O DIU é representado como um método que dá "muito problema"(quando outras pessoas do grupo social fizeram uso e não se adaptaram); "dá medo" "porque tem um aparelho diferente dentro de mim", "porque faz correr muito" (quando aumenta o fluxo menstrual).

- O condom, como: "muito chato" e: um "método que falha" (existindo pouca aceitação entre casais).

- Coito interrompido, "não dá pra fazer" (pela dificuldade em adaptar-se).

- A tabela, como um método que há possibilidade de "fazer errado".

- Os injetáveis, como um método "que dá problema" (quando apresenta alterações menstruais, ou por informações negativas provenientes de outras mulheres).

Todos estes discursos, de alguma forma, indicam as representações negativas dos métodos reversíveis. Em contrapartida as representações a respeito da esterilização, são sempre mais positivas:

"Eu ligo e fico logo livre". Referindo-se à preocupação no uso diário da pílula.

"Não corro o risco de engravidar." Quando não deseja ter mais filhos. 
"Só ligada eu tenho certeza."

"A ligadura, eu acho mais seguro".

A representação negativa da esterilização só se registrou quando as mulheres se referem à dificuldade de acesso aos serviços oficiais para conseguir a ligadura tubária.

Os resultados permitem pensar que a opção pela laqueadura tubária, não representa uma negação à maternidade. Esta inferência fica muito clara na fala de duas entrevistadas:

"No começo nunca tomei remédio, ao contrário: fiz tratamento para engravidar." (1.1)

"Ai, depois fui fazer o tratamento para engravidar." (2.2)

O desejo da maternidade é confrontado com as vivências conturbadas com os métodos reversíveis que, em algum momento, levam as mulheres a optarem pela esterilização. A trajetória da mulher rumo à esterilização, se dá, de tal maneira, que a maioria delas já encerrou a sua vida reprodutiva aos 30 anos de idade.

Após um longo trajeto à mercê de métodos que não lhes dão segurança, que provocam efeitos colaterais indesejados, outros que não se adequam à mulher, a ela só resta a esterilização como recurso verdadeiramente seguro. $\mathrm{E}$ que, na maioria das vezes, não se traduz como opção, mas em absoluta falta de opção, em regular sua fecundidade, quando, naquele momento da vida, não deseja ter mais filhos.

Outras variáveis que foram levadas em consideração, principalmente, a satisfação com a prole e as condições sócio-econômicas, estão relacionadas com a representação de tamanho ideal de família, que vem diminuindo de tamanho, pela crescente urbanização das últimas décadas e a diminuição do poder aquisitivo das famílias. 
Nosso estudo encontrou que, em média, a mulher encerra sua vida reprodutiva após o terceiro filho. A representação é a de que, "nos dias de hoje, tendo menos filhos se cria melhor".

É importante ressaltar que as representações sobre os métodos contraceptivos reversíveis e a esterilização feminina, encontradas neste estudo, também se registram em outros, a exemplo de (MOREL 1992; MARCOLINO 1994; ANDRADE 1997; PIROTTA 1998; OSSIS 2001; CARVALHO 2001).

Os motivos, referidos pelas entrevistadas, que se constituem em razões que as levaram a optar pela esterilização são: "dificuldade como uso da pílula" seja por uso incorreto, pelos efeitos colaterais que provoca ou por falta de informação sobre o uso. "A dificuldade com outros métodos" por inadequação com os mesmos,e a total rejeição por "medo do DIU." Estas se constituem nas alegações freqüentes. Alie-se a estas a "A satisfação com a prole," ou seja, já crer contar com o número ideal de filhos, considerando as condições sócio-econômicas que vivem. O número de cesáreas aparece como uma das indicações médicas para a esterilização. Outros aspectos são, também, apontados, todavia, com menor freqüência como: "parto difícil" o que gera medo de outra gestação; a "falta de colaboração do companheiro" na regulação da fecundidade; "pressão familiar," por apresentar comportamento social não aceito pela família ou por apresentar patologia que a família considera incompatível com a maternidade; "pressão social" pela representação de tamanho ideal de família e, finalmente, "aborto provocado", por falha de métodos reversíveis. Outros estudos encontraram motivações geralmente compatíveis como as encontradas em nossas investigações. (MARCOLINO 1994; VIEIRA 1994, HOGA 1996; MINELA 1998; PIROTTA 1998; CORREIA 1998; MARCOLINO 2000; OSSIS 2001).

As entrevistadas revelaram, que escolhem o método contraceptivo que melhor se adeqüe às suas necessidades. A segurança de que não irá engravidar, sem desejar, faz parte de seu projeto de vida. Às vezes, pra possibilitar assumir novos papéis, outras, acreditando na melhoria de suas condições econômicas e de vida.

No que tange à informação sobre a esterilização, suas implicações e o conhecimento de métodos contraceptivos, evidenciou-se, na fala das entrevistadas, que a assistência à saúde reprodutiva mostra-se quantitativa e qualitativamente 
insuficiente; do que se depreende que a dificuldade de acesso a programas de planejamento familiar e a garantia de informação e gratuidade dos métodos não se traduzem em fato concreto na realidade dessas mulheres.

Talvez a rejeição a alguns métodos se deva à total falta de informação a respeito dos mesmos. Dados do PNDS dão conta da concentração no uso de pílula ( $91,4 \%$ das mulheres unidas, que usam algum método), que pode ser obtida em qualquer farmácia; e da esterilização, quando aquelas mulheres que já fizeram a opção, no núcleo social ou familiar, informam ser o método mais satisfatório e seguro (BEMFAM/DHS/MACRO 1997).

Outro aspecto que pudemos constatar, através das falas, é a solidão em que a mulher vivencia quando do controle da contracepção. A falta de participação do companheiro, nas práticas contraceptivas, transforma a mulher na única responsável, pela gravidez, contracepção e criação dos filhos. Esta situação acaba levando-a também, a solitariamente decidir pela esterilização, ficando para o companheiro, apenas, a assinatura da autorização do procedimento, ou pagamento do mesmo.

$\mathrm{O}$ acesso a programas de planejamento familiar, não se traduz em uma realidade para essas mulheres; seja por questão de horário de funcionamento, por suas atividades no lar, pelo cuidado com os filhos porque não têm onde deixar, ou, mesmo, pela falta de motivação para freqüentar estes programas.

Observa-se, também, a inexistência do processo dialógico entre as mulheres que desejam ser esterilizadas e a equipe de saúde. A isto, aliem-se as informações incompletas, que ocorrem, na maioria das vezes, no momento do parto ou pré-parto, levando as mulheres a decidirem por um método definitivo, sem ter a clareza necessária para esta tomada de decisão.

As informações colhidas, ao longo deste trabalho, serviram de subsídio para que formulássemos algumas recomendações, no sentido de otimizar o atendimento às mulheres no que diz respeito à contracepção.

Os achados, revelados neste estudo, mostram que é forçoso enfatizar a necessidades de orientação sistemática, informação e aconselhamento em saúde sexual e reprodutiva. Estamos convencidas de que não se pode descartar a importância da implantação do PAISM, nas unidades básicas de saúde, com ações 
voltadas para a promoção de informações adequando-as às necessidades das mulheres.

Que a prática conjunta de ações interdisciplinares, sejam desenvolvidas, pelos profissionais de saúde. E aqueles que trabalham nessas unidades, saibam reconhecer a importância, pra cada mulher, da queixa referida, e sejam capazes de avaliar o grau de compreensão na informação comunicada, para que, dessa forma as ações possam produzir o efeito desejado de esclarecimento, e, conseqüentemente, de liberdade de opinião na escolha de métodos contraceptivos.

É preciso, também, que os métodos reversíveis atendam à necessidade de segurança das mulheres, e que as pesquisas devam estar voltadas para a descoberta de métodos que atendam à facilidade de uso e reversibilidade, atenuando, assim, os efeitos colaterais.

Os resultados levantados apontam, ainda, para que seja mantida uma oferta de bons serviços de saúde, que inclua ações efetivas, na área de planejamento familiar, com equipes sensíveis às necessidades da mulher/casal, que o acesso a estes serviços seja facilitado, para que não haja demanda reprimida, e, que os horários de atendimento sejam compatíveis com as necessidades do casal ou, mesmo, da mulher que trabalha.

Ainda se faz preciso, a educação sexual de grupos de adolescentes para que as representações, já cristalizadas, em seu meio social e familiar, sejam revertidas através desta educação. À medida que providências desta natureza sejam tomadas, é possível que se propicie, a estes futuros adultos, escolher, de forma livre, consciente e informada a opção pelo método contraceptivo que irá adotar.

É de fundamental importância que se observe à necessidade, para as mulheres em idade fértil, terem acesso à Educação em Saúde, que deve ser utilizada como instrumento para alcançar efeitos intencionais sobre a saúde individual e coletiva, e é entendida, por CANDEIAS (1997), como quaisquer combinações de experiências de aprendizagem, delineadas com vistas a facilitar ações voluntárias conducentes à saúde.

A Educação em Saúde se constitui em uma parcela das atividades técnicas da Promoção em Saúde que, na definição de CANDEIAS (1997), é uma 
combinação de apoios educacionais e ambientais que visam atingir ações e condições de vida conducentes à saúde.

As ações, de promoção em saúde, estão previstas no modelo do SUS (Sistema Único de Saúde), e o seu novo paradigma está alicerçado em princípios de participação, inclusão e fortalecimento da cidadania. Essas ações são efetivadas não só através de legislação, mas principalmente, do desejo de gestores que proponham mudanças para transformação do cenário, com vistas a promover benefício da população no contexto de sua vida diária.

Na visão de CANDEIAS (1997), são muitos os princípios e os conceitos que fundamentam a prática de educação em saúde e promoção em saúde. A educação em saúde procura desenvolver mudanças de comportamento individual, enquanto que a promoção em saúde, embora inclua sempre a educação em saúde, visa a provocar mudanças de comportamento organizacional capazes de beneficiar a saúde de camadas mais amplas da população, particularmente, porém, não exclusivamente por meio da legislação.

Os resultados, demonstrados no presente estudo, revelam que os serviços de saúde que oferecem planejamento familiar e de atenção à saúde da mulher, em nível local, necessitam de reformulação objetivando implementar ações mais efetivas de educação em saúde. Também demonstram que os gestores municipais devam desenvolver ações de promoção em saúde, visando ao atendimento de atenção à saúde da mulher, de forma global, e principalmente no que diz respeito à saúde reprodutiva.

Para CHOR e FAERSTEIN (2000), são profundas as implicações da noção de que não somos totalmente independentes de nosso grupo social, nas escolhas de nossos hábitos de vida, já que o meio passa a ser enfatizado, tanto na forma das relações humanas, considerando-se a forte influência que o grupo social, com suas crenças e valores, exercem sobre o comportamento individual, quanto na adoção de políticas públicas que aumentem as oportunidades para adoção de comportamentos mais saudáveis.

Só a informação, a educação e o aconselhamento poderão transformar a opção pela esterilização em um ato pensado e analisado, com o conhecimento de todas as suas implicações e efeitos colaterais. Decisão que tomada com bases nesses 
conhecimentos, representa, para a mulher, o exercício do seu direito reprodutivo e de regulação da sua fecundidade.

Observou-se, também, a necessidade de que os formadores dos profissionais de saúde estejam aptos a motiva-los, no sentido de que sejam capazes de se envolver nos aspectos de saúde sexual e reprodutiva e, assim, aportar, não apenas uma visão biológica, mas de ser humano em toda a sua plenitude.

Outro aspecto que não nos passou despercebido é quanto à atuação da enfermagem, na área de saúde reprodutiva, pois esta deve ser repensada e norteada para a reestruturação do atendimento à cliente que busca um meio para regular a sua fertilidade. Os pré-requisitos norteadores desta reestruturação devem ter como eixo o respeito à cidadania e a promoção do ser humano

E, finalmente a nossa sugestão de que as políticas de atenção à saúde reprodutiva devem ser adotadas pelos gestores de saúde, de forma efetiva, para evitar as lacunas encontradas nos órgãos oficiais que, por este motivo, se tornam terrenos férteis para ação de oferta de esterilização de forma indiscriminada como a que se confirma nesta fala de uma entrevistada:

"Olha eu fui fazer em São Gonçalo. A "besta" leva 16 pessoas, ...faz todos os dias. Entrava de duas em duas. O quarto fica com oito camas: é muita gente." (19.16) 


\section{REFERÊNCIAS}

Albuquerque LA. Síndrome pós laqueadura. Existe? Femina 1985; 13(5): 406-409.

Andrade I P. Os nós da esterilização - A história de vida reprodutiva feminina no cotidiano de uma comunidade quilombola. Recife; 1997. [Dissertação de Mestrado - Universidade Federal de Pernambuco - Centro de Ciências Sociais Aplicada].

[Anonymus]. CREMEB suspende registro de Roland Lavinge. A Tarde, Salvador 2002, abr. 21; cad 1:3.

Assembléia Legislativa do Estado do Rio de Janeiro. Relatório Final da Comissão Parlamentar de Inquérito sobre Esterilização. Rio de Janeiro; 1991.

Assembléia Legislativa do Estado de Goiás. Relatório final da Comissão Parlamentar de Inquérito sobre Esterilização em Massa em Mulheres. Goiânia; 1992.

Arilha M. Contracepção em powerment e entitlement: Um cruzamento necessário na vida das mulheres. In Reflexões sobre gênero e fecundidade no Brasil (on line). Disponível em http://www.fhi.org/sp/barbrasp.[2000 ago 10].

Avila M B, Corrêa S. O movimento de Saúde e Direitos Reprodutivos no Brasil: Revisitando Percursos. In: Galvão L, Diaz J., organizadores. Saúde Sexual e Reprodutiva na Brasil: Dilemas e desafios. São Paulo: Hucitec Population Council, 1999. p. 70-150

Bacha C A. Epilepsia e Gravidez - Anticonvulsivantes. Femina 2001; 29 (7): 435 37. 
Barberi M. O enfermeiro na educação de adultos em planejamento familiar. São Paulo 1996. [Dissertação de Mestrado. Escola de Enfermagem da Universidade de São Paulo].

Bardin L. Análise de conteúdo. Lisboa: Edições 70; 1977.

Basted L L. Família sexualidade e reprodução no direito brasileiro. In: Giffin K, Costa S H, organizadores. Questões da Saúde Reprodutiva. Rio de Janeiro: Editora FIOCRUZ; 1999. p. 51-66.

Benfam. Pesquisa sobre Saúde Familiar no Nordeste do Brasil.Rio de Janeiro.1991.

Bemfam / DHS / MACRO (Sociedade Civil Bem-estar Familiar no Brasil / Programa de pesquisa e demografia e saúde / Macro Internacional). Pesquisa Nacional sobre Demografia e Saúde. Bemfam. Brasília; 1997.

Berquó E. Reflexões sobre gênero e fecundidade no Brasil. Núcleo de estudo de população. Unicamp: (on line). Disponível em $<$ http://www.fhi.org./sp/barbrosp.html> [1999 dez 07]

Berquó E. Esterilização feminina hoje. Ciência e Tecnologia. 1989; 88:598-610.

Berquó E. Brasil um caso exemplar - anticoncepção e parto cirúrgico - a espera de uma ação exemplar. Estudos Feministas, 1993; 1(2) 336-381.

Berquó E. Ainda a Questão da Esterilização Feminina no Brasil. In: Griffin K e Costa S H, organizadoras. Questão de Saúde Reprodutiva. Rio de Janeiro: Fiocruz; 1999. p 113-126.

Bordhal P E. Tubal Sterilization: a historical review. J. Reprod. Med. 1985; 30:1824. 
Brasil. Constituição da República Federativa do Brasil. Brasília: Senado Federal; 1998.

Brunett L S. Anamnese, exame e operações ginecológicas.In: Novak Tratado de Ginecologia.Trad .J Israel Lemos.11 a ed. Rio de Janeiro:Guanabara;1990.p.17-19.

Bursztyn I. Laqueadura tubária: um problema de saúde pública. Cad. Saúde Colet. 1997; 5 (1): 79-88

Candeias N M F. Conceitos de educação e de promoção em saúde: mudanças individuais e mudanças organizacionais. Rev.Saúde Pública. 1997; 31(2): 209-213.

Canesqui A M. A saúde da Mulher em debate. Saúde em debate 1984; 15/16: 29 36.

Carneiro A, Rodrigues $\mathrm{K} \mathrm{H}$. Opinião de mulheres de baixa renda, residentes em cidade do interior sobre planejamento familiar. Rev Bras Enf 1987; 40 (1): 23-27.

Carvalho M L O. Antecedentes e consequências da Esterilização Feminina: trajetória em busca do controle da própria fecundidade. São Paulo 2001 [ Tese de Doutorado - Faculdade de Saúde Pública da Universidade de São Paulo].

Carvalho M L O, Pirotta K C M, Schor N.Participação masculina na contracepção pela ótica feminina. Rev. Saúde Pública. 2001; 35 (1): 23-31.

Casani L, Guerra A E, Meneguzzi F, Bassanesi J C C, Brust L, Bergmann R,et al. Estudo multicêntrico sobre uso de anticoncepcionais orais, em amostra populacional de Caxias do Sul. Rev. Cient. AMECS. 1994; 3(2): 145-149.

Cecatti J G, Pires H M B, Goldenberg P. Cesárea no Brasil: Um direito de opção? In: Galvão L.; Diaz J, organizadores. Saúde sexual e reprodutiva no Brasil: Dilemas e Desafios. São Paulo: Hiutec - population Council 1999. 
Cesar J, Madeira A, Oliveira M, Hornk L, Fernandes L. Anticoncepcional oral e presença de fatores de risco entre mulheres de baixa renda em Pelotas, RS: um estudo descritivo. J. Bras. Ginecologia 1993; 103(9): 327-330.

Chor D, Faerstein E. Um enfoque epidemiológico da promoção da saúde: as idéias de Geoffrey Rose. Cad. Saúde Pública. 2000; 16(1): 241-244.

Corrêa S., Petchesky R. Direitos sociais e reprodutivos: Uma perspectiva feminista. PHYSIS: Rev. Saúde Coletiva 1996; 6(1/2): 147-77.

Correia GB, De Andrade RP, Mello CR, Martins AJ. Variáveis que sustentam a demanda da laqueadura tubária na visão das pacientes.Reprod.Clim.1998; 13 (2): 112-116.

Costa A M. Planejamento Familiar no Brasil. Bioética.1996;4(2):209-216

Costa A M. - Desenvolvimento e implementação do PAISM no Brasil. In Griffin K, Costa S H, Organizadores. Questões de Saúde Reprodutiva. Rio de Janeiro: FIOCRUZ; 1999; p. $319-335$.

Costa R G, Ossis M J D, Hardy E. Considerações sobre o processo de decisão pela laqueadura entre mulheres laqueadas no centro de assistência integral à saúde da mulher. Relatório final. Campinas 1995. Centro de Pesquisa das doenças materno infantil de Campinas

Costa S H. Aborto Provocado: a dimensão do problema e a transformação da prática: In: Giffin K e Costa S H, organizadores. Questão da Saúde Reprodutiva. Rio de Janeiro: Fiocruz, 1999; p. 163-184.

Daltro M E, Noronha C V, Menezes G M. Mulheres do recôncavo baiano e práticas anticonceptivas: Diferenças entre gerações. Informe epidemiológico do SUS 1992; Brasília, 1 (4): 33-41. 
Dias R, Nhás EAP, Rogenski O M, De Luca L A Viscomi F A Lopes RGC. Síndrome pós laqueadura - Repercursões Clínicas e psiquícas da pós-laqueadura: Rev Bras Gineco Obst. 1998; 20(4): 199 - 205.

Diaz M., Diaz J. Qualidade de atenção em saúde sexual e reprodutiva: Estratégia para mudança. In: Galvão L e Diaz J, organizadores. Saúde sexual e reprodutiva no Brasil: Dilemas e Desafios. São Paulo: Hucitec - Population Council; 1999.

Espín BA. El Síndrome de los Residuos Tubários (SRT) Postligadura y su sintomatologia. Rev de Obst e Ginec de Venezuela. 1981; 41(4): 243 - 250.

Esteves S C., Camargo M C Z A. A esterilização como método contraceptivo no Brasil - Determinantes sociais, éticos e morais. J. Bras. Ginec., 1991; 101 (11/12): 483-487.

Fagundes M L. Esterilização tubária - uma solução ou um problema? Femina 1993; $655-656$

Faundes A. e Hardy, E. Ética Médica e Planejamento Familiar no Brasil Rev. Bio [periódico on line]. 1999; 2 (4). Disponível em: <URL:http://200.239.43.3/cfm/espelho/eticamed.html [1999 Jul 03].

Faundes A, Costa RG, Pádua KS, Perdigão AM. Associação entre prevalência de laqueadura tubária e características sócio demográficas de mulheres e seus companheiros no Estado de São Paulo, Brasil. Cadernos de Saúde Pública (suplemento on line). 1998; 14. Disponível URL:http//www.scielo.br/egibin/fbpe [2000 mai 17].

Formiga Filho, JFN. Políticas de saúde reprodutiva no Brasil: uma análise do PAISM In: Galvão L e Dias J, Organizadores. Saúde sexual e reprodutiva no Brasil: Dilemas e Desafios. São Paulo: HUCITEC Population Council; 1999. 
Fundação IBGE. Censo demográfico: resultados preliminares - Bahia. Rio de Janeiro; 2000.

Gentile GP, Kaufman. SC, Helbig DW - Is there any evidence for a post-tubal sterilization syndrome? Fertility and Sterilily. 1998; 69(2): 179- 186.

Gerber S, Caetano J P J. Interferência da salpingotripsia na vascularização ovariana e uterina.Estudo dopplerfluxométrico. Reprod. Clima.1999;14(1):31-35.

Giffin L, Costa S. As práticas contraceptivas e o aborto no Brasil. Núcleo de estudo de população. Unicamp [on line]. Disponível em http://www.fhi.org./sp/barbrosp.html [1999 Dez 07].

Guareschi P. Sem dinheiro não há salvação: ancorando o bem e o mal entre neopentencostais. In: Jouchelovitch, S., organizadores. Textos em representação social. 2a ed. Petropólis: Vozes, 1997 p. 191 - 223.

Hardy E E, Moraes T M, Faundes A., Vera S, Pinotti J A, Adequação do uso de pílula anticoncepcional entre mulheres unidas. Rev. Saúde Pública 1991, 25 (2): 96 $-102$

Hardy E; Ossis M I D, Faundes A, Alves G. Pinotti J A. A laqueadura tubária precoce durante a cesárea: dimensões atuais e fatores que a determinam Rev Ginecol Obstet. 1993;4(3):70-76

Hatcher R A. et al Planejamento familiar. Tradução Dr. Carlos Roberto Oliveira Rio de Janeiro: Ao Livro Técnico; 1983.

Hoga, L A K A Mercê do Cotidiano da anticoncepção: a mulher seguindo o seu caminho. São Paulo; 1996. 
Jones $\mathrm{H}$ W, Jones G. S. Novo tratado de ginecologia. Rio de Janeiro: Guanabara Koogam; 1990.

Jordelet D. La representacion social: fenomenos, conceptos y teoria. In: Moscovici S. Psicologia Social: pensamento $\mathbf{y}$ vida social, psicologia social $\mathbf{y}$ problemas sociales. Vol. 2 Barcelona - Buenos Aires - México: Paidós; 1986 p. 469-94.

Marcolino C. Trajetória da mulher em direção a esterilização cirúrgica feminina: um estudo fenomenológico. São Paulo; 1994. [Dissertação de Mestrado Faculdade de Saúde Pública da USP].

Marcolino C. Análise do Trabalho de uma equipe de Saúde acerca da laqueadura tubária - Estudo de caso de Belo Horizonte. São Paulo; 2000. [Tese de Doutorado - Faculdade de Saúde Pública da USP].

Martins C M. Fecundidade Paulistana - Um estudo de seus diferenciais intra urbanos de desenvolvimento humano e escolaridade. São Paulo; 1999 [Dissertação de Mestrado. Faculdade de Saúde Pública da USP]

Médici A C. Beltrão H.I. Financiamentos dos programas de planejamento familiar no Brasil: estratégias econômicas de sustentação - São Paulo FUNDAP, 1995. (on line) disponível em http://www.fundap.sp.gov.br/info[2000nov. 13].

Melo NR, Neme RM, Giribela AHG, Gonçalves SP, Sacilotto MTJ, Pinotti J A.. Contracepção em mulheres com epilepsia: estudo de 25 casos. RBM- Caderno de Ginecologia e Obstetrícia,1995; 5:6-10.

Merighi M A B, Barrentos D S; Montano R S, Kimura A F. Repensando a assistência sobre planejamento familiar. Rev. Med. HU-USP, 1997; 7: 30-35

Minayo M C da S. O desafio do conhecimento - Pesquisa Qualitativa em Saúde $3^{\text {a }}$ ed. São Paulo/Rio de Janeiro: HUCITEC - ABRASCO; 1994. 
Minella L S. Aspectos positivos e negativos da esterilização tubária do ponto de vista de mulheres esterilizadas. Cadernos de Saúde Pública [suplemento on line] 1998; 14. Disponível em <URL:http//www.scielo.br/egi-bin/fbpe> [2000 mai 17]

Ministério da Saúde. Assistência Integral à saúde da mulher: bases de ação programática. Centro de Documentação do Ministério da Saúde, Brasília, 1984.

Ministério da Saúde. COSAM/SAS. Coletânea de documentos do PAISM. Brasília, $1985-1997$

Ministério da Saúde. Assistência ao Planejamento Familiar. Brasília, 1996.

Ministério da Saúde, Secretaria da Assistência à Saúde. Portaria no 144 de 20.11.1997: regula o $\S 7^{\circ}$ do art 226 da Constituição Federal que trata do Planejamento Familiar. Diário Oficial. Brasília 24 de nov. 1997. Secção, p. 27409.

Ministério da Saúde. Coordenação da Saúde Materno-Infantil. Assistência ao Planejamento Familiar. Brasilia (DF): COSMI; 1992 (Série A: Normas e Manuais Técnicos). 158p.

Ministério da Saúde. Saúde da mulher: Planejamento Familiar (on line). Disponível em < URL:http://www.saude.gov.br/programas/mulher/planej.htm> [1999 Jul 03].

Molina A. Laqueadura tubária: Situação nacional e internacional e efeitos colaterais. In: Griffin K e Costa SH, organizadores. Questões de Saúde Reprodutiva. Rio de Janeiro: Fiocruz; 1999. p. 127-145.

Moscovici S. Sobre representações sociais. Tradução: Cláelia Maria Nascimento. Shulze. Paris: [s.n.] 1985 (mimeografado)

Moraes Filho O B, Albuquerque R. M., Hardy E. Conhecimento e uso de métodos anticoncepcionais por mulheres com aborto provocado ou espontâneo. Revista do IMIP. 1997; 11(1): 32 - 41 
Morell M G G P. A prática de esterilização em São Paulo: Uma tentativa de caracterização. In:VIII Encontro Nacional de Estudos Populacionais, 1992, Caxambú. São Paulo, Associação Brasileira de Estudos Populacionais, 1992. V 2 p. $61-82$.

Nobrega S M. O que é representação social. Paris: [s.n.]. 1990 (mimeografado)

Olinto M T A., Galvão L W. Características reprodutivas de mulheres de 15 a 49 anos: estudos comparativos e planejamento de ações. Rev. Saúde Pública. 1999; 33 (1): 64-72.

Oliveira M A C. A política de reprodução Biológica Humana no Brasil. Rev Saúde Pública 1992; 25 (2):155-60.

Oliveira D C. Representações e Saúde Pública: a subjetividade como participe do cotidiano em saúde. Rev. de Ciências Humanas. 2000; (Ed. Especial Temática); 47 -65 .

Oliveira E A A. Laqueadura: a realização de um sonho para mulheres de uma comunidade. São Paulo. 2000 [Dissertação de mestrado - Escola de Enfermagem da Universidade de São Paulo]

Organización Mundial de la Salud. La Educación Sanitaria en la Planificación de la Familia. Genebra; 1971 (Série de informes Técnicos, 483)

Ossis MJD, Hardy EE, Simões IRS, Vera S, Faundes A. Laqueadura tubária nos serviços de saúde ao Estado de São Paulo. Revista de Ginecologia e Obstétrica 1990; 1: 195-204.

Ossis M J M D, Faundes A, Sousa M H, Bailey P. Conseqüências do uso de métodos anticoncepcionais na vida das mulheres; o caso da laqueadura tubária. Cad. Saúde Pública. 1999; 15(3):521-532. 
Ossis M J M D. Laqueadura e representações acerca da sexualidade e do papel reprodutivo, São Paulo 2001.[Tese de Doutorado - Faculdade de Saúde Pública da USP].

Patarra N L, Carvalho J A M. Transição, Transições. In Anais do VI encontro sobre demografia. Olinda 1988. (on line) disponível em http://abep.nepo.inicamp.br[2002 maio 10].

Perdigão A M. Evolução da prevalência da laqueadura tubária. Associação com variáveis demográficas e sociais das mulheres e de seus companheiros Campinas 1996. [Dissertação de Mestrado - Faculdade de Ciências Médicas da Universidade Estadual de Campinas]

Pessini L., Barchifontaine C P. Políticas populacionais e direitos reprodutivos. In: Problemas atuais de Bioética. 5ª ed. São Paulo. Ed. Loyola; 2000.

Pinotti J A, Diaz A J, Diaz M M, Hardy E, Faundes A. Identificação de fatores associados à insatisfação após esterilização cirúrgica. Gin. Obst. Bras. 1986 $9(4): 152-156$.

Pirotta K C M. A mulher e a esterilização: Do mito da emancipação ao desvelamento da subalternidade. São Paulo 1998 [Dissertação Mestrado Faculdade de Saúde Pública da USP]

Pirotta K C M., Schor N. Carências e desejos: estudo da opção pela esterilização entre mulheres residentes na Região Sul do Município de São Paulo, em 1992. Saúde e Sociedade, 1999; 8 (2): 33-57.

Pollack A E. Esterilizacion masculina e feminina: consequências a largo prazo para la salud. Outlook 1993; 11:1-8. 
Sá CP. A construção do objeto de pesquisa em representações sociais. Rio de Janeiro: Ed UERJ; 1998.

Secretaria de Saúde do Estado da Bahia,. Manual de prestação de serviços em saúde reprodutiva. Primeira edição. Salvador, 1998.

Sempreviva Organização Feminista - SOF - Esterilização feminina caminhos e Descaminhos São Paulo 1994 ( Seru Saúde e Direitos Reprodutivos, Vol I).

Serruya S. Mulheres esterelizadas: submissão e desejo. Belém: NAEA/UFPA/UEPA, 1996.

Silva L M. Coordenador. Mulher e planejamento familiar. Belo Horizonte: UFMG/Núcleo de Pesquisa sobre Mulher; 1986.

Silva M C M., Hoga L A K., Ferreira B A., Métodos Anticoncepcionais: Análise de uma população rural. Âmbito Hosp. 1990; 11( 20): 7 - 11.

Spink M J P. O conceito de representação social na abordagem psicossocial. Cad. Saúde Pública, Rio de Janeiro. 1993; 9(3): 330-338..

Sudbrack A W. Fertilidade Domada - Esterilização voluntária feminina em Vila Popular de Porto Alegre. Porto Alegre, 1994 [Dissertação de mestrado Universidade Federal do Rio Grande do Sul].

Triviños A N S. Introdução à Pesquisa Social em Ciências Sociais. São Paulo: Atlas; 1992.

Vala J. Análise de conteúdo. In: Silva A S, Porto J M., organizadores. Metodologia das Ciências Sociais. Porto: Afrontamento; 1986; 101 - 126. 
Valadão M M. Estudo do uso e conhecimento dos métodos anticoncepcionais pelas professoras da rede Pública de ensino num município do alto Vale do Paraíba - Estado de São Paulo. São Paulo, 1990 [Dissertação de Mestrado Faculdade de Saúde Pública da USP].

Vieira E M. O arrependimento após esterilização feminina. Cadernos de Saúde Pública (suplemento on line) 1998; 14(1): 59-68.

Vieira E M. A esterilização em mulheres de baixa renda em região metropolitana do Sudeste do Brasil e fatores ligados à sua prevalência. Rev Saúde Pública. 1994; 28(6): $440-448$.

Ziegel EE, Cranley MS. Enfermagem Obstétrica. $8^{\mathbf{a}}$ ed. Rio de Janeiro: Interamericana; 1985. Fertilidade, Infertilidade e controle da concepção; p.106119. 
A NEXOS 
Anexo 1 - Ficha de Identificação

Ficha de Identificação

1. Nome

2. Endereço

3. Ponto de Referência

4. Idade

5. Situação conjugal

6. Ocupação principal

7. $\mathrm{N}^{\circ}$ de gestações $N^{o}$ de Partos: Normais

Cesárea

Abortos

8. Foi a escola? Sim Não

8.a. Qual a série completou? ano do

9. Data da visita Horário 


\section{Anexo 2 - Termo de Responsabilidade do Pesquisador}

Prezada Senhora

A ligadura de trompas vem crescendo muito nos últimos anos entre as

mulheres no Nordeste como um dos métodos para evitar gravidez. É muito importante para nós sabermos os motivos que levam as mulheres a escolher esta forma de controle de natalidade.

Sou enfermeira e aluna de doutorado da Universidade de São Paulo e estou realizando uma pesquisa que pretende conhecer porque a mulher escolhe este método.

Desta forma, quero lhe convidar para contribuir com esta pesquisa. Sua contribuição será responder a uma entrevista, em sua residência. Na entrevista serão feitas perguntas sobre a sua história de gravidez, e uso de outros métodos anticoncepcionais.

É importante que você saiba que as informações fornecidas nas entrevistas serão sigilosas e utilizadas apenas nesta pesquisa. Seu nome, seu endereço ou qualquer outra informação que possa lhe identificar não aparecerão em nenhum tipo de publicação, nem serão revelados a outros profissionais de saúde.

Caso você não aceite participar da pesquisa nada mudará em seu atendimento aqui no hospital. Caso aceite, durante a entrevista, também poderá interromper sua participação no momento que desejar sem nenhum problema. Se você tiver dúvida sobre a pesquisa ou sobre sua participação sinta-se à vontade para perguntar e de me contatar.

Agradeço sua cooperação.

Atenciosamente

Neuza Teixeira de Carvalho

Doutoranda USP / UEFS

Telefone de contato: 224.80 .96 (UEFS) 


\title{
ANEXO 3 - Entrevistas
}

\section{Entrevista I}

Pergunta 1: Como você fazia para evitar filhos desde o começo de sua vida sexual?

\begin{abstract}
Ah, na verdade eu no começo nunca tomei remédio nenhum ao contrário eu fiz tratamento para engravidar na época eu já trabalhava ai fiz o tratamento. Fui na clínica e conversei com o médico, era louca para ter um filho.Ai ele disse vamos fazer o tratamento; siga corretamente que vai dar tudo certo. Ai com oito meses que fiz o tratamento engravidei a primeira filha tem oito anos.Ai eu dei um tempo ele me passou o remédio, o anticoncepcional eu tomei, passei três anos tomando e por uma falha eu engravidei, acho que foi o remédio mesmo que já estava fraco. O meu marido falava "vai mudar esse remédio" ai estava tudo certo para mudar, ai quando aconteceu eu deixei e pensei "quando eu ter o segundo eu ligo", queria ligar, mas passei mais quatro anos usando pílula e quando já estava pronta para colocar o DIU, engravidei do meu agora. Ai pensei do terceiro agora eu ligo, não quero nenhum filho a mais.
\end{abstract}

Pergunta 2: Como você decidiu fazer a ligadura de trompas?

Eu decidi porque minhas colegas falavam comigo... Tenha mais um filho e eu sempre pensava comigo depois que eu ter três filhos eu ligo, não quero DIU não quero nada, eu vou ligar. Ai eu conversei com o médico, antes de engravidar, do nenê eu já estava com ele, ele atende muito bem é um ótimo ginecologista e ele disse... Ai eu ia fazer a cesariana. Mas aconteceu que ele marcou para o dia 15 e eu tive no dia 12, ia fazer tudo junto. Eu não cheguei a conversar com ele se ia ser pelo SUS ou se eu ia pagar uma taxa porque o meu convenio cobria e não cobre mais. Eu queria ligar por que eu só queria três filhos.

Eu penso assim se eu continuar tomando remédio um dia vai falhar e eu não queria usar o DIU também não queria usar a injeção; porque minhas colega lá tem umas três que usam a injeção e minha prima usa a injeção direto e sempre tem problema eu fiquei com medo, ela sempre tem problema...

Pergunta 3: Você teve alguma informação sobre a ligadura de trompas? De quem?

Eu só perguntei ao Doutor: doutor quando eu tiver esse nenê. Quando eu engravidei logo que comecei a fazer PRÉ-NATAL com ele eu disse: olhe doutor eu quero ligar eu não quero mais ter filho não, pra mim já chega. Ai ele perguntou quantos anos você tem, se tinha algum problema pressão de diabetes e eu disse: graças a Deus não tenho nada. (porque na gravidez eu controlei muito, mas eu estava com um pouco de pressão alta e eu comecei a controlar fazendo dieta, ai graças a Deus a pressão ficou ótima, na família tem gente que tem diabetes, pressão alta, minha mãe mesmo tem). Ai ele disse ta bom qual é mesmo a sua idade e eu disse: Não doutor pela minha idade acho que ta bom e ele disse se Deus quiser eu lhe ligo.

Minas duas colegas e duas primas e duas irmãs que ligaram não sentem nada, já outras disse que tinham problemas depois que ligou, dor nas pernas, dor na barriga tantas coisas... Mas eu tenho certeza que não é um bicho ruim não; porque a vizinha aqui de frente mesmo tem 13 anos de ligada e diz que está ótima não sente nada o único problema dela é a pressão. Ela tem 38 anos e já teve 11 filhos e pesava 136 quilos. 
Mas eu queria que um profissional chegasse pra mim e explicasse como é esse negocio de ligação. Eu já tinha conversado com o médico pra ele fazer e depois que tive o nenê fui lá e ele marcou pra fazer tem três meses que eu tive o nenê e não passei no planejamento do hospital. Agora, eu já participei do planejamento do Hospital Clériston, mas ainda não pensava em ligação. O meu marido gostou de eu ter feito, porque ele é uma pessoa casada e tem mais três filhos.

Agora se fosse pra fazer com os políticos eu não fazia não é tudo nas carreiras, mas tem duas primas que fez e gostou, uma fez em S. Gonçalo e outra em Sta. Bárbara. Graças a Deus não sentem nada pegam o carro e vão fazer.

\section{Entrevista 2}

Pergunta 1: Como você fazia para evitar filhos desde o começo de sua vida sexual?

Bom, eu tomava anticoncepcional e ai eu parei para engravidar; engravidei duas vezes e perdi por causa do meu tipo de sangue que é negativo e eu não sabia; um foi com dois meses e o outro com três de gravidez. Ai depois fui fazer o tratamento para engravidar, só que eu já estava grávida e não sabia, ai tomei remédio para segurar, o dactil ob, segurou a menina. Quando eu tive a menina tive que tomar a vacina e graças a DEUS, depois eu estava amamentando a menina e tomando o micronor, só que o Micronor já estava ficando fraco e eu não mudei e ai engravidei do menino ai também eu deixei e resolvi ligar foi justamente por causa do tipo do sangue cada vez que cu tivesse um filho tem que tomar a vacina, né? E minha gravidez também são meio enjoada \{pedi para me explicar melhor\} Enjoada assim, eu tenho enjoou do dia que engravido até o dia de parir.

Nunca freqüentei serviço de planejamento às vezes o médico passava as pílulas ás vezes eu comprava na farmácia quando eu engravidei da menina \{primeira filha\} é que fiz todos os exames e deu Rh negativo, quando eu fui pró-médico que fez os exames eu descobri, ele disse que eu tinha o Rh negativo e que tinha que ter repouso, e muito cuidado com a gravidez para que não acontecesse o aborto. Assim que eu descobri que estava grávida, descobri não, eu fui porá o médico para fazer o tratamento, ai ele fez uma endovaginal e até brincou comigo, dizendo que eu estava no período fértil, mas, eu acho que ele já viu porque com a endovaginal se ver tudo né? Ai ele passou todo tipo de exame que mulher grávida faz, ele passou pra mim, ai eu fiz, ai quando eu voltei já estava sentindo enjoou, ele já me deu medicamento para enjoou e me deu remédio para segurar o nenê e pediu que eu tivesse muito repouso. Ai eu tive nenê e fui a outro médico, ai comecei a tomar o Micronor e ai com seis meses que, a menina já tinha mais de seis meses, ai o médico falou para eu mudar que o remédio estava fraco, mas só que eu fiquei com medo, porque os anticoncepcionais têm muito hormônio e eu fiquei com medo de passar para a menina, porque também ela nasceu com refluxo e ai eu fiquei com medo e disse: não eu vou tomar esse fraquinho mesmo. Ai quando eu descobri já estava grávida do menino, e eu ainda estava amamentando ela hoje tem um ano e nove meses.

\section{Pergunta 2: Como você decidiu fazer a ligadura de trompas?}

$\mathrm{R}$ : Eu pensei assim: eu tive muitos problemas quando tive ela, fiquei muito preocupada para tomar a vacina, na época meu marido estava praticamente desempregado, e eu criei um medo de acontecer à mesma coisa com este, quando eu tivesse este de tomar a vacina que custa um salário mínimo ou mais, na época o salário mínimo era 131 e a injeção foi 143 , mais de um salário né? Ai eu resolvi que devia ligar, eu já tenho dois filhos crio um menino e ai eu falei três está bom demais, porque ele não é meu filho, mas eu crio, é a mesma coisa, ai eu conversei com meu marido ele achou e a minha sogra também achou de acordo. 
Pergunta 3: Você teve alguma informação sobre a ligadura de trompas? Por quem foi dada?

R: Conversei com a enfermeira que fazia meu Pré-natal, ela achou assim, que justamente por causa do meu tipo de sangue a melhor maneira de evitar era ligando, ela não me falou de todos os métodos, ela me falou que realmente eu tomando remédio de evitar eu tinha possibilidade de engravidar, falou também que eu podia usar o DIU, mas eu fiquei com medo porque geralmente as mulheres não se dão bem com o DIU e ai eu achei melhor não colocar.E ai o médico disse: é uma decisão sua e ai programou para fazer no parto e mesmo que não fizesse eu ia fazer depois. Minhas gravidez eu tenho suspeita de aborto, muito enjoou, fico mole, normalmente o povo diz que gravidez é saúde, mas, a minha não. $O$ médico me disse que eu podia me arrepender, mas eu disse a ele que Jesus não ia deixar cu me arrepender, porque hoje em dia está tão difícil criar filho, as dificuldade da vida está muito grande e não adianta você ter três, quatro, cinco, filhos e não poder criar nem educar meu pensamento é esse, porque o principal para a criança é a educação, se você não tem pra dar, adianta encher de filho e viver todo mundo ai abandonado sem escola, em saúde e sem alimento.

\section{Entrevista 3}

Pergunta: Como você fazia para evitar filhos, desde o começo de sua vida sexual ?

Primeiro usei camisinha, mas não gostava de camisinha, achava muito chato e ai depois eu comecei a usar a pílula, o microvilar, só que eu era muito esquecida eu tenho filhos e todos os 4 filhos são frutos do esquecimento, eu esquecia mesmo. A gente tem o costume de dizer ah! a pílula falhou, mas não era que falhava era que eu realmente esquecia né? Ai passei um bom tempo, mais ficava muito preocupada, porque esqueci de tomar e quando lembrava, dizia ai meu Deus esqueci... ai depois voltei a usar a camisinha novamente, e ai disse: "olha é melhor eu ligar porque pelo menos eu ligo e fico livre, e não fica essa preocupação de tomei não tomei, c ai resolvi ligar". Todos os partos foram normais e eu amamentava muito tempo, nem senti nada com a pílula, as pessoas dizem que enjoavam, ficavam com dor de cabeça, mas nunca senti nada, era com se eu não tivesse sentido nada.

Pergunta: Você nesse período frequentou o planejamento?

Só duas vezes, eu só fui duas vezes no planejamento familiar, e não fui mais, também não tinha tempo, eu trabalhava o dia todo só chegava em casa à noite.

Pergunta 2: Como você decidiu fazer a ligadura de trompas?

$\mathrm{Na}$ realidade, desde a $2^{a}$ filha que eu já pensei em ligar, mas sempre que eu procurava, o posto de saúde, tinha aquela dificuldade, por que ah! Não podia ligar, por que ainda estava cedo e sempre aquela dificuldade e ai quando engravidei da última menina eu já estava com... vou fazer 33 agora, então eu falei com o médico: “ ô Dr. Eu preciso eu já tenho a Quarta filha e eu preciso ligar "e ai eu conversei com uma amiga minha que trabalha no hospital que eu liguei, e ai ela ajeitou lá, e eu fui na palestra duas vezes lá, e o termo de responsabilidade meu marido assinou, e ai ele marcou comigo.

Pergunta 3: Você tem alguma informação sobre a ligadura de trompas? Por quem foi dada?

Não, a única coisa que eles me perguntaram é se eu tinha consciência do que eu estava fazendo, se meu marido concordava, que eu tinha de assinar um termo de responsabilidade, e 
meu marido também, e só poderia ligar se meu marido assinasse. Ele foi lá comigo e foi isso que passaram prá mim. Se tinha assim algum perigo, alguma coisa, não foi passado prá mim, as consequências, eles não passaram.

Porque também eu nem culpa ninguém lá eu culpo a mim mesmo, porque eu não fui fazer o planejamento, só fui a duas palestras a pulso, com certeza eles dizem tudo nas palestras, mais por eu não ter ido, vou dizer que foi erro deles eu é que não fui, mais com certeza eles devem dizer lá o que acontece, o porque.

Eu falei com o médico que eu não tinha condição de pagar a ligadura, ai eu pedi a ele que ligasse (esse médico era particular) eu também achei condição de ligar fora mas eu não queria porque tenho muito medo dessa ligação e aquele negócio de um monte de gente rápido e de repente todo mundo já ligou e já voltou, e eu ficava pensando: "será que essa ligadura é segura?" eu ficava com medo né, se bem que na verdade também eu ainda tenho um pouco de medo porque eu não quero mais ligar de jeito nenhum e fiquei assim...

Pergunta: Tem um pouco de medo de que?

De engravidar novamente, que eu não quero mais engravidar. Eu conheço pessoas que... no dia mesmo que eu fui, tinha 2 mulheres lá que eram ligadas e que estavam grávidas e ai eu pensei: será que realmente está ligada? É isso ai.

Pergunta: Mas você já conhecia o médico?

Conhecia, mas na realidade, quando chegou no dia eu não dei sorte, porque ele não pode ir, e ele passou prá outro médico que fez a ligadura.

Pergunta: E foi isso que lhe deixou insegura?

Foi, ele tinha marcado cesárea, prá mim fazer cesárea, e ligar ai quando chegou lá a médica disse que não ia fazer cesárea de jeito nenhum, que ela só faz em último necessidade, ai ela disse eu vou internar e se você der sorte de parir (dentro do período do plantão) eu ligo se não..., ai fiquei, tive parto normal, ai depois que tive o parto foi que ela ligou. Não foi pelo fato de ser normal, foi pelo jeito dela, e ai eu fiquei pensando será que ela ligou mesmo? Eu sai da sala de parto para o centro cirúrgico. Ela me disse: olha aqui. Oh! Estou cortando sua trompa ,tomara que tenha cortado mesmo porque as coisas estão tão difíceis não é brincadeira pra a gente pagar escola do jeito que as coias estão e também hoje em dia com muitos filhos você não pode trabalhar,eu estou sem trabalhar, é difícil achar uma pessoa de confiança pra deixar.Então foi tudo isso que me levou a ligar.Porque se eu não tivesse ligado estava correndo risco de engravidar novamente.

Pergunta: Você conhecia outros métodos além da pílula e camisinha?

Ah! Eu conheço o DIU, mas minha irmã teve um problema com o DIU e eu não quis. Cheguei a fazer coito interrompido mas não deu.

O médico chegou a falar em eu me arrepender mas eu disse que não ia me arrepender. Minha mãe queria que eu parasse na segunda menina dizia menina pra que mais filho, e ficava preocupada por causa das minhas varizes, quando eu engravidava até a vagina ficava uma"laranja", e ela ficava com medo de estourar e eu morrer, tinha muitas varizes muitas mesmo.Infelizmente quando engravidei da quarta, ela não estava mais aqui. 


\section{Entrevista 4}

Pergunta 1: Como você fazia para evitar filhos desde o começo de sua vida sexual?

Eu logo quando casei comecei a tomar anticoncepcional,ai com dois anos e meio por ai eu parei porque tive um problema de inflamação, essas coisas ai eu parei o remédio, fui ao médico, fiz tratamento e tudo. Logo que eu parei de tomar o remédio eu engravidei, tive o menino. A gravidez foi ótima mas o parto foi... comecei a ter dor oito de noite e só fui ter no outro dia quatro da tarde ; assim mesmo só foi o tempo de ter, porque assim que tive desmaiei, só ouvi a enfermeira dizer é menino.Quando acordei já era nove da noite, e eu tive anemia profunda, perdi muito sangue, acho que foi a placenta que ficou e ai lutaram para tirar, né.. Ai pronto, depois,tive em novembro, quando foi em janeiro fiz revisão, ai já pedi o anticoncepcional pra tomar. Tomei durante onze anos, só que durante esse tempo começou a sair umas manchas vermelhas no corpo e nada, eu ia a médico, médico, médico. O primeiro foi dermatologista, fez vários testes e nada. Ai passei pra o ginecologista; começou a trocar o anticoncepcional, a mudar e mudar e ninguém resolvia. Quando pensou que não... no ano passado eu tive uma dor; que dor foi essa que fui parar no hospital, fiquei internada durante quatro dias, só que o médico não me operou e me deu alta. Com uma semana eu tive uma dor forte, e ai fui e tirei uma ultra e endo, ai a médica disse: você tem que se operar agora e já. Ai fui providenciar o hospital pra operar. Era que os comprimidos acumularam na trompa, então foi preciso tirar. Já estava em estado de hemorragia, quando ele abriu e ai foi tirada a trompa e feito a biopsia, e tiraram a trompa esquerda e o ovário esquerdo, ai o médico disse que não convinha né? Que depois de três a quatro meses eu fosse fazer a revisão e que tinha que fazer o resguardo de 45 dias, dei o resguardo e tudo. Só que fui fazer a revisão com quase seis meses, quando fui ver já estava grávida.

Pergunta: Me explique melhor, foi dito que os comprimidos se juntaram nas trompas? Não foi gravidez não?

Não, foi aberta a trompa, logo no início na ultra suspeitaram de gravidez nas trompas, mas quando o médico abriu e tirou não foi filho não. Agora como esses ficaram lá dentro eu não sei. Quando fui na revisão já estava grávida com uma trompa só e eu fiquei com medo. Mas o médico que estava tudo em paz e que era eu seguir o pré- natal direitinho, e mês a mês passo a passo a médica acompanhou, ele estava se desenvolvendo bem, e eu não tive problema nenhum na gravidez. Devido a cirurgia que eu tinha feito, já estava no processo infeccioso né, então eu fiquei assustada, e veio ele.

Pergunta 2: Como você decidiu fazer a ligadura de trompas?

Decidi por causa de minhas condições financeiras.Meu marido bebe,eu não tinha condições nenhuma de ter, eu já estava desempregada, a firma fechou antes de eu voltar da licença, ai já estava assustada com isso né e eu precisava trabalhar e também pelo medo, e já estava com esse problema e não sabia se eu ia continuar tomando remédio ou não porque já tinha aquele problema das manchas, eu já estava pra fazer biopsia pensando ser câncer de pele, porque era horrível, ficava aquelas manchas de quando formiga lhe morde e ai ficava aqueles caroços no rosto e peito. Ai resolvi, conversei com o médico e resolvi ligar por causa disso.

Pergunta 3: Você teve alguma informação sobre a ligadura de trompas? Por quem foi dada?

Não, durante a gravidez eu conversei muito com minha médica, sobre os problemas que enfrento e poderia vir a enfrentar com outra nova gravidez, e tudo ela disse: Se você acha que vai enfrentar tudo isso, então você já está decidida e já conversou com ele (o marido) e tudo, ele também não foi contra, ai eu disse não, eu vou ligar. 
Pergunta: Foi falado de outros métodos?

Não.

Pergunta: Você foi ao planejamento?

Não. A médica viu que não tinha alternativa prá mim. E ela disse: desde quando você está se achando sem alternativa, prá vir da num problema maior então já que você está se decidindo a isso né? Então você liga. Já que está fazendo o acompanhamento certinho do pré-natal, ai foi fazendo as ultras, todos os exames que ela vinha pedindo, foram todos feitos agora eu estou tranquila. De um filho para o outro foram quase 12 anos tomando anticoncepcional, foi quando veio aparecer esse problema. Agora o problema apareceu e eu fiquei quase 3 anos com esse problema tentando descobrir o que foi e nada de médico nenhum descobrir. E olha que eu tirava ultra e ia fazer preventivo, sempre que sentia uma dorzinha enjoada me passava os remédios e tudo, nos preventivos só dava aquela inflamaçãozinha normal, e ninguém nunca me disse que era um problema desse e os dermatologistas fazia vários tipos de testes, gastei o que não tinha que fui até um médico particular, e ninguém descobriu esses caroços no rosto e quando eu saia ao sol era que aumentava as placas.

Uma médica falou, porque você não para os remédios e faz o DIU prá ver porque já tenho trocado vários remédios. Mas eu já estava no pensamento de parar o remédio, e quando engravidei resolvi ligar.

\section{Entrevista 5}

Pergunta 1: Como você fazia para evitar filhos desde o começo de sua vida sexual?

Sempre usei pílulas, ai comecei a usar aquele Microvilar, ai fiquei muito mal, comecei a emagrecer, perder o apetite ai passei a usar Nordete não senti bem também ai passei para Neovilar e tomei até antes de ligar. Tomando ele, resolvi parar não estava sentindo bem e ai conversei com meu esposo, que achava melhor ligar. Sempre usei por minha cabeça mesmo. Os três partos foram cesariana, a mais velha está com 7 anos a menor está com dois e esse agora que eu liguei. Quando sentia que estava meio fraco o remédio eu ia trocando por minha cabeça mesmo sem indicação médica sem nada.

Pergunta 2: Como você decidiu fazer a ligadura de trompas?

Por que com três partos cesariano né eu não ia tentar um quarto que é mais perigoso, ai conversei com meu esposo, fiz os papéis com o rapaz ai, com Tarcíso, um dia levei na casa de Lúcia, a moça que é tipo fiscal aqui na rua entendeu. Ai conversei com ela que fiz os papéis e disse que quando eu tivesse perto de ter nenê ele fazia tudo junto.

Pergunta: Quem falou?

Tarcísio que encaminhou, o médico, prá eu ligar, no Hospital da Mulher. Tava tudo certo para mim ligar em São Gonçalo ai, so que fiz 9 meses no dia 23 e no dia 22 deu a dor, ai não deu tempo de ir prá São Gonçalo, porque eu ia terça- feira quando foi na Segunda deu a dor e não deu tempo ir e liguei no Hospital da Mulher mesmo. Fui na casa de Saúde e não tinha médico, e eu fui pró hospital da Mulher. O médico conversou lá e disse que ia ligar lá mesmo, não precisava viajar para ligar não. Eu ia ligar em São Gonçalo, mais a dor deu antes de Terça- feira que ia e liguei aqui mesmo, não precisou viajar.

Pergunta 3: Você teve alguma informação sobre a ligadura de trompas? Por quem foi dada? 
Conversei com minha mãe, disse a ela que eu ia ligar, não ia esperar para Ter mais filho não, e ficar tomando comprimido eu não ia querer mais nem botar DIU, queria ligar mesmo. Você freqüentava o Planejamento? Não . Na hora da cesariana mesmo eu falei que queria ligar, "quero estrangular" eu até falei com o médico na hora eu quero estrangular, ele até não gostou. Disse que o médico era ele e que era pra não ficar perguntando nada não se ligou não. Eu falei que queria estrangular, ai ele disse que o médico ali era ele pra não ficar perguntando nada não, (risos) acho que na hora do nervoso o médico com tanta cesariana pra fazer, tanto parto, um em cima do outro, acho que a pessoa fica até... ele me respondeu um pouquinho mal mas nem liguei, eu sei que era o nervoso mesmo, naquele sufoco todo. Mas eu tenho minhas dúvidas ainda se ele estrangulou viu, ele não me mostrou nada, não mostrou a maioria do povo diz que mostra né as trompas. Aí eu perguntei a menina que estava do lado ela disse que estrangulou, agora se estrangulou eu não sei. Se eu voltar a ter outro filho o negócio vai pegar viu?

Era pra ficar só com dois filhos, o último eu peguei com remédio, esse neovular, a menstruação estava vindo antes de acabar o comprimido, ainda tendo 10 ou 11 a menstruação estava vindo. Ai eu senti eu não estava mais me dando com o comprimido né? Quando fica assim é que não estava dando mais. Aí conversei com meu esposo que era melhor ligar mesmo. Por que nunca vi eu tomando comprimido e a menstruação descendo. Também não estava sentindo bem, sentia falta de ar.

P. você conversou com algum médico sobre esse mal estar?

Não, tomei a decisão e quis ligar, o médico que fez meu parto na hora perguntou quantos filhos eu tinha. Eu disse que tinha três cesarianas e não queria filho mais não. Já pensou 03 filha cesárea. Ele me perguntou se eu não queria esperar o menino não, eu disse não! Quatro cesáreas é perigoso, eu não tenho condição de ter filho normal, a mais velha e a segunda estavam sentados precisava de cesariana mesmo e essa de 02 meses estava em posição normal, tudo normal, fez a cesárea prá poder ligar poderia até ser normal, mas eu ia ligar por que é um resguardo só, não precisa voltar ao hospital e cortar de novo, fez um trabalho só. Foi até muita sorte minha porque aqui em Feira não deixa ligar assim. Acho que foi porque já tinha feito os papéis, tava tudo pronto já, faltava só o doutor assinar e ai lá mesmo ele assinou.

\section{Entrevista 6}

Pergunta 1: Como você fazia para evitar filhos desde o começo de sua vida sexual?

$\mathrm{Na}$ verdade eu pouco fiz, antes de engravidar do primeiro menino eu nunca tomei nada, eu tive ela e fiquei amamentando, amamentei ela um ano e oito meses, até 11 meses eu nunca menstruei, aí fiquei com medo e fui ao médico e ele passou um remédio e disse que mesmo amamentando eu ia menstruar, ai eu comecei a tomar o remédio, aí a menstruação apareceu depois e eu parei, com ele com um ano e 11 meses eu tive problema de garganta e tive que tirar a mama dela, nesse período, acho uns 02 meses depois eu engravidei do menino. Do menino foi a mesma coisa, eu passei mais ou menos 01 ano e meio sem menstruar amamentando.... depois comecei a tomar remédio de novo quando parei, eu tomava a "femina" ai comecei a sentir mal pressão baixa, ai o medico mandou parar um pouco, e fiquei usando camisinha, acho que nesse usar de camisinha deve ter falhado nasceu Gabriele.

P. Você frequentava o planejamento familiar?

Não, eu fui no médico e ele passou mas nunca freqüentei o planejamento familiar não. 
Pergunta 2: Como você decidiu fazer a ligadura de trompas?

A ligadura eu decidi por que desde que eu tive a primeira menina a médica disse que eu não tinha condições, de ter parto normal porque tinha o colo muito fechado, ela ainda avisou: "olha mãe se você tiver dois ou três vai ser tudo cesariana" Ai também eu tenho sangue negativo e já fiquei com medo, eu tive o menino agora tive de fazer uma bateria de exames e graças a Deus está tudo bem. Decidi também por que três cesarianas, depois de três ninguém tem condições de fazer mais uma cesariana. E tudo isso, a vida está tão difícil, prá três filhos. Quando eu engravidei dela eu parei de trabalhar por que eu trabalhava autônoma vendendo cosméticos, parei de trabalhar ficou só o dinheiro do marido, fica difícil. Ai eu decidi ligar, a médica pediu pra fazer a entrevista com a assistente social. Desde que eu tive o menino (2) que eu já ia ligar, cheguei a marcar prá fazer particular, mas só que o médico, viajou, e quando comecei a sentir as dores vim prá aqui, tive aqui, também na época eu estava muito nova, agora eu acho que ainda estou nova, prá ligar mas a médica optou porque não tenho mais condições de ter mais outro e prá não correr o risco, ela achou melhor ligar. Na hora que ela estava fazendo o parto ela disse se fosse eu que tivesse feito o seu segundo parto já tinha ligado, seu útero não tem mais condição de ter outra cesárea.

Pergunta 3: Você teve alguma informação sobre a ligadura de trompas? Por quem foi dada?

Tive, desde que eu tive o menino o médico me falou, aquele doutor..... que é do CEPAR, ele falou olha mãe, prá ligar devido ao seu problema de não ter normal, pode ser só que você está muito nova, e se você ligar agora corre de mais tarde você ter problema de hemorragia, e outras coisas então é melhor você espere mais um pouco para chegar aos 29 anos ou 30 pra ligar, já que não deu certo agora eu liguei.

P. Ele lhe sugeriu algum outro método?

Ele sugeriu assim, ir evitando, tomar o remédio mesmo, usar a camisinha, mas no meu caso não comecei a passar bem com as pílulas, passei um período usando alternativos essas coisas. A Dra . Ana falou a mesma coisa, e aqui também a Dr. Eugênio chegou a me falar: "Se você quer ligar, ligue mas eu esperaria mais um tempo" mas pra quem já estava com a cesariana, pra mais tarde ter que cortar tudo de novo eu achei melhor ligar logo tudo junto. Aí combinamos, o meu marido estava viajando, e esperamos ele chegar. Fomos lá no serviço social, fez a entrevista lá com ele.

A decisão não foi só pelo parto cesáreo, por que já sabia desde o primeiro que eu não podia ter muitos, o máximo estourado era três mas também as condições de vida, por que acho assim prá você colocar um filho no mundo você tem que dar tudo que ele precisa né? Uma escola boa, boa educação, alimentação, tudo. Graças a Deus não falta nada, mas a gente quer sempre dar o melhor aos filhos, e pra depender só de dinheiro do marido... por um bom tempo eu não vou trabalhar. Já tem a menina que estuda, em escola que é particular, esse ano também já vai o outro para escola particular também, fica um pouco pesado.

\section{P. Alguém lhe falou do DIU.}

Falaram, em quando tive a menina, ( $2^{\circ}$ filho), quiseram colocar o DIU, só que depois que tive a menina, sentir tanta dor, me senti tão mal que eu fiquei com medo, mais uma dor, não quero não e já colocava no outro dia mesmo, aí não quis, ai depois tinha que ir para o planejamento familiar eu fui relaxando e passou. Mas já estava decidido se a médica não ligar eu vou colocar o DIU. Depois a gente viu o meu marido disse que ia fazer a vasectomia, mas aquela coisa de homem sabe como é não é? Do menino ( $2^{\circ}$ parto) disse assim se você vai não tiver condições de ligar, se o médico não ligar, eu faço a vasectomia. Foi no médico fez os exames marcou, só que foi na época do carnaval em salvador o Doutor viajou e disse que na volta fazia, chegou, veio o micareta, foi passando, passando e olha a Gabriele aí (risos). 


\section{Entrevista 7}

Pergunta 1: Como você fazia para evitar filhos desde o começo de sua vida sexual?

Eu tive o primeiro com 17 anos e o neném morreu, e depois eu comecei a tomar o anticoncepcional, depois eu parei e veio a menina que agora tem 11 anos, e durante esses onze anos eu parava dois meses e ai voltava de novo, a tomar o anticoncepcional e ai depois de onze anos eu parei dois meses e ai veio o menino, nesse período alternava a pílula com o coito interrompido aí durante o pré-natal dele eu conversei com a medica e resolvi ligar. A médica me explicou, perguntou se eu queria isso mesmo falei que queria isso mesmo eu falei que queria ai eu liguei.

Pergunta 2: Como você decidiu fazer a ligadura de trompas?

Porque não queria mais filho, sei lá por causa das condições também, não é? Com muito filho não dá, também as condições hoje são muito precária. Conversei com meu marido e ele concordou, aí a médica disse que ia ligar. Desde quatro meses que o menino estava sentado, e a médica falou que se eu quisesse ou não tinha que fazer cesáreo e aí aproveitou mesmo que ia ser cesáreo e liguei, mas foi uma decisão minha mesmo. Eu não queria mais filho mesmo, o sofrimento é muito grande.

Pergunta 3: Você teve alguma informação sobre a ligadura de trompas? Por quem foi dada? Conversei com algumas pessoas, umas davam conselho prá fazer, outros dizia prá não fazer eu tenho uma vizinha lá mesmo que fez e ela mesmo falou pra mim "não sente nada não... faz mesmo, tu já vai fazer a cesárea mesmo, aproveita e faz", a médica disse prá eu pensar bem prá não me arrepender, prá conversar com meu marido. Mas ele aceitou tudo e a médica me explicou tudo também disse que depois de ligar não tem mais condições de ter filho. Ai ela conversou comigo, eu vim no pré natal umas 7 vezes toda vez que eu vinha ela falava e perguntava se era isso mesmo que eu queria, que eu só tinha um filho que esse era o segundo e eu sempre dizia que era isso mesmo. Acho que ela estava meio assim sem querer fazer. Mesmo tendo usado pílula 11 anos eu queria ter certeza que não ia engravidar mesmo. Só ligada que eu tinha certeza. Há muito tempo atrás, eu fui ao planejamento familiar uma vez no posto, assisti uma palestra, era para colocar o DIU, mas eu desisti e não voltei mais. Fui ao ginecologista e ele passou o anticoncepcional e eu usei e depois quis ligar.

\section{Entrevista 8}

Pergunta 1: Como você fazia para evitar filhos desde o começo de sua vida sexual?

Eu nunca tomei remédio, eu tive a primeira menina, e tem muita confusão com meus pais. $O$ pai da menina não assumiu ela ai meu pai ficou com raiva, porque ele teve que assumir eu e ela, e eu não trabalho não. Ai depois eu fiquei andando no centro de tanta confusão no meu juízo e não queria vim prá casa. Fiquei no centro. Ai eu fiquei no Centro de Abastecimento. Teve uma colega minha que me deu a casa dela prá eu ficar mais eu não quis.Voltei prá o Centro de novo dormia lá. Ai apareci de barriga dessa menina (que tem 4 meses). Ai foi a mesma coisa, só que eu botei o pai dela lá onde tira carteira de trabalho, a $\mathrm{Sr}^{\mathrm{a}}$. Sabe onde é? (SAC) e até hoje esta resolvendo esse problema. Porque ele é casado me enganou dizendo que não era, depois quando eu estava morando com ele a mulher dele apareceu e tem um bocado de filho. Ai eu perguntei a ele porque você me enganou dizendo que não tinha 
mulher. Depois que eu apareci de barriga ele me botou prá dormir no centro, ai me batia, a mulher dele me batia, os filhos dele, todo mundo. Ai meu pai disse: Se tu aparecer de barriga eu não te quero aqui. Ai eu botei aquilo na cabeça e fiquei lá. Eu já estava dessa finura (mostra o dedo). Ai meu pai soube e achando que eu ia morrer, me trouxe prá dentro de casa de novo. Ai aqui já em casa eu tive ela. Ai minha mãe acertou a ligação prá mim. Ai no dia da ligação eu fiquei com medo. Todo mundo diz que dá mioma, que dá problema na cabeça no lugar que liga, ai eu fiquei com medo ai eu falei não vou ligar, não vou, não vou.

Ai minha mãe falou se tu não ligar tu pega a menina e vai pró meio da rua, e eu disse: vou prá rua mais não vou ligar. Ai ela falou assim, é bom prá tu, porque tu pode trabalhar e não vai parir mais. Ai eu pensei ela quer isso prá mim porque sabe que não me quer parindo mais. Porque mãe é mãe. (Só que essa mulher que eu moro não é minha mãe, é mãe de criação) e faz mais coisa prá mim que meu pai. Ela acerta tudo prá mim. Depois que eu tive a menina dos remédios que ele (o pai da criança) me deu prá perder ela, e fiquei toda inchada ai voltei prá casa de Saúde de novo porque tive ela na casa de Saúde. Ai chegou lá disse que o "parto que virou água" ai tomei remédio e depois liguei.

\section{Pergunta 2: Como você decidiu fazer a ligadura de trompas?}

A minha mãe acertou, e eu liguei. Lá na Casa de Saúde mesmo, com Dr. Tarcísio. Ai depois que eu vi um bocado de mulher indo ai eu não fiquei com medo não.

\section{Pergunta 3: Você teve alguma informação sobre a ligadura de trompas? Por quem foi dada?}

Não perguntei nada, ninguém falou nada ai eu liguei, não senti nada, só uma dor de cabeça porque fiquei muito nervosa, eu tomei muito soro, porque eu estava de anemia profunda, ai tomei muito soro e ficava chamando as médicas, as enfermeiras prá tirar o soro e elas não tiraram eu mesmo tirei, porque estava saindo sangue da veia, eu fiquei nervosa e queria vir embora no mesmo dia. Ai elas diziam "mãe"- você tem que ter paciência, foi só isso.

Depois que eu tive a primeira filha minha mãe queria botar o DIU, só que minha mãe depois ficou com medo de botar o DIU e sair do lugar, e dá problema no meu útero. Depois do $2^{\circ}$ parto ela acertou a ligação porque ligada não tem problema nenhum ai eu liguei.

\section{Entrevista 9}

\section{Pergunta 1: Como você fazia para evitar filhos desde o começo de sua vida sexual?}

De primeiro eu não usava nada, o difícil era engravidar, depois eu casei com 16 anos, logo engravidei do primeiro. Ai eu usei o DIU por 05 anos, aí o DIU ficou fora, ai minha famńlia mandou botar de novo, ai eu não pude colocar por que eu estava perdendo muito sangue, ai engravidei do segundo filho, mas perdi, ai o médico do hospital pediu para não engravidar logo. E a pílula eu não posso tomar por que tomo gardenal, ai engravidei do nenêm que está agora com 01 mês.

Pergunta 2: Como você decidiu fazer a ligadura de trompas?

Por que o médico do pré-natal disse que eu já devia ter ligado que eu não podia ficar engravidando não por causa dos meus problemas ai minha irmã conversou com $\mathrm{Dr}^{\mathrm{a}}$. Joana e ela disse que me ligava. Que é melhor ligar do que fica parindo todo ano. Ai eu fiz o parto no Dom Pedro e ligou, fez cesária e ligou. A minha família que mandou e eu não podia falar nada, fiquei quieta. O meu marido aceitou. Eu só pensei que o meu problema ia piorar ligada. 
Pergunta 3: Você teve alguma informação sobre a ligadura de trompas? Por quem foi dada?

Quem conversou comigo foi a médica Dr ${ }^{\mathbf{a}}$. Elizabete, ela disse que se eu ligasse nova demais mais tarde poderia ter problemas $\mathrm{Dr}^{2}$. Elizabete disse que eu só podia ligar com 30 anos, que cu podia usar o DIU de novo, ai minha família me botou pra ligar e eu não podia fazer nada, fiquei quieta. Foi mina mãe e minha irmã. Ai depois da ligação eu sinto dor por dentro. Hoje está com 01 mês e doze dias. Depois não tive mais problemas e não desmaiei nada. Só fui no planejamento familiar para botar o DIU e não fui mais.

Só que eu não sinto nada (prazer) acho que é por causa do gardenal. Eu tomo desde pequena tem gente que toma e para eu não.

\section{Entrevista 10}

Pergunta 1: Como você fazia para evitar filhos desde o começo de sua vida sexual?

Eu tomava comprimido desde o primeiro, mas eu não sei se era a luta do dia-a-dia que eu errava o horário ou o dia, ás vezes acontecia de não ter tomado e tinha relações crente que tomava mas não tinha certeza com a luta do dia-a-dia às vezes a gente se esquece, aí aparecia grávida sem querer. Ai engravidei de cinco filhos, mesmo tomando pílula. Ninguém acreditava, diziam ah, evitando tomando pílula ninguém engravida agora eu voltava c dizia a mim mesmo o erro deve ser esse eu esqueço e penso que tomei e não tomei. Mas nunca me faltou o comprimido. Teve uma época que cu freqüentei o planejamento, no posto, mas como tinha menino pequeno era difícil de ir eu passei a comprar o remédio. Ofereceram pra mim o DIU mas eu tinha cisma, sei lá sinto que tenho uma aparelho diferente dentro de mim, e nunca usei não, camisinha nunca usei, tentei a injeção de 01 mês, mas eu menstruava duas no mês, ai tentei com a de 06 meses, custava até 20 e poucos reais, ainda tomei umas 03, mas menstruava no primeiro mês, ai voltei a tomar comprimido ai foi que decidi ligar.

Pergunta 2: Como você decidiu fazer a ligadura de trompas?

$\mathrm{Ah}$ ! Eu tinha muito medo de ligar por que eu nunca fiz uma cirurgia e tinha muito medo da anestesia, ai eu ainda marquei com o político em 92 , do $2^{\circ}$ menino. Ai quando o carro me pegou aqui prá levar pra São Gonçalo eu fiquei com medo, não fui. Só que agora me apeguei muito com Deus, ai fui e graças a Deus...

Ah eu pensei que eu tinha muitos filhos e eu não tinha condições de criar mais de cinco e já estava na idade avançada prá eu ainda ter mais filhos. Eu tenho três filhos indesejados, eu não planejei. O primeiro eu tive com 22 anos, e fiquei 05 anos tomando comprimido. Depois não deu mais esse espaço. Fui orientada pelo médico como tomar tudo, mas a luta do dia-adia esquecia.

Pergunta 3: Você tem alguma informação sobre a ligadura de trompas? Por quem foi dada?

Não, não tinha orientação de ninguém. Eu estava fazendo os exames no Hospital da Mulher, mas suspenderam as ligaduras no Hospital da Mulher ai eu consegui em São Gonçalo por que em São Gonçalo tem uma menina aqui que marca, guia a gente para ligar em São Gonçalo, uma moça não sei se é médico mas ela passa os exames para a gente fazer e marcar ai a gente pega o carro na Casa de Saúde Santana e vai prá São Gonçalo. Não tive orientação de ninguém, em via as outras fazendo e não paria e eu também queria parar de parir, também as pessoas diziam Ah! Hoje em dia pare por que quer, tem ligadura tem como evitar tem tudo, a gente fica parindo fica até com vergonha. Mas dizem assim "existe remédio pare por que quer, eu não tenho pena de ver uma mãe cheia de filho" ai a gente se sente humilhada, é uma humilhação, mas tem muita gente que diz, só gente entendida que não diz. Mas as 
pessoas falam assim. Ai eu resolvi por que já tinha muito filho e já tinha chegado a idade. $O$ DIU eu tinha cisma, já vi como era no planejamento, um negócio assim pra ficar dentro sei lá, as injeções foi o problema que descia antes da data e o comprimido eu engravidava tomando. Hoje mesmo eu joguei umas 04 cartelas vazias fora, eu guardava pra mostrar pro médico como eu evitava e engravidei. Eu queria provar que eu tomava mas ninguém acreditava que eu tomava (lágrimas). Mas eu tinha muito medo da cirurgia e anestesia tinha medo de morrer ou ficar aleijada. Tem horas que fico pensando que nem liguei por que a coragem eu digo que foi Deus que me preparou para não ficar nessa preocupação por que já com cinco filhos e sem condições boas. Por que tem horas que falta...

\section{Entrevista 11}

Pergunta 1:Como você fazia para evitar filhos desde o começo de sua vida sexual?

Eu comecei minha vida sexual eu tinha 14 anos. Foi meu $2^{\circ}$ namorado, ai quando ele quis noivar a família não deixou por que a gente era muito novo, eu tinha 14 e ele 18 ai aconteceu a gente fugiu e lá eu fiquei grávida, minha filha tem 17 anos, quando ela nasceu eu comecei a tomar comprimido, eu evitei 03 anos, aí veio a $2^{\mathrm{a}}$ que tem 14 anos passei mais três anos evitando ai veio a de 11 anos, evitei mais quatro anos e meio, o menino que tem 06 anos veio e continuei com a pílula, aí depois de 06 anos e continuei a pílula, ai depois de 06 anos veio esse nasceu está com 04 meses, ai eu resolvi ligar por que já estava com 05 filhos. Nunca senti nada com a pílula, nunca senti problema nenhum. Fazia meus exames, o preventivo tudo normal.

Pergunta 2: Como você decidiu fazer a ligadura de trompas?

Resolvi ligar por que já tinha 05 filhos, trinta e três anos já estava me achando coroa pra estar na maternidade parindo, aí cheguei a isso. E tive 03 partos complicados o outro eu quase morro, porque o bebê estava sentado e eu fiz pré-natal direitinho, e a médica não me disse que ele estava sentado, quando passou 11 dias dos 09 meses ( ele nasceu em Alagoas) eu tive uma briga com meu marido umas 05 horas da tarde quando foi umas 09 horas, véspera de natal; fui tomar um café por que eu fumo, fui levantar quando fiz força eu senti um estalo e a barriga desceu, e eu comecei a água umas 10:30h fui para o hospital, a enfermeira me examinou disse que estava tudo bem e só por aquela aguinha eu não ia perder meu bebê, e me mandou prá casa, e eu confiei nela. Não sentia nada, fui prá casa quando deu meia noite comecei a sentir dor uma em cima da outra, eu não podia nada no outro dia, não quis ir pro hospital antes da moça que ia olhar os meninos chegar. Quando fui tomar banho as mãos estavam roxas e o corpo todo manchado. Ai senti que estava saindo as fezes do nenên, aquela que faz depois que nasce de tanto está judiando dele. Ai fiquei nervosa. Quando cheguei no Hospital tudo que lembro é que entrei na sala de parto e pedi socorro ao médico. Ele pediu prá me preparar para o cesário, quando as enfermeiras me examinou disse ao Doutor que não tinha mais condições de fazer cesário, o bebê estava com metade do bumbum de fora. Ai eu não ouvi mais nada, e não enxergava mais nada. Só acordei meio dia, toda amarrada e no balão. Ai o médico tirou o balão. Ai o médico disse que depois conversava comigo. Ai mais tarde a enfermeira me disse que o meu parto não tinha sido normal tinha sido puxado a ferro. Mais tarde o médico veio e ai falou que eu não podia mais ter filho, e me explicou que eu tinha tido eclampsia e se eu tentasse engravidar de novo, se não perdesse o bebê no começo da gravidez, eu não chegaria aos 7 e se chegasse eu teria crises e quando o bebê nascesse ia nascer com problema aquilo deu muito medo. Ele disse que eu poderia voltar com 90 dias e agente faria os exames e ajeitava e disse eu ligo você e você não me paga nada. Só que quando fez 90 dias eu fiquei com medo do bebê morrer e ficar sempre com aquele sonho, e se eu ficasse como eu estava, tinha chance de fazer um tratamento e ter outro filho, ai sim eu poderia ligar e assim fiz, vim embora e quando o 
menino fez 06 anos eu engravidei e graças à Deus não sentì nada, mas ele era sentado e colado como o irmão, só que eu fui mais sabida fiz pré-natal direitinho e conversei com minha tia que é enfermeira do Dom Pedro ele conversou com o médico, Dr. Eugênio e ele fez a cesárea e ligou.

Pergunta 3: Você teve alguma informação sobre a ligadura de trompas? Por quem foi dada?

A decisão foi por conta de tudo isso. Mas o médico disse a minha tia. Vai depender muito de Ter alguma coisa que impeça. Por que se não for assim eu não vou ligar uma coisa sem necessidade; no $8^{\circ}$ mês eu fiz ultrasom e levei prá ele, aí eu disse que tinha muito medo, mas ele falou que o parto não podia ser normal que o bebê estava sentado e que eu poderia ter outros filhos mas que correria o risco de Ter problemas. Eu tive muita dor de cabeça na gravidez, não dormia direito ficava nervosa com tudo. Tinha que sair para conversar com alguém. Pensei que já tinha 05 filhos e não valia mais a pena engravidar. E hoje em dia está tão difícil da conta de 05 filhos pra dar estudo pra dar de tudo. Pensei, acho que não estou pecando não por que eu vou ligar não.

Nunca fui ao planejamento. Conhecia outros métodos mas confiava mais no comprimido por que nunca senti nada. Quando comecei a tomar fui à médica e disse a ela que fumava e ela me disse faz mal que cigarro com esse tipo de remédio, só que eu nunca dei ouvidos e fumava e nunca tive nada, na gravidez da complicação eu tive pressão alta. Também sofri muito na gravidez do meu filho. Eu vivi sete anos com meu marido, ele só pra mim, depois as coisas mudaram, ele começou a arrumar coisa fora, eu fiquei sabendo, foi na época da gravidez, até que com uma ele ficou firme e tanto é que ele tem um filho, o meu tem 06 anos e o dele tem cinco, eu ficava sem comer só fumando e esperando por ele pra brigar.

\section{Entrevista 12}

Pergunta 1: Como você fazia para evitar filhos desde o começo de sua vida sexual?

Eu sempre usei remédio de evitar, o microvilar ai comecei sentir enjoou, querendo vomitar ai depois eu suspendi, por que o médico disse que minha pressão estava subindo muito, aí ele perguntou: Por que não bota o DIU ? Ai eu fiz todos os exames e botei o DIU, depois de cerca de três meses, eu comecei a sentir também a menstruação vinha e saia os bolos, ai eu voltei ao ginecologista de novo e ele disse que eu não poderia usar o DIU, que estava inchando o meu útero, ai eu peguei e tirei o DIU, ai levei três meses usando camisinha ai eu vi que não dava certo, ai eu fui e fiz o tratamento e liguei. Só tenho um filho, tive um e um aborto, depois do aborto que eu liguei. Meu tem seis anos, depois que eu tive ele, eu comecei a tomar o anticoncepcional, depois que eu tive ele, comecei a tomar o anticoncepcional, durante dois anos, antes de parir eu não usei nada, por que assim que tive relações eu engravidei logo. O DIU só usei seis meses. Depois usei camisinha, depois entrou uma equipe ai dizendo que ia operar e disse que eu poderia ligar por que já tinha idade ( 27 anos) ai peguei e liguei.

\section{Pergunta 2: Como você decidiu fazer a ligadura de trompas?}

Eu pensei em ligar de várias formas, por que quando entrei logo para o PACS, disseram: Ah! Se engravidar você perde o emprego. Ai eu fiquei com medo, porque era recente e o que eu mais queria era esse trabalho ai eu falei assim: o jeito é eu ligar, ai falei vou ligar, ai o pessoal veio, e falou se você quiser ir, você vai ligar, ai eu encaminhei os exames e fiz a ligadura. Fui, viajei e me liguei lá em São Gonçalo. Minha preocupação era não perder o emprego ai eu peguei logo e liguei. Eu tinha medo de perder emprego. Eu queria muito esse 
trabalho porque eu lutei tanto pra ter ele e perder assim através de um filho, eu peguei e liguei.

Pergunta 3: Você teve alguma informação sobre a ligadura de trompas? Por quem foi dada?

Não, ninguém conversou não, sempre os colegas falavam né. E o doutor quando foi me ligar falou: "você tem 50\% de pegar cisto no ovário", ai eu falei assim... " Cisto no ovário e ter menstruação demais, eu falei não tem nada não, mas é normal ? Ele falou que era normal ter antes da ligadura ele falou e entrou de quarto em quarto, e disse que poderia ter cisto no ovário e ter menstruação, a menstruação correr demais, ainda ele perguntou quantos dias eu ficava menstruada e eu disse que durava três, quatro dias e ele falou: agora vai ser normal você ter 7 a 8 dias de menstruação. Ai eu falei então está certo. Ai eu peguei me liguei. Mas ele foi de quarto em quarto Dr..... Ele não falou de arrependimento, só falou se agente queria mesmo ligar, se era aquilo que a gente queria. Eu falei que era, e as meninas todas que foram comigo falou também que era que a gente queria era isso mesmo. Ai ele pegou c fez a ligadura. Ao planejamento familiar eu fui quando usava anticoncepcional, eu fazia no posto de saúde, eu pegava o comprimido, e quando não tinha eles davam um, pra substituir o microvilar, foi quando cu comecei a sentir mal foi ai, por que começou a variar, e dizer que faz mesmo efeito, não sedava bem de jeito nenhum, ai eu que não tinha condições de comprar. Eu sabia todos os métodos lá no planejamento. Tentei a pílula, tentei DIU, a camisinha e partir pra ligar, mas só me liguei, mas só me liguei por causa disso, e fui com medo viu? Eu fui com bastante medo, tinha medo de morrer! Eu tinha medo de morrer, meu Deus do Céu, por que o pessoal me metia medo também, que muitas morriam, que a anestesia "raque" se não tomasse cuidado ia ficar paraplégica, eu ficava com medo, mas, eu fui (risos) mas ai eu fui mesmo! Hoje eu não sinto nada graças a Deus não sinto nada. Só sinto mesmo, que eu não sentia é cólica. Eu não sentia cólica de jeito nenhum, minha menstruação ia vinha e eu nem sabia. Hoje quando está perto de vir, 03 dias antes é uma cólica... e quando está perto de ir embora também é uma cólica muita cólica mesmo, e minha menstruação redobrou, corre demais, corre demais mesmo, parece até que é hemorragia. Só isso que eu sinto. E depois que eu me liguei eu fiz um exame ginecológico e ele falou que isso é normal na mulher ligada que não era pra mim ficar com medo não que era normal, que com o tempo ia diminuindo por ela mesmo.

\section{Entrevista 13}

\section{Pergunta 1: Como você fazia para evitar filhos desde o começo de sua vida sexual?}

No começo eu usava tabela, depois comecei a usar anticoncepcional, mas começou a me dar dor no estômago, muita dor no estômago, inclusive o médico suspendeu e me falou para usar a camisinha pois já que tem dores é bom fazer um exame prá saber, e se é com todos os anticoncepcionais, porque algum anticoncepcional poderia não dar. Ai eu mudei para um outro que era importado, e tinha lá no posto. Eu não senti dor, mas optei por não mais usar, por que não gosto e também por problema de pele, eu já tenho uma pele ruim (manchas) e o anticoncepcional é uma maravilha para manchar a pele ai parei e fiquei com a tabelinha. Eu usei anticoncepcional por meio ano e sentia dor parecia ulcera. Ai parei e passei a usar tabelinha eu já tinha o meu filho, o de doze anos, antes dele eu não usava nada, fiquei grávida mesmo, namorando e fiquei. Coisa de menina. Fiquei grávida e me casei, fiquei com ele por coisa do filho, $\mathrm{c}$ não durou mais que um ano. Me separei e casei novamente quando meu filho já tinha dois anos. E só lá prá 96 quando meu outro filho tinha... Sim, durante o $1^{\circ}$ casamento eu tive um aborto, como eu não estava bem com meu marido eu não queria o filho. Pensei já estou com ele por causa do filho pra criar, ficar grávida agora não dar mesmo, ai tomei o citotec, e estava tomando remédio de verme antes mesmo de saber que estava grávida. Ai acabei abortando, fui parar no balão de oxigênio e fiz a curetagem, de pois 
disso eu passei a me cuidar mais a ter mais cuidado. Não engravidei mais, e fiquei usando tabelinha. Nunca tentei colocar DIU, ai quando o meu primeiro filho já tinha oito anos decidimos ter outro filho, por que meu segundo marido queria um filho. Só que quando meu filho estava com dois anos e pouco eu fiquei grávida no carnaval. Numa festinha de solteiros, só eu e meu marido ai eu não pensei duas vezes, resolvi ligar. Eu ia colocar o DIU, lá com Dr. Elsimar Coutinho, eu ouvi falar que lá colocava direitinho, mas eu demorei e tem que colocar mestruada, e eu mestruei no carnaval, no carnaval não dava para colocar e quando voltei, e logo depois fiquei fértil e engravidei. Ai lá se foi o DIU. Como eu tinha tido uma parto muito difícil, que ele quase morreu no parto por ter nascido muito grande engordado muito na barriga, nasceu todo laçado a médica quebrou a clavícula, ficou com trauma de parto, por muito tempo chorava de noite. Eu ai fiquei traumatizada de ter filho natural ai eu decidi que outro filho que eu tivesse eu ia fazer cesárea, nesse período eu pensei, já que eu vou fazer cesárea eu vou ligar.

Pergunta 2: Como você decidiu fazer a ligadura de trompas?

Foi assim que eu pensei. Eu só perguntei a algumas amigas que já tinham ligado como era todas disseram doi muito mas não falaram que estava arrependida, doi muito os pontos.

Como eu já tinha 3 filhos eu achei que eu poderia fazer, por que prá que mais de três filhos no mundo de hoje né? Por mais que você tenha uma situação financeira equilibrada já é difícil colocar três filhos na escola particular, dentista, médico, ainda mais quem não tem, eu não tenho situação tão equilibrada assim, eu faço da vida gato e sapato prá conseguir. Agora, com relação a ligadura eu acho que devia ter, existir, uma diálogo maior do médico e a paciente porque é uma decisão pra sempre né. Eu acho que o médico deveria assim antes de levar o paciente prá o soro, deveria sentar um pouco, conversar, perguntar...

Pergunta 3: Você teve alguma informação sobre a ligadura de trompas? De quem?

Não, eu vim fazer a cesárea e disse que ia fazer a cesárea e ligar também. O médico só me perguntou quantos filhos eu já tinha, que idade eu já tinha, e por que eu queria fazer eu disse que eu queria fazer por que já tinha 03 filhos, que eu achava que já era filho demais e que eu já tinha trinta e três anos, uma idade boa que não estou tão novinha assim, tá bom de ligar e que eu não quero mais de três filhos. Mas, continuo achando que é pouca informação à respeito da ligadura. Mas tem gente que liga com dois filhos e até com um não é? $\dot{E}$ perigoso, eu que tenho três depois que eu liguei deu tipo assim, quase um arrependimento, bateu assim um "pos parto não é"? fiquei olhando o nenêm tão bonitinho... mas tudo bem era isso que eu queria. Por que também sou muito froxa, não dá eu não posso ficar grávida, eu tenho medo de parto natural, eu tenho medo de parto cesárea, não gosto de ouvir o barulhinho de ferramentas do hospital. A maioria das pessoas que conheço que fizeram ligaduras, eu acho elas muito pouco esclarecidas, são donas de casa, pessoas assim de mais idade não são pessoas assim que poderiam conversar, elas só falavam assim a injeção da coluna dói muito, e depois dói demais, dói demais e nem sequer falam que pode arrepender de querer ter filhos. Ah! eu pensei depois porque meus filhos são tão gostosinhos e eu pensei será que não vou querer outro. Com a minha médica eu comentei o fato de querer fazer cesárea pelo problema que tive no parto, mas na época, no início do pré-natal, eu nem pensava que ia ligar, só no final mesmo quando fiquei certo que ia fazer cesárea foi que ficou definido é que eu decidi: Eu vou ligar. Se já vou abrir a barriga se já vou sofrer ali, com aquele negócio da injeção, então eu vou ligar por que também acaba essa história de controle, que eu não posso tomar comprimido, o DIU eu vou Ter que controlar, aquela coisa de exame de $06 \mathrm{~cm} 06$ meses. Ai decidi não quero mais de três filhos mesmos. 


\section{Entrevista 14}

Pergunta 1: Como você fazia para evitar filhos desde o começo de sua vida sexual?

Tomava remédio, sempre tomei, eu engravidava porque não tomava o remédio certo. $O$ primeiro filho tem 15 c outro tem 13, outro 6, outro 5 . Eu fiz tabela, também mas fazia errado também. Nunca fui ao planejamento familiar. O remédio eu comprava na farmácia não era passado por médico.

Pergunta 2: Como você decidiu fazer a ligadura de trompas?

A ligadura, eu decidi por que sei não ficar só parindo, parindo ai disseram que aqui no hospital da mulher ligava, que o doutor ligava. Ai a menina veio aqui comigo marcou, eu assinei e ai vim me internar, ai fizeram a cesárea e ligaram. O pré-natal eu fiz do menino, do primeiro eu fiz em Brasília que eu morava lá e desse eu fiz aqui no Posto de Saúde. Ai disseram que se fosse cesárea eu podia ligar e se fosse normal não, que eu não podia ligar na mesma hora.

Pergunta 3: Você teve alguma informação sobre a ligadura de trompas? De quem?

As colegas falavam que prá ligar tinha que fazer cesárea, que se não fizesse cesárea eles não ligavam, tinha que fazer outros exames prá poder ligar. Ninguém mais conversou. Ouvi falar em DIU, botar o DIU tem que está todo mês no hospital, tem gente que não se dá, aí eu não quis botar também. A ligadura eu acho mais seguro.

\section{Entrevista 15}

Pergunta 1: Como você fazia para evitar filhos desde o começo de sua vida sexual?

No começo eu tomei pilula durante três anos, depois do primeiro filho, o filho mais velho tem 09 anos, o outro 8 e o outro 7, depois do de sete anos eu coloquei o DIU. Com a pílula eu sentia enjoou e estava engordando demais. Ai botei o DIU, depois não me dei também tirei, eu estava sangrando demais no período que botei o DIU, foram quatro anos e quatro anos de sangramento ai resolvi tirar, ai demorou uns dois anos eu engravidei. Fui ao planejamento familiar do hospital. Eu conhecia todos os métodos.

Pergunta 2: Como você decidiu fazer a ligadura de trompas?

Através do médico, mas a decisão foi minha mesmo, porque pensei que ia ficar engravidando direto, prá que? Ai decidi falei com o médico e ele falou que estava certo, e ligou. Por que eu tenho quatro filhos e já estava demais né? E não me dei com a pílula e o DIU.

Pergunta 3: Você teve alguma informação sobre a ligadura de trompas? De quem?

Conversei com minha comadre que é "enfermeira" e com o próprio médico. Ele falou que se eu achava que queria ligar. Ai ele marcou. Só que ele marcou quatro vezes e eu fiquei com medo, só que depois... eu tinha medo da anestesia. Só que ele falou da próxima eu lhe pego quando foi desse aconteceu, eu fiz parto normal e depois liguei pelo umbigo. Minha comadre achou bom também, já que eu não estava me dando com o DIU e a pílula, ela achou que eu devia ligar. Ninguém falou de arrependimento. O médico disse que já que você quer ligar vamos ligar e me deu parabéns por que não senti nada, reagir bem. Todas minhas amigas que 
já tinha feito me incentivou, eu só tinha medo da anestesia eu tinha medo de ficar alejada todos os meus partos foram normais. Mas não tive nada, estou aqui graça a deus. Fiz prénatal com o médico, eu conversei com ele e ele disse já que você quer ligar vamos. O que me levou a ligar mesmos foi a quantidade de filhos e os métodos que não deram certo.

\section{Entrevista 16}

Pergunta 1: Como você fazia para evitar filhos desde o começo de sua vida sexual?

Eu tomava remédio, mas não me dava e ai tomava dia sim dia não, até quando engravidei da primeira filha. Tomava hoje amanhã não tomava por que vomitava, enjoava, com dor de cabeça e sentia mal, parecendo que ia desmaiar, ai fazia assim um dia tomava e outro não, ficava tomando assim achando que evitava filho, quando engravidei da primeira e ai depois, com a Segunda foi a mesma coisa ai engravidei de Segunda e disse: dessa daqui agora vou ter que ligar, por que já tem dois com ele (marido) e mais dois só dele, inteirava quatro, e as condições de vida, a educação do fillho é coisa muito difícil pra poder criar os filhos, então foi desse jeito que eu arrumei um jeito de ligar logo, pagar prá poder ligar. Nunca fui ao planejamento familiar tomava remédio por minha cabeça, não tive orientação de ninguém. Eu sabia de outros métodos e não gostava e não gostava. Camisinha eu não quis, Diu eu tenho medo. Eu ia prá o médico fazia o meu preventivo tudo ok., o médico trocava sempre pra ver se eu me dava, eu tomava um mês não me dava o mais que eu tomei foi três meses pra vê se me dava. Tinha enjoou pior que a gravidez ai resolvi que já tinha dois com mais dois quatro ai resolvi logo.

Pergunta 2: Como você decidiu fazer a ligadura de trompas?

Foi pelo número de filho, que a situação está difícil e a educação em primeiro lugar, e a vida hoje tá que tá, a gente tenta educar e os filhos já quer ser dono de si próprio, não quer seguir mais os pais e dá muito trabalho, já tenho quatro filhos. Ai fiz cesárea pela SUS, e paguei prá ligar.

Pergunta 3: Você teve alguma informação sobre a ligadura de trompas? De quem?

Acertei tudo na hora, por que ele já tinha feito o meu primeiro parto, aí procurei ele antes e não falei de cesárea falei com ele que eu queria que ele fizesse meu parto de novo, aí ele chegou c pediu que ele o procurasse Quarta-feira, ai olhou meus exames direitinho e falou: " 4 a feira você me procura, por que de $4^{a}$ feira a criança não pode passar de nascer", tanto o médico da ultrasom como ele falou. Ai quando foi $3^{\mathrm{a}}$ à noite eu senti dor e Quarta eu fui. Ai ele fez a cesárea depois a gente conversou com ele que não tinha mais condições de ter filho, porque as condições de vida não dava. Ai ele cobrou 500 reais.

Eu pedi ao médico até pelo amor de Deus prá me ligar. Ai ele disse: seu marido já acertou tudo comigo. Também, já tinha duas cesárea e queria de qualquer jeito.

\section{Entrevista 17}

Pergunta 1: Como você fazia para evitar filhos desde o começo de sua vida sexual?

Nada, nunca fiz nada, nunca tomei nada, nunca evitei. O filho mais velho tem 17 anos, e todos foram partos normais. Nunca fui ao serviço de planejamento familiar. Nunca procurei. 
Fiz o pré-natal de todos, as pessoas falavam mas eu nunca liguei. Acho que por lerdeza demais, foi por lerdeza mesmo.

Pergunta 2: Como você decidiu fazer a ligadura de trompas?

Por que muito filho e as condições né? Ai eu decidi a querer ligar, por que evita com remédio podia falhar também, né? Aí eu falei o certo vai ser ligar mesmo. Nunca usei remédio mas achei que podia falhar e ligar é mais seguro. Eu sei de várias formas de evitar, a camisinha, o remédio, injeção né? Mas só que nunca usei nada.

Pergunta 3: Você teve alguma informação sobre a ligadura de trompas? De quem?

Conversei no hospital, antes não conversei com ninguém, não fiz pré-natal não, só na hora de parir é que decidi. Eu cheguei no hospital aí uma moça falou assim: Por que você não liga, você já tem filho demais, eu falei não vou ligar não, ai quando entrei que o médico foi fazer o toque eu falei assim: eu queria sair daqui ligada, ele falou assim: "com um mês a senhora volta, e eu disse eu não quero com um mês não, pode ser que eu não venha. Então ele disse quando a senhora sair daqui a senhora já sai ligada. Ai eu liguei. Decidi e fiz. Ninguém me falou nada, o médico disse que eu ia sair ligada e eu agradecia a ele e a Deus e pronto, e liguei. Eu penso que vai dar certo e que eu deveria ter feito isso antes por que ter 12 filhos não é brinquedo não, não é? Só tem vivo 08 , todos 12 foi parto normal, e os que morreu, morreram mais grandinho. Eu acho que não dei trabalho ao médico, não gritei, não reclamei; doeu porque acho a anestesia não pegou direito, então o que estava fazendo eu estava sentindo, mas eu não reclamei não falei nada. Mas foi culpa minha por que ele (o médico) falou que o que eu sentisse era para falar e eu não falei. Mas estou bem graças a Deus.

\section{Entrevista 18}

Pergunta 1: Como você fazia para evitar filhos desde o começo de sua vida sexual?

Tomava anticoncepcional desde o começo e ai comecei a tomar Nordete não me senti bem ai parei, comecei a tomar Microvilar, ai tomei direto e nunca senti nada. Fui ao Planejamento Familiar uma vez no posto, lá onde eu trabalhava também tinha sempre, tinha palestra ai eu achava melhor ligar porque não queria filho mesmo. Eu conhecia todos os métodos, da camisinha, injeção, DIU, isso tudo, mas eu achava melhor pra mim o remédio.

Pergunta 2: Como você decidiu fazer a ligadura de trompas?

Ah, porque eu trabalho, e não tem quem fique com o menino, minha mãe já fica com a menina, ai com mais esse agora, é muito trabalho pra ela, aí eu disse é melhor eu ligar por que não tem condições de estar pagando ninguém pra tomar conta, meu esposo trabalha autônomo, tem semana que ganha tem semana que não ganha. Ai eu pensei em ligar e ele estava de acordo eu fui e liguei. Só queria ligar. Porque dois filhos pra gente educar é mais fácil que três ou quatro, principalmente a gente que não tem muita condição, ter três, quatro filhos, pra não Ter o que dar, escola, roupa melhorzinha, e dois a gente tem condição e pode dar. $O$ único método que me dava certeza que eu não ia ter mais filho era ligar.

Pergunta 3: Você teve alguma informação sobre a ligadura de trompas? De quem?

Conversei lá na firma com a enfermeira e ela achou que eu estava certa dois filhos é mais que três quatro, pra quem não tem condições de criar dois filhos é melhor. Ela também falou no caso de um dia se eu quisesse mais filho, já sabe que não vai poder ter mais, eu disse sim 
eu já sei, mas é por que eu não quero ter filho mais. Mas eu não me arrependo não, eu queria ligar mesmo. Na minha opinião é assim, podia ser menino ou menina eu ligava do mesmo jeito, o que eu não queria era ter mais filho. Eu fiz quatro meses de pois de Ter menino, eu pensei em esperar mais, mas preferir ligar logo, porque, já pensou eu tomar remédio e falhar, porque eu tinha um medo, tinha dia que eu tomava remédio e ficava assim, será que eu tomei, será que eu não tomei, e tomava de novo, minha filha mais velha tem oito anos eu sempre tive medo, porque eu parei o remédio por um mês, e engravidei logo, aí eu fiquei com medo, e eu acho minha gravidez muito ruim, pois logo no começo da gravidez eu fíco sangrando, esse mesmo foi de oito meses. O primeiro filho que morreu foi de sete meses, se estivesse vivo estava com 12 anos. Eu tinha muito medo de parir a hora da dor, o medo de não parir logo de sofrer muito...

\section{Pergunta: Isso já aconteceu?}

Só do primeiro, eu demorei muito de ter menino, eu sofri muito, me colocaram um soro, eu pensei que ia morrer, eu gritava tanto, ... agora esse ai foi uma benção eu cheguei no hospital e pari logo do primeiro eu não tinha experiência, eu comecei a perder água a noite e não sabia, só urinando. Quando amanheceu o dia eu perguntei a mãe dele (do marido) e ela mandou eu ira para o médico, quando cheguei no médico a água tinha secado toda. Ai me colocaram no soro e eu sofri demais, demais, foi tanto que tive até problema respiratório. $\mathrm{E}$ também eu não gostei do atendimento, acho que lá eles maltratam muito as pessoas por isso tinha medo de ter filho por causa disso. Ai eu pensei não quero mais filho eu vou ligar. Ai eu fui e liguei. Conversei também com minhas colegas e elas disseram é mesmo dois filhos está bom demais. Todo me dava conselho pra ligar conversei com o médico e fui direto. Meu medo só foi na hora da anestesia mas não estou sentindo nada até agora, graças a Deus. Eu adorei ter ligado. Minha mãe é doente tem diabetes, tem pressão alta, e é muita coisa para ela. Eu vou deixar os meninos com ela até arranjar uma pessoa. Eu trabalho de duas às dez, quando chego às onze horas ainda vou pegar os meninos lá pra vir pra casa. A manhã eu fico com eles. Mas esse médico na minha vida foi uma benção.

\section{Entrevista 19}

Pergunta 1: Como você fazia para evitar filhos desde o começo de sua vida sexual?

Eu tomava pílula, ai eu tomei anticoncepcional e sempre parava quando a mestruação chegava, ai eu não sei se eu esquecia de tomar alguns comprimidos, só que era muito fértil, do terceiro menino eu fiz eletro e o médico Dr. Leone passou o "Diane" e com ele eu fiquei grávida tomando, isso ai eu tenho certeza absoluta, ai a médica, que já até faleceu ela proibiu eu tomar anticoncepcional porque sempre tive varizes e me incomoda muito, até hoje me incomoda, mas eu liguei porque sinto muita dor nas pernas e depois que tive o $3^{\circ}$ filho eu fiquei grávida da $4^{a}$ filha, eu pensei que nem estava, me atacou garganta febre, tudo, ai fui pra médica e ela disse que eu estava grávida. Na época minha mãe ainda estava viva ela que me levou pro médico. Depois tive o menino que tem oito anos. O meu menino mais velho tem 18 , o outro tem 15 a menina tem 14 e outro tem 8 , o mais novo tem cinco. E sempre usei pílula. $\mathrm{O}$ ultimo menino eu tomei desde a penúltima eu não tomei nada e não ficava grávida, e sempre ia ao médico e ele me perguntava o que estava usando. E não engravidava. Depois com o tempo o médico passou uns exames pra fazer de colesterol, de diabetes, um bocado, fazendo esses exames acho que fiquei grávida assim. Depois fiz preventivo tudo isso (pergunto se fez algum tratamento) não, mas acho que foi por isso. Eu só ia ao ginecologista. No Hospital da Mulher fui a algumas palestras, sei dos métodos mas só queria ligar. Por que o anticoncepcional mesmo só me dava dor de cabeça, até hoje eu tenho problema de nervoso 
e acho que causado por ele. Sempre eu trocava de remédio; o único que não me prejudicou muito foi o que eu pegava no Posto de Saúde. Mas eu sempre comprava Microvilar Neovular me prejudicava, porque eu emagrecia muito e não me dava bem. Eu não quis botar o DIU, me dava medo botar o DIU, sei lá, acho que ia me prejudicar e tinha gente que falava que o

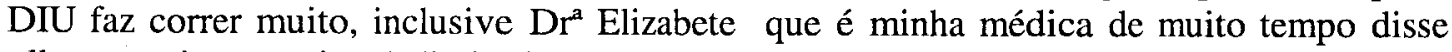
olhe, o anticoncepcional diminui o fluxo mas o DIU corre muito, tem gente que se dá e outras... Tem uma moça mesmo que colocou e ela disse que saiu do lugar que sentiu dor, ai sempre pensei prefiro logo é ligar.

Pergunta 2: Como você decidiu fazer a ligadura de trompas?

Mas foi meu marido sabe, eu fiz exames e a médica lá eu sempre falava para ela olhe Dra. está me prejudicando muito e pra todo dia tomando anticoncepcional. Ela disse pra eu pensar o que eu ia fazer, se eu queria ligar ou se eu queria ou se eu ia botar o DIU, ou se eu ia tomar a pílula; por que antes disso eu cheguei a tomar a injeção a "Deprovera", foi a Dra . Elizabete mesmo que passou, mas sempre faltava, a coisa mais difícil era Ter ela ai no Posto, ai ela passou o anticoncepcional e eu fui tomando mas esse não me prejudicou muito até o nervosismo é por causa disso. Ai eu falei com meu marido eu vou preferir ligar ai eu fiz o preventivo, exame de sangue e urina ai ele chegou aqui um dia pegou os exames e marcou pra mim; Foi até com uma moça que se chama Nete, ai eu fui dia 11 de dezembro e ai liguei, graças à Deus. Meu marido acertou tudo. Só que ai era muita dificuldade prá ligar não sei se ainda está. Quando eu estav grávida que ia lá no médico e falava prá ligar e eles sempre botava dificuldade e eu falava que já tinha muitos filhos que não tinha condições ai eles me tapeavam muito. No Hospital da Mulher foi assim ai me revoltei e disse não vou mais. Pedir ai eu fui pra ... ai ele ( o marido)) conhecia essa moça que trabalha com Tarciso, ai ele chegou e pegou meus exames e fez essa surpresa pra mim, e eu fui fazer lá em São Gonçalo. Eu fiz, por que já tinha filhos demais. O remédio pesou também, mas foi mais o número de filhos. Então eu fiz três abortos e na ultima gravidez, eu estava tomando a injeção, a injeção era de três em três meses e sempre tinha que esperar a mestruação para voltar a tomar, ai nesse ficar esperando foi que eu fiquei grávida eu fui na doutora e disse que estava sentindo dor ela me examinou e disse que eu estava grávida. Ah ! eu disse não é possível, ainda falei da injeção que estava tomando. No exame de urina pra eu fazer deu e eu disse meu Deus me perdoe mas não vou ter esse filho não. Ai logo que vai continuar assim eu vou tomar o anticoncepcional, não vou querer mais injeção, vou tomar até chegar o dia que Deus mandar o jeito de fazer a ligação, ai tomei até o dia que eu fui fazer a ligadura só tinha um e eu não ia jogar fora né?

\section{Pergunta 3: Você teve alguma informação sobre a ligadura de trompas? De quem?}

$\mathrm{Eu}$ sempre falava que eu não queria estar amarrada queria que tirasse as trompas porque não queria mais ter filhos, porque o tanto que eu tenho já é suficiente. $E$ ai as meninas que iam ligar lá em São Gonçalo eu sempre perguntava e lá eles faz como? Elas disse lá ele estrangula mesmo, e eu disse é isso que eu quero prá não ter mais filho, porque tem uns médicos ai que dá nó, e eu disse então não quero, eu quero uma coisa bem feita. Por que Dr. Tarciso aqui mesmo, dizem que a ligadura dele é que amarra é no umbigo né? e eu disse assim não quero, quero é que estrangule mesmo. Ai lá em São Gonçalo as meninas estavam indo - porque eu não tinha coragem de perguntar ao médico mesmo - eu disse ele estrangula mesmo, ela disse estrangulou. Eu perguntei a $\mathrm{Dr}^{\mathrm{a}}$ Elizabete e ela disse que era melhor eu ligar que era melhor prá mim. E eu disse a $\mathrm{Dr}^{2}$. Mas eu tenho medo. E ela disse não, e só Ter o resguardo. (Pergunto qual era o medo) de ligar, principalmente da "raque" que a gente toma eu tinha medo de ficar com problemas, sabe? Era isso que eu tinha medo. E logo que eu tomei a anestesia lá me parlisou as pernas que me deu agonia. Eu liguei umas 04 horas da tarde, meia noite ainda não tinha equilíbrio nas pernas e eu tive medo. Logo paralisou minhas pernas e até hoje eu sinto dor na perna que não me aguento mas acho que é mais por 
causa das varizes. A anestesia ajuda também que é muito forte é enorme a coisa (agulha). Me deu muita dor de cabeça, sei lá eu senti dor de cabeça desde a saída do hospital, quando cheguei aqui, cheguei doida e não levantei, não sei se foi o balanço do carro, só sei que fui parrar na Casa de Saúde no outro dia. Ai o médico me medicou e nada de passar isso foi de Quarta a Sexta-feira, deitada até que ficava bem, quando levantava... parecia que a nuca ia soltar. Aí minha irmão que trabalha no Posto de Saúde me arranjou um remédio foi que graças a Deus que tomei e parou a dor de cabeça, por que já estava em tempo de enloquecer. Porque lá não faz revisão sabe, não faz ai, demorei uns dias fui a $\mathrm{Dr}^{2}$. Elizabete e contei a ela tudo; ela passou remédio prá mim. Sempre eu perguntava a minhas irmãs que ela ligaram mas elas fizeram pelo umbigo, não tirou as trompas, e a minha ele disse que estrangulou mesmo. (Pergunto se ainda tem medo de engravidar?) Mesmo assim tenho, sei lá porque as vezes muita gente, não sei se fez assim como eu fiz, mas muita gente que engravidou depois. A minha irmão mesmo a filha dela mais nova está com 16 anos e ela ficou grávida, ai eu disse a ela olha, vou Ter que fazer uma coisa bem feita, por que até hoje ás vezes à noite, vem aquele pensamento do remédio pra eu tomar. Eu ainda tenho medo a mestruação não chegou ainda. Se não chegar, eu vou lá $\mathrm{em} \mathrm{Dr}^{\mathrm{a}}$. Elizabete pergunta por que não veio. Fico muito nervosa, morro de medo, meu Deus. Olha eu fui fazer em São Gonçalo, a besta leva 16 pessoas, no dia que fui fez as 16 pessoas, faz todos os dias. Entrava de duas em duas. $\mathrm{O}$ quarto fica com oito camas, é muita gente.

\section{Entrevista 20}

Pergunta 1: Como você fazia para evitar filhos desde o começo de sua vida sexual?

Eu nunca evitei filhos, nunca tomei remédio pra evitar, e nunca fiz nada, desde o primeiro marido, o meu primeiro filho está com 12 anos, nunca fiz nada o outro filho está com 05 anos e este que nasceu agora. Nunca fui ao Posto de Saúde fui fazer um pré-natal do menino de 05 anos, desse eu fiz no hospital.

Pergunta 2: Como você decidiu fazer a ligadura de trompas?

Porque não queria parir mais não, os meus partos são meio complicados tudo com anestesia e ai eu resolvi ligar logo. Os três foram cesárea e eu já estava com medo de anestesia. E quis ligar porque ligar é mais seguro.

Pergunta 3: Você teve alguma informação sobre a ligadura de trompas? De quem?

Não, meu marido que ficava dizendo que conversasse com o médico que se ele me ligasse era uma boa. Não conversei com ninguém. Falei com o médico na hora do parto que se ele queria me ligar que era uma boa. Antes eu não conversei nada. Porque quem fez o meu prénatal foi Dr. Fiscina, só que quando eu dei a dor o médico era outro, e com Dr. Fiscina também eu não conversei, eu ia conversar, por que eu vinha na Quarta, mas na Terça dei a dor. Durante o pré-natal, eu vinha mas não tinha coragem de pedir a ele, porque o povo dizia que era pago e eu tinha medo. Só conversei com o meu marido com mais ninguém.(alguém falou de arrependimento) - não, mas eu já tenho três filhos, trabalho, é muito ruim. Já ouvi falar de outros métodos. O meu marido falou se você não operar vai botar o DIU ou pegar remédio no Posto mas eu sempre preferir ligar. Eu queria esperar pra ver se era filha mulher e ligava ( e se não fosse mulher) eu ligava do mesmo jeito, ai na hora do parto eu pedi e ele ligou, ele ainda falou você tem uns partos muito ruins podia aproveitar e ligar logo. Não sei o que ele quis dizer não. Eu já estava perdendo água desde 08 horas e fiz o parto a meia noite. Eu sempre disse a tomar remédio eu prefiro ligar. 


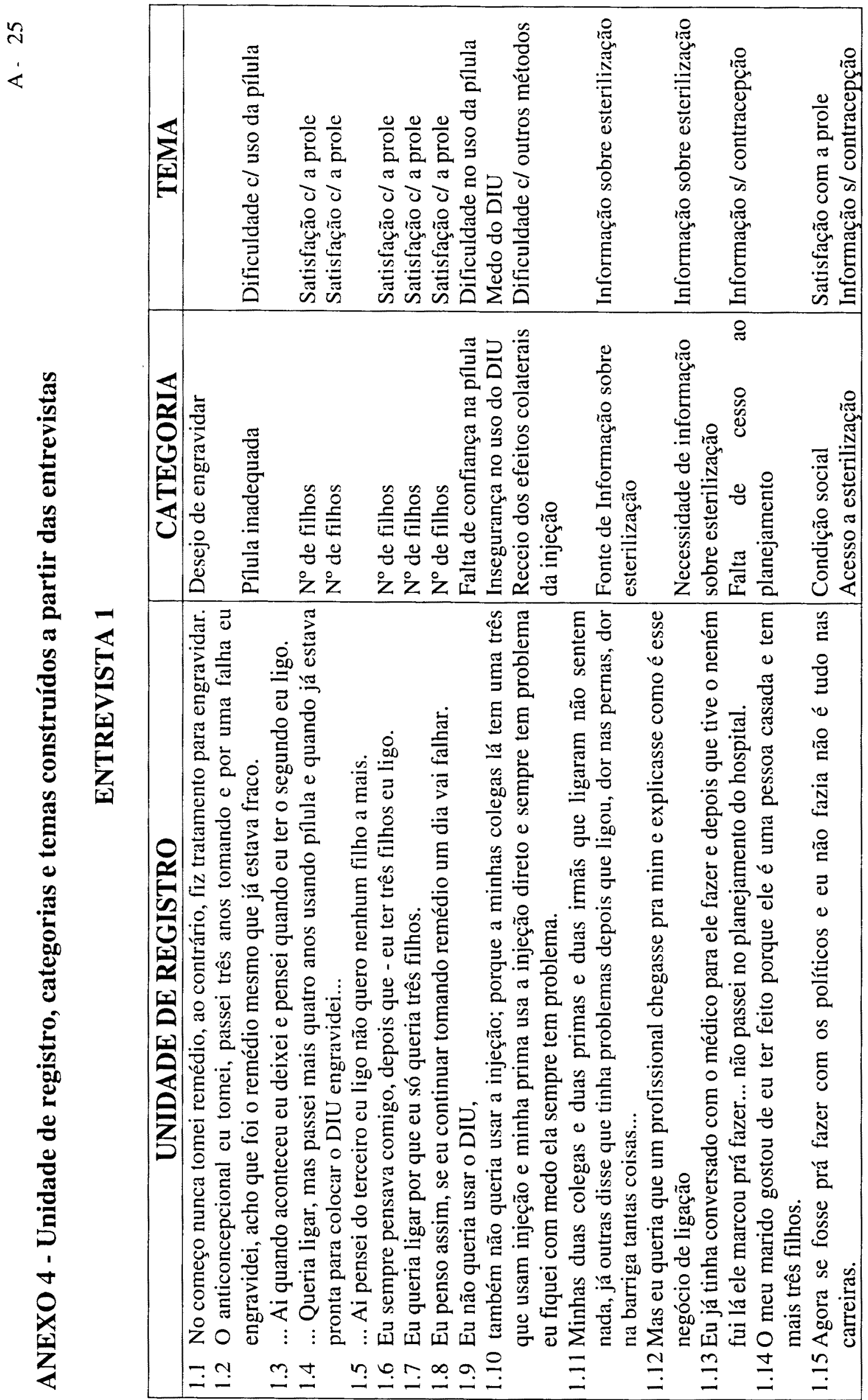




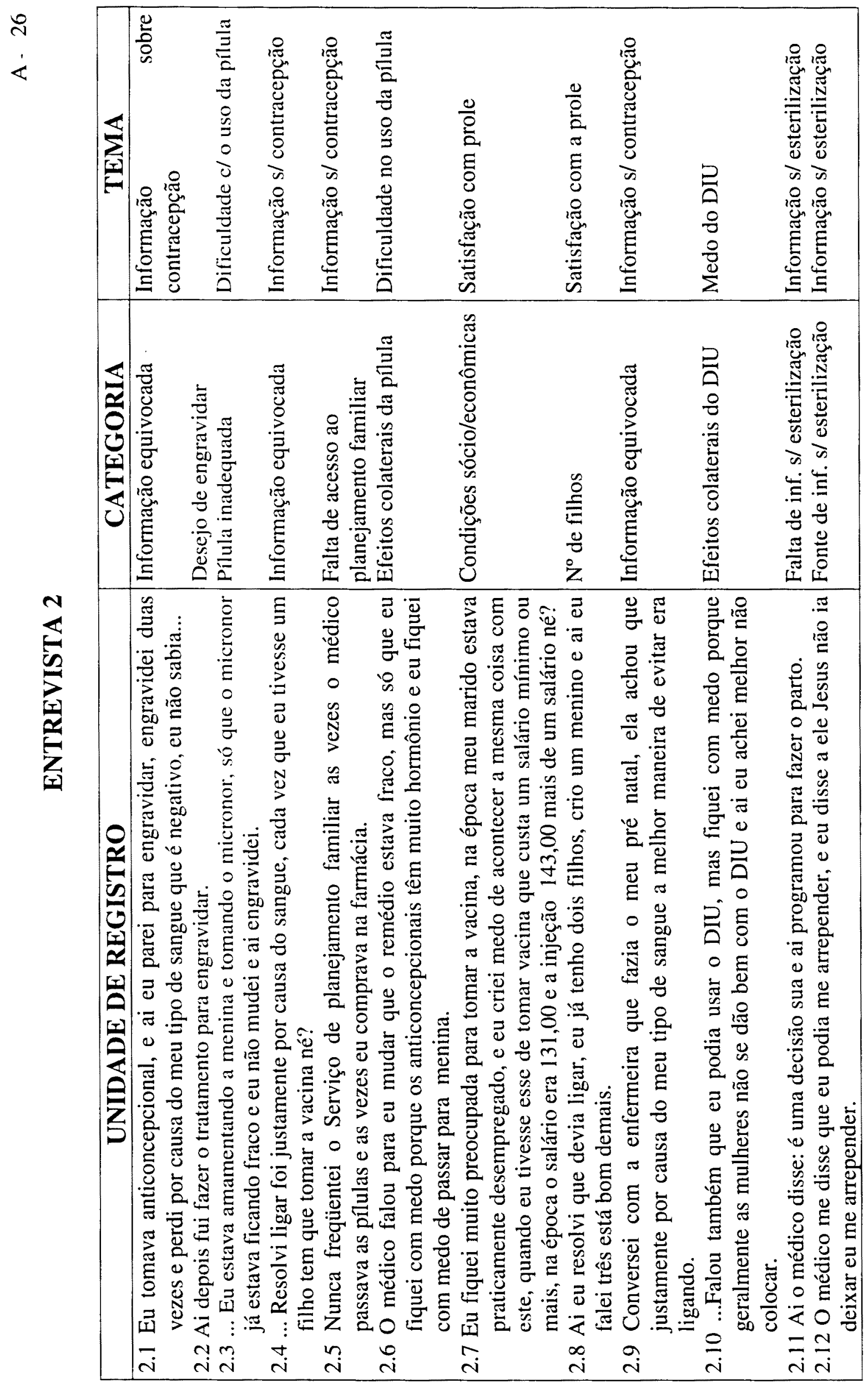


$\grave{2}$
$<$

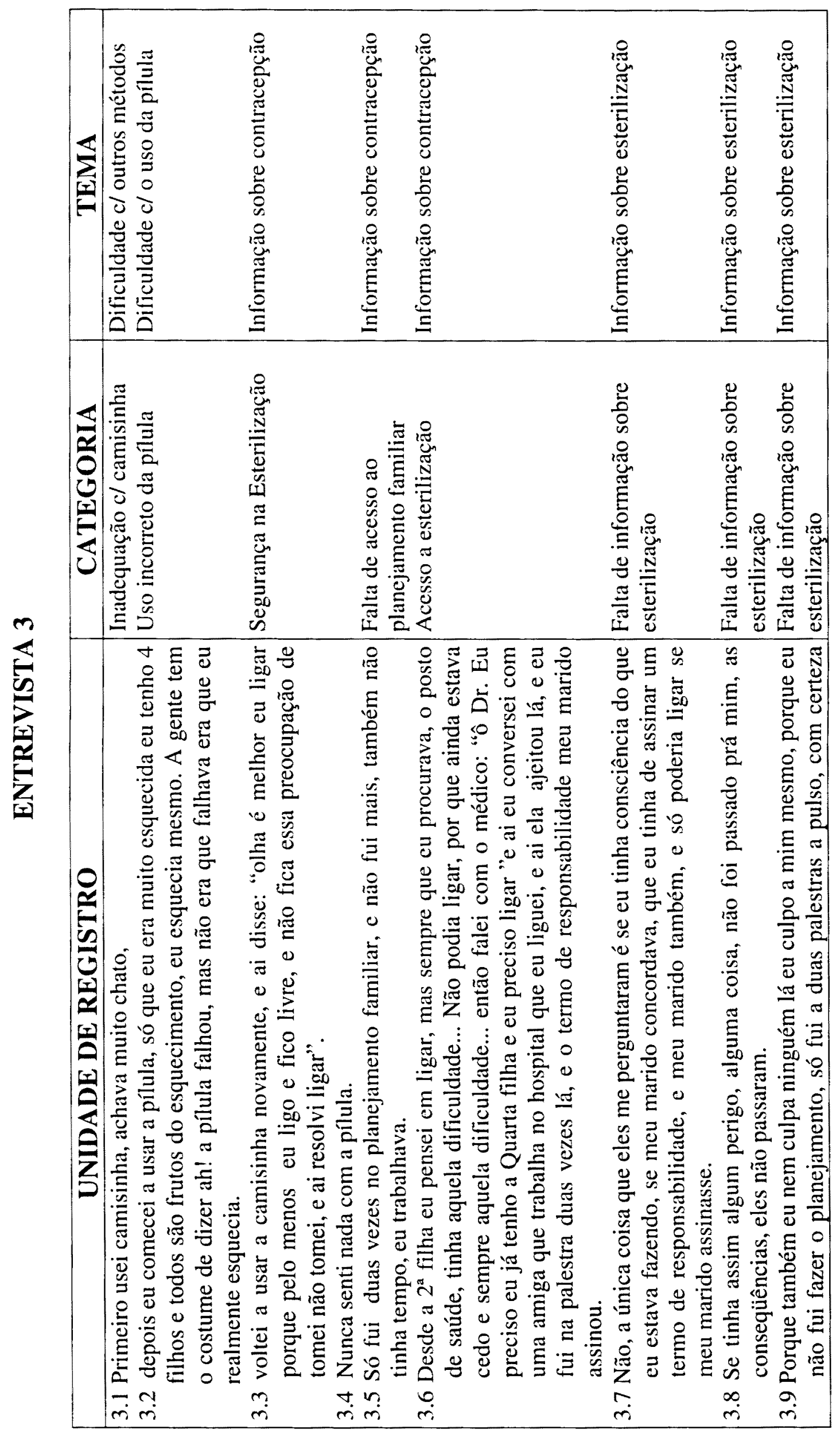




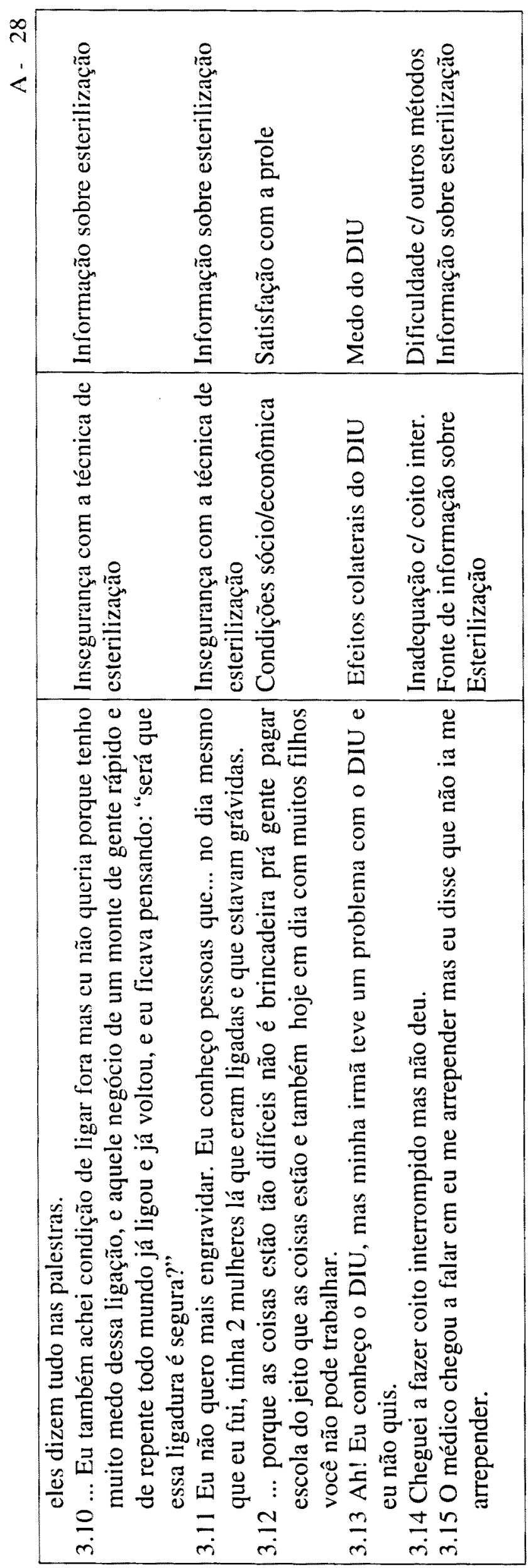


ते
$\dot{4}$

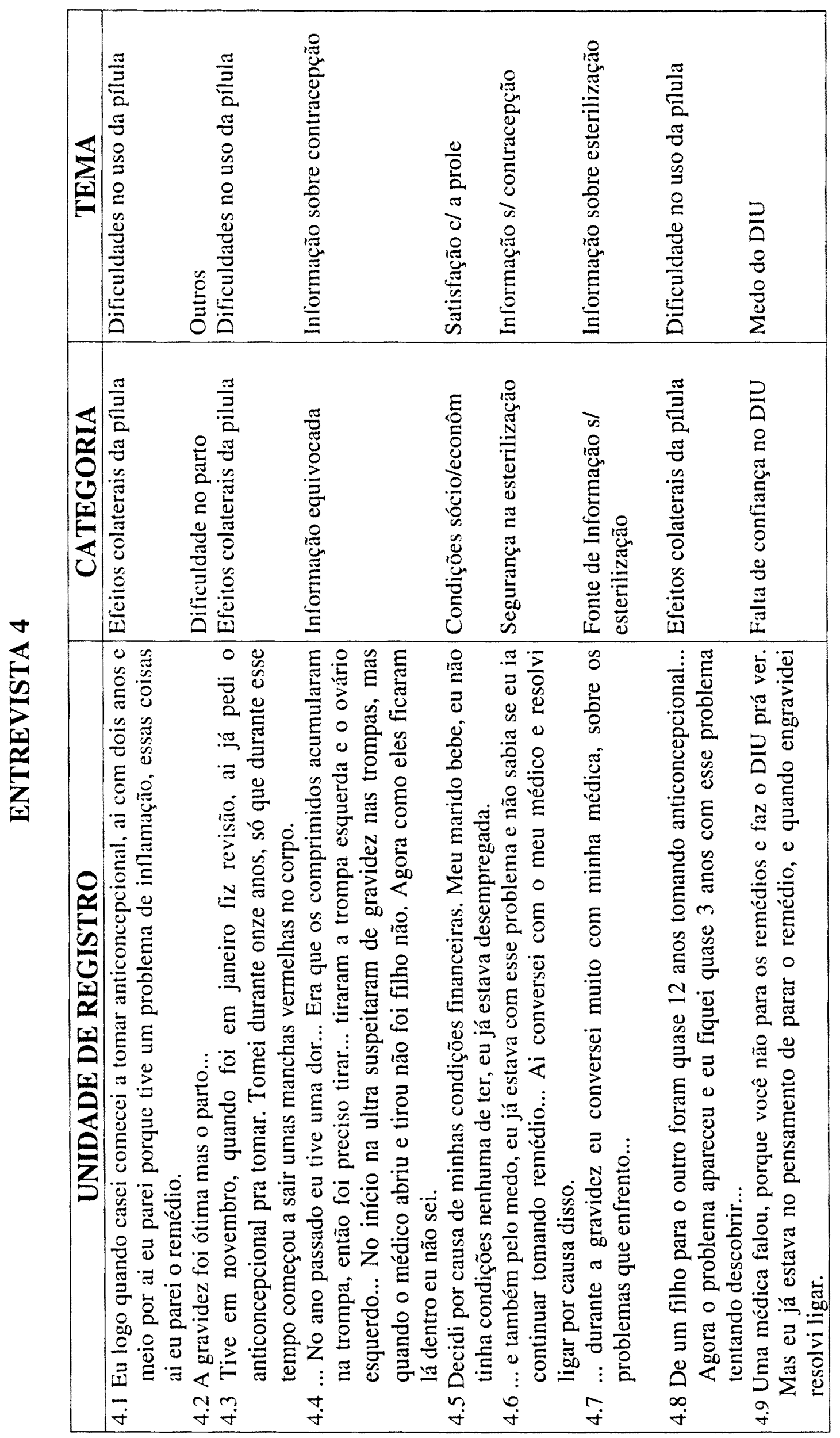




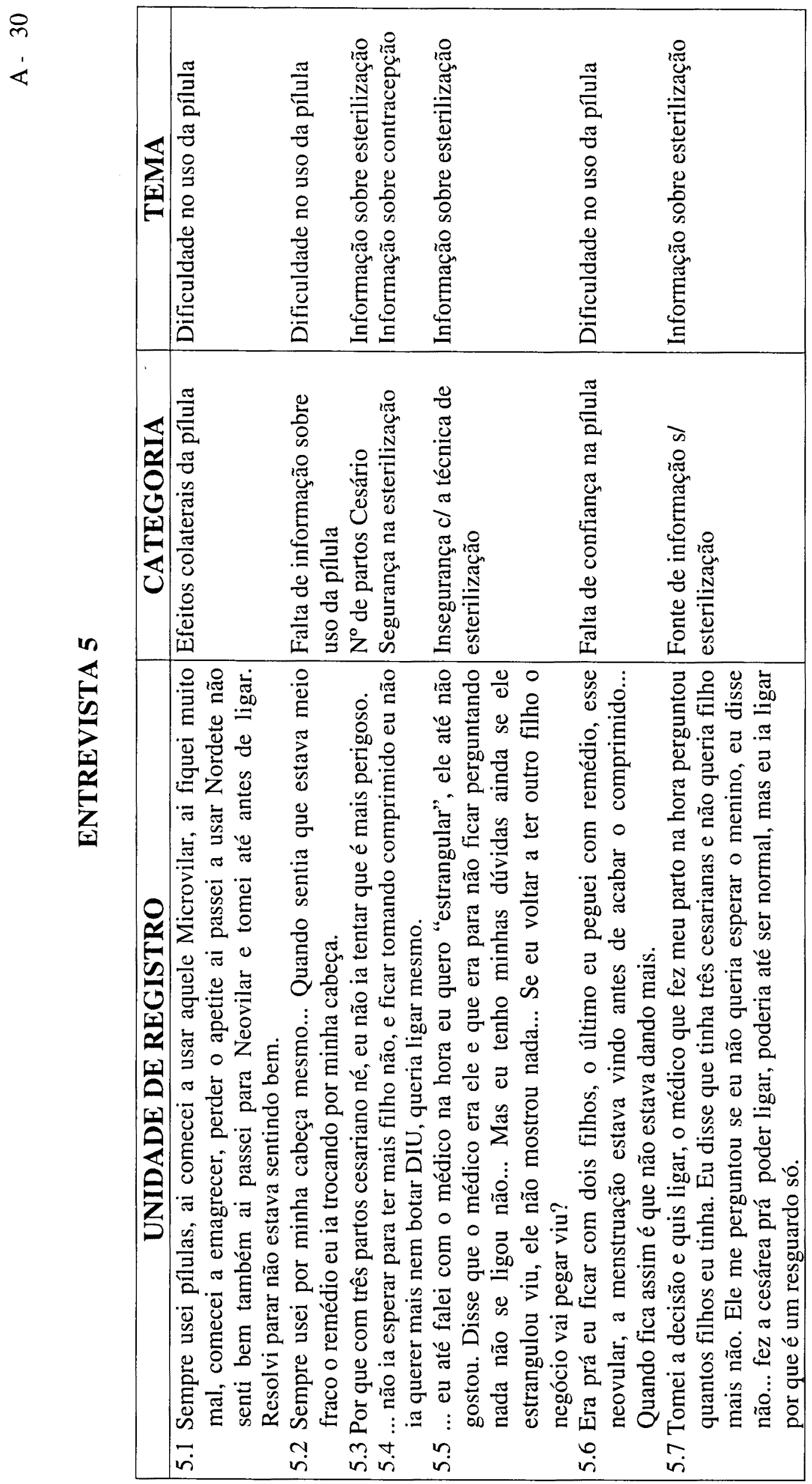




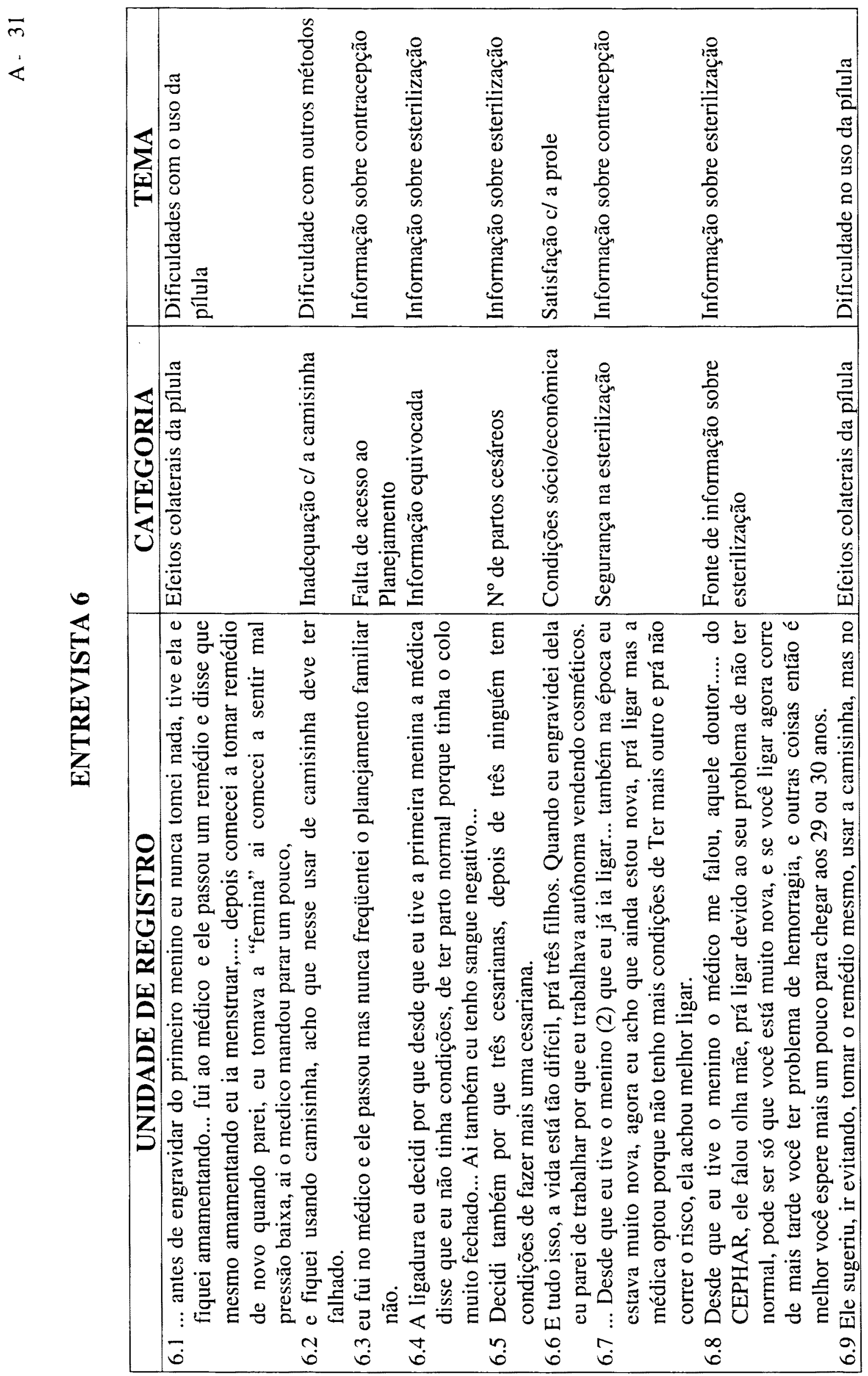




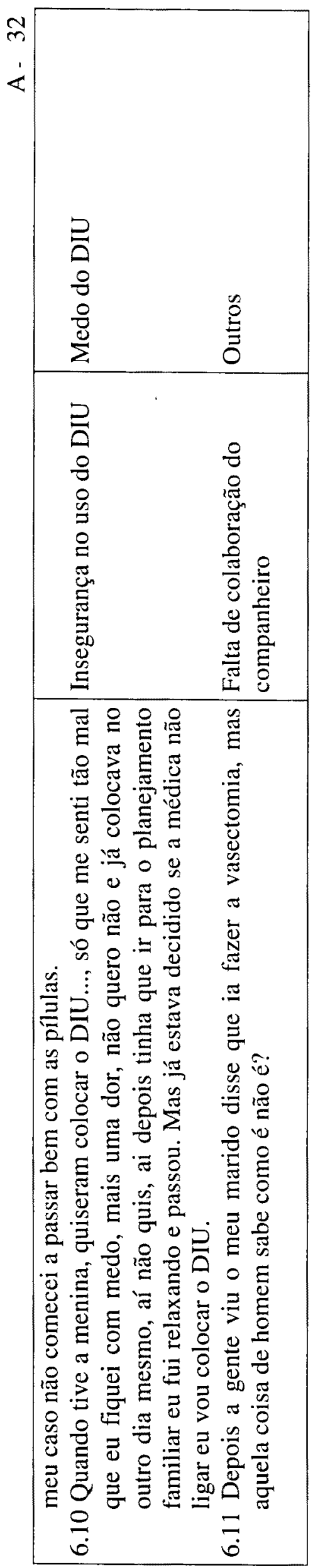


m

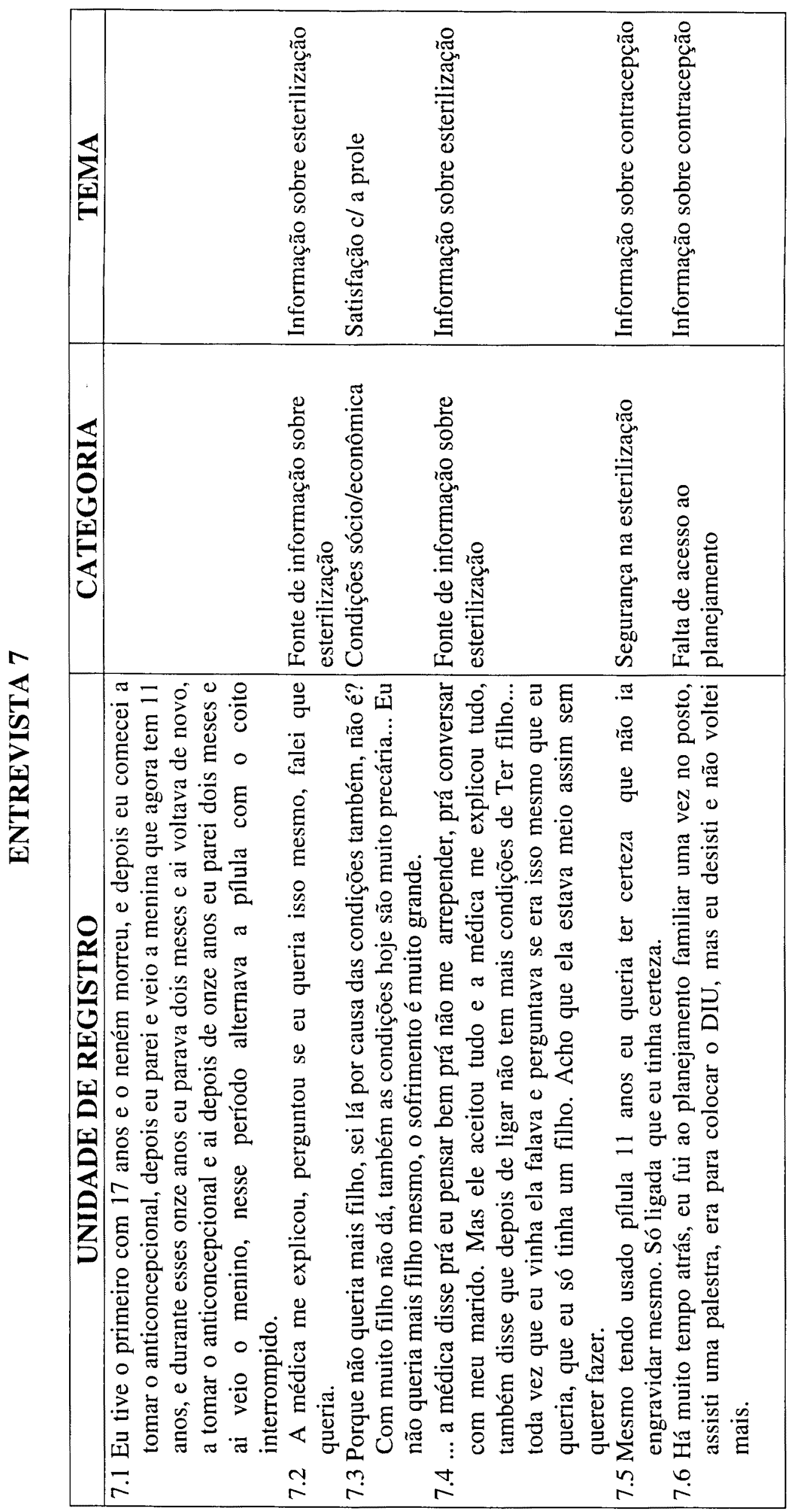


4
$\dot{2}$

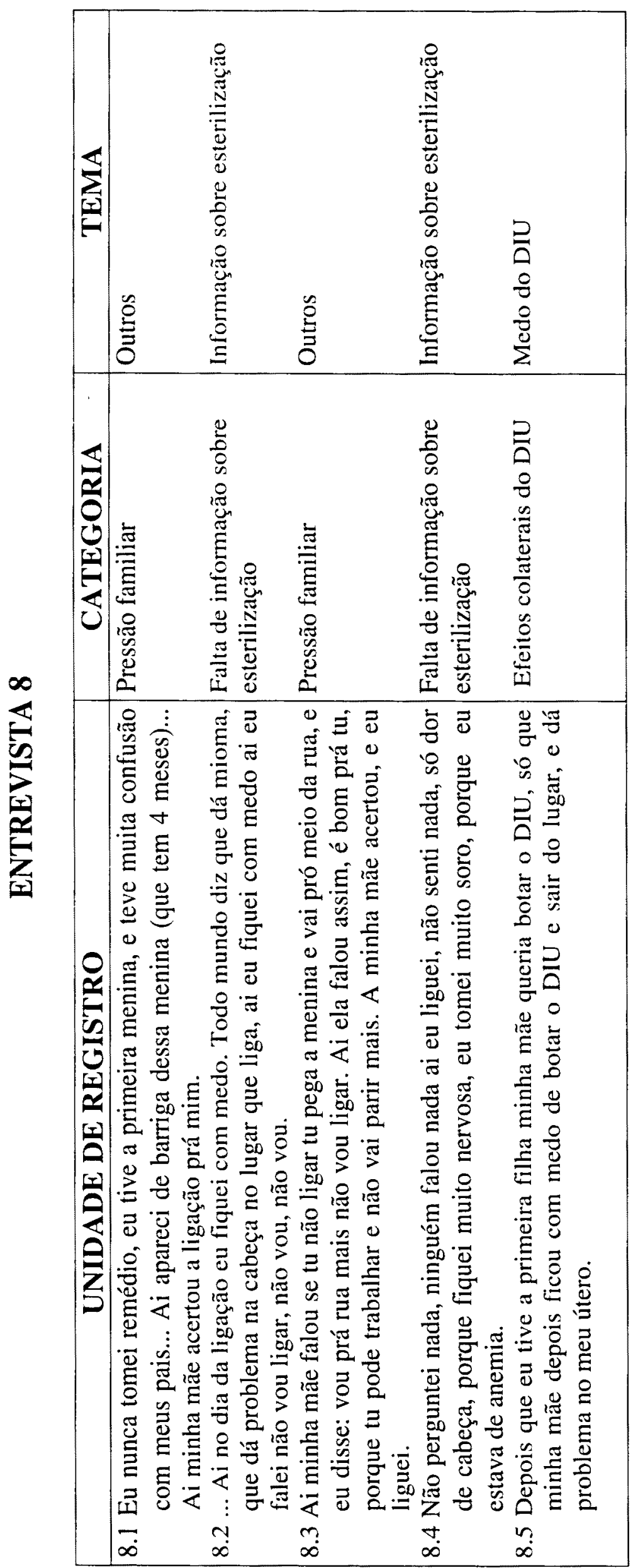


$\ddot{8}$

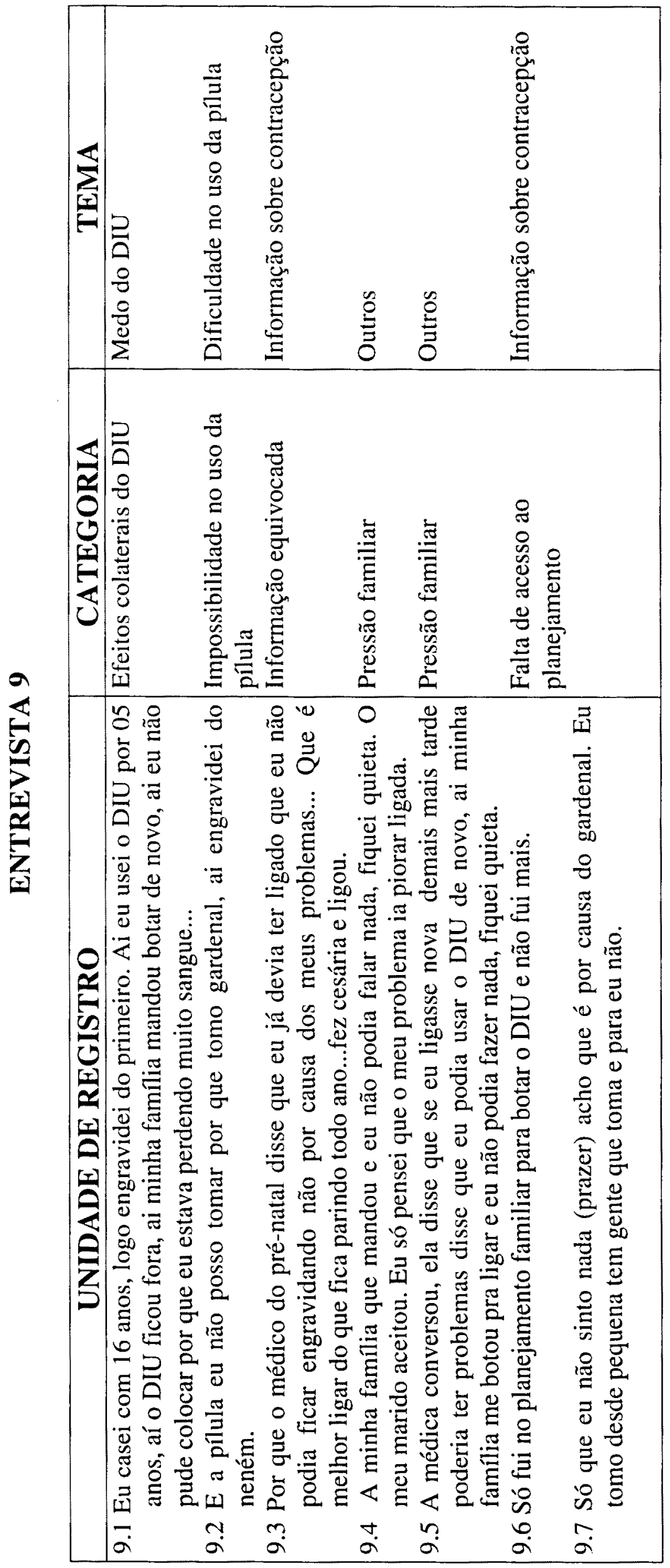




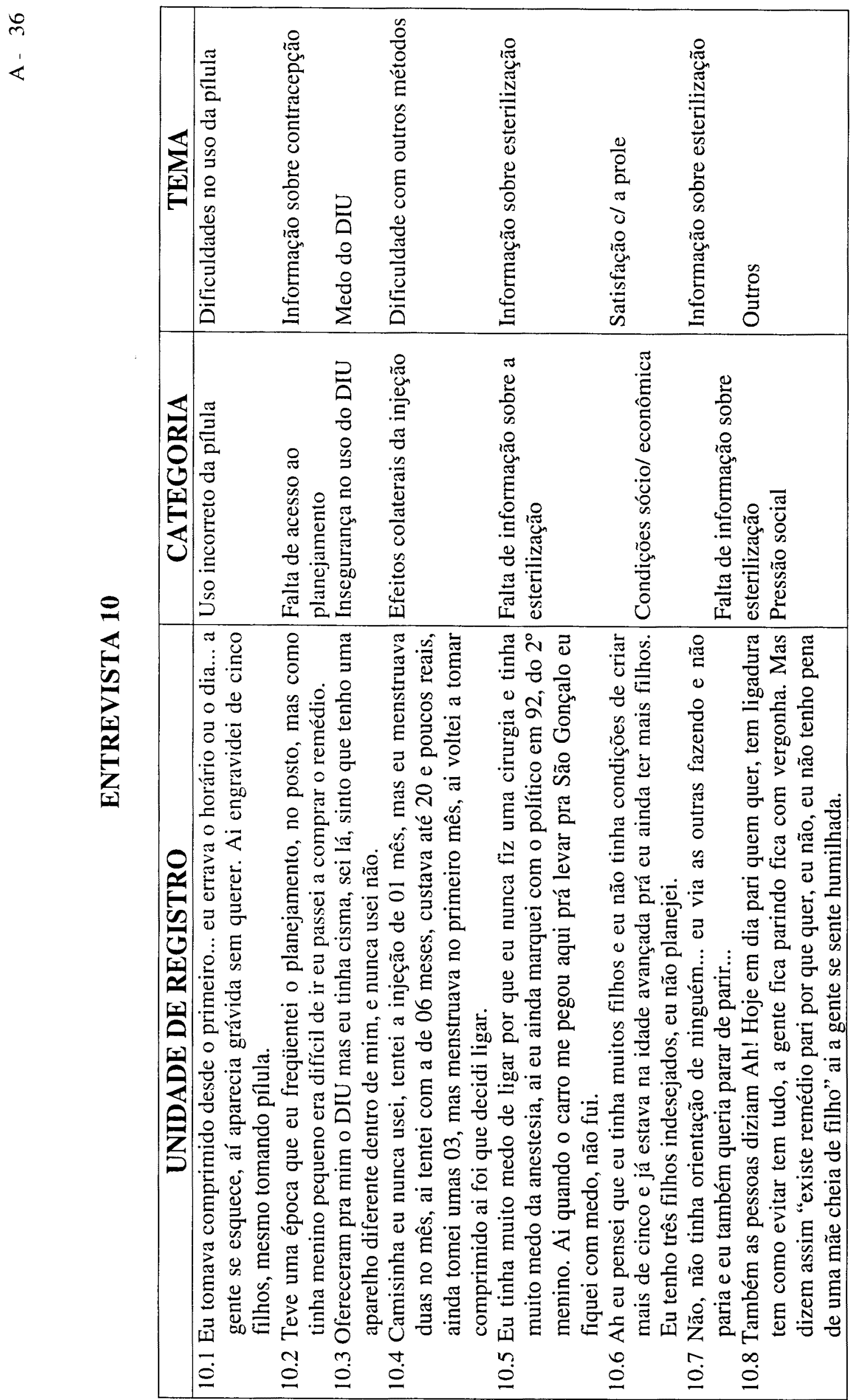




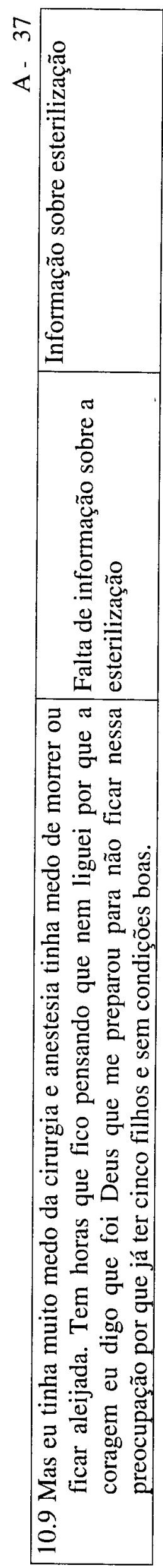


$\stackrel{\infty}{<}$

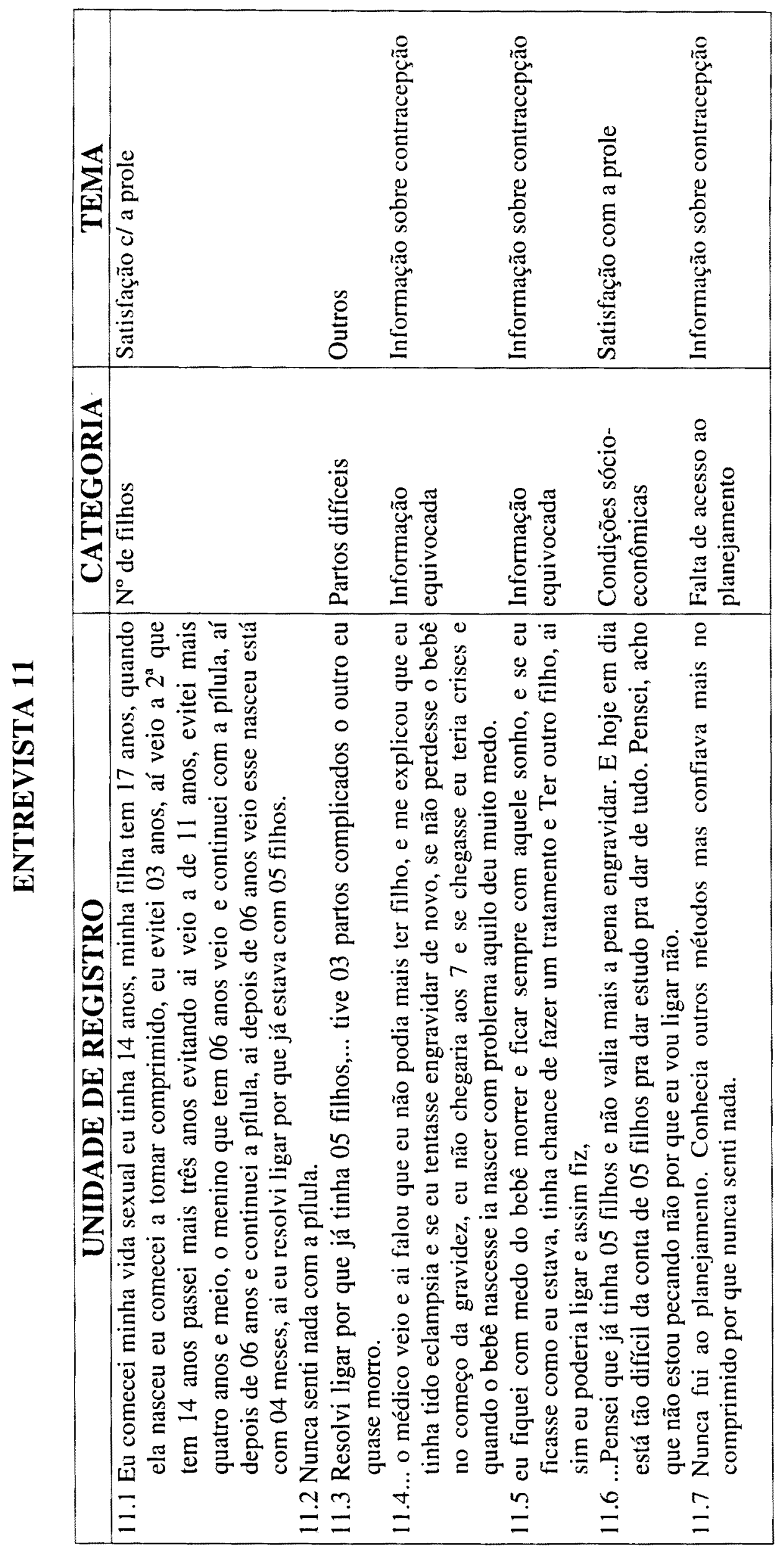




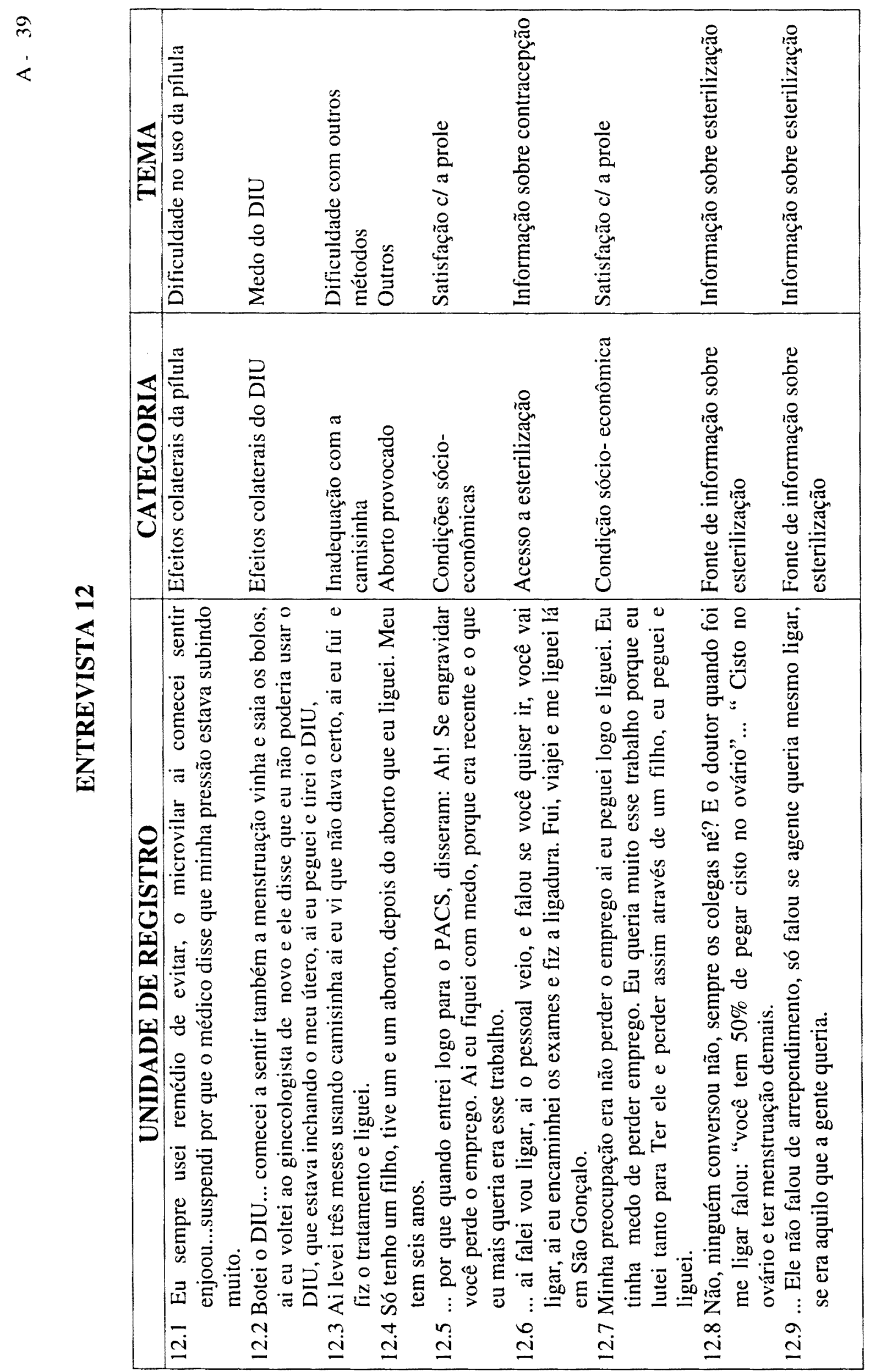




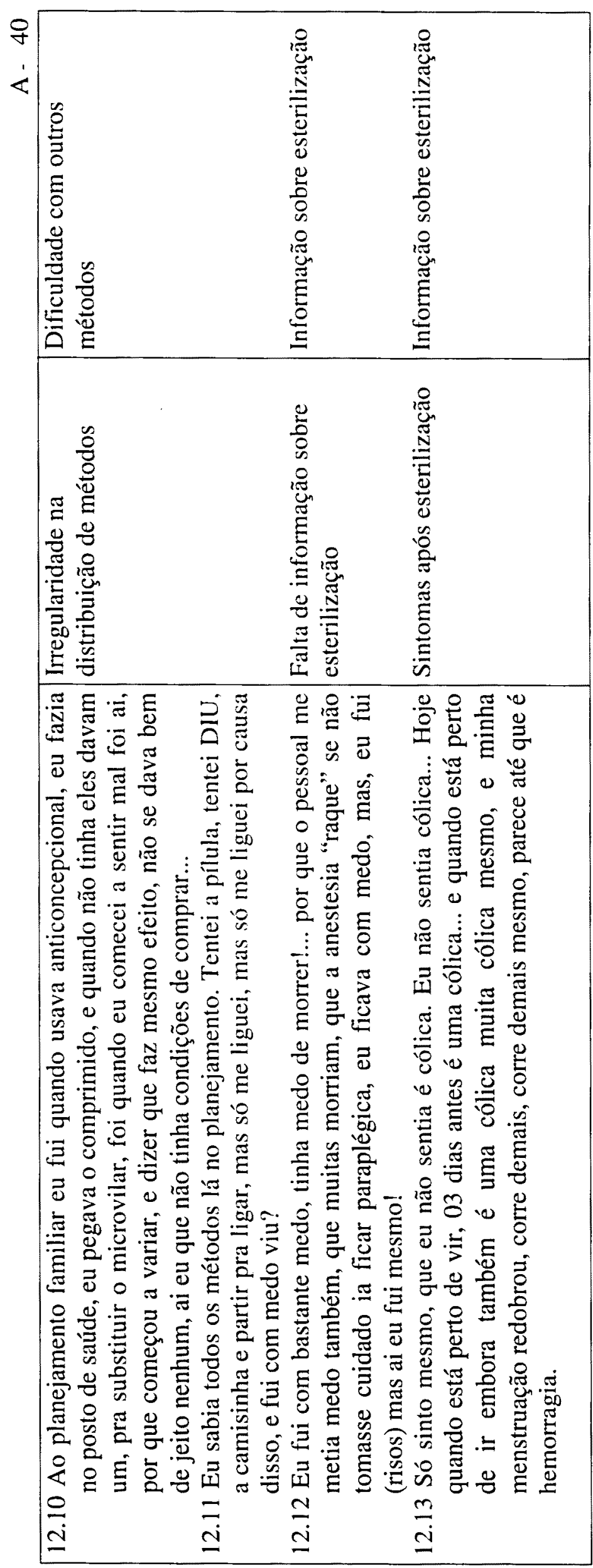




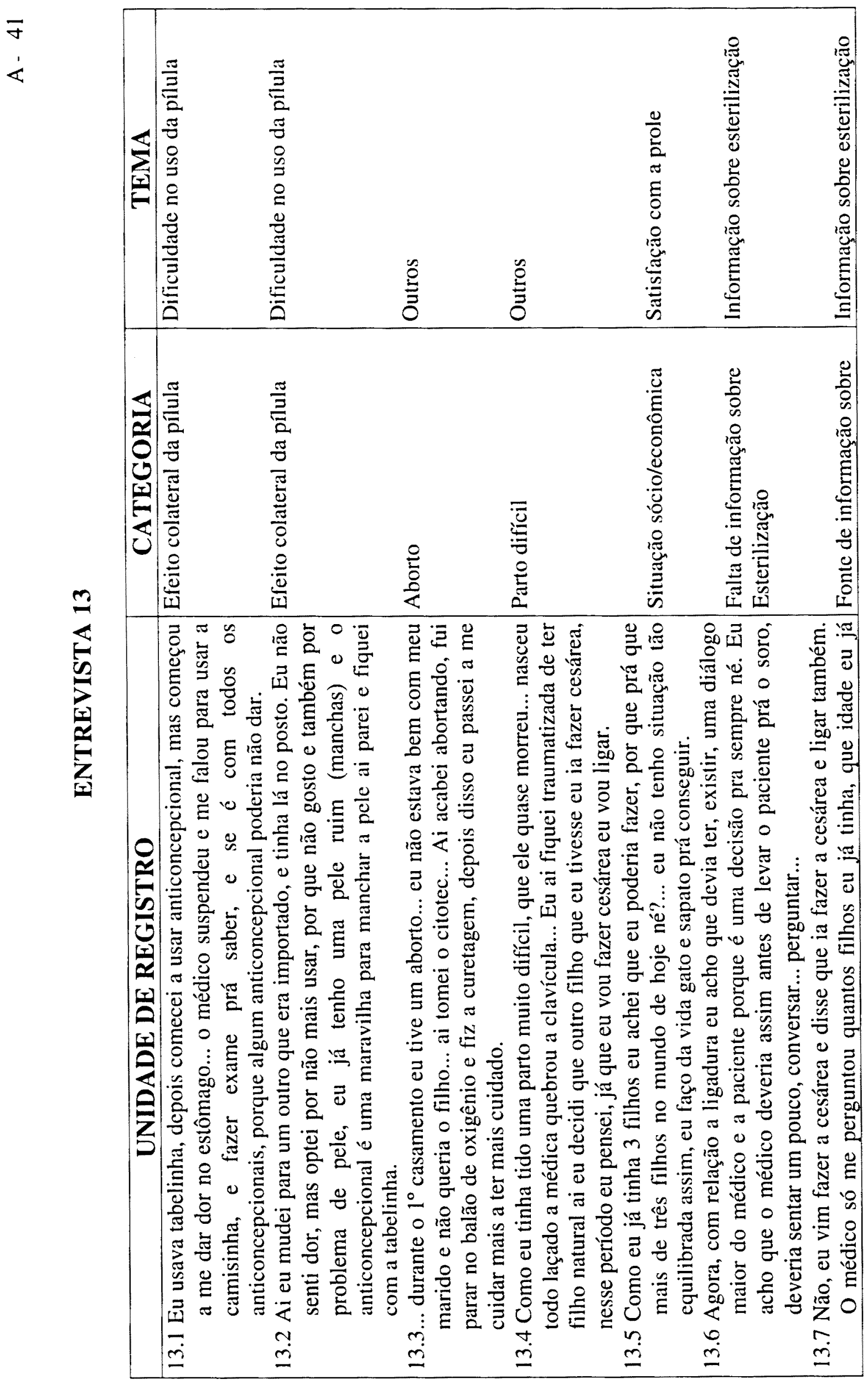




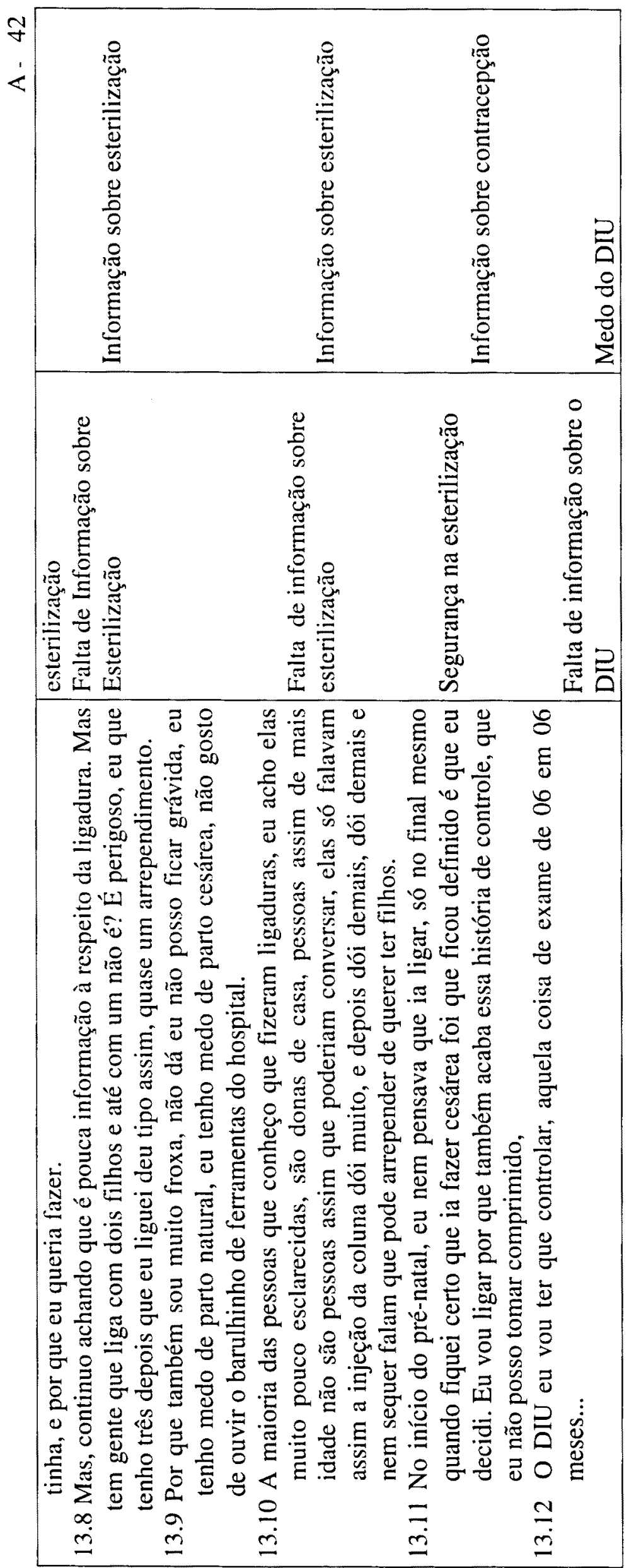




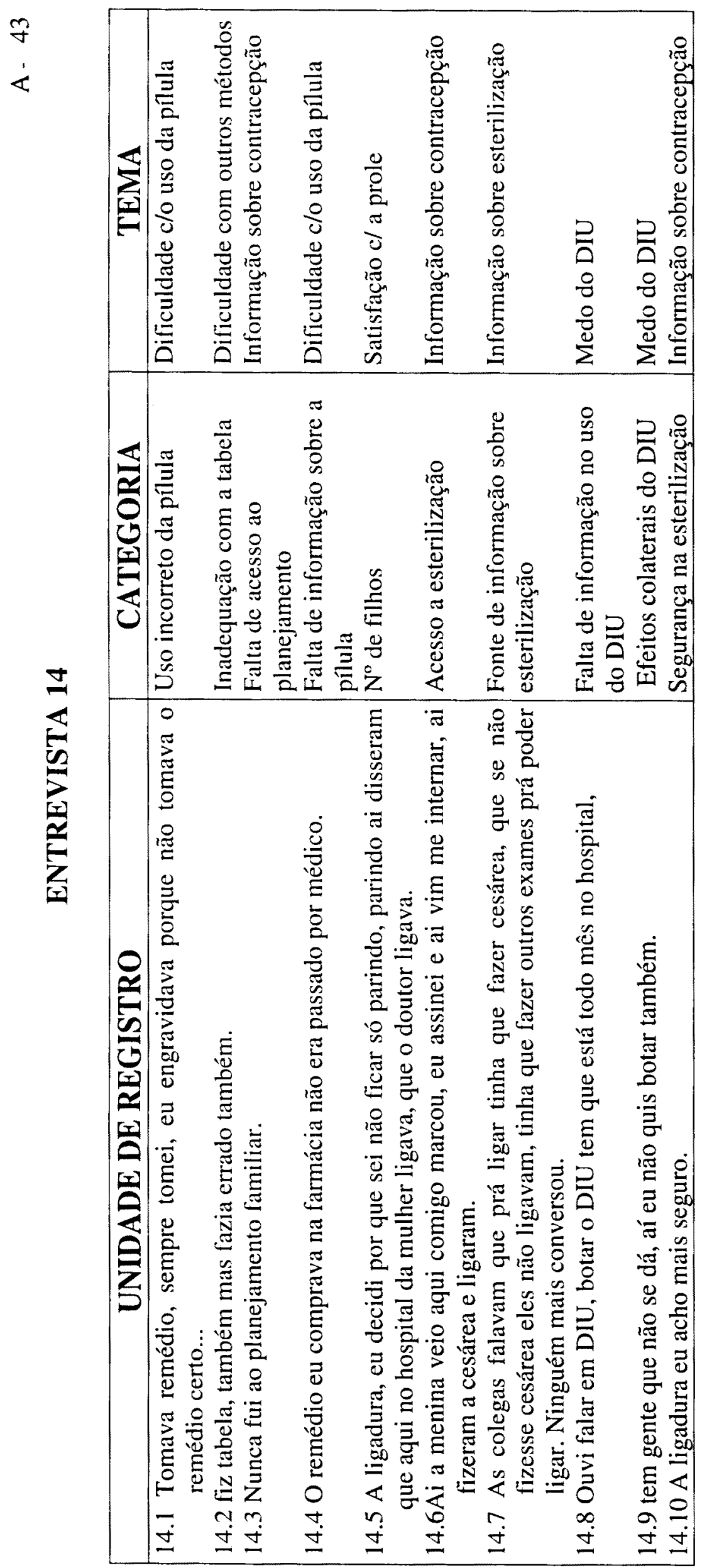


$\exists$
$\varangle$

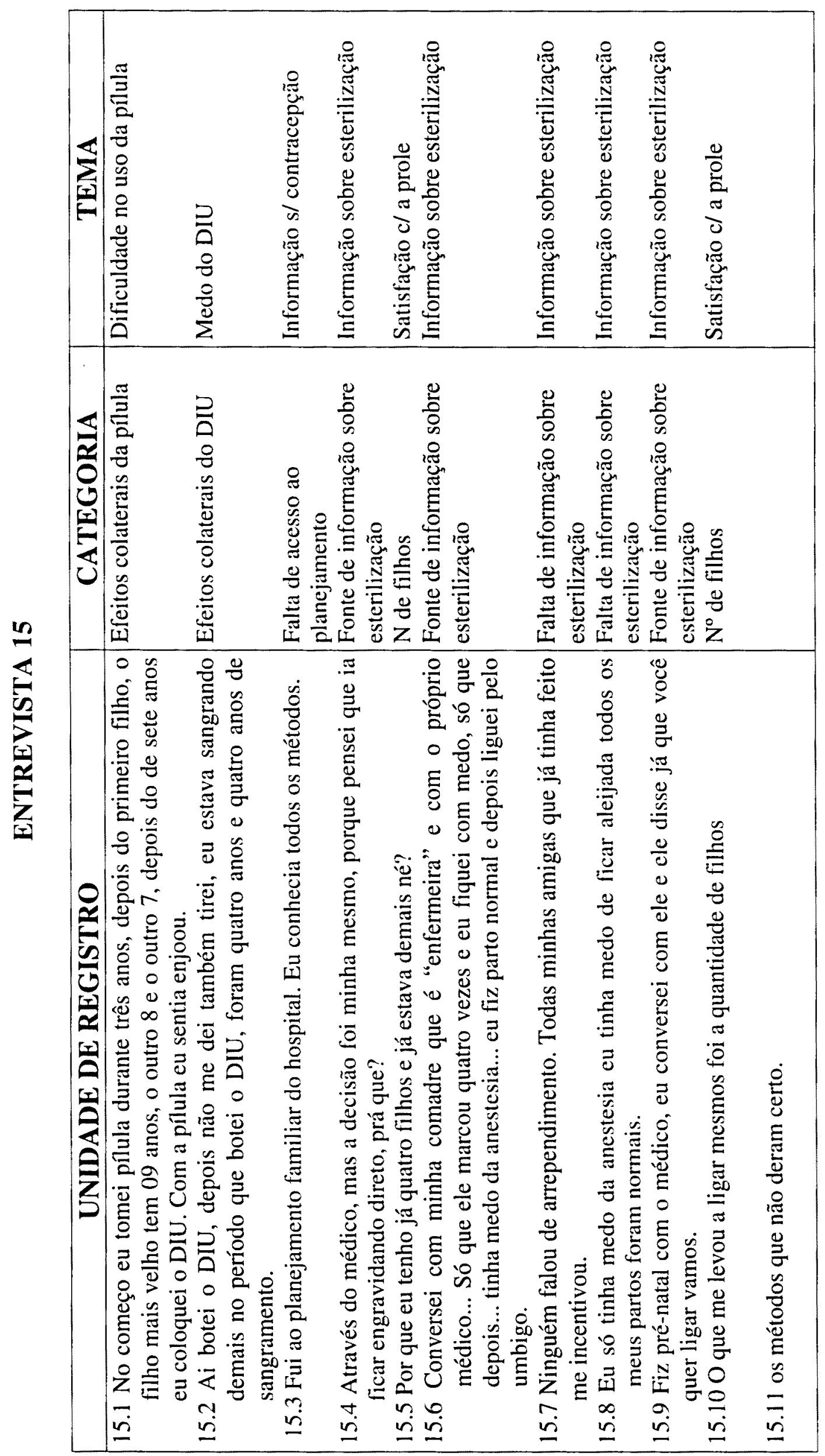


字

\begin{tabular}{|c|c|c|c|c|c|}
\hline 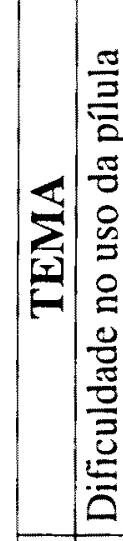 & 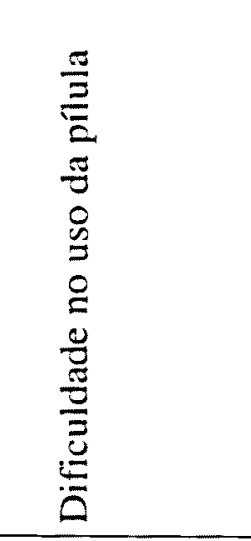 & 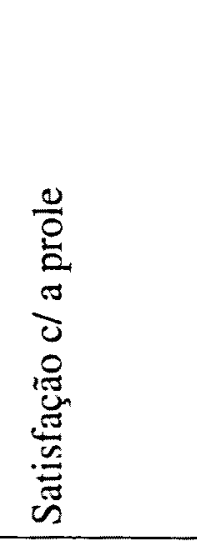 & 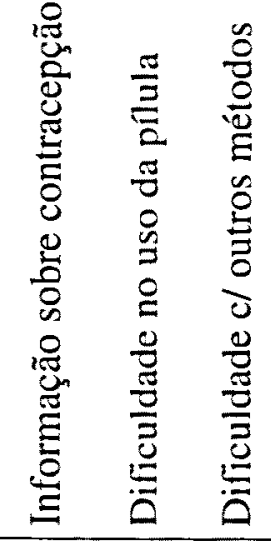 & 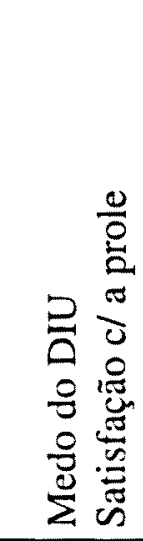 & 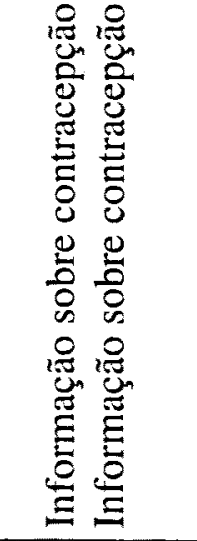 \\
\hline 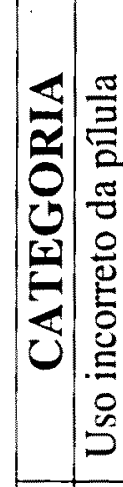 & 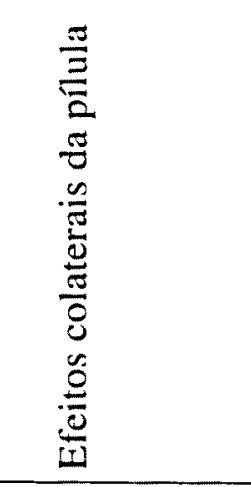 & 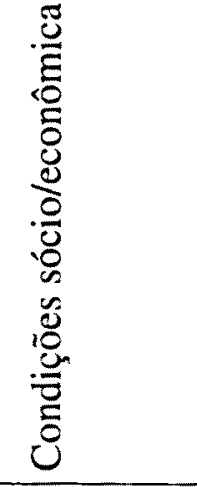 & 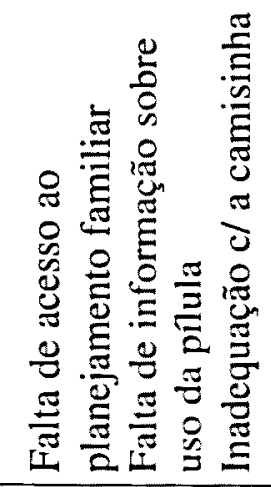 & 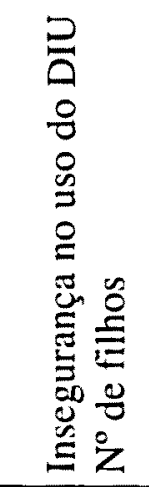 & 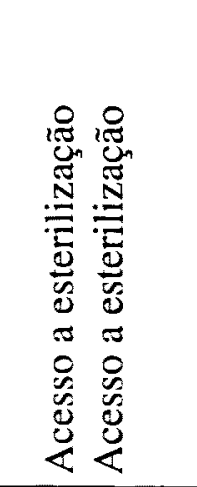 \\
\hline 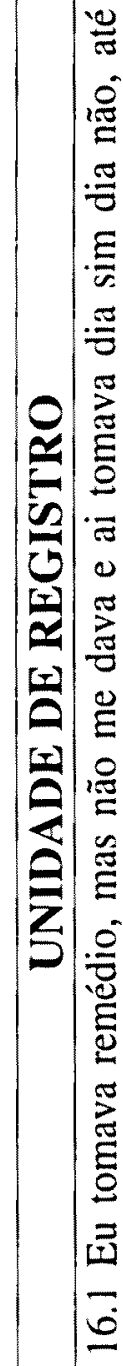 & 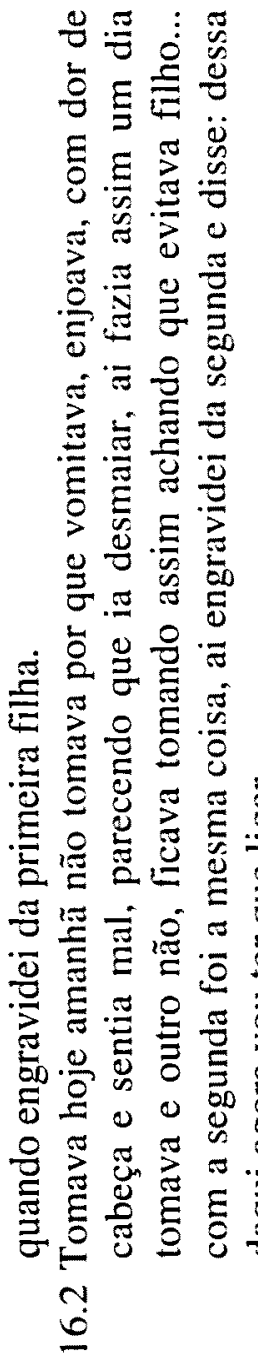 & 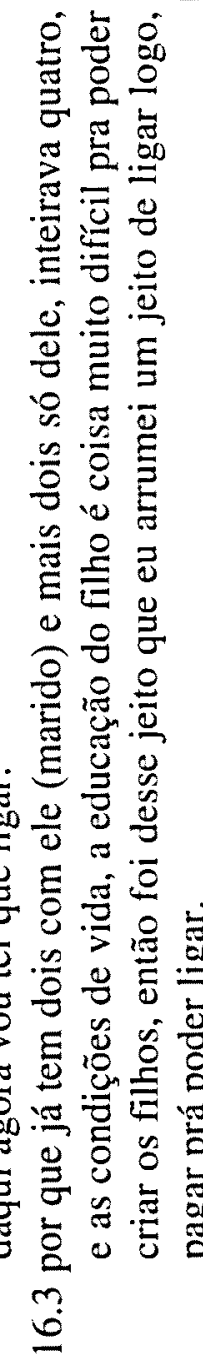 & 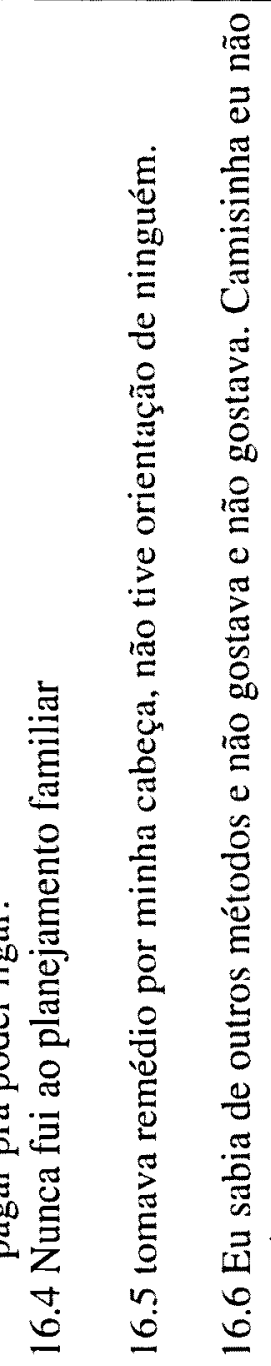 & 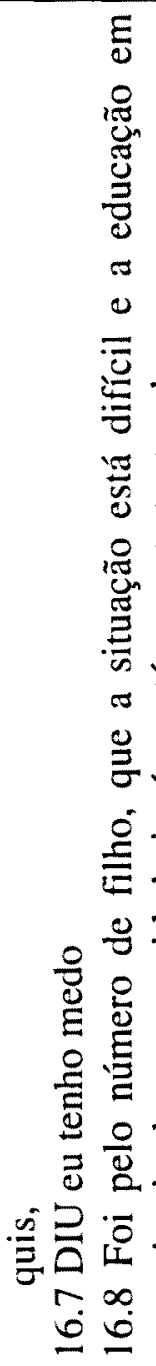 & 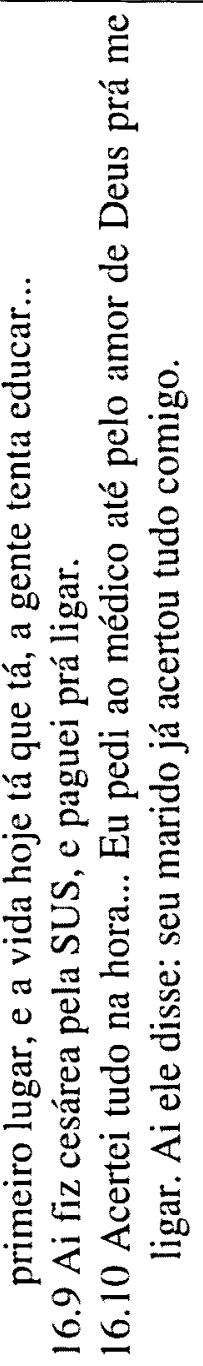 \\
\hline
\end{tabular}


\&

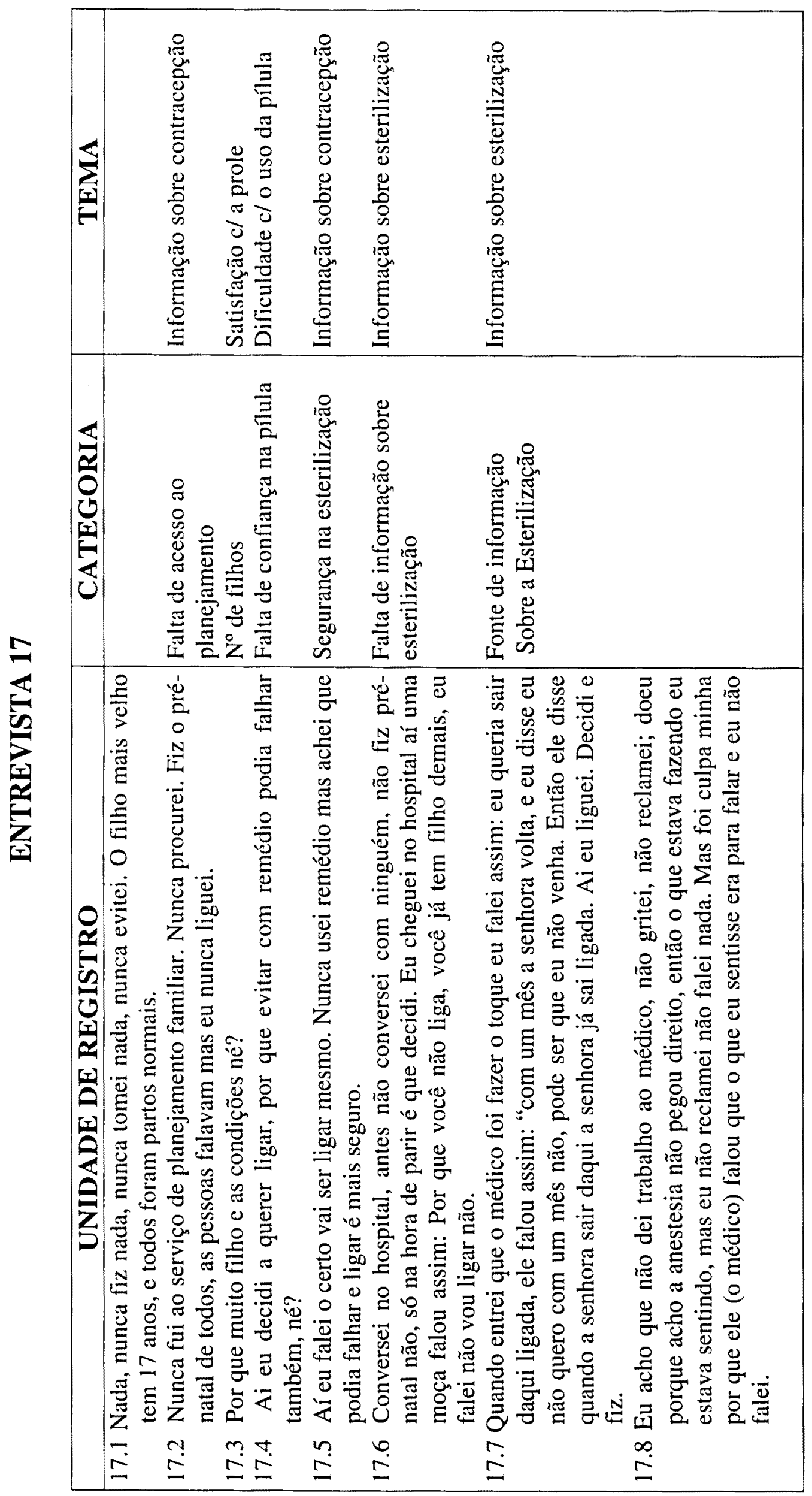




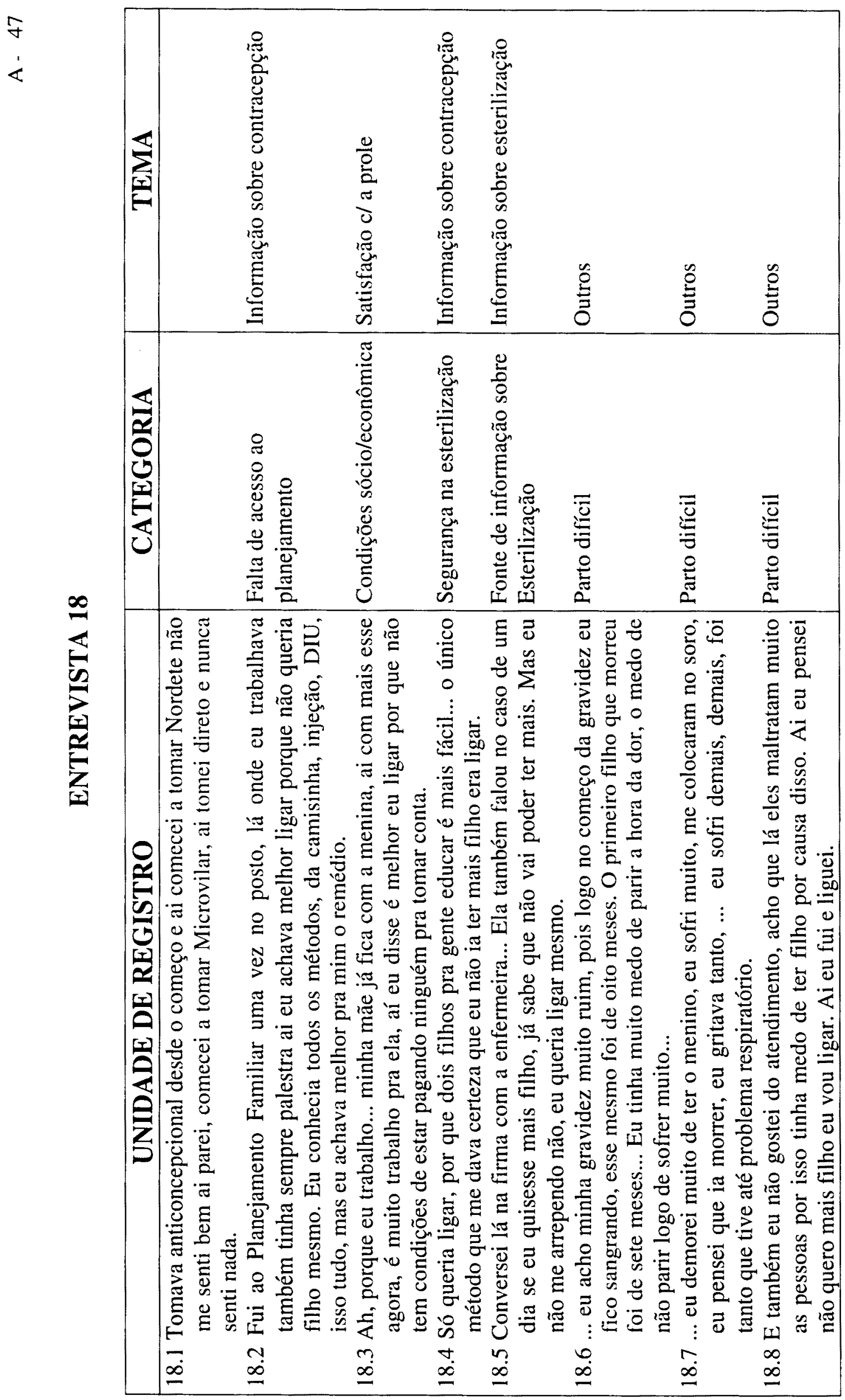


$\stackrel{\infty}{+}$
$<$

\begin{tabular}{|c|c|c|c|c|c|c|c|}
\hline 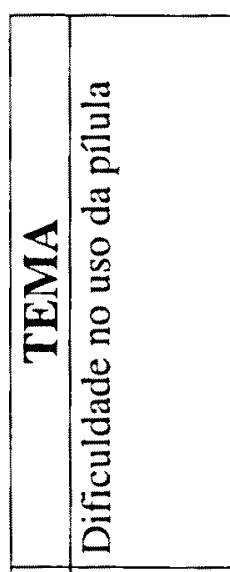 & 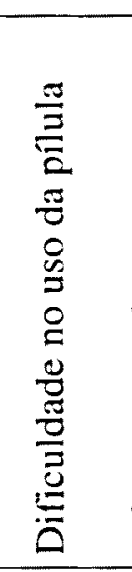 & 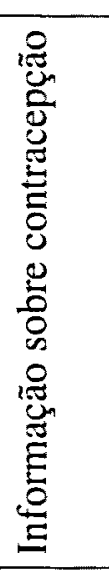 & 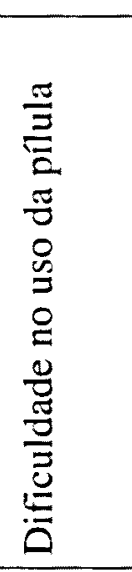 & 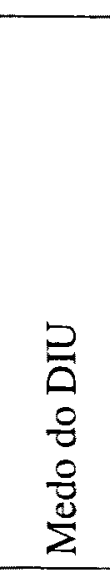 & 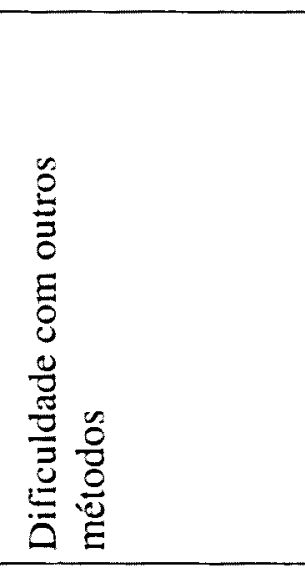 & 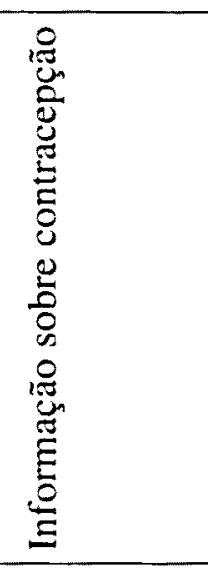 & 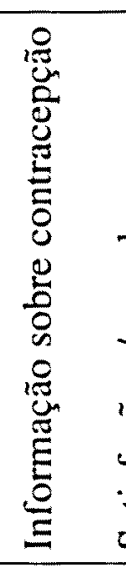 \\
\hline 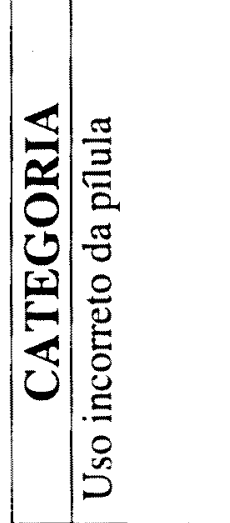 & 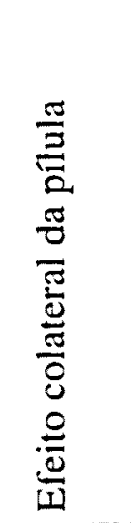 & 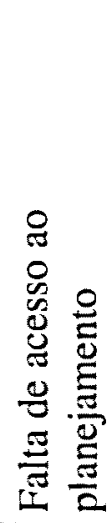 & 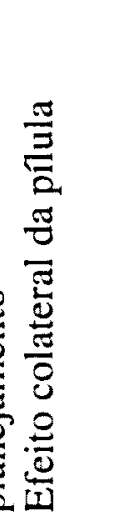 & 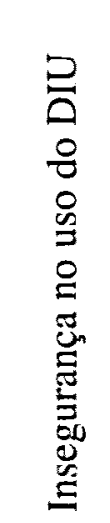 & 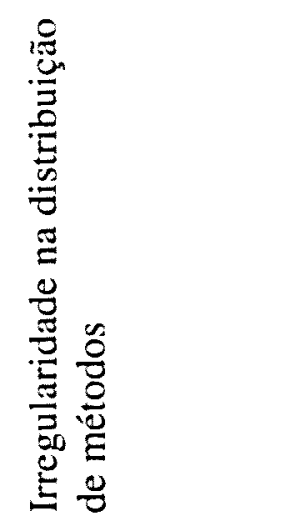 & 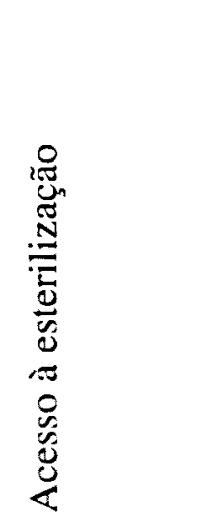 & 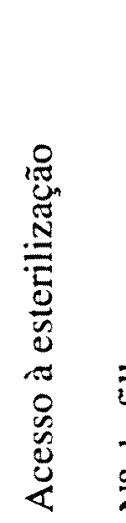 \\
\hline 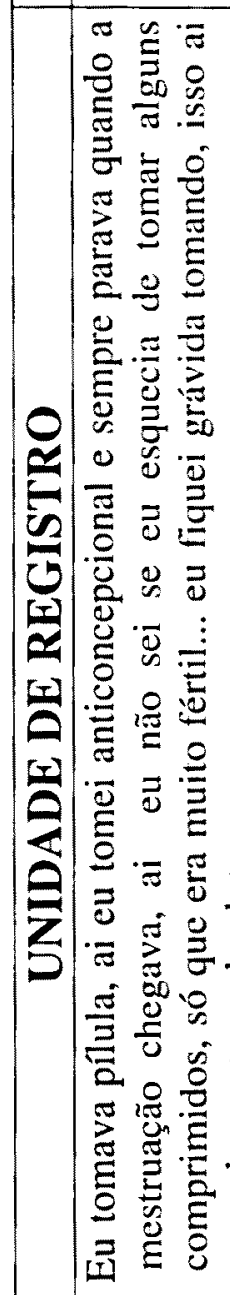 & 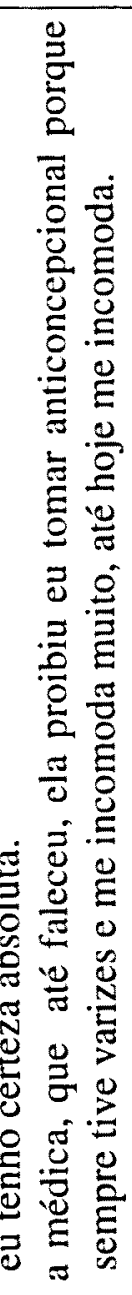 & 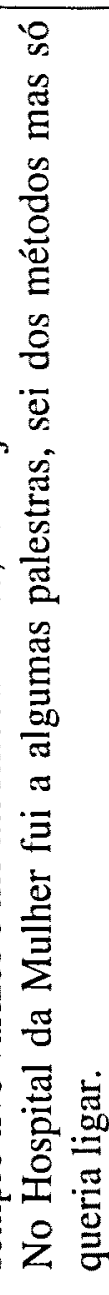 & 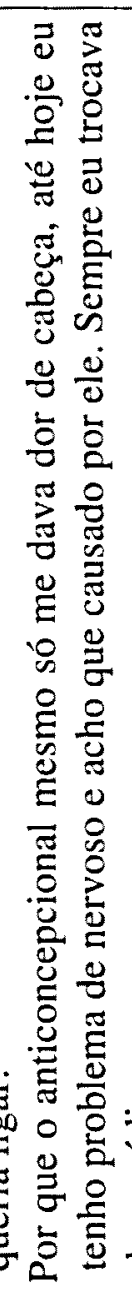 & 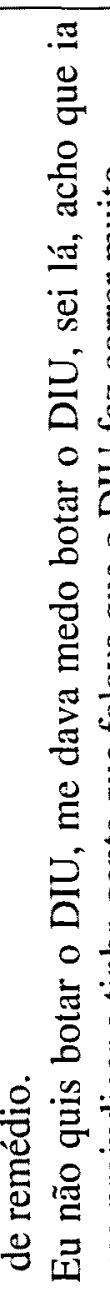 & 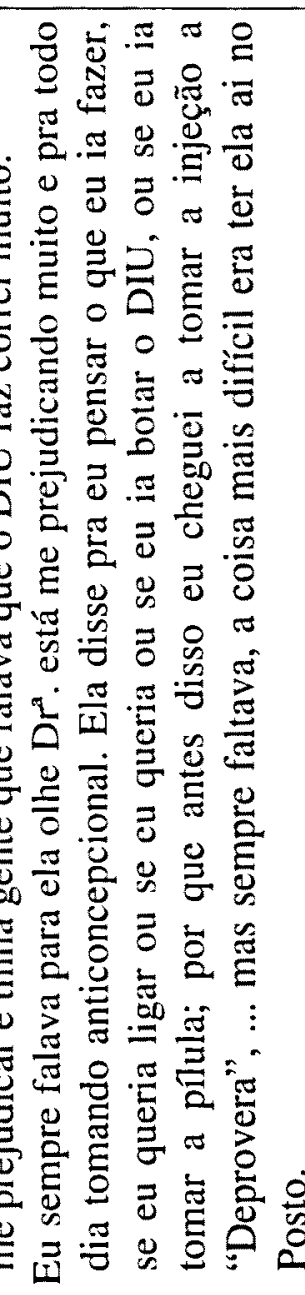 & 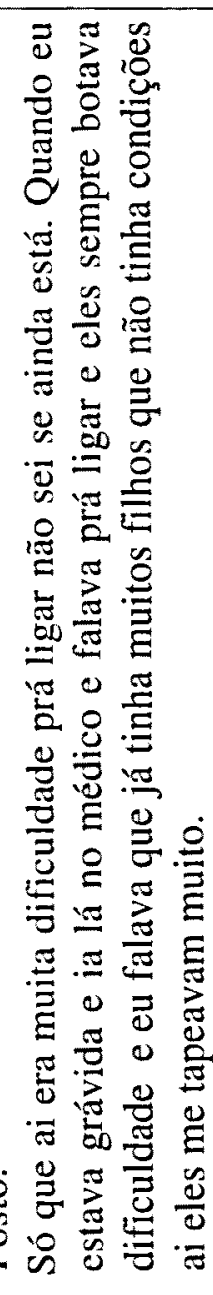 & 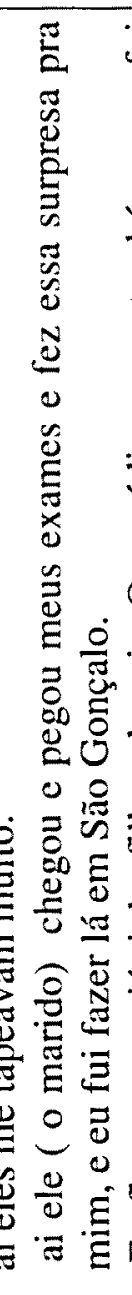 \\
\hline $\bar{\Xi}$ & $\stackrel{\sim}{g}$ & $\stackrel{m}{2}$ & $\stackrel{\ddot{g}}{\Xi}$ & $\stackrel{n}{2}$ & $\stackrel{0}{\circ}$ & $\hat{a}$ & $\stackrel{\infty}{\varrho}$ \\
\hline
\end{tabular}




\begin{tabular}{|c|c|c|c|c|}
\hline 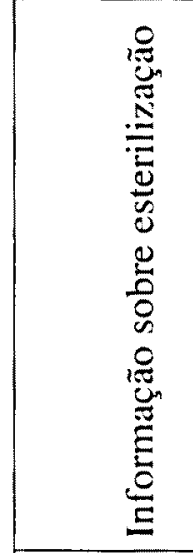 & 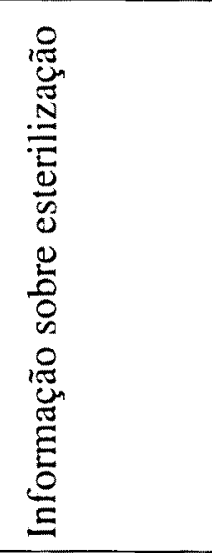 & 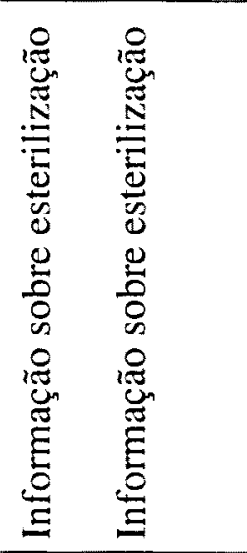 & 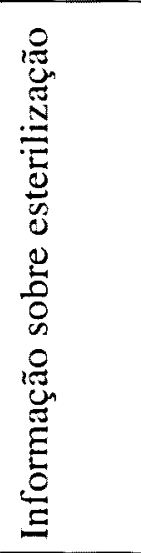 & \\
\hline 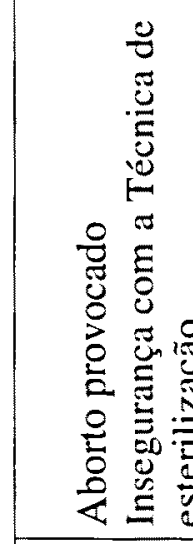 & 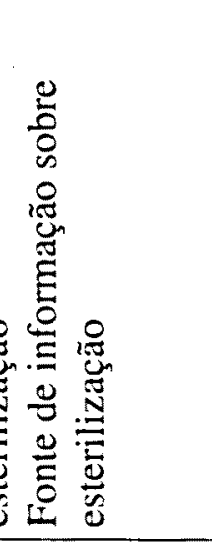 & 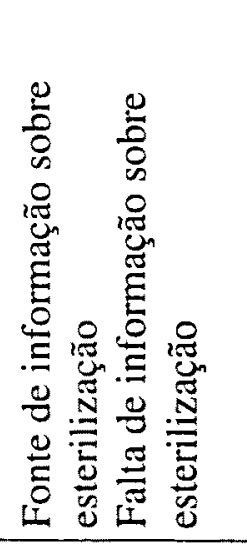 & 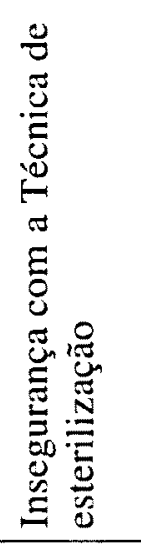 & \\
\hline 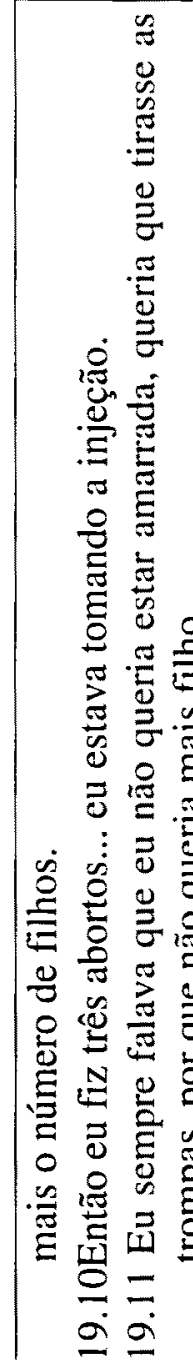 & 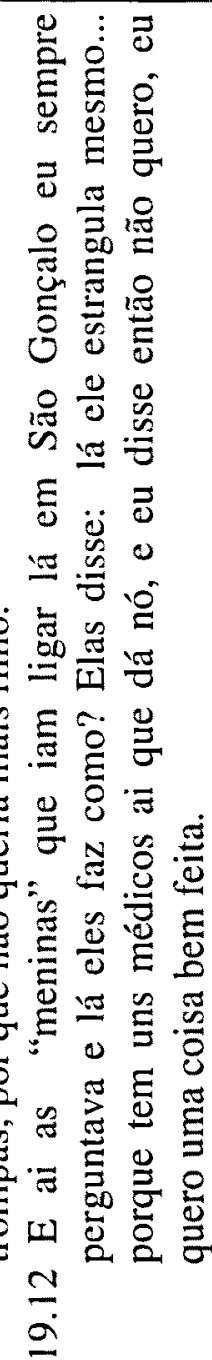 & 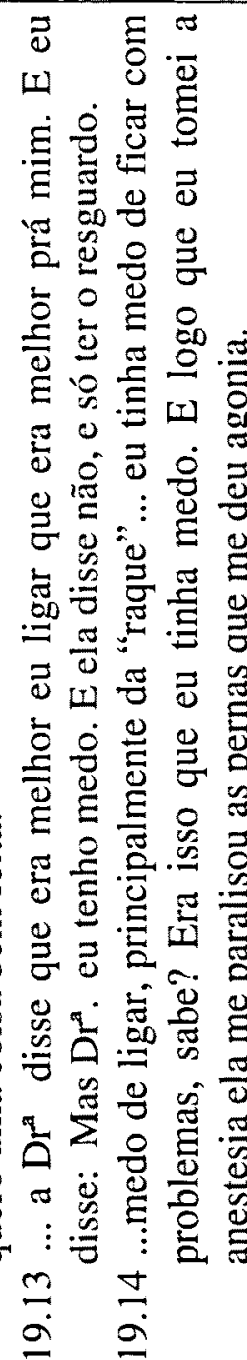 & 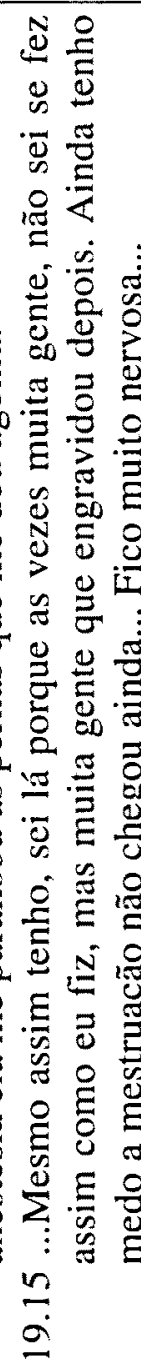 & 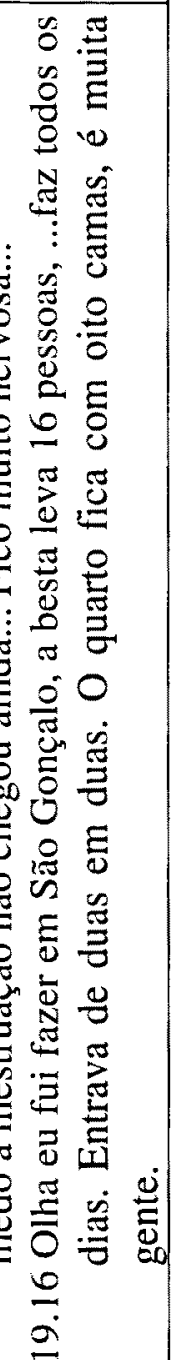 \\
\hline
\end{tabular}


in

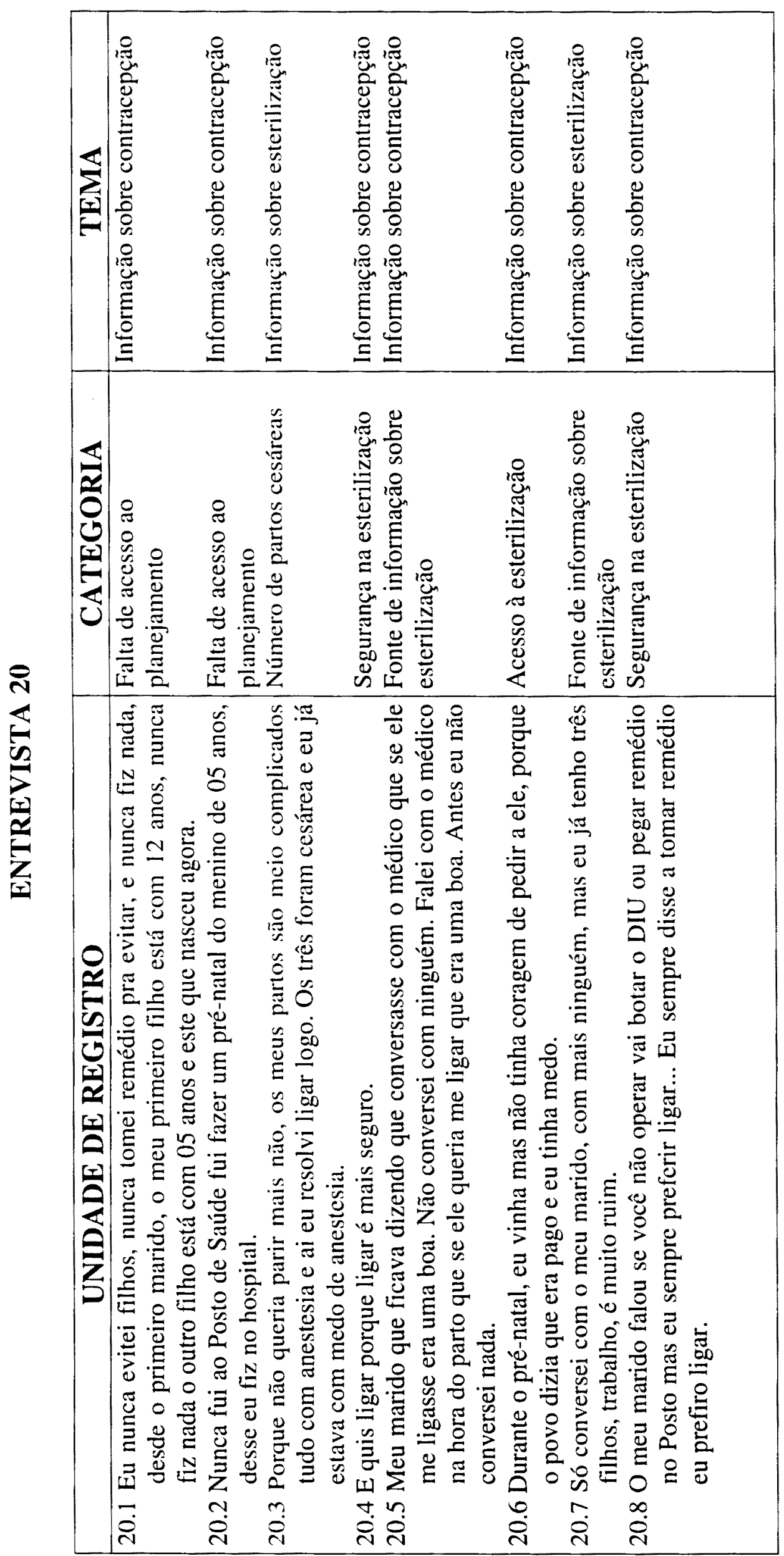




\section{ANEXO 5 - temas e categorias construídos a partir das unidades de registro}

\section{Tema I - Dificuldade no uso da pílula}

\section{Pilulas Inadequadas}

$1.2 \mathrm{O}$ anticoncepcional eu tomei, passei três anos tomando e por uma falha eu engravidei, acho que foi o remédio mesmo que já estava fraco.

2.3 Eu estava amamentando a menina e tomando o micronor, só que o micronor já estava ficando fraco e eu não mudei e ai engravidei.

\section{Falta de confiança na pílula}

1.8 Eu penso assim, se eu continuar tomando remédio um dia vai falhar

5.6 Era prá eu ficar com dois fillhos, o último eu peguei com remédio, esse neovular, a menstruação estava vindo antes de acabar o comprimido... Quando fica assim é que não estava dando mais

17.4Ai eu decidi a querer ligar, por que evita com remédio podia falhar também, né?

\section{Uso incorreto da pílula}

3.2 depois eu comecei a usar a pílula, só que eu era muito esquecida eu tenho 4 filhos e todos são frutos do esquecimento, eu esquecia mesmo. A gente tem o costume de dizer ah! a pílula falhou, mas não era que falhava era que eu realmente esquecia.

10.1 Eu tomava comprimido desde o primeiro... eu errava o horário ou o dia... a gente se esquece, aí aparecia grávida sem querer. Ai engravidei de cinco filhos, mesmo tomando pílula.

14.1 Tomava remédio, sempre tomei, eu engravidava porque não tomava o remédio certo...

16.1 Eu tomava remédio, mas não me dava e ai tomava dia sim dia não, até quando engravidei da primeira filha.

19.1 Eu tomava pílula, ai eu tomei anticoncepcional e sempre parava quando a mestruação chegava, ai eu não sei se eu esquecia de tomar alguns comprimidos, só que era muito fértil... eu fiquei grávida tomando, isso ai eu tenho certeza absoluta.

\section{Efeitos colaterais da pílula}

2.6 O médico falou para eu mudar que o remédio estava fraco, mas só que eu fiquei com medo porque os anticoncepcionais têm muito hormônio e eu fiquei com medo de passar para menina.

4.1 Eu logo quando casei comecei a tomar anticoncepcional, ai com dois anos e meio por ai eu parei porque tive um problema de inflamação, essas coisas ai eu parei o remédio.

4.3 Tive em novembro, quando foi em janeiro fiz revisão, ai já pedi o anticoncepcional pra tomar. Tomei durante onze anos, só que durante esse tempo começou a sair umas manchas vermelhas no corpo.

4.8 De um filho para o outro foram quase 12 anos tomando anticoncepcional... Agora 
o problema apareceu e eu fiquei quase 3 anos com esse problema tentando descobrir...

5.1 Sempre usei pílulas, ai comecei a usar aquele Microvilar, ai fiquei muito mal, comecei a emagrecer, perder o apetite ai passei a usar Nordete não senti bem também ai passei para Neovilar e tomei até antes de ligar. Resolvi parar não estava sentindo bem.

6.1 ... antes de engravidar do primeiro menino eu nunca tomei nada, tive ela e fiquei amamentando... fui ao médico e ele passou um remédio e disse que mesmo amamentando eu ia menstruar,.... depois comecei a tomar remédio de novo quando parei, eu tomava a "femina" ai comecei a sentir mal pressão baixa, ai o medico mandou parar um pouco,

6.9 Ele sugeriu, ir evitando, tomar o remédio mesmo, usar a camisinha, mas no meu caso não comecei a passar bem com as pílulas

12.1 Eu sempre usei remédio de evitar, o microvilar ai comecei sentir enjoou...suspendi por que o médico disse que minha pressão estava subindo muito.

13.1 Eu usava tabelinha, depois comecei a usar anticoncepcional, mas começou a me dar dor no estômago... o médico suspendeu e me falou para usar a camisinha, e fazer exame prá saber, e se é com todos os anticoncepcionais, porque algum anticoncepcional poderia não dar.

13.2 Ai eu mudei para um outro que era importado, e tinha lá no posto. Eu não senti dor, mas optei por não mais usar, por que não gosto e também por problema de pele, eu já tenho uma pele ruim (manchas) e o anticoncepcional é uma maravilha para manchar a pele ai parei e fiquei com a tabelinha.

15.1 No começo eu tomei pílula durante três anos, depois do primeiro filho, o filho mais velho tem 09 anos, o outro 8 e o outro 7, depois do de sete anos eu coloquei o DIU. Com a pílula eu sentia enjoou.

16.2 Tomava hoje amanhã não tomava por que vomitava, enjoava, com dor de cabeça e sentia mal, parecendo que ia desmaiar, ai fazia assim um dia tomava e outro não, ficava tomando assim achando que evitava filho... com a Segunda foi a mesma coisa, ai engravidei da segunda e disse: dessa daqui agora vou ter que ligar.

19.2 A médica, que até faleceu, ela proibiu eu tomar anticoncepcional porque sempre tive varizes e me incomoda muito, até hoje me incomoda.

19.4 Por que o anticoncepcional mesmo só me dava dor de cabeça, até hoje eu tenho problema de nervoso e acho que causado por ele. Sempre eu trocava de remédio.

\section{Falta de informação sobre uso da pílula}

5.2 Sempre usei por minha cabeça mesmo... Quando sentia que estava meio fraco o remédio eu ia trocando por minha cabeça.

14.4 O remédio eu comprava na farmácia não era passado por médico.

16.5tomava remédio por minha cabeça, não tive orientação de ninguém.

\section{Impossibilidade no uso da pílula}

9.2 E a pílula eu não posso tomar por que tomo gardenal, ai engravidei do neném. 


\section{TEMA II- MEDO DO DIU}

\section{Efeitos colaterais do DIU}

2.10 ...Falou também que eu podia usar o DIU, mas fiquei com medo porque geralmente as mulheres não se dão bem com o DIU e ai eu achei melhor não colocar.

3.13 Ah! Eu conheço o DIU, mas minha irmã teve um problema com o DIU e eu não quis.

8.5 Depois que eu tive a primeira filha minha mãe queria botar o DIU, só que minha mãe depois ficou com medo de botar o DIU e sair do lugar, e dá problema no meu útero.

9.1 Eu casei com 16 anos, logo engravidei do primeiro. Ai eu usei o DIU por 05 anos, aí o DIU ficou fora, ai minha família mandou botar de novo, ai eu não pude colocar por que eu estava perdendo muito sangue...

12.2 Botei o DIU... comecei a sentir também a menstruação vinha e saia os bolos, ai eu voltei ao ginecologista de novo e ele disse que eu não poderia usar o DIU, que estava inchando o meu útero, ai eu peguei e tirei o DIU,

14.9 tem gente que não se dá, aí eu não quis botar também.

15.2 Ai botei o DIU, depois não me dei também tirei, eu estava sangrando demais no período que botei o DIU, foram quatro anos e quatro anos de sangramento.

\section{Insegurança no uso do DIU}

1.9 Eu não queria usar o DIU,

4.9 Uma médica falou, porque você não para os remédios e faz o DIU prá ver. Mas eu já estava no pensamento de parar o remédio, e quando engravidei resolvi ligar.

6.10 Quando tive a menina, quiseram colocar o DIU..., só que me senti tão mal que eu fiquei com medo, mais uma dor, não quero não e já colocava no outro dia mesmo, aí não quis, ai depois tinha que ir para o planejamento familiar eu fui relaxando e passou. Mas já estava decidido se a médica não ligar eu vou colocar o DIU.

10.3 Ofereceram pra mim o DIU mas eu tinha cisma, sei lá, sinto que tenho uma aparelho diferente dentro de mim, e nunca usei não.

16.7 DIU eu tenho medo.

19.5Eu não quis botar o DIU, me dava medo botar o DIU, sei lá, acho que ia me prejudicar e tinha gente que falava que o DIU faz correr muito.

\section{Falta de informação no uso do DIU}

13.12 O DIU eu vou ter que controlar, aquela coisa de exame de 06 em 06 meses...

14.8 Ouvi falar em DIU, botar o DIU tem que está todo mês no hospital, 


\section{TEMA III- DIFICULDADE COM OUTROS MÉTODOS}

\section{Inadequação com a camisinha}

3.1 Primeiro usei camisinha, achava muito chato,

6.2 E fiquei usando camisinha, acho que nesse usar de camisinha deve ter falhado.

12.3 Aí levei três meses usando camisinha ai eu vi que não dava certo, ai eu fui e fiz o tratamento e liguei.

16.6 Eu sabia de outros métodos e não gostava e não gostava. Camisinha eu não quis,

\section{Inadequação com o coito interrompido}

3.14 Cheguei a fazer coito interrompido mas não deu.

\section{Inadequação com a tabela}

14.2 fiz tabela, também mas fazia errado também.

\section{Efeitos colaterais da injeção}

1.10 também não queria usar a injeção; porque a minhas colegas lá tem uma três que usam injeção e minha prima usa a injeção direto e sempre tem problema eu fiquei com medo ela sempre tem problema.

10.4 Camisinha eu nunca usei, tentei a injeção de 01 mês, mas eu menstruava duas no mês, ai tentei com a de 06 meses, custava até 20 e poucos reais, ainda tomei umas 03, mas menstruava no primeiro mês, ai voltei a tomar comprimido ai foi que decidi ligar.

\section{Irregularidade na distribuiçao de métodos}

12.10 Ao planejamento familiar eu fui quando usava anticoncepcional, eu fazia no posto de saúde, eu pegava o comprimido, e quando não tinha eles davam um, pra substituir o microvilar, foi quando eu comecei a sentir mal foi ai, por que começou a variar, e dizer que faz mesmo efeito, não se dava bem de jeito nenhum, ai eu que não tinha condições de comprar...

19.6 Eu sempre falava para ela olhe $\mathrm{Dr}^{2}$. está me prejudicando muito e pra todo dia tomando anticoncepcional. Ela disse pra eu pensar o que eu ia fazer, se eu queria ligar ou se eu queria ou se eu ia botar o DIU, ou se eu ia tomar a pílula; por que antes disso eu cheguei a tomar a injeção a "Deprovera", ... mas sempre faltava, a coisa mais difícil era ter ela ai no Posto. 


\section{TEMA IV-SATISFAÇÃO COM A PROLE}

\section{Numero de filhos}

1.3. Ai quando aconteceu eu deixei e pensei quando eu ter o segundo eu ligo.

1.5. Ai pensei do terceiro eu ligo não quero nenhum filho a mais.

1.6 Eu sempre pensava comigo, depois que - eu ter três filhos eu ligo.

1.7 Eu queria ligar por que eu só queria três filhos

$2.8 \mathrm{Ai}$ eu resolvi que devia ligar, eu já tenho dois filhos, crio um menino e ai eu falei três está bom demais.

11.1 Eu comecei minha vida sexual eu tinha 14 anos, minha filha tem 17 anos, quando ela nasceu eu comecei a tomar comprimido, eu evitei 03 anos, aí veio a $2^{\text {a }}$ que tem 14 anos passei mais três anos evitando ai veio a de 11 anos, evitei mais quatro anos e meio, o menino que tem 06 anos veio e continuei com a pílula, aí depois de 06 anos e continuei a pílula, ai depois de 06 anos veio esse nasceu está com 04 meses, ai eu resolvi ligar por que já estava com 05 filhos.

14.5 A ligadura, eu decidi por que sei não ficar só parindo, parindo ai disseram que aqui no hospital da mulher ligava, que o doutor ligava.

15.5 Por que eu tenho já quatro filhos e já estava demais né?

15.10 O que me levou a ligar mesmo foi a quantidade de filhos

16.8 Foi pelo número de filho, que a situação está difícil e a educação em primeiro lugar, e a vida hoje tá que tá, a gente tenta educar..

17.3 Por que muito filho e as condições né?

19.9 Eu fiz, por que já tinha filhos demais. O remédio pesou também, mas foi mais o número de filhos.

\section{Condições socio-economicas}

1.14 O meu marido gostou de eu Ter feito porque ele é uma pessoa casada e tem mais três filhos

2.7 Eu fiquei muito preocupada para tomar a vacina, na época meu marido estava praticamente desempregado, e eu criei medo de acontecer a mesma coisa com este, quando eu tivesse esse de tomar vacina que custa um salário mínimo ou mais, na época o salário era 131,00 e a injeção 143,00 mais de um salário né?

3.12 ... porque as coisas estão tão difíceis não é brincadeira prá gente pagar escola do jeito que as coisas estão e também hoje em dia com muitos filhos você não pode trabalhar.

4.5 Decidi por causa de minhas condições financeiras. Meu marido bebe, eu não tinha condições nenhuma de ter, eu já estava desempregada.

6.6 E tudo isso, a vida está tão difícil, prá três fillhos. Quando eu engravidei dela eu parei de trabalhar por que eu trabalhava autônoma vendendo cosméticos.

7.3 Porque não queria mais filho, sei lá por causa das condições também, não é? Com muito filho não dá, também as condições hoje são muito precária... Eu não queria mais filho mesmo, o sofrimento é muito grande.

10.6 Ah eu pensei que eu tinha muitos filhos e eu não tinha condições de criar mais de 
cinco e já estava na idade avançada prá eu ainda ter mais filhos. Eu tenho três filhos indesejados, eu não planejei.

11.6 ...Pensei que já tinha 05 filhos e não valia mais a pena engravidar. E hoje em dia está tão difícil da conta de 05 fillhos pra dar estudo pra dar de tudo. Pensei, acho que não estou pecando não por que eu vou ligar não.

12.5 ... por que quando entrei logo para o PACS, disseram: Ah! Se engravidar você perde o emprego. Ai eu fiquei com medo, porque era recente e o que eu mais queria era esse trabalho.

12.7 Minha preocupação era não perder o emprego ai eu peguei logo e liguei. Eu tinha medo de perder emprego. Eu queria muito esse trabalho porque eu lutei tanto para Ter ele e perder assim através de um filho, eu peguei e liguei.

13.5 Como eu já tinha 3 filhos eu achei que eu poderia fazer, por que prá que mais de três filhos no mundo de hoje né?... eu não tenho situação tão equilibrada assim, eu faço da vida gato e sapato prá conseguir.

16.3 por que já tem dois com ele (marido) e mais dois só dele, inteirava quatro, e as condições de vida, a educação do filho é coisa muito difícil pra poder criar os filhos, então foi desse jeito que eu arrumei um jeito de ligar logo, pagar prá poder ligar.

18.3 Ah, porque eu trabalho... minha mãe já fica com a menina, ai com mais esse agora, é muito trabalho pra ela, aí eu disse é melhor eu ligar por que não tem condições de estar pagando ninguém pra tomar conta.

\section{TEMA V- INFORMAÇÃO SOBRE CONTRACEPÇÃO}

\section{Falta de acesso ao planejamento familiar}

1.12 Eu já tinha conversado com o médico para ele fazer e depois que tive o neném fui lá ele marcou prá fazer... não passei no planejamento do hospital.

2.5 Nunca freqüentei o Serviço de planejamento familiar as vezes o médico passava as pílulas e as vezes eu comprava na farmácia.

3.5 Só fui duas vezes no planejamento familiar, e não fui mais, também não tinha tempo, eu trabalhava.

6.3 eu fui no médico e ele passou mas nunca freqüentei o planejamento familiar não.

7.6 Há muito tempo atrás, eu fui ao planejamento familiar uma vez no posto, assisti uma palestra, era para colocar o DIU, mas eu desisti e não voltei mais.

9.6 Só fui no planejamento familiar para botar o DIU e não fui mais.

10.2 Teve uma época que eu freqüentei o planejamento, no posto, mas como tinha menino pequeno era difícil de ir eu passei a comprar o remédio.

11.7 Nunca fui ao planejamento. Conhecia outros métodos mas confiava mais no comprimido por que nunca senti nada.

14.3 Nunca fui ao planejamento familiar.

15.3 Fui ao planejamento familiar do hospital. Eu conhecia todos os métodos.

16.4 Nunca fui ao planejamento familiar

17.2 Nunca fui ao serviço de planejamento familiar. Nunca procurei. Fiz o pré-natal de todos, as pessoas falavam mas eu nunca liguei.

18.2 Fui ao Planejamento Familiar uma vez no posto, lá onde eu trabalhava também 
tinha sempre palestra ai eu achava melhor ligar porque não queria filho mesmo. Eu conhecia todos os métodos, da camisinha, injeção, DIU, isso tudo, mas eu achava melhor pra mim o remédio.

19.3 No Hospital da Mulher fui a algumas palestras, sei dos métodos mas só queria ligar.

20.1 Eu nunca evitei filhos, nunca tomei remédio pra evitar, e nunca fiz nada, desde o primeiro marido, o meu primeiro filho está com 12 anos, nunca fiz nada o outro filho está com 05 anos e este que nasceu agora.

20.2 Nunca fui ao Posto de Saúde fui fazer um pré-natal do menino de 05 anos, desse eu fiz no hospital.

\section{Informação equivocada}

2.1 Eu tomava anticoncepcional, e ai eu parei para engravidar, engravidei duas vezes e perdi por causa do meu tipo de sangue que é negativo, eu não sabia...

2.4 ... Resolvi ligar foi justamente por causa do sangue, cada vez que eu tivesse um filho tem que tomar a vacina né?

2.9 Conversei com a enfermeira que fazia o meu pré natal, ela achou que justamente por causa do meu tipo de sangue a melhor maneira de evitar era ligando.

4.4 ... No ano passado eu tive uma dor... Era que os comprimidos acumularam na trompa, então foi preciso tirar... tiraram a trompa esquerda e o ovário esquerdo... No início na ultra suspeitaram de gravidez nas trompas, mas quando o médico abriu e tirou não foi filho não. Agora como eles ficaram lá dentro eu não sei.

6.4 A ligadura eu decidi por que desde que eu tive a primeira menina a médica disse que eu não tinha condições, de ter parto normal porque tinha o colo muito fechado... Ai também eu tenho sangue negativo

9.3 Por que o médico do pré-natal disse que eu já devia ter ligado que eu não podia ficar engravidando não por causa dos meus problemas... Que é melhor ligar do que fica parindo todo ano...fez cesária e ligou.

$11.4 \ldots$ o médico veio e ai falou que eu não podia mais ter filho, e me explicou que eu tinha tido eclampsia e se eu tentasse engravidar de novo, se não perdesse o bebê no começo da gravidez, eu não chegaria aos 7 e se chegasse eu teria crises e quando o bebê nascesse ia nascer com problema aquilo deu muito medo.

11.5 eu fiquei com medo do bebê morrer e ficar sempre com aquele sonho, e se eu ficasse como eu estava, tinha chance de fazer um tratamento e ter outro filho, ai sim eu poderia ligar e assim fiz,

\section{Acesso à esterilização}

1.15 Agora se fosse prá fazer com os políticos e eu não fazia não é tudo nas carreiras.

3.6 Desde a $2^{a}$ filha eu pensei em ligar, mas sempre que eu procurava, o posto de saúde, tinha aquela dificuldade... Não podia ligar, por que ainda estava cedo e sempre aquela dificuldade... então falei com o médico: “ô Dr. Eu preciso eu já tenho a Quarta filha e eu preciso ligar "e ai eu conversei com uma amiga que trabalha no hospital que eu liguei, e ai ela ajeitou lá, e eu fui na palestra duas vezes lá, e o termo de responsabilidade meu marido assinou. 
12.6 ... ai falei vou ligar, ai o pessoal veio, e falou se você quiser ir, você vai ligar, ai eu encaminhei os exames e fiz a ligadura. Fui, viajei e me liguei lá em São Gonçalo.

15.10Ai a menina veio aqui comigo marcou, eu assinei e ai vim me internar, ai fizeram a cesárea e ligaram.

16.9 Ai fiz cesárea pela SUS, e paguei prá ligar.

16.10Acertei tudo na hora... Eu pedi ao médico até pelo amor de Deus prá me ligar. Ai ele disse: seu marido já acertou tudo comigo

19.7 Só que ai era muita dificuldade prá ligar não sei se ainda está. Quando eu estava grávida e ia lá no médico e falava prá ligar e eles sempre botava dificuldade e eu falava que já tinha muitos fỉlhos que não tinha condições ai eles me tapeavam muito.

19.8 ai ele ( o marido) chegou e pegou meus exames e fez essa surpresa pra mim, e eu fui fazer lá em São Gonçalo

20.6 Durante o pré-natal, eu vinha mas não tinha coragem de pedir a ele, porque o povo dizia que era pago e eu tinha medo

\section{Segurança na esterilização}

3.3 voltei a usar a camisinha novamente, e ai disse: "olha é melhor eu ligar porque pelo menos eu ligo e fico livre, e não fica essa preocupação de tomei não tomei, e ai resolvi ligar".

4.6 ... e também pelo medo, eu já estava com esse problema e não sabia se eu ia continuar tomando remédio... Ai conversei com o meu médico e resolvi ligar por causa disso.

5.4 ... não ia esperar para ter mais filho não, e ficar tomando comprimido eu não ia querer mais nem botar DIU, queria ligar mesmo.

6.7... Desde que eu tive o menino (2) que eu já ia ligar... também na época eu estava muito nova, agora eu acho que ainda estou nova, prá ligar mas a médica optou porque não tenho mais condições de Ter mais outro e prá não correr o risco, ela achou melhor ligar.

7.5 Mesmo tendo usado pílula 11 anos eu queria ter certeza que não ia engravidar mesmo. Só ligada que eu tinha certeza.

13.11 No início do pré-natal, eu nem pensava que ia ligar, só no final mesmo quando fiquei certo que ia fazer cesárea foi que ficou definido é que eu decidi. Eu vou ligar por que também acaba essa história de controle, que eu não posso tomar comprimido,

14.10.A ligadura eu acho mais seguro.

17.5 Aí eu falei o certo vai ser ligar mesmo. Nunca usei remédio mas achei que podia falhar e ligar é mais seguro.

18.4 Só queria ligar, por que dois filhos pra gente educar é mais fácil... o único método que me dava certeza que eu não ia ter mais filho era ligar.

20.4 E quis ligar porque ligar é mais seguro.

20.8 O meu marido falou se você não operar vai botar o DIU ou pegar remédio no Posto mas eu sempre preferir ligar... Eu sempre disse a tomar remédio eu prefiro ligar 


\section{TEMA VI- INFORMAÇÃO SOBRE ESTERILIZAÇÃO}

\section{Falta de informação sobre esterilização}

1.13 Mas eu queria que um profissional chegasse pra mim e explicasse como é esse negócio de ligação

2.11 Ai o médico disse: é uma decisão sua e ai programou para fazer o parto.

3.7 Não, a única coisa que eles me perguntaram é se eu tinha consciência do que eu estava fazendo, se meu marido concordava, que eu tinha de assinar um termo de responsabilidade, e meu marido também, e só poderia ligar se meu marido assinasse.

3.8 Se tinha assim algum perigo, alguma coisa, não foi passado prá mim, as consequências, eles não passaram.

3.9 Porque também eu nem culpa ninguém lá eu culpo a mim mesmo, porque eu não fui fazer o planejamento, só fui a duas palestras a pulso, com certeza eles dizem tudo nas palestras.

8.2 ... Ai no dia da ligação eu fiquei com medo. Todo mundo diz que dá mioma, que dá problema na cabeça no lugar que liga, ai eu fiquei com medo ai eu falei não vou ligar, não vou, não vou.

8.4 Não perguntei nada, ninguém falou nada ai eu liguei, não senti nada, só dor de cabeça, porque fiquei muito nervosa, eu tomei muito soro, porque eu estava de anemia.

10.5 Eu tinha muito medo de ligar por que eu nunca fiz uma cirurgia e tinha muito medo da anestesia, ai eu ainda marquei com o político em 92 , do $2^{\circ}$ menino. Ai quando o carro me pegou aqui prá levar pra São Gonçalo eu fiquei com medo, não fui.

10.7 Não, não tinha orientação de ninguém... eu via as outras fazendo e não paria e eu também queria parar de parir...

10.9 Mas eu tinha muito medo da cirurgia e anestesia tinha medo de morrer ou ficar aleijada. Tem horas que fico pensando que nem liguei por que a coragem eu digo que foi Deus que me preparou para não ficar nessa preocupação por que já ter cinco filhos e sem condições boas.

12.12 Eu fui com bastante medo, tinha medo de morrer!... por que o pessoal me metia medo também, que muitas morriam, que a anestesia "raque" se não tomasse cuidado ia ficar paraplégica, eu ficava com medo, mas, eu fui (risos) mas ai eu fui mesmo!

13.6 Agora, com relação a ligadura eu acho que devia ter, existir, uma diálogo maior do médico e a paciente porque é uma decisão pra sempre né. Eu acho que o médico deveria assim antes de levar o paciente prá o soro, deveria sentar um pouco, conversar... perguntar...

13.8 Mas, continuo achando que é pouca informação à respeito da ligadura. Mas tem gente que liga com dois filhos e até com um não é? É perigoso, eu que tenho três depois que eu liguei deu tipo assim, quase um arrependimento.

13.10 A maioria das pessoas que conheço que fizeram ligaduras, eu acho elas muito pouco esclarecidas, são donas de casa, pessoas assim de mais idade não são pessoas assim que poderiam conversar, elas só falavam assim a injeção da coluna dói muito, e depois dói demais, dói demais e nem sequer falam que pode arrepender de querer ter filhos. 
15.7 Ninguém falou de arrependimento. Todas minhas amigas que já tinha feito me incentivou.

15.8 Eu só tinha medo da anestesia eu tinha medo de ficar aleijada todos os meus partos foram normais.

17.6 Conversei no hospital, antes não conversei com ninguém, não fiz pré-natal não, só na hora de parir é que decidi. Eu cheguei no hospital aí uma moça falou assim: Por que você não liga, você já tem filho demais, eu falei não vou ligar não.

19.14 ...medo de ligar, principalmente da "raque"... eu tinha medo de ficar com problemas, sabe? Era isso que eu tinha medo. E logo que eu tomei a anestesia ela me paralisou as pernas que me deu agonia

\section{Número de cesáreas}

5.3 Por que com três partos cesariano né, eu não ia tentar que é mais perigoso.

6.5 Decidi também por que três cesarianas, depois de três ninguém tem condições de fazer mais uma cesariana.

20.3 Porque não queria parir mais não, os meus partos são meio complicados tudo com anestesia e ai eu resolvi ligar logo. Os três foram cesárea e eu já estava com medo de anestesia.

\section{Fonte de Informação sobre esterilização}

1.11 Minhas duas colegas e duas primas e duas irmãs que ligaram não sentem nada, já outras disse que tinha problemas depois que ligou, dor nas pernas, dor na barriga tantas coisas..

2.12 O médico me disse que eu podia me arrepender, e eu disse a ele Jesus não ia deixar eu me arrepender.

4.7 ... durante a gravidez eu conversei muito com minha médica, sobre os problemas que enfrento.

5.7 Tomei a decisão e quis ligar, o médico que fez meu parto na hora perguntou quantos filhos eu tinha. Eu disse que tinha três cesarianas e não queria filho mais não. Ele me perguntou se eu não queria esperar o menino, eu disse não... fez a cesárea prá poder ligar, poderia até ser normal, mas eu ia ligar por que é um resguardo só.

6.8 Desde que eu tive o menino o médico me falou, aquele doutor..... do CEPAR, ele falou olha mãe, prá ligar devido ao seu problema de não ter normal, pode ser só que você está muito nova, e se você ligar agora corre de mais tarde você ter problema de hemorragia, e outras coisas então é melhor você espere mais um pouco para chegar aos 29 ou 30 anos.

7.2 A médica me explicou, perguntou se eu queria isso mesmo, falei que queria.

7.4 ... a médica disse prá eu pensar bem prá não me arrepender, prá conversar com meu marido. Mas ele aceitou tudo e a médica me explicou tudo, também disse que depois de ligar não tem mais condições de ter filho... toda vez que eu vinha ela falava e perguntava se era isso mesmo que eu queria, que eu só tinha um filho. Acho que ela estava meio assim sem querer fazer.

$12.8 \mathrm{Não}$, ninguém conversou não, sempre os colegas né? E o doutor quando foi me ligar falou: "você tem $50 \%$ de pegar cisto no ovário"... " Cisto no ovário e ter 


\section{menstruação demais.}

12.9 ... Ele não falou de arrependimento, só falou se agente queria mesmo ligar, se era aquilo que a gente queria.

13.7 Não, eu vim fazer a cesárea e disse que ia fazer a cesárea e ligar também. O médico só me perguntou quantos filhos eu já tinha, que idade eu já tinha, e por que eu queria fazer.

14.7 As colegas falavam que prá ligar tinha que fazer cesárea, que se não fizesse cesárea eles não ligavam, tinha que fazer outros exames prá poder ligar. Ninguém mais conversou.

15.4 Através do médico, mas a decisão foi minha mesmo, porque pensei que ia ficar engravidando direto, prá que?

15.6 Conversei com minha comadre que é "enfermeira" e com o próprio médico... Só que ele marcou quatro vezes e eu fiquei com medo, só que depois... tinha medo da anestesia... eu fiz parto normal e depois liguei pelo umbigo.

15.9 Fiz pré-natal com o médico, eu conversei com ele e ele disse já que você quer ligar vamos.

17.7 Quando entrei que o médico foi fazer o toque eu falei assim: eu queria sair daqui ligada, ele falou assim: "com um mês a senhora volta, e eu disse eu não quero com um mês não, pode ser que eu não venha. Então ele disse quando a senhora sair daqui a senhora já sai ligada. Ai eu liguei. Decidi e fiz.

18.5 Conversei lá na firma com a enfermeira... Ela também falou no caso de um dia se eu quisesse mais filho, já sabe que não vai poder ter mais. Mas eu não me arrependo não, eu queria ligar mesmo.

19.12 E ai as "meninas" que iam ligar lá em São Gonçalo eu sempre perguntava e lá eles faz como? Elas disse: lá ele estrangula mesmo... porque tem uns médicos ai que dá nó, e eu disse então não quero, eu quero uma coisa bem feita.

19.13 ... a $\mathrm{Dr}^{\mathrm{a}}$ disse que era melhor eu ligar que era melhor prá mim. E eu disse: Mas $\mathrm{Dr}^{2}$. eu tenho medo. E ela disse não, e só ter o resguardo.

20.5 Meu marido que ficava dizendo que conversasse com o médico que se ele me ligasse era uma boa. Não conversei com ninguém. Falei com o médico na hora do parto que se ele queria me ligar que era uma boa. Antes eu não conversei nada.

20.7 Só conversei com o meu marido, com mais ninguém, mas eu já tenho três filhos, trabalho, é muito ruim.

\section{Sintomas após esterilização}

12.13 Só sinto mesmo, que eu não sentia é cólica. Eu não sentia cólica... Hoje quando está perto de vir, 03 dias antes é uma cólica... e quando está perto de ir embora também é uma cólica muita cólica mesmo, e minha menstruação redobrou, corre demais, corre demais mesmo, parece até que é hemorragia.

\section{Insegurança com a técnica de esterilização}

3.10 ... Eu também achei condição de ligar fora mas eu não queria porque tenho muito medo dessa ligação, e aquele negócio de um monte de gente rápido e de repente 
todo mundo já ligou e já voltou, e eu ficava pensando: "será que essa ligadura é segura?"

3.11 Eu não quero mais engravidar. Eu conheço pessoas que... no dia mesmo que eu fui, tinha 2 mulheres lá que eram ligadas e que estavam grávidas.

5.5 ... eu até falei com o médico na hora eu quero "estrangular", ele até não gostou. Disse que o médico era ele e que era para não ficar perguntando nada não se ligou não... Mas eu tenho minhas dúvidas ainda se ele estrangulou viu, ele não mostrou nada... Se eu voltar a ter outro filho o negócio vai pegar viu?

19.11 Eu sempre falava que eu não queria estar amarrada, queria que tirasse as trompas, por que não queria mais filho.

19.15 ...Mesmo assim tenho, sei lá porque as vezes muita gente, não sei se fez assim como eu fiz, mas muita gente que engravidou depois. Ainda tenho medo a mestruação não chegou ainda... Fico muito nervosa... Olha eu fui fazer em São Gonçalo, a besta leva 16 pessoas, ...faz todos os dias. Entrava de duas em duas. O quarto fica com oito camas, é muita gente.

\section{TEMA VII- OUTROS}

\section{Parto difícil}

4.2 A gravidez foi ótima mas o parto...

11.3 Resolvi ligar por que já tinha 05 filhos,... tive 03 partos complicados o outro eu quase morro.

13,4 Como eu tinha tido uma parto muito difícil, que ele quase morreu... nasceu todo laçado a médica quebrou a clavícula... Eu ai fiquei traumatizada de ter filho natural ai eu decidi que outro filho que eu tivesse eu ia fazer cesárea, nesse período eu pensei, já que eu vou fazer cesárea eu vou ligar.

18.6 ... eu acho minha gravidez muito ruim, pois logo no começo da gravidez eu fico sangrando, esse mesmo foi de oito meses. O primeiro filho que morreu foi de sete meses... Eu tinha muito medo de parir a hora da dor, o medo de não parir logo de sofrer muito...

18.7 ... eu demorei muito de ter o menino, eu sofri muito, me colocaram no soro, eu pensei que ia morrer, eu gritava tanto, ... eu sofri demais, demais, foi tanto que tive até problema respiratório.

18.8 E também eu não gostei do atendimento, acho que lá eles maltratam muito as pessoas por isso tinha medo de ter filho por causa disso. Ai eu pensei não quero mais filho eu vou ligar. Ai eu fui e liguei.

\section{Falta de colaboração do companheiro}

6.11 Depois a gente viu o meu marido disse que ia fazer a vasectomia, mas aquela coisa de homem sabe como é não é? 


\section{Pressão familiar}

8.1 Eu nunca tomei remédio, eu tive a primeira menina, e teve muita confusão com meus pais... Ai apareci de barriga dessa menina (que tem 4 meses)... Ai minha mãe acertou a ligação prá mim.

8.3 Ai minha mãe falou se tu não ligar tu pega a menina e vai pró meio da rua, e eu disse: vou prá rua mais não vou ligar. Ai ela falou assim, é bom prá tu, porque tu pode trabalhar e não vai parir mais. A minha mãe acertou, e eu liguei.

9.4 A minha família que mandou e eu não podia falar nada, fiquei quieta. $\mathrm{O}$ meu marido aceitou. Eu só pensei que o meu problema ia piorar ligada.

9.5 A médica conversou, ela disse que se eu ligasse nova demais mais tarde poderia ter problemas disse que eu podia usar o DIU de novo, ai minha família me botou pra ligar e eu não podia fazer nada, fiquei quieta.

\section{Pressão social}

10.8 Também as pessoas diziam Ah! Hoje em dia pari quem quer, tem ligadura tem como evitar tem tudo, a gente fica parindo fica com vergonha. Mas dizem assim "existe remédio pari por que quer, eu não, eu não tenho pena de uma mãe cheia de filho" ai a gente se sente humilhada.

\section{Aborto provocado}

12.4 Só tenho um filho, tive um e um aborto, depois do aborto que eu liguei. Meu tem seis anos.

13.3... durante $01^{\circ}$ casamento eu tive um aborto... eu não estava bem com meu marido e não queria o filho... ai tomei o citotec... Ai acabei abortando, fui parar no balão de oxigênio e fiz a curetagem, depois disso eu passei a me cuidar mais a ter mais cuidado.

19.10. Então eu fiz três abortos... Eu estava tomando a injeção 